\title{
Gênese e Controles da Mineralização Secundária de P, Ti e ETR no Complexo Alcalino Carbonatítico de Salitre, MG
}

\author{
DISSERTAÇÃO DE MESTRADO \\ No 341
}

Ivan Mendes Caixeta de Pamplona Araújo

Orientador: José Affonso Brod

Brasília, 2015 


\title{
Gênese e Controles da Mineralização Secundária de P, Ti e ETR no Complexo Alcalino Carbonatítico de Salitre, MG
}

\author{
Ivan Mendes Caixeta de Pamplona Araújo
}

Área de Concentração: Prospecção e Geologia Econômica

Orientador: José Affonso Brod

\author{
Membros da Banca Examinadora \\ José Affonso Brod \\ Claudinei Gouveia de Oliveira \\ Reiner Neumann \\ Suplentes: \\ Cesar Fonseca Ferreira Filho \\ Carlos Cordeiro Ribeiro
}


"God is in the details," Levine once reminded him. "Maybe your God," Malcolm shot back. "Not mine. Mine is in the process."

Michael Crichton, The Lost World 


\section{Agradecimentos}

Obrigado a todos que de alguma forma contribuíram para a execução e finalização deste trabalho.

A meus pais, pelos ensinamentos e valores e pelo apoio incondicional em todos os aspectos da minha vida. Pela educação pautada em ética e caráter. Principalmente por me ensinarem a ser uma pessoa transparente comigo mesmo e com os outros. Aos meus irmãos, meus grandes amigos e parceiros, por me fazerem sentir como o irmão mais novo às vezes.

Ao Professor Affonso Brod, pela acolhida, orientação, amizade e hospitalidade, desde os tempos de iniciação científica. Por proporcionar a mim e a outros alunos e profissionais a oportunidade de pertencer a um grupo de pesquisa tão prolífico e estimulante quanto o GRAMA. À Tereza Cristina Junqueira-Brod, pela amizade e por me ensinar a importância do método cientifico. Por me inspirar a ver a beleza nos processos geológicos, independentemente de sua origem. A ambos, por constituírem minha segunda família: minha família científica.

À Vale Exploração pelo acesso às amostras e em especial à equipe de campo do projeto ETR-Salitre (Ingrid Brandão, Denise Rocha, Luiz Carlos Domingues, Luciana Melo e Reginaldo Cardoso) pelas discussões e apoio. Obrigado também à equipe do Centro de Desenvolvimento Mineral em Santa Luzia, principalmente Ângela Avelar, Renata Paula, Geraldo de Pádua e Jeová Souza, pelo suporte e acesso aos equipamentos, laboratórios e preparação de lâminas.

Agradeço especialmente à equipe de planejamento estratégico da Exploração Global Vale: Alysson Rajão, Juliana Faria, Patrícia Coutinho e Aline Matozinhos. Pela amizade, companheirismo, suporte e paciência durante minha ausência para a execução deste trabalho.

E por fim agradeço minhas mentoras, chefes, musas e parceiras: Jéssica Beatriz Carvalho e Elisabeth Fonseca. Pela inspiração, amizade, cumplicidade e por todas as conversas e discussões técnicas. Mas principalmente, obrigado pela acolhida. E por me deixarem fazer parte de suas equipes. 


\section{Resumo}

O complexo alcalino-carbonatítico de Salitre I, II e III, na Província Ígnea do Alto Paranaíba (APIP), é composto por múltiplas intrusões onde predominam bebedouritos, com diques anelares de carbonatitos e foscoritos subordinados. Sobre o complexo se desenvolveu um espesso manto de intemperismo que alterou a rocha original e propiciou a remobilização e concentração de fosfato, titânio e elementos terras raras (ETR) em teores econômicos. A partir de sondagem exploratória sobre a porção bebedourítica do complexo de Salitre I, o horizonte de alteração intempérica do depósito e a mineralogia associada à mineralização secundária são descritos em detalhe.

O perfil de intemperismo de Salitre I, como em outros depósitos da APIP, pode ser dividido em rocha fresca, rocha alterada, isalterita e aloterita, a partir de observações macroscópicas e de campo. Neste trabalho a designação rocha fresca indica rocha não intemperizada, independentemente da existência ou não de alteração metassomática prévia. Estudos mineralógicos e texturais em lâminas delgadas polidas obtidos por microscopia ótica e eletrônica associados a análises de rocha total e química mineral indicam que esta divisão se reflete na textura do manto de intemperismo e sua mineralogia.

A rocha fresca é composta por olivina-bebedouritos e perovskita-bebedouritos com diferentes graus de metassomatismo causado por intrusões de cálcio e magnesiocarbonatito. Dentre outras feições, a alteração metassomática resulta na neoformação de carbonato e magnetita, alteração de silicatos magnesianos primários (olivina, diopsídio, flogopita) para tetraferriflogopita, e conversão de perovskita para anatásio. Cumulados foscoríticos ricos em flúor-apatita também são observados no intervalo de rocha fresca das sondagens estudadas.

O horizonte de rocha alterada é caracterizado pelo aparecimento de precipitações de óxidos-hidróxidos de ferro no contato entre os grãos de carbonato e perda de potássio em cristais de flogopita e tetraferriflogopita.

No horizonte isalterítico o carbonato é completamente lixiviado e ocorre a concentração residual de minerais resistentes ao intemperismo, bem como a precipitação de apatita secundária como agregados cristalinos nas fraturas da apatita ígnea. Este horizonte pode ser dividido em isalterito micáceo de base (manutenção da morfologia dos cristais de flogopita, mesmo quando está alterada para vermiculita), micáceo de topo (rico em argilas do grupo da vermiculita, com óxidos-hidróxidos de Fe subordinados) e oxidado (rico em 
óxidos-hidróxidos de ferro, com argila subordinada). Em direção ao topo a perovskita apresenta progressivamente maior intensidade de alteração para anatásio supergênico, frequentemente associado com palhetas de monazita secundária.

No horizonte aloterítico a apatita não é mais estável, sendo substituída por fosfatos secundários do grupo da crandalita, e a perovskita está completamente alterada para anatásio. Este horizonte é dividido em aloterita de base (grande volume anatásio e monazita em meio a óxidos-hidróxidos de ferro) e aloterita de topo (rica em caolinita e gibbsita).

Análises químicas totais refletem a mineralogia descrita, e os horizontes de alteração apresentam assinatura geoquímica similar à rocha original. Teores de ETR tendem a se intensificar de forma progressiva até a aloterita de base. A mineralização de fosfato resulta principalmente da concentração residual de apatita primária dos bebedouritos e foscoritos no horizonte isalterítico, com apatita secundária subordinada. A mineralização de titânio está associada à concentração residual de anatásio no horizonte aloterítico de base, gerado a partir dos grandes volumes de perovskita encontrados nos bebedouritos. Em geral, os ETR estão concentrados no horizonte aloterítico de base, contidos principalmente em monazita. Em solos derivados de bebedouritos, como os estudados no presente trabalho, monazita geralmente ocorre associada com anatásio. Nesses casos, ela é gerada a partir da liberação de ETR da perovskita, durante a conversão desta em anatásio, seja por processos hidrotermais ou pedogenéticos, complexados com o fosfato disponível a partir da lixiviação de apatita, que se torna instável no horizonte aloterítico. Outro modo de ocorrência de monazita é como produto metassomático formando pseudomorfos sobre cristais de carbonato. A concentração residual de monazita desta variedade é a responsável pelos maiores teores de ETR encontrados no horizonte intempérico. 


\section{Abstract}

The Salitre complex in the Alto Paranaíba Igneous Province (APIP) is an ultrapotassic carbonatite- and phoscorite-bearing alkaline multi-intrusion complex, divided into three main outcropping bodies (Salitre I, II, and III). The weathering profile developed over the complex remobilized and concentrated fosfate, rare earth elements (REE) and titanium to economic levels. Exploratory drill cores over the bebedouritic portion of the deposit allows the detailing of the weathering profile, its mineralogy and secondary mineralization.

Salitre I weathering profile, as in other APIP deposits, is divided in fresh rock, altered rock, isalterite and alloterite, based on macroscopic and field observations. In this work, fresh rock designation is used to fresh rock not affect by weathering processes, even considering the presence of metassomatic alteration. Mineralogical and textural analysis in the optical and electronic microscope associated with mineral chemistry, whole rock and alterite geochemistry confirms that this division is reflected in the weathering profile texture and mineralogy.

Fresh Rock Horizon contains olivine-bebedourites and perovskite-bebedourites with different degrees of calcium and magnesiocarbonatite metassomatism. Metassomatic alteration generates newly formed carbonate and magnetite; modify the primary silicate minerals (olivine, diopside and phlogopite) and converts perovskite to anatase. F-apatite rich phoscorite cumulates are also described in fresh rock samples.

Altered Rock Horizon is characterized by precipitation of iron oxide/hydroxides in the contact surface of carbonate grains. Phlogopite and tetraferriphlogopite crystals shows signs of $\mathrm{K}$ loss.

Carbonate is completely weathered in the isalteritic horizon, and weathering-resistant minerals are concentrated. Secondary apatite precipitates as crystalline aggregates in the fractures of the igneous apatite. This horizon is divided in Lower Micaceous Isalterite (overall phlogopite morphology is maintained, even when weathered to vermiculite), Upper Micaceous Isalterite (rich in vermiculite and subordinated iron oxides/hydroxides) and Oxidized Isalterite (rich in iron oxides/hydroxides and subordinated clay minerals). Perovskite alteration to secondary anatase intensifies upwards and it is frequently associated with secondary monazite. 
Apatite is no longer stable at Alloterite level, being replaced by crandallite group secondary phosphates. Perovskite is completely weathered to anatase at this level. The alloterite horizon is divided in Lower Alloterite (large anatase and monazite volumes immersed in iron oxydes/hydroxides) and Upper Alloterite (rich in kaolinite and gibbsite).

Whole rock and alterite chemical analyses reflect the mineralogy, with weathered horizons chemical signature similar to the fresh rock. Phosphate mineralization results mainly from residual accumulation of igneous apatite from bebedourites and phoscorites; secondary apatite generated from weathering processes is subordinated. Titanium mineralization results from residual accumulation of anatase in Lower Alloterite, weathered from large perovskite volumes found in bebedourites. REE values increase up to the Lower Alloterite Horizon, contained mainly in monazite. Monazite and anatase are closely associated in alterites derived from bebedourites. Monazite is generated from REE release of perovskite structure during the conversion to anatase, both from hydrothermal or pedogenetic processes, complexed with the phosphate available from apatite weathering. Metassomatic pseudomorphic monazite over carbonate crystals was detected and is responsible for the highest REE grades found in the weathering profile. 
Sumário

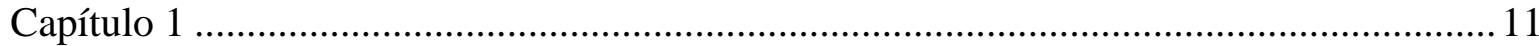

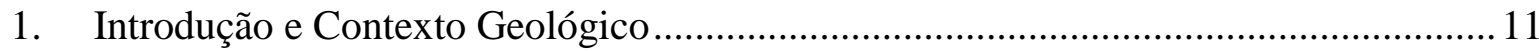

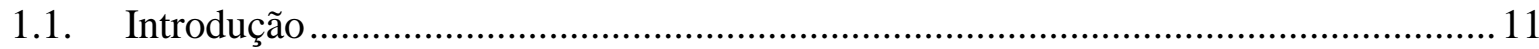

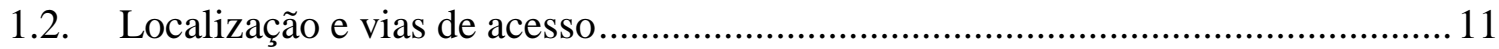

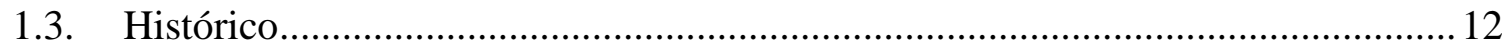

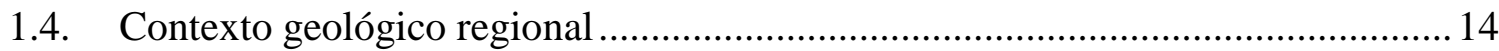

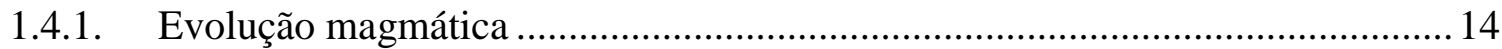

1.4.2. Evolução do perfil de intemperismo ……………….................................... 18

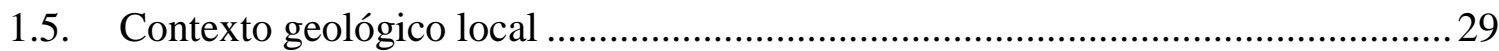

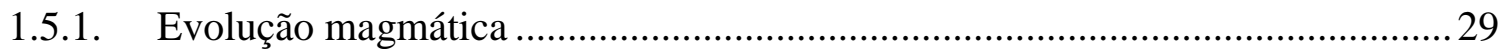

1.6. Mineralogia de complexos carbonatíticos e mineralização associada......................30

1.7. Aspectos texturais e evolutivos do manto de intemperismo em rochas máficas

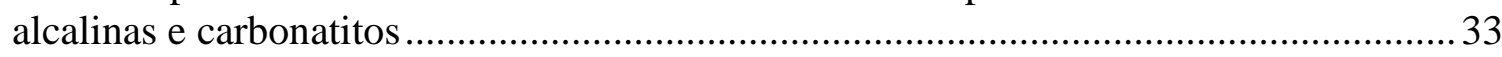

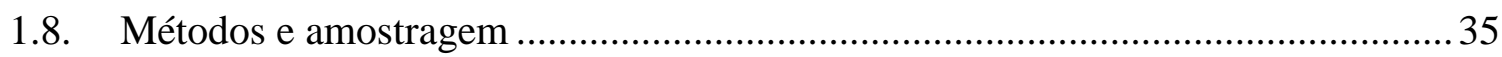

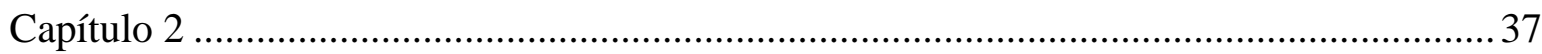

2. The weathering profile and the P, Ti and REE mineralization of the Salitre alkaline-

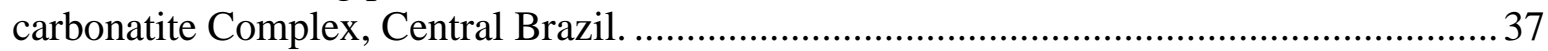

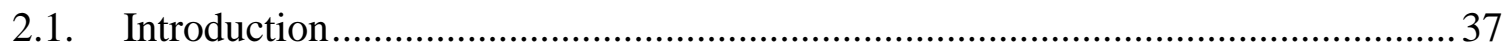

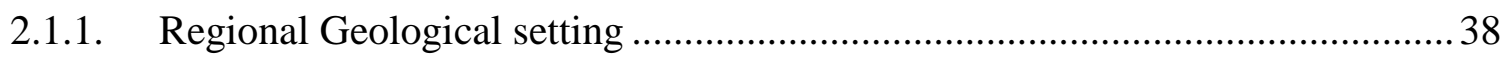

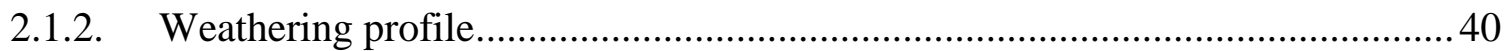

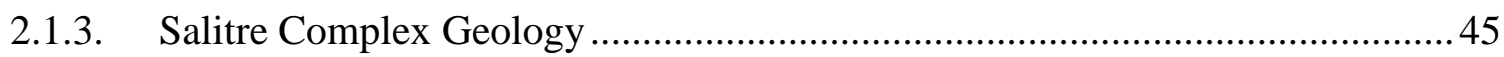

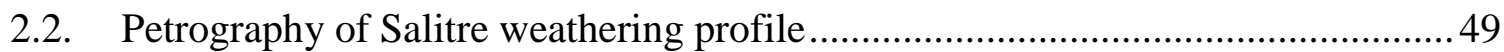

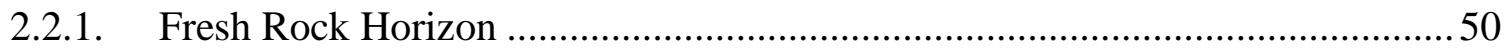

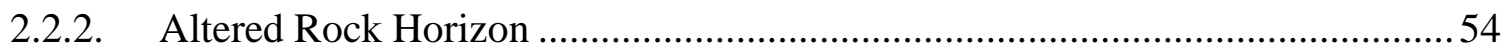

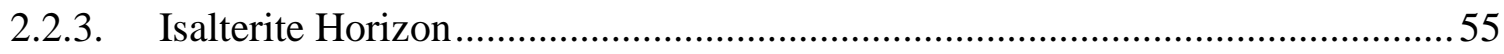

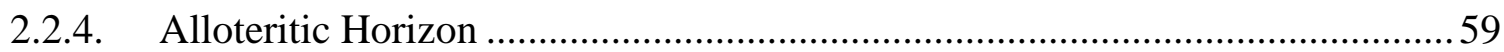

2.3. P, REE and Ti bearing mineralogy and mineral chemistry ………………...........62

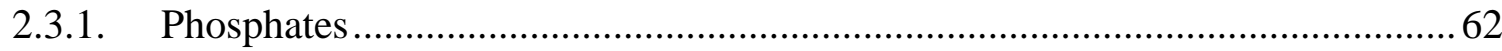

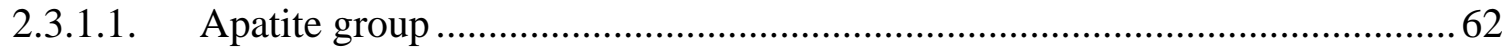

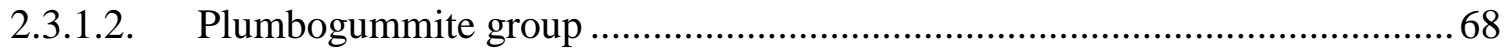

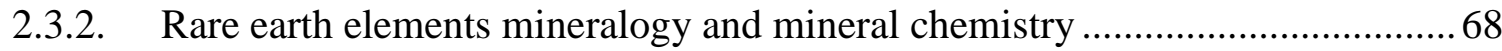

2.3.2.1. Monazite group..................................................................................... 71

2.3.2.2. Other REE-bearing minerals ................................................................. 74 
2.3.3. Titanium mineralogy and mineral chemistry ........................................... 74

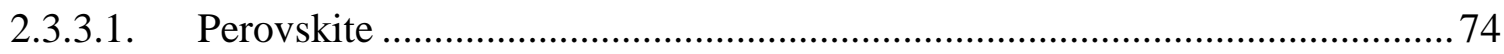

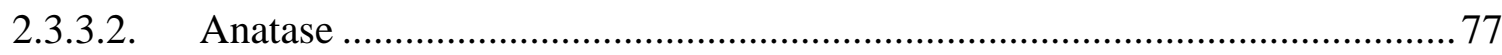

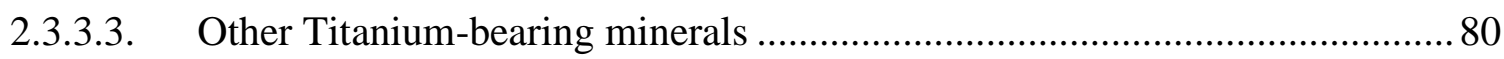

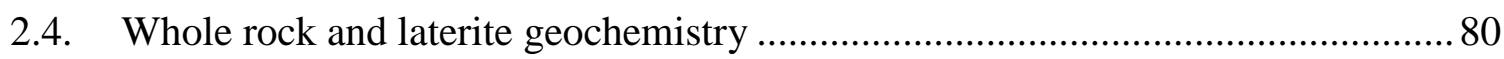

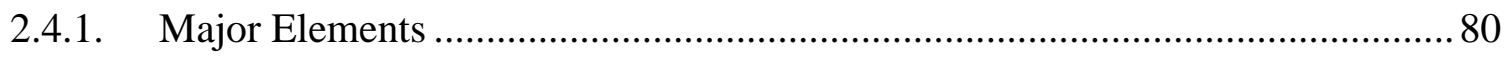

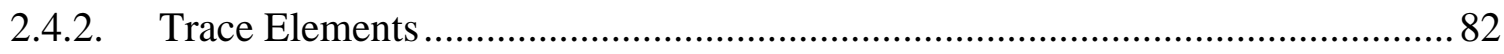

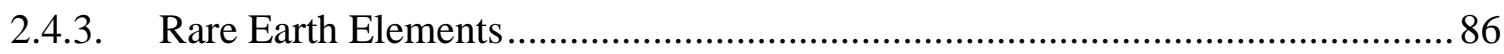

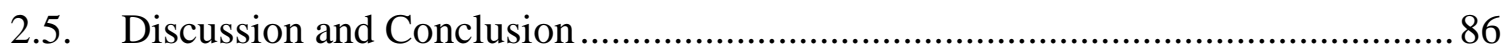

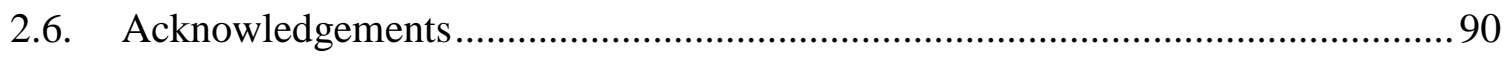

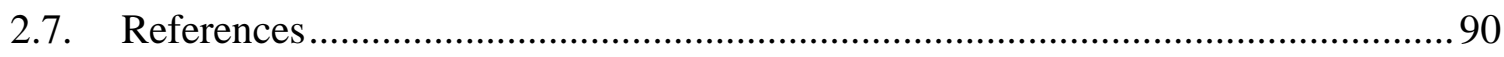

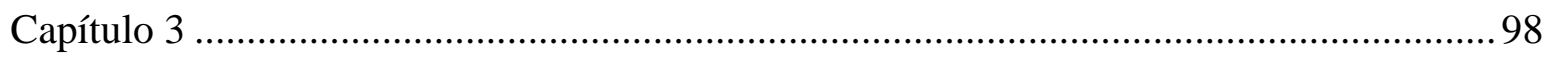

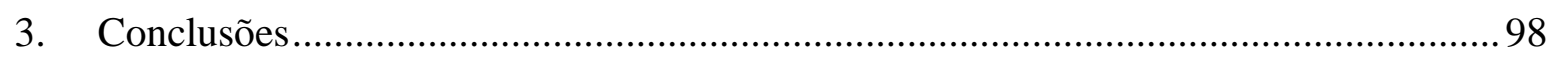

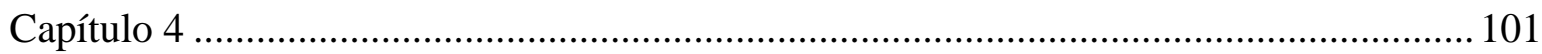

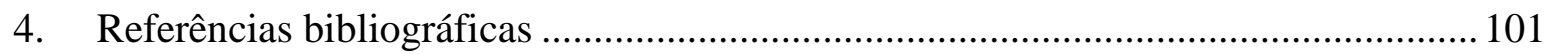

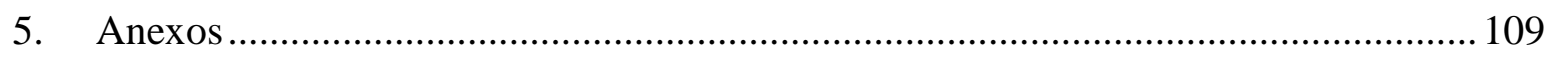


Índice de Figuras

Figura 1.1: Mapa de localização e acesso à área de estudo.

Figura 1.2: Localização das províncias alcalinas nas margens da Bacia do Paraná. Círculos vazados representam rochas do Eocretácio; círculos preenchidos representam rochas do Neocretácio a Eoceno. Adaptado de Gibson et al, 1995a e 1995b. 15

Figura 1.3: Perfil laterítico esquemático do Complexo de Catalão I (Oliveira e Imbernon, 1998).

Figura 1.4: Padrões de ETR em Catalão, normalizados para Condrito: A) rocha fresca, foscorito (1A) e carbontito (1C); B) rocha alterada (2) e saprolito isalterítico (3, 4 e 5); C) saprolito aloterítico (6 e 7) e solo (8). D) saprolito silicificado (10, 11 e 12), rico em ETR. Retirado de Oliveira e Imbernon (1998).

Figura 1.5: Padrões normalizados para Condrito de ETR em Araxá: A) solo; B) saprolito aloterítico/laterita C) saprolito isalterítico/saprolito e D) rochas alcalinas. Retirado de Morteani e Preinfalk (1996).

Figura 1.6: Análises de ETR para minerais de Juquiá: A) padrões normalizados a Condrito dos minerais primários: apatita 1 e 2, carbonato e dolomita, flogopita e barita; B) padrões normalizados a dolomita dos minerais secundários, hidróxidos de Fe e Mn e calcita; C) padrões normalizados a flogopita dos minerais secundários gorceixita pseudomórfica, gorceixita amorfa e wavelita. Retirado de Walter et al, 1995............. 27

Figura 1.7: Mapa geológico do substrato dos corpos de Salitre I, II e III, com base em furos de sonda e geofísica. As unidades representadas na figura correspondem a zonas de predominância de um determinado tipo litológico e não a zonas homogêneas. Barbosa et al. (2012). 30

Figure 2.1: Schematic mineralogy of the weathering profile derived from bebedouritic, phoscoritic and carbonatitic series in Brazilian carbonatites. Straight arrows represent minerals that remain unchanged during metasomatism/weathering, dotted arrows represent respective mineral alteration. Red indicates metasomatism and black indicates weathering. (*) indicates minerals formed due to precipitation/nucleation of weathering solutions. Data from Morteani and Preinfalk (1996), Delvigne (1998), Oliveira and Imbernon (1998), Wilson (1999), Brod (2001), Toledo and Pereira (2003), Wilson (2004), Freyssinet (2005), Ribeiro (2008), Azzone and

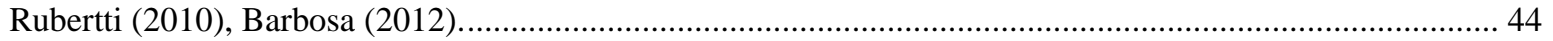

Figure 2.2: Distribution of the different levels and horizons in a typical lateritic profile (Delvigne, 1996) and average modal composition of main mineral groups for main rock systems of the APIP deposits.................. 45

Figure 2.3: Geological map of the Alto Paraíba Igneous Province. From Barbosa (2009) after Oliveira et al (2004) .. 46

Figure 2.4: Interpretative geological sketch of the Salitre complex (Barbosa, 2009) and the location of the drill cores examined and sampled during this work. 47

Figure 2.5: Photomicrographs of petrographic features of the fresh rock horizon. (a) Typical metasomatized bebedourite association of perovskite with magnetite rims, metasomatic carbonate and fine grained tetraferriphlogopite. (b) Large Al-rich phlogopite crystals showing dark red rims of tetraferriphlogopite alteration. (c) plane-polarized and (d) cross-polarized light image of apatite crystal with edges of high-Sr and high-REE apatite with high birrefringence. (e) cross-polarized image of carbonatite vein with round apatite and interstitial sulphide accumulation. (f) Dissolved magnetite with residual ilmenite trellis. $\mathrm{pv}=$ perovskite; $\mathrm{phl}=$ phlogopite; ap = apatite; met $=$ metasomatic $; \mathrm{cc}=$ calcite $;$ ilm = ilmenite . 52

Figure 2.6: Back-scattered electron images showing selected petrographic features of the fresh rock horizon (a) apatite accumulation on phoscorite, with interstitial anhedral apatite rich in REE and Sr. (b) detail of (a). (c) intercumulus monazite lamellae in carbonatite vein. (d) Unaltered perovskite in metasomatized bebedourite intruded by D3 carbonatite. (e) Metasomatic anatase in bebedourite intruded by D4 carbonatite, showing complex texture. (f) Detail of (e): residual perovskite core, showing corrosion gulfs and metasomatic anatase, monazite and dolomite. $\mathrm{pv}=$ perovskite $; \mathrm{phl}=$ phlogopite $; \mathrm{ap}=$ apatite $;$ met $=$ metasomatic $; \mathrm{cc}=\mathrm{calcite} ;$ dol $=$ dolomite anat $=$ anatase $;$ mon $=$ monazite $;$ mag $=$ magnetite . 
Figure 2.7 Photomicrographs of petrographic features of the altered rock horizon. (a) Iron oxide/hydroxide concretions interstitial to calcite crystals. (b) Light colored, K-depleted layers in phlogopite, with minor iron oxide/hydroxides along the cleavages. $\mathrm{Phl}=$ phlogopite....... 54

Figure 2.8: Photomicrographs (a/b/c/f) and back-scattered electron images (d/e) of petrographic features of the isalteritic horizon. (a) morphologically unchanged, K-depleted phlogopite altered to vermiculite; and (b) diopside weathering to iron oxide/hydroxide impregnated clays from lower micaceous isalterite (c/d) supergenic apatite (high birefringence) filling fractures in igneous apatite, from lower micaceous isalterite. (e) rare radial agglomerate of acicular secondary apatite, from lower micaceous isalterite. (f) deformed sheet-like clays with mild iron oxide/hydroxide impregnation from upper micaceous isalterite. ap = apatite; phl = phlogopite; pv = perovskite; diop = diopside; $\mathrm{Fe}$ ox/hydrox = iron oxide/hydroxides; mag = magnetite. 57

Figure 2.9: Photomicrographs $(\mathrm{a} / \mathrm{b})$ and back-scattered electron images (c/d/e) of weathered perovskites from the upper micaceous isalterite. (a) Subhedral perovskite with corrosion tunnels impregnated with anatase. (b) acicular monazite crystals inside anatase "tunnel" developed inside perovskite. (c/d/e) weathered perovskite with corrosion gulfs and tunnels. Residual anatase contains traces of monazite (white). Detail of alteration channel with anatase accretionary walls and acicular monazite aggregate. $\mathrm{pv}=$ perovskite; anat $=$ anatase; mon $=$ monazite. 58

Figure 2.10: Photomicrographs $(\mathrm{a} / \mathrm{c})$ and Back-scattered electron images $(\mathrm{b} / \mathrm{d} / \mathrm{e} / \mathrm{f})$ of pseudomorphic monazites. $(\mathrm{a} / \mathrm{b})$ residual accumulation of pseudomorphic monazite in Oxidized Isalterite horizon, immersed in a porous and heterogenic matrix of iron (+-Si) oxide/hydroxide. (c/d/e) individual and geminated pseudomorphic monazite crystals from lower alloterite showing large cavities and complex textures. (f) calcite crystal partially replaced by monazite in fresh metasomatized bebedourite. Higher gray levels indicate higher REE and Th grades. anat $=$ anatase $;$ mon $=$ monazite $;$ phl $=$ phlogopite $; c c=$ calcite. 60

Figure 2.11: Photomicrographs (a/b/d) and Back-scattered electron images (c/e/f) of petrographic features of the lower alloterite. $(\mathrm{a} / \mathrm{b} / \mathrm{c})$ perovskite completely weathered to anatase in a iron oxide/hydroxide matrix, a very common feature of the lower alloterite; (b) is a detail of accretionary texture of anatase.(d) Quartz banded accumulation at the base of the lower alloterite. (e) Massive microcrystalline crandallite aggregate. (f) Layered crandallite associated with Mn oxide/hydroxide agglomerate. Fe ox/hydrox = iron oxide/hydroxides; anat = anatase crand $=$ crandallite $;$ qtz $=$ quartz.

Figure 2.12: Substitutions and compositional trends for apatite in Salitre weathering profile. Crosses represent EDS analysis, and circle/diamond represent WDS analysis. a.p.f.u. = atoms per formula unit.

Figure 2.13: Substitutions and compositional trends for crandallite (a/b/c) and monazite (d/e/f) in Salitre weathering profile. Legend for figures $a / b$ in figure $a$. Legend for figures $d / e / f$ in figure $d$. Cross-cut symbols represent EDS analysis, and circles represent WDS analysis. 70

Figure 2.14: Substitutions and compositional trends for anatase in Salitre weathering profile. Cross-cut symbols represent EDS analysis, and circle/diamonds represent WDS analysis. Legend in figure a. a.p.f.u.= atoms per formula unit.

Figure 2.15: Chondrite-normalized (Thompson et al., 1984) trace-element diagrams for selected Salitre Complex weathering profile samples. Grey areas represent the average of the fresh bebedourite samples. (a) bebedourites metasomatized by C3 calciocarbonatites (b) phoscorites (c) bebedourites metasomatized by D4 magnesiocarbonatite (d) isalterite. (e) lower alloterite. (f) upper alloterite. Met = metasomatized; Bbd = bebedourite; Phc $=$ phoscorite.

Figure 2.16: Chondrite-normalized (Boynton, 1984) REE patterns for selected Salitre Complex weathering profile samples. Grey areas represent the average of the bebedourite samples. (a) igneous paragenesis. (b) isalterite. (c) lower alloterite. (d) upper alloterite. Met = metasomatized; $\mathrm{Bbd}=$ bebedourite; Phc $=$ phoscorite.

Figure 2.17: Schematic mineral abundance and distribution on studied samples of Salitre weathering profile. 
Índice de Tabelas

Table 2-1: Classification of the intemperic profile proposed in this work compared with the classification of Grasso (2015), Oliveira \& Imbernon (1998) and Ribeiro (2008) 42

Table 2-2. Representative apatite analysis from B1a Salitre bebedourites........................................................ 65

Table 2-3. Representative crandallite analysis from B1a Salitre bebedourites................................................ 69

Table 2-4: Representative monazite analysis from B1a Salitre bebedourites................................................. 73

Table 2-5: Representative Perovskite analysis from B1a Salitre bebedourites.................................................. 76

Table 2-6. Representative anatase analysis from Salitre alterites.................................................................. 78

Table 2-7. Representative whole-rock chemical analyses from selected samples of the weathering profile over

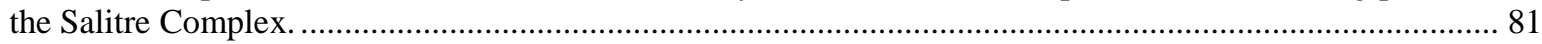




\section{Capítulo 1}

\section{Introdução e Contexto Geológico}

\subsection{Introdução}

A Província Ígnea do Alto Paranaíba (APIP) destaca-se entre as áreas de ocorrência de complexos alcalino-carbonatíticos no Brasil por sua complexidade petrológica decorrente da associação entre carbonatitos e rochas alcalinas ultrapotássicas e também pelo grande número e variedade de depósitos minerais desenvolvidos nesses complexos. Em geral, a mineralização resultante dos processos magmáticos pode ser intensificada por processos intempéricos, gerando depósitos economicamente viáveis. Nesse contexto encontra-se o depósito polimetálico do Salitre, escolhido como tema para o presente estudo. O grau de intemperismo a que os complexos carbonatíticos da APIP foram submetidos originou enriquecimento supergênico de pirocloro e apatita (Imbernon et al., 1994, Gierth \& Baecker, 1986; Fava, 2001) tradicionalmente explorados para fins comerciais desde o século 19. O perfil intempérico concentra também titânio, elementos terras raras, vermiculita e barita, ainda não aproveitados economicamente.

O trabalho teve como objetivo a caracterização mineralógica com ênfase nos minerais de minério do perfil de intemperismo do depósito do Salitre. Propôs-se também, descrever a relação da mineralização primária em rocha fresca com a mineralização supergênica. A dissertação está estruturada em três partes: no capítulo 1 são abordados o histórico do conhecimento sobre a região, o contexto geológico no qual se situa o complexo de Salitre e uma revisão sobre a ocorrência da mineralização secundária associada a complexos carbonatíticos da APIP. O capítulo 2 consiste de um artigo para submissão ao periódico Economic Geology, caracterizando o perfil laterítico amostrado do depósito, sua petrologia, sua mineralogia e a relação entre a rocha fresca e o material intemperizado. O capítulo 3 sumariza as conclusões do trabalho.

\subsection{Localização e vias de acesso}


O Complexo Alcalino-Carbonatítico de Salitre ocorre imediatamente a sul do complexo de Serra Negra, na região de Patrocínio, MG. Situa-se a cerca de 600 km de Brasília, via BR-040 até Cristalina, e daí via BR-050 até Uberlândia, e então pela BR-365 até o município de Patrocíno (Figura 1.1).

\subsection{Histórico}

A Província Ígnea do Alto Paranaíba (APIP), oeste de Minas Gerais e sul de Goiás, resulta de intenso magmatismo alcalino que gerou corpos intrusivos (diques, condutos, diatremas e complexos carbonatíticos) e extrusivos (lavas e piroclásticas) de afinidade kamafugítica (Leonardos et. al., 1991, Almeida e Svisero, 1991, Gibson et al., 1995a, Carlson et al., 1996, 2007, Brod et al., 2000, 2004, Comin-Chiaramonti e Gomes, 2005). É uma das maiores províncias ultramaficas-ultrapotássicas mundiais (Gibson et al., 1995a), e uma das poucas associações kamafugíticas-carbonatíticas conhecidas (Brod et al., 2000).

É uma importante província mineral do Brasil, onde ocorrem ambientes geológicos favoráveis a mineralizações de diamante em kimberlitos e aluviões, e de nióbio, fosfato, titânio, vermiculita, terras raras e barita, entre outros, associados a corpos máficoultramáficos alcalinos Cretáceos portadores de carbonatito, intrudidos em terrenos PréCambrianos. Exemplos destes últimos são os Complexos de Araxá, Tapira, Salitre, Serra Negra e Catalão I e II.

O complexo de Salitre consiste em 3 intrusões distintas, de dimensões variadas. Salitre I, de forma aproximadamente oval, com cerca de $7 \mathrm{~km}$ na direção N-S e $5 \mathrm{~km}$ na direção E-W, é o maior corpo dos três. É composto basicamente por bebedourito, tinguaito, traquito, fenito, apatita-carbonatito, calcita carbonatito e foscorito. O corpo de Salitre II, um plug de 2,5 $\mathrm{km}^{2}$ situado entre Serra Negra e Salitre I, contém principalmente rochas ultramáficas (dunito, perovskitito, bebedourito, localmente cortados por diques e veios carbonatíticos). Salitre III é um pequeno corpo a sul de Salitre I, essencialmente formado por piroxenitos, com foscoritos subordinados (Brod et al 2004). 


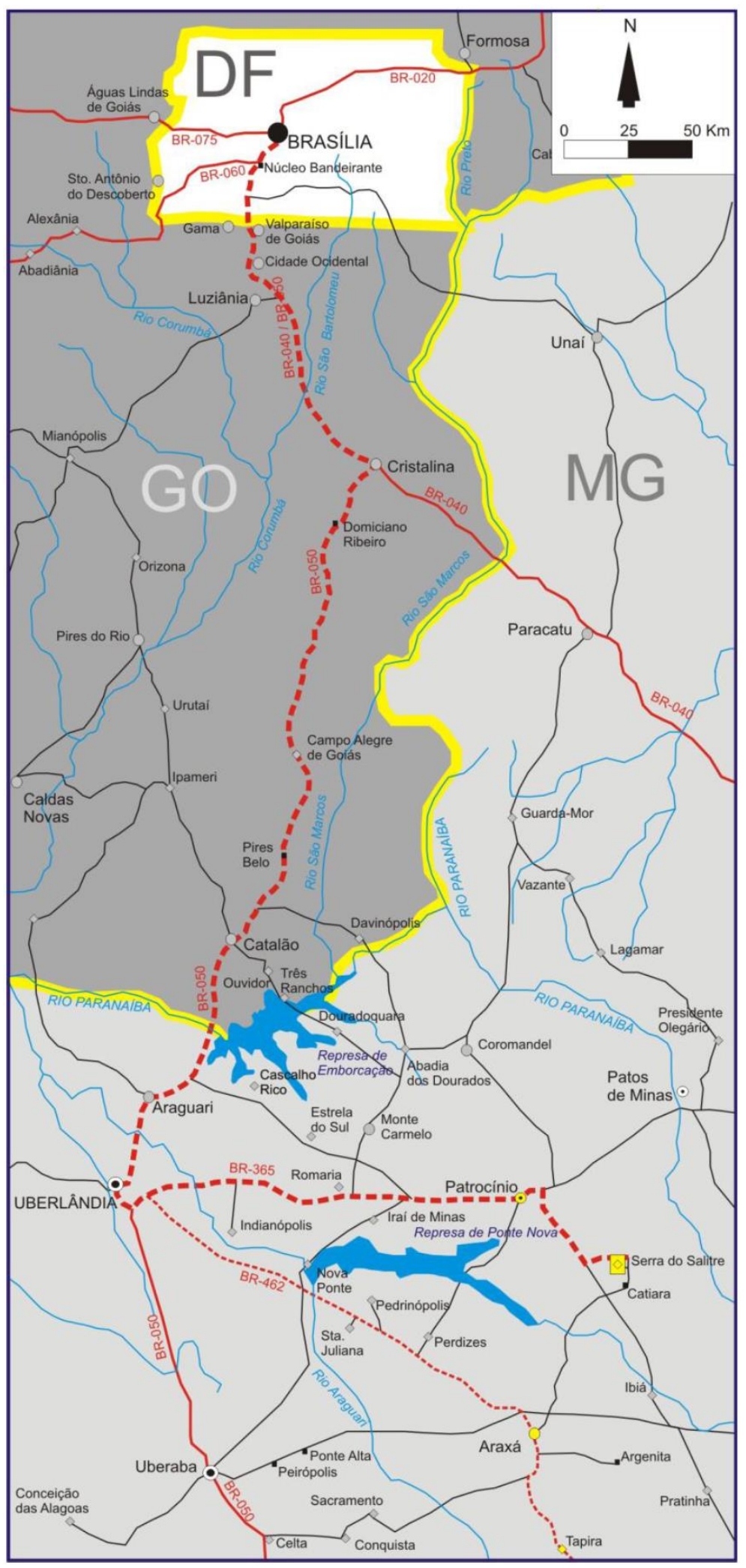

Figura 1.1: Mapa de localização e acesso à área de estudo. 
O projeto Salitre é considerado um ativo de fosfato de classe mundial e tem capacidade estimada de produção de 2 milhões de toneladas/ano de rocha fosfática. Durante o ano de 2011 o departamento de exploração mineral da Vale - DIPM desenvolveu uma extensa campanha de sondagem com o objetivo de estabelecer a dimensão da mineralização em titânio e terras-raras, com foco principalmente no perfil de intemperismo do projeto.

\subsection{Contexto geológico regional}

\subsubsection{Evolução magmática}

A intensa atividade magmática que ocorreu do Eocretáceo ao Eoceno na porção central e sul do Brasil é correlacionada com a instalação de diversas províncias alcalinas nas margens da Bacia do Paraná, intensamente estudadas durante as últimas décadas (Morbidelli et al, 1995a,b; 1997; Bizzi et al, 1995; Gibson et al, 1995a, b, 1997; Comin-Chiaramonti \& Gomes, 1996; Comin-Chiaramonti et al, 1997; Carlson et al, 1996; Thompson et al, 1998, Brod et al., 2000, 2001, Junqueira-Brod et al., 1998, 2000, 2002, 2005). Geograficamente e geocronologicamente as províncias podem ser agrupadas em três categorias: ao Norte (Poxoréu, Goiás, Alto Paranaíba) de idade Neocretácia; ao Sul (Paraguai Oriental na margem oeste e Ponta Grossa na margem leste) apresentam idades variáveis, com predominância de rochas do Eocretáceo e ocorrências localizadas de rochas Neocretácias; na porção oriental (Serra do Mar) com rochas mais jovens, com idades entre o Neocretácio e o Eoceno.

Plumas mantélicas são apontadas como responsáveis pela formação dos basaltos da Bacia do Paraná e das províncias alcalinas associadas a suas margens (Figura 1.2) (Herz, 1977; Toyoda et al., 1994; Gibson et al., 1995 a,b, 1997; Bizzi et al., 1995, VanDecar et al., 1995; Thompson et al., 1998).

Neste contexto, o magmatismo do Eocretáceo, incluindo os basaltos do sistema Paraná-Etendeka e as rochas alcalinas contemporâneas, é atribuído ao impacto da pluma de Tristão da Cunha (Milner et al., 1995; Gibson et al., 1997; Milner \& Le Roex, 1996; Le Roex \& Lanyon, 1998), enquanto o magmatismo Neocretáceo a Eoceno, nas margens norte e nordeste da Bacia do Paraná, é tido como resultado da pluma de Trindade (Crough et al., 1980; Gibson et al., 1995b, 1997; Thompson et al., 1998). As províncias de Poxoréu, de Goiás e do Alto Paranaíba estariam relacionadas ao impacto inicial desta pluma sob a 
litosfera do Brasil Central, enquanto a Província Serra do Mar, mais jovem, representaria o "vazamento" de manto anomalamente quente para o sul, à medida que a litosfera espessa do Cráton do São Francisco passava sobre o local da pluma, durante a migração do Continente Sul-Americano para oeste (Thompson et al., 1998).

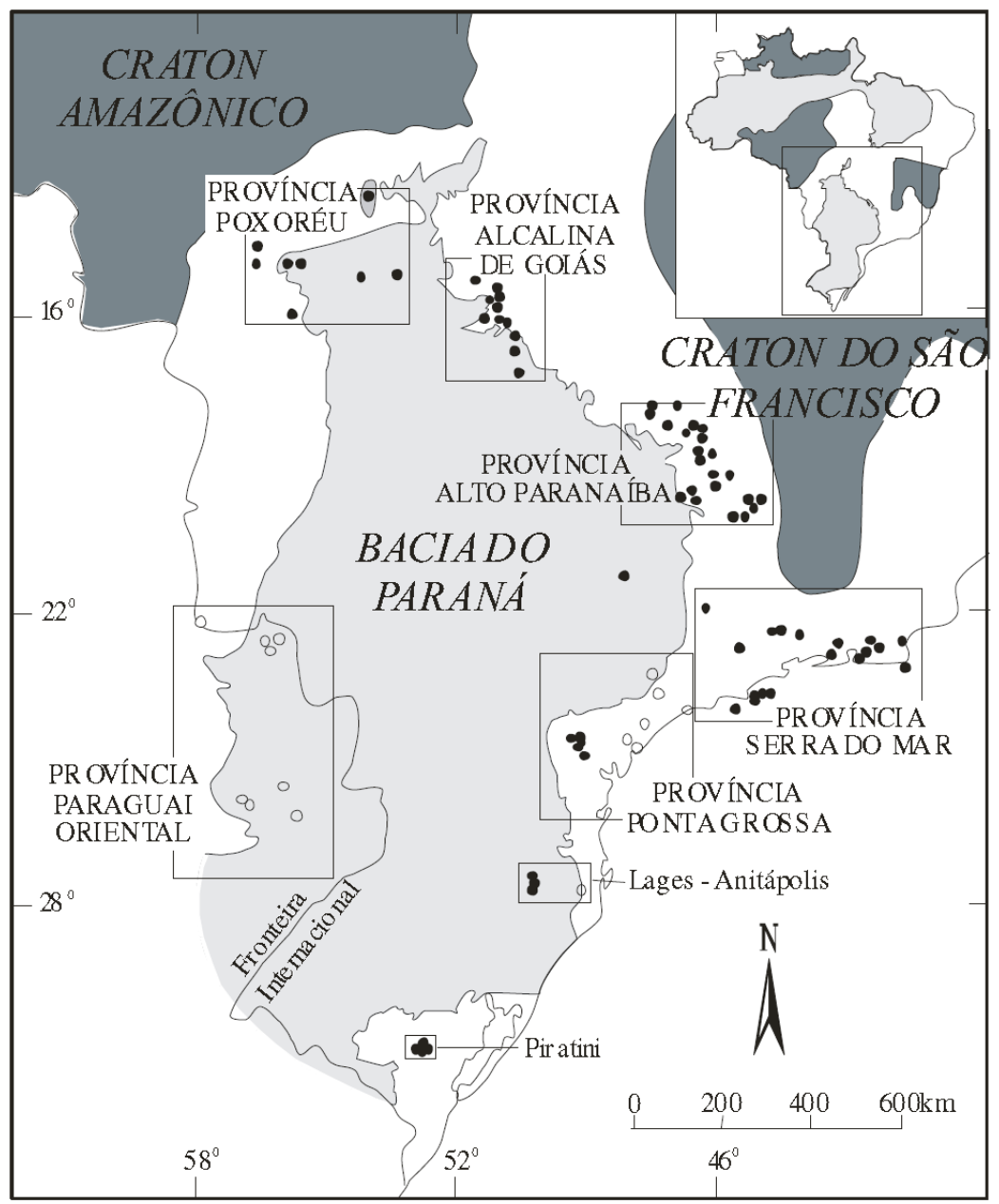

Figura 1.2: Localização das províncias alcalinas nas margens da Bacia do Paraná. Círculos vazados representam rochas do Eocretácio; círculos preenchidos representam rochas do Neocretácio a Eoceno. Adaptado de Gibson et al, 1995a e 1995b.

O Arco do Alto Paranaíba, na porção oeste de Minas Gerais e que divide as bacias do Paraná e Sanfranciscana, tem sido prospectado desde o século XVIII. É uma estrutura alongada segundo NW-SE, cujo soerguimento iniciou-se no Neocretácio, marcada por anomalias magnéticas interpretadas como resultado de enxames de diques máficos ao longo da direção N50W (Bosum, 1973). As anomalias são coincidentes com corpos alcalinos intrusivos, podendo representar intrusões ainda não expostas. 
No Arco do Alto Paranaíba estabeleceu-se a Província Ígnea do Alto Paranaíba (Almeida, 1983; Gibson et al., 1995b) durante o Neocretácio. A província é interpretada como resultado de intenso magmatismo máfico-ultramáfico-alcalino e ultrapotásssico, gerando corpos intrusivos (diques, condutos, diatremas e complexos plutônicos) e extrusivos (lavas e piroclásticas). De acordo com Gibson et al., (1995a,b), a província formou-se em um período restrito, entre 80 e 90Ma, apesar de um intervalo de idades mais amplo ser mencionado na literatura (Ulbrich \& Gomes, 1981; Sonoki \& Garda, 1988; Bizzi et al., 1995). Dados mais recentes de Sgarbi et al., (2004) para datação U/Pb em perovskita dos kamafugitos do grupo Mata da Corda são consistentes com um intervalo mais restrito de idades para a província.

As rochas alcalinas da província incluem kimberlitos, olivina lamproitos madupíticos e kamafugitos, além de complexos alcalino-carbonatíticos e diques de flogopita picrito. Kamafugitos são as rochas mais abundantes na província. De forma mais restrita ocorrem olivina lamproitos madupíticos (Gibson et al., 1995a) e pipes de kimberlito diamantífero (Gonzaga e Tompkins, 1991). O grupo Mata da Corda pertencente a estratigrafia da Bacia Sanfranciscana, é formado por kamafugitos vulcânicos associados ao magmatismo alcalino da Província (Gibson et al 1995a, Sgarbi \& Gaspar, 1995). A presença de um grande número de xenólitos ultramáficos nos derrames de kamafugitos pode indicar a presença de complexos carbonatíticos em profundidade (Seer \& Moraes, 1988).

Os complexos carbonatíticos da APIP são intrusões ultramáficas-carbonatíticas de dimensões relativamente grandes (até $65 \mathrm{Km}^{2}$ ). Fazem parte da província os complexos de Catalão I e II no sul de Goiás, e Serra Negra, Salitre I, II e III, Araxá e Tapira, no oeste de Minas Gerais. Os complexos intrudem rochas metamórficas neoproterozóicas dos domínios interno e externo da Faixa Brasília (Gibson et al., 1995a, Brod et al., 2004). A intrusão do complexo alcalino deforma as encaixantes mais resistentes em estruturas dômicas que geram padrões de drenagem centrípeta característicos (Mariano \& Marchetto, 1991, Danni et al., 1991). A maioria dos complexos é coberta por uma espessa camada de solo, que favorece a concentração econômica de fosfato e nióbio atualmente extraídos, entre outros minerais ainda não explorados economicamente. 
Complexos carbonatíticos podem ser associados ao magmatismo alcalino sódico (Le Bas, 1985), caracterizados por rochas silicáticas da série ijolítica (Jacupiranguito-MelteigitoIjolito-urtito) ou a magmatismo ultrapotássico, que tende a produzir sequências bimodais de rochas silicáticas (dunitos/clinopiroxenitos/bebedouritos e sienitos). Rochas vulcânicas associadas, se preservadas, são, respectivamente, das séries nefelinítica e kamafugítica. A associação de carbonatitos com kamafugitos é mais rara, mas reconhecida em outras partes do mundo, como na Itália (Stoppa \& Cundari, 1995), na China (Yang and Woolley, 2006), e no Brasil, como a Província Alcalina de Goiás (Junqueira-Brod, 1998; 2002, Brod et al., 2005). Processos de cristalização fracionada e/ou imiscibilidade de líquidos, mistura de magmas, contaminação crustal e degasseificação associados a múltiplos estágios de intrusão são responsáveis pela evolução dos complexos.

Os complexos carbonatíticos da APIP são associados ao magmatismo ultrapotássico (Lloyd e Bailey, 1991, Gibson et al., 1995b, Brod, 1999, Brod et al., 2000), não ocorrendo a série Ijolítica (nefelina é um mineral praticamente ausente a não ser nos termos sieníticos mais diferenciados, Brod et al., 2004). Do ponto de vista petrogenético, podem ser considerados como compostos por proporções variáveis de rochas pertencentes a três séries de diferenciação distintas (bebedourítica, foscorítica e carbonatítica), evoluídos a partir de magmas primitivos de afinidade kamafugítica (flogopita picritos). Metassomatismo alcalino de intensidade variável transformou as rochas ultramáficas primárias em flogopititos e fenitizou em grau variável as encaixantes neoproterozóicas.

A série Bebedourítica é gerada por cristalização fracionada a partir de um magma silicático ultrapotássico (flogopita picrito, Brod, 1999, Brod et al., 2000). É composta por variações modais de olivina, clinopiroxênio, apatita, perovskita, magnetita e flogopita, eventualmente apresentando feições de acamamento magmático (preservadas especialmente em Tapira e Salitre). Sienitos são observados como termos finais na série de diferenciação. A série Foscorítica apresenta rochas derivadas de magmas fosfáticos. O foscorito propriamente dito é constituído por proporções equilibradas de apatita, magnetita e olivina (Yegorov, 1993). Dunitos, magnetititos, apatititos e nelsonitos (apatita +magnetita) são comuns. A série Carbonatítica contém rochas com mais de $50 \%$ de carbonatos, 
essencialmente dolomita, calcita, calcita+dolomita, ou dolomita+Fe-dolomita/ankerita, com grande variedade de acessórios.

Os complexos carbonatíticos da APIP também registram um metassomatismo alcalino de intensidade variável, que transformou as rochas ultramáficas primárias em flogopititos e fenitizou em grau variável as encaixantes neoproterozóicas.

\subsubsection{Evolução do perfil de intemperismo}

Os mantos de alteração laterítica derivados de carbonatitos são mais abundantes em regiões tropicais, como no Brasil (Berbert, 1984; Hirano et al., 1987; Kamitani e Hirano, 1987; Alcover Neto e Toledo, 1993; Angélica e Costa, 1993), mas também ocorrem em outros lugares no mundo (Austrália, China e África). A espessura do manto de alteração pode atingir mais de 100m (Toledo et al., 2004b) e apresenta uma zonação mineralógica vertical bem desenvolvida (Oliveira e Imbernon, 1998).

Estudos convencionais de cálculo do balanço de massa para quantificação da transferência de elementos em perfis lateríticos são particularmente difíceis devido à ausência de elementos imóveis (isoelementos) preservados em todo o perfil (Walter et al., 1995). Walter et al., 1995, afirmam que nem mesmo o titânio pode ser utilizado, pois pode haver transferência de $\mathrm{TiO}_{2}$ resultado da lixiviação da magnetita. Porém, observações petrográficas detalhadas podem indicar tendências de laterização em escala local a partir das observações texturais e químicas das relações entre os minerais secundários e os minerais primários. Alguns autores observam que no perfil de intemperismo os terras raras leves (LREE) são geralmente mais móveis que os terras raras pesados (HREE) (Duddy, 1980; Topp et al., 1985)

e podem se acumular em alguns níveis do material intemperizado, aumentando a razão $\mathrm{La} / \mathrm{Yb}$.

Em seguida, sumarizamos as principais características do perfil de intemperismo de alguns dos depósitos mais estudados da APIP (Catalão, Araxá e Tapira) e do depósito de Juquiá. 


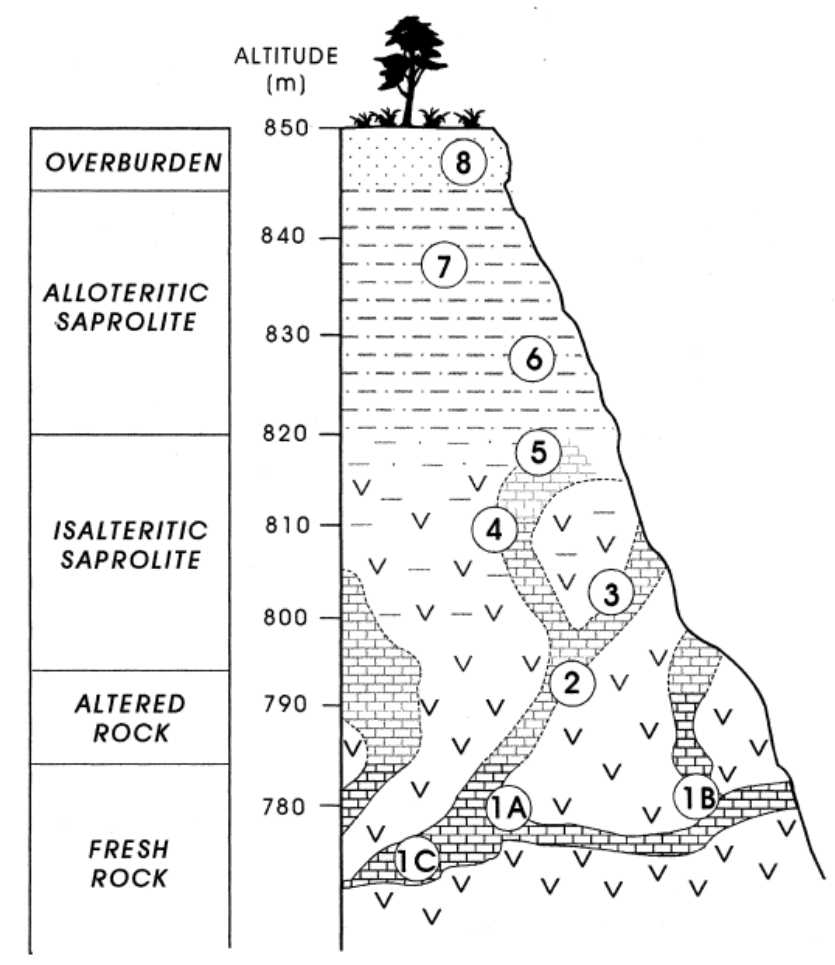

Figura 1.3: Perfil laterítico esquemático do Complexo de Catalão I (Oliveira e Imbernon, 1998).

\section{Catalão}

As ocorrências carbonatíticas de Catalão (Minas Gerais) são compostas pelos complexos Catalão I e II. Catalão I consiste em um plug de cerca de $6 \mathrm{~km}$ de diâmetro que compreende um núcleo de carbonatito cercado por piroxenitos, peridotitos serpentinizados e glimmeritos. Segundo Oliveira e Ibernon, 1998, o perfil laterítico típico descrito em Catalão compreende da base para o topo a rocha fresca que se altera gradualmente para rocha alterada, saprolito isalterítico e saprolito aloterítico (Figura 1.3). O processo de intemperismo altera a coloração da rocha original e seu nível de agregação. O perfil é coberto então por uma camada de recapeamento para-autóctone (solo).

Em Catalão, a rocha fresca da base do perfil consiste de uma densa rede de foscoritos e carbonatitos intrusivos em bebedouritos metassomatizados (flogopititos) em graus variados. A rocha alterada consiste de flogopititos e foscoritos levemente alterados, ainda cortados pelos veios de carbonatito. O saprolito isalterítico mantém a textura e estrutura da rocha original, com diferentes graus de alteração e agregação. Em Catalão foram observados também no saprolito isalterítico porções mais silicificadas e alguns níveis de concreções 
ferruginosas. O saprolito aloterítico é mais homogêneo, composto por material mais desagregado, onde não são mais observadas as estruturas e texturas da rocha original. O recapeamento ou solo é argiláceo e apresenta um contato abrupto com o saprolito isalterítico.

Oliveira e Imbernon (1998) definem uma sequência de laterização para Catalão que começa com a dissolução dos carbonatos sem deixar resíduo. O ambiente empobrecido em Ca se torna mais ácido, desestabilizando a apatita e iniciando a alteração dos minerais silicáticos (Oliveira e Imbernon, 1998; Toledo, 1999; Toledo et al., 2004b). Relictos de apatita ígnea, eventualmente recobertos por apatita secundária, são encontrados no saprolito isalterítico (Morteani e Preinfalk, 1996), indicando uma maior estabilidade em relação ao carbonato. Fases neoformadas compreendem goethita, quartzo e aluminofosfatos. A diferença de susceptibilidade dos minerais primários ao intemperismo define a boa estratificação e a mudança de estrutura no perfil laterítico. O horizonte isalterítico é definido pela eliminação do carbonato, sendo o volume nesse horizonte suportado principalmente por apatita. Quando a apatita é alterada, a estrutura da rocha colapsa formando o horizonte aloterítico. Especula-se que o topo do horizonte aloterítico, de composição caolinítica, foi formado a partir de uma contribuição de fases alóctones mais ricas em alumínio.

Do ponto de vista geoquímico, a alteração é tipicamente laterítica com remoção de $\mathrm{Ca}, \mathrm{Mg}, \mathrm{K}$ e Si e acumulação de Fe e Ti. O P apresenta um comportamento específico, se concentrando em zonas intermediárias ricas em apatita. Quando a apatita é desestabilizada, parte do $\mathrm{P}$ é fixado em fosfatos aluminosos secundários, e o restante é removido. Concentrações locais de Si são interpretadas como resultado da remoção parcial deste elemento do sistema em um ambiente de drenagem restrita, processo relativamente comum em lateritas geradas a partir de rochas empobrecidas em Al (Oliveira et al, 1992). Oliveira e Imbernon (1998) especulam que o acúmulo de Fe é dependente do volume de pirita, posteriormente alterada, encontrado na rocha fresca.

Toledo et al. (2004b) classificam as apatitas de Catalão I em três grupos principais: primárias, pós-magmáticas/hidrotermais e supergênicas. As apatitas primárias são fluorapatitas com teores significativos de $\mathrm{ETR}_{2} \mathrm{O}_{3}$ (até 1,5\% em peso por WDS). Apatitas primárias que sofrem processo de intemperismo apresentam baixo fechamento nas análises de WDS, sugerindo presença de carbonato ou hidroxila em sua estrutura, maiores teores de 
F e menores teores de cátions substituintes do Ca. Apatitas pós-magmáticas/hidrotermais ocorrem como bordas de mais alta birrefringência, bandamentos e agregados de cristais tabulares sempre associadas às apatitas primárias. Apresentam composições variáveis, mas são em geral enriquecidas em $\mathrm{SrO}, \mathrm{Na}_{2} \mathrm{O}$ e $\mathrm{ETR}_{2} \mathrm{O}_{3}$. Apatitas neste grupo apresentam os maiores teores analisados de $\mathrm{SrO}$ e $\mathrm{Na}_{2} \mathrm{O}, 11,3 \%$ e $0,32 \%$ respectivamente. Apatita intempérica é encontrada no material alterado, em fissuras e agregados de plasma secundário de morfologia fibro-radial e globular. São fluorapatitas, com teores menores de $\mathrm{SrO}$ (até $0,87 \%$ em peso, por WDS) e presença de $\mathrm{MgO}$ e $\mathrm{BaO}(<0,8 \%$ em peso, por WDS), no caso da apatita do tipo globular.

O enriquecimento residual econômico de pirocloro ocorre no saprolito isalterítico de acordo com Fava (2001). Na aloterita, o nióbio é complexado em diversos hidróxidos de ferro, não permitindo seu aproveitamento econômico.

O comportamento dos ETR no perfil de alteração é relativamente complexo e motivo de controvérsias. Há indicações de que, após sua liberação dos minerais primários, os ETR podem ser mobilizados e, em alguns casos, fracionados durante o intemperismo. Em geral, o perfil de alteração apresenta um enriquecimento em ETR da base para o topo do perfil de alteração, com baixa diferenciação e praticamente o mesmo padrão de distribuição da rocha fresca (Imbernon et al., 1994; Morteani e Preinfalk, 1996; Oliveira e Imbernon, 1998). As zonas silicificadas muito ricas em ETR podem ser resultado combinado de contribuição hipogênica e também supergênica (Neumann e Lapido-Loureiro, 1993; Neumann, 1994; 1999; Oliveira e Imbernon, 1998). O principal portador de ETR em bebedouritos frescos de Catalão I é a perovskita. A perovskita dos cumulados bebedouríticos é alterada para anatásio durante uma fase de alteração hidrotermal (Pereira et al., 2005) ou carbohidrotermal (Ribeiro, 2008), com incorporação dos ETR no fluido e sua posterior precipitação na forma de monazita com alguns núcleos de cerianita, o que a distingue da monazita supergênica, formada nos horizontes isalterítico e aloterítico. Essa monazita de origem carbohidrotermal é estável durante o intemperismo e pode apresentar grande concentração residual, com teores acima de $10 \%$ de $\mathrm{ETR}_{2} \mathrm{O}_{3}$ (Ribeiro, 2008). Os altos teores podem ainda indicar que os ETR foram aprisionados pelos fosfatos durante a precipitação da sílica, provavelmente pela alteração das condições de pH (Morteani e Preinfalk, 1996). 
Os teores de ETR são maiores em carbonatitos que em foscoritos (Oliveira e Imbernon, 1998) nas rochas frescas. A alta razão La/Lu normalizada dos carbonatitos indica um alto grau de fracionamento entre terras raras leves e pesadas. A partir do desenvolvimento do perfil laterítico o acúmulo de ETR tende a se intensificar. O conteúdo de ETR aumenta em direção ao topo do perfil laterítico com exceção da cobertura de solo, e de forma relativamente homogênea (todos os ETR). O paralelismo nas curvas de ETR normalizadas ao condrito das amostras do perfil de intemperismo e das amostras de rocha fresca indica um incipiente fracionamento durante o intemperismo (Figura 1.4), e se reflete na pequena variação da razão La/Lu entre as amostras do perfil. Oliveira e Imbernon (1998) apontam apatita como o principal mineral portador de ETR em foscoritos e carbonatitos frescos de Catalão. Trata-se de uma fluorhidróxi-apatita com conteúdo médio de $\mathrm{REE}_{2} \mathrm{O}_{3}$ de $0,85 \%$ e razão La/Lu normalizada de 318, indicando um enriquecimento em ETR leves. Pirocloro e perovskita, também portadores de ETR, não foram observados por Oliveira e Imbernon (1998), mas pirocloro com até $6 \%$ de $\mathrm{ERTR}_{2} \mathrm{O}_{3}$ ocorre em nelsonitos e carbonatitos próximos da porção central do complexo, no depósito de Nb (Cordeiro et al., 2011). Morteani e Preinfalk (1995) observaram também carbonatos portadores de ETR, porém menos enriquecidos nesses elementos do que a apatita. No horizonte isalterítico o aumento dos teores de ETR se deve à concentração relativa de apatita. Quando a apatita é alterada os ETR são prontamente incorporados pelos aluminofosfatos neoformados. Foram observados óxidos e hidróxidos de Fe e Mn contendo teores de ETR. Algumas amostras silicificadas apresentam altos teores de ETR $(2,48 \%$ e $4,83 \%)$ e razão La/Lu extremamente alta (>2000). 

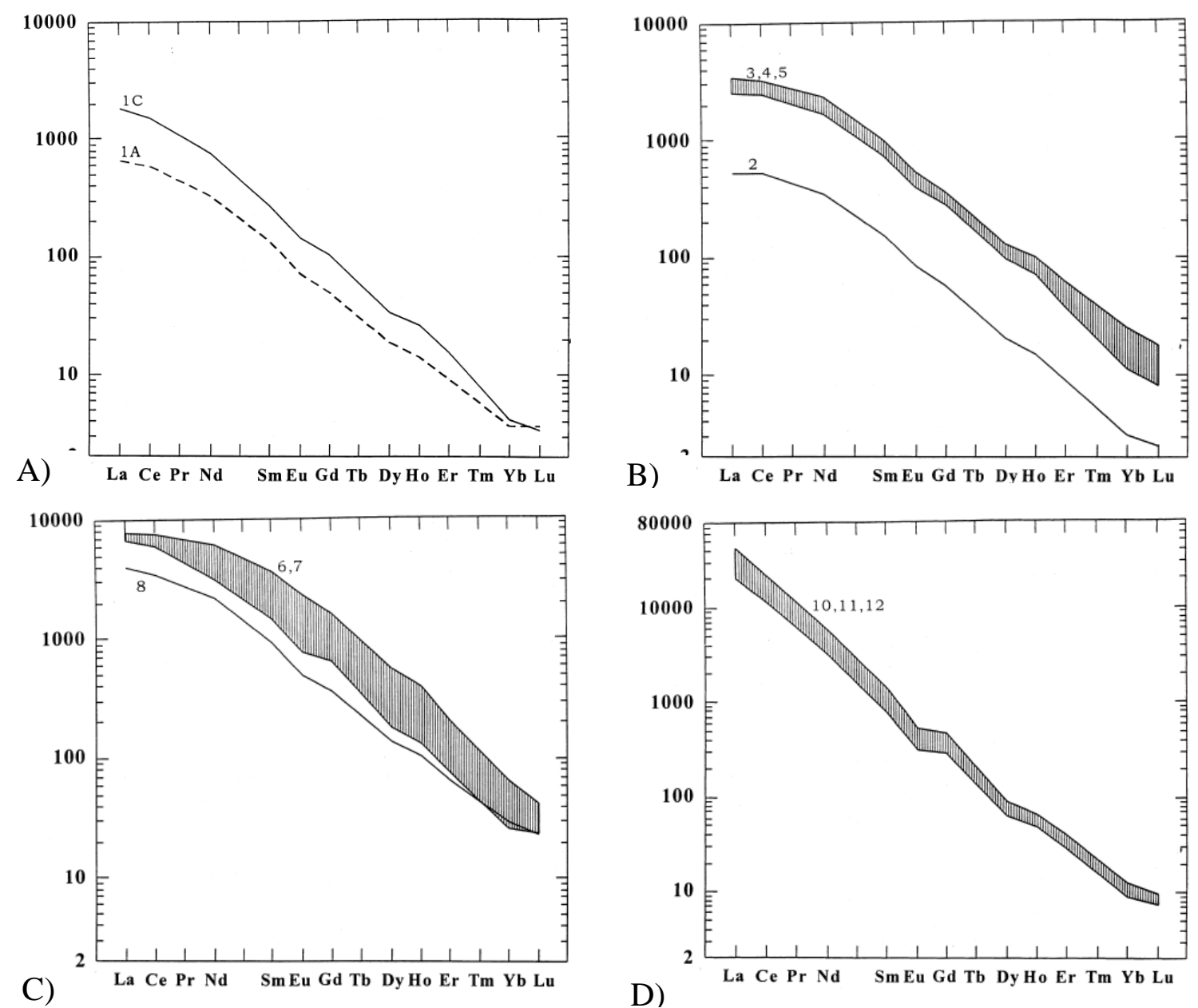

Figura 1.4: Padrões de ETR em Catalão, normalizados para Condrito: A) rocha fresca, foscorito (1A) e carbontito (1C); B) rocha alterada (2) e saprolito isalterítico (3, 4 e 5); C) saprolito aloterítico (6 e 7) e solo (8). D) saprolito silicificado (10, 11 e 12), rico em ETR. Retirado de Oliveira e Imbernon (1998).

Araxá

O perfil laterítico de Araxá é subdividido em 3 unidades principais por Morteani e Preinfalk (1996): uma cobertura de solo no topo; uma zona laterítica sem estrutura da rocha original e localmente com lentes de material argiloso, correlacionável ao saprolito aloterítico de Oliveira e Imbernon (1998); uma zona saprolítica, apresentando estruturas reliquiares da rocha original, correlacionável ao saprolito isalterítico. Araxá apresenta também, no topo do horizonte aloterítico, uma camada de ganga laterítica (duricrust) extremamente dura, logo abaixo da camada de solo. A distribuição dos padrões de ETR nomalizados a condrito indicam que os diferentes horizontes de intemperismo apresentam o mesmo padrão de distribuição das rochas alcalinas subjacentes (Figura 1.5). Apresentam também um 
enriquecimento em ETR de até 1.000x comparativamente à rocha fresca. Não foram encontradas anomalias de $\mathrm{Ce}$ ou $\mathrm{Eu}$.

Morteani e Preinfalk, (1996) descrevem apatita e calcita como os principais portadores de ETR no complexo de Araxá. Em geral, apatitas são mais enriquecidas em ETR que a calcita em cerca de duas vezes. Ambos minerais apresentam o padrão de enriquecimento típico de rochas alcalinas (maior enriquecimento em terras raras leves, alta razão $\mathrm{La} / \mathrm{Lu}$ ). Assim como observado em Catalão, os principais portadores de ETR no saprolito isalterítico são apatitas primárias reliquiares, apatitas secundárias e fosfatos aluminosos (gorceixita). Durante o processo de alteração primeiramente a calcita e depois a apatita são dissolvidas. Apatita primária reliquiar apresenta feições de intensa corrosão. A apatita secundária se desenvolve em fissuras e espaços vazios na rocha, frequentemente associada com cristais de barita. Todas as gerações de apatita são fluorapatitas e apresentam conteúdo diferenciado de ETR: apatitas secundárias são mais enriquecidas que apatitas primárias. Esse enriquecimento é interpretado como resultado da assimilação na estrutura da apatita secundária de elementos terras raras liberados pela dissolução da calcita magmática. Essa assimilação ocorre associada a uma diminuição do conteúdo de $\mathrm{CaO}$, confirmando a substituição entre os elementos. No saprolito aloterítico os fosfatos aluminosos secundários são os principais portadores dos ETR. São eventualmente associados com barita e óxidoshidróxidos de manganês aciculares. Morteani e Preinfalk (1996) ainda consideram os hidróxidos de ferro como portadores de ETR no perfil. Testes de dissolução seletiva indicam que apesar de baixos, volumes significativos de $\mathrm{La}, \mathrm{Ce} \mathrm{Nd}$ e $\mathrm{Y}$ estão associados com os hidróxidos de Fe. 

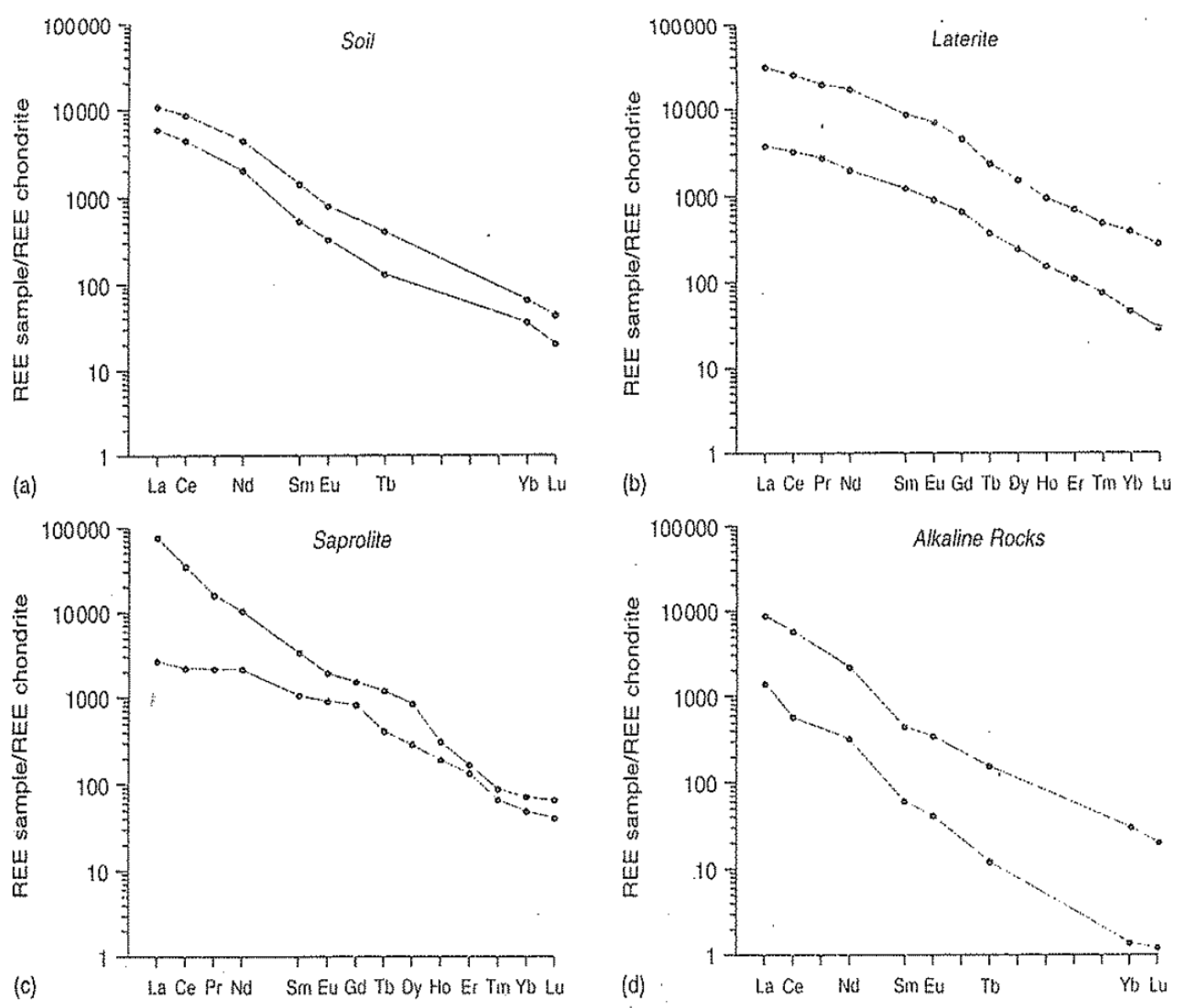

Figura 1.5: Padrões normalizados para Condrito de ETR em Araxá: A) solo; B) saprolito aloterítico/laterita C) saprolito isalterítico/saprolito e D) rochas alcalinas. Retirado de Morteani e Preinfalk (1996).

Conforme observado em Catalão, o processo de laterização não produz nenhum fracionamento consistente dos ETR, com o padrão das amostras alteradas refletindo o padrão da rocha subjacente.

\section{Tapira}

No complexo alcalino carbonatítico de Tapira, localizado em Minas Gerais, o perfil laterítico é originado a partir de piroxenitos e peridotitos contendo apatita e perovskita (Soubiés et al., 1990). Soubiés et al. (1990) estabelecem que num primeiro estágio de alteração isovolumétrica (ou saprolito isalterítico) ocorre a remoção completa da sílica, dissolução parcial da apatita primária e formação de apatita secundária ao longo de fraturas na rocha, enriquecida em flúor e empobrecida em ETR. A perovskita é transformada pseudomorficamente em anatásio microbotrioidal, associada ao aparecimento de geodos de 
minerais de ETR do grupo do rabdofano $\left[(\mathrm{Ca}, \mathrm{REE}) \mathrm{PO}_{3}(\mathrm{O}, \mathrm{OH}) \cdot \mathrm{x}\left(\mathrm{H}_{2} \mathrm{O}\right)\right]$. Um segundo estágio de alteração envolve a dissolução de todas as apatitas, deixando vazios estruturais que posteriormente colapsam. Os minerais de ETR do grupo do rabdofano são parcialmente dissolvidos e substituídos por fosfatos aluminosos do grupo crandalita $(\mathrm{Ca}, \mathrm{REE})(\mathrm{Al}, \mathrm{Fe})^{3+}\left(\mathrm{PO}_{4}\right)\left(\mathrm{PO}_{3}\right)(\mathrm{O}, \mathrm{OH})(\mathrm{OH})_{6}$. Soubiés et al (1990) ainda indicam que nessa segunda fase de alteração ocorre uma mobilização parcial do titânio no interior do anatásio, sua epigenetização por produtos ferruginosos e a alteração inicial da titano-magnetita.

Em Tapira o processo de intemperismo permite também a acumulação residual de pirocloro, formando depósitos consideráveis (113Mt @ 0,48\% $\mathrm{Nb}_{2} \mathrm{O}_{5}$, Melo, 1997) embora com teores expressivamente menores dos que os encontrados em Catalão e Araxá. Brod (1999) não descreve em Tapira nelsonitos semelhantes aos de Catalão 1 e 2, responsáveis pela mineralização primária de pirocloro. Assim como em Salitre (Barbosa, 2009) a mineralização de pirocloro de Tapira está disseminada em carbonatitos.

\section{Juquiá}

No complexo alcalino carbonatítico de Juquiá (São Paulo), o perfil laterítico é dividido em três horizontes específicos: rocha fresca ou inalterada, saprolito ocre (estruturas da rocha original preservadas) correlacionável ao isalterito, e uma camada avermelhada rica em material fino, sem estruturas preservadas, correlacionável a aloterita. Walter et al., (1995) concentram seus estudos nos horizontes de rocha fresca e saprolito ocre. A partir de separação de líquidos densos e micro amostragem, obtiveram concentrados puros ou quase puros das diferentes fases minerais que compõem o perfil, para análise química por via úmida e por microssonda eletrônica.

Walter et al. (1995) definem para Juquiá quatro tendências de alteração laterítica distintas, com respectivas suítes de minerais secundários e texturas específicas: alteração da dolomita, apatita, flogopita e magnetita (Figura 1.6). Na parte inferior do saprolito, cristais dissolvidos de dolomita são substituídos por goethita e produtos amorfos de Mn e Fe, numa matriz dura associada à apatita. Observam, também, calcita secundária em pequenas fissuras no topo da rocha fresca, indicando uma movimentação descendente de $\mathrm{Ca}$ e algum $\mathrm{Mg}$ em direção à rocha fresca. Os produtos de alteração amorfos de $\mathrm{Mg}$ e Fe são mais enriquecidos 
em ETR em direção ao topo do perfil, enquanto a calcita é depletada em ETR em relação à dolomita primária. No trend de dissolução da apatita, apatitas primárias são dissolvidas e reprecipitadas em tipos distintos diferenciados de apatitas secundárias, evidenciadas por relações texturais, análises químicas e por isótopos de carbono e oxigênio. A primeira geração de apatitas secundárias é formada por carbonato-fluorapatitas aciculares, associadas à apatita primária e à massa amorfa de hidróxidos de ferro e manganês. Com a progressão da laterização, apatitas primárias são completamente lixiviadas, precipitando uma nova geração de apatitas associadas a carbonato-fluorapatita. Em geral, apatitas tardias são empobrecidas em ETR e suas curvas de distribuição indicam um enriquecimento em ETR leves e uma pequena anomalia negativa em Ce. A carbonato-fluorapatita apresenta teores e padrão de distribuição similar aos da apatita primária e uma pequena anomalia positiva em Ce. Os níveis ricos em flogopita, quando alterados, formam lentes de material poroso composto pela associação goethita e gorceixita, com apatita e barita reliquiares. A gorceixita também ocorre como pseudomorfos a partir de flogopita. Fissuras são cobertas por agulhas de wavelita. Elementos terras raras são enriquecidos nos dois tipos de gorceixita analisados. Finalmente, o trend de alteração da magnetita define sua alteração para uma mistura de goethita e hematita, com presença de Ti, Mn e Ba.
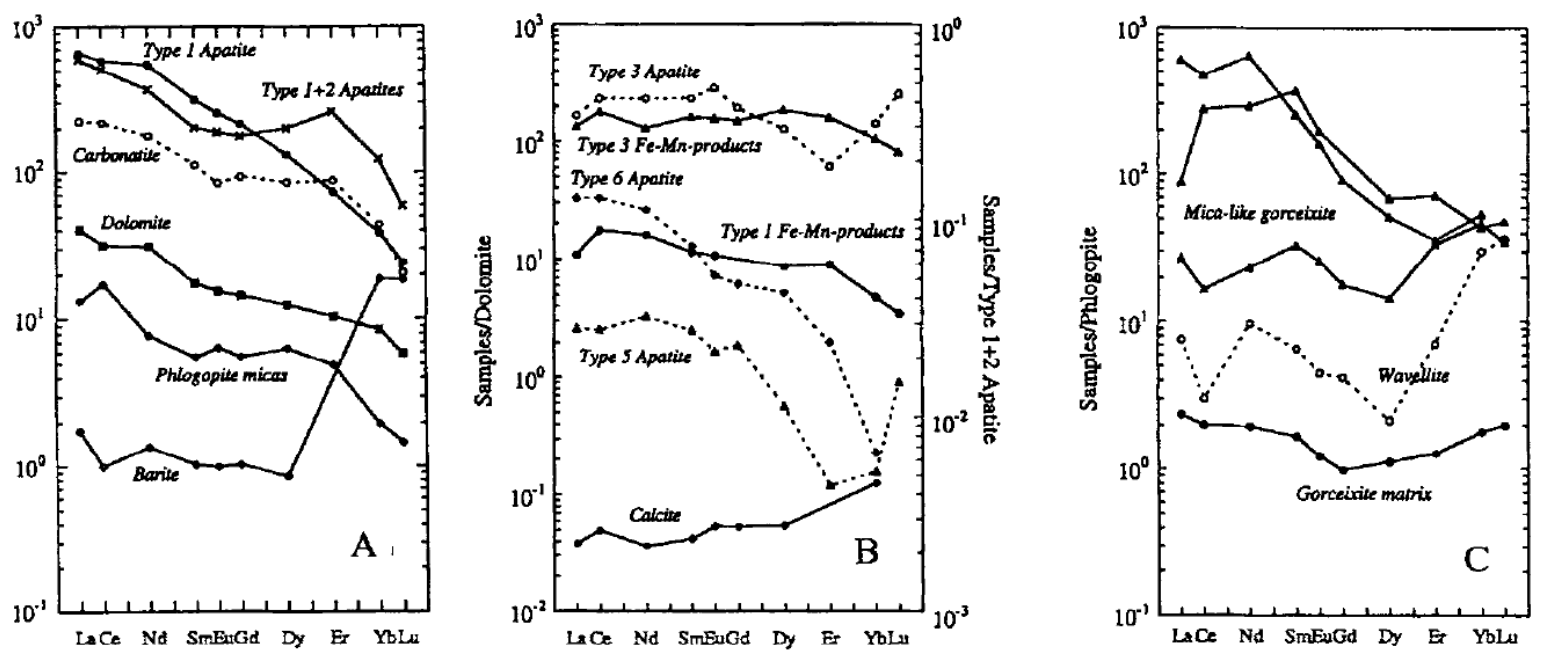

Figura 1.6: Análises de ETR para minerais de Juquiá: A) padrões normalizados a Condrito dos minerais primários: apatita 1 e 2, carbonato e dolomita, flogopita e barita; B) padrões normalizados a dolomita dos minerais secundários, hidróxidos de Fe e Mn e calcita; C) padrões normalizados a flogopita dos minerais secundários gorceixita pseudomórfica, gorceixita amorfa e wavelita. Retirado de Walter et al, 1995. 
O perfil laterítico de Juquiá é enriquecido em carbonatos e fosfatos e empobrecido em silicatos de alumínio e minerais de terras raras. Em perfis de intemperismo convencionais, os argilominerais adsorvem os ETR durante a alteração. No caso dos carbonatitos, produtos de alteração amorfos de $\mathrm{Fe}$ e $\mathrm{Mn}$ mal cristalizados, com alta porosidade e substituições pseudomórficas (gorceixita) podem atuar como armadilhas para os ETR (Walter et al., 1995). Sua geração resulta na preservação do conteúdo e distribuição de terras raras dos minerais primários que estão sendo substituídos. Contudo, a precipitação de minerais secundários em microambientes abertos (microfissuras e vênulas), caracterizados pela alta circulação de fluidos, resulta na depleção ou fracionamento dos ETR em relação aos minerais primários alterados. Minerais secundários e resultados de substituição pseudomórfica concentram os maiores teores de ETR e também são associados ao maior fracionamento ETR leves/pesados. Walter et al. (1995) ainda indicam que a presença de matéria orgânica pode alterar significativamente o balanço e distribuição dos ETR no perfil de alteração.

De maneira geral, o perfil de alteração intempérica nos depósitos da APIP (Araxá, Catalão e Tapira) e em Juquiá, apresenta uma série de similaridades. A partir da dissolução dos minerais primários, elementos como fosfato e terras raras são liberados no sistema e reconcentrados em minerais secundários. $\mathrm{O}$ mineral primário é principalmente a apatita (que também disponibiliza o $\mathrm{P}_{2} \mathrm{O}_{5}$ no sistema). Em Araxá e Catalão, o carbonato contém pequenos teores de ETR e em Tapira, a perovskita é tida como o mineral primário mais importante.

Nos saprolitos isalteríticos, ocorrem apatitas primárias e secundárias como principais portadoras de P. As fases portadoras de ETR nesse horizonte são principalmente minerais fosfatados, do grupo da crandalita em Araxá, Catalão e Juquiá, e rabdofano em Tapira. A gorceixita é microcristalina, apresenta química complexa e ocupa interstícios deixados pela calcita e apatita primárias dissolvidas. Em Juquiá foi encontrada gorceixita pseudomórfica sobre mica, especialmente enriquecida em ETR. Em Tapira ocorrem geodos de rabdofano associados ao anatásio pseudomórfico sobre perovskita. No saprolito aloterítico, a apatita secundária é lixiviada e as fases portadoras de ETR continuam sendo os fosfatos secundários, cada vez mais enriquecidos em Al. Foram observadas também associações de ETR com óxidos-hidróxidos de $\mathrm{Fe}$, Mn e Ba, embora em baixos teores. Em Catalão ocorre ainda monazita nas zonas intensamente silicificadas, responsáveis pelos maiores teores de ETR nesse depósito. 


\subsection{Contexto geológico local}

\subsubsection{Evolução magmática}

O complexo de Salitre, como os outros complexos da APIP, é uma intrusão multifásica formada por rochas das séries bebedourítica, carbonatítica e foscorítica (Figura 1.7). O complexo forma um sistema de intrusões coalescentes (Mariano \& Marchetto, 1991): Salitre I tem forma aproximadamente oval, com cerca de $7 \mathrm{~km}$ na direção N-S e $5 \mathrm{~km}$ na direção E-W. É composto basicamente por bebedourito, tinguaito, traquito, fenito, apatitacarbonatito, calcita carbonatito e foscorito. Ao centro do corpo predominam bebedouritos ricos em perovskita (B1), com ou sem olivina (Barbosa et al, 2012). Na porção sul, bebedouritos ricos em Ti-andradita, piroxênio e flogopita são dominantes, formando uma intrusão independente mais tardia (B2). Dentro da intrusão B1 ocorrem diques de bebedouritos com titanita + Ti-andradita e com perovskita + titanita + Ti-andradita, relacionados à intrusão B2. Dentro do domínio dos perovskita bebedouritos ocorrem rochas carbonatíticas e foscoríticas como um sistema de diques anelares interconectados (Barbosa et al., 2012). Os carbonatitos podem ser dolomíticos ou calcíticos, com presença de olivina, flogopita, magnetita, ilmenita, pirocloro e sulfetos (pirita, pirrotita e calcopirita). Os foscoritos contêm proporções variáveis de olivina, magnetita e apatita (foscoritos, nelsonitos, apatititos e magnetititos), além de flogopita e, como acessórios, pirocloro e sulfetos (pirrotita e calcopirita) (Barbosa et al., 2012).

O corpo de Salitre II, um plug de 2,5 $\mathrm{km}^{2}$ situado entre Serra Negra e Salitre I, contém principalmente rochas ultramáficas (dunito, perovskitito, bebedourito, localmente cortados por diques e veios carbonatíticos). Salitre III é um pequeno corpo a sul de Salitre I, essencialmente formado por piroxenitos, com foscoritos subordinados (Brod et al., 2004). 

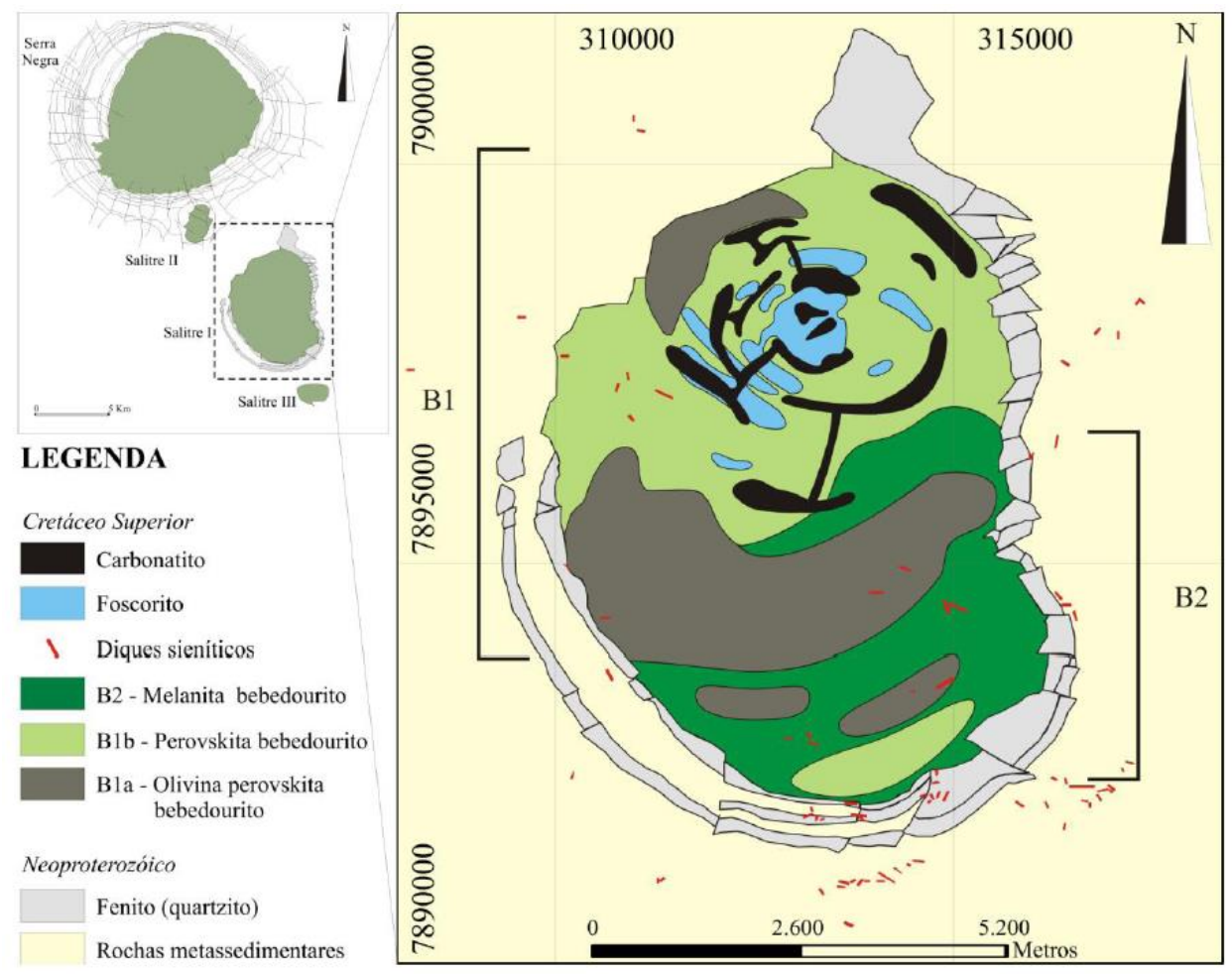

Figura 1.7: Mapa geológico do substrato dos corpos de Salitre I, II e III, com base em furos de sonda e geofísica. As unidades representadas na figura correspondem a zonas de predominância de um determinado tipo litológico e não a zonas homogêneas. Barbosa et al. (2012).

\subsection{Mineralogia de complexos carbonatíticos e mineralização associada}

Hogarth (1985, 1989) estima em 300 os minerais descritos em complexos carbonatíticos, incluindo componentes primários e produtos de alteração. Barker (1989) descreve a mineralogia essencial de carbonatitos, suas texturas mais freqüentes e os elementos-traço associados aos minerais. A calcita é comumente tabular ou apresenta agregados granulares finos e apresenta altos teores de $\mathrm{Sr}$, sendo a solução sólida com dolomita mais comum do que a solução com carbonatos de ferro. A segunda fase mais abundante, os minerais do grupo da apatita, apresentam significativas concentrações de elementos terras raras, silício e sódio. Fenocristais de olivina $(\mathrm{Mg}, \mathrm{Fe})_{2} \mathrm{SiO}_{4}$ e monticellita $\left(\mathrm{CaMgSiO}_{4}\right)$ são raros. Clinopiroxênio varia de $\mathrm{CaMgSi}_{2} \mathrm{O}_{6}$ a $\mathrm{NaFeSi}_{2} \mathrm{O}_{6}$ e é mais abundante em carbonatitos vulcânicos. 
Flogopita e tetraferriflogopita (substituição de $\mathrm{Al}^{3+}$ por $\mathrm{Fe}^{3+}$ no sítio tetraédrico causando pleocroísmo invertido) são muito comuns em carbonatitos. Periclásio $(\mathrm{MgO})$ é raro, e geralmente ocorre na matriz de carbonatitos plutônicos. Perovskita $\left(\mathrm{CaTiO}_{3}\right)$ é rara, e mostra substituição de $\mathrm{Ca}$ por $\mathrm{Na}$ e de $\mathrm{Ti}$ por $\mathrm{Nb}$. A magnetita em grãos euédricos, é o espinélio mais freqüente. Ilmenita ocorre em pequenas proporções, como grãos euédricos. Outros minerais comuns incluem barita, halogenetos e sulfetos.

Carbonatitos são enriquecidos em $\mathrm{Ba}, \mathrm{Nb}, \mathrm{ETR}, \mathrm{Sr}$, Th e U e hospedam alguns dos mais conhecidos (ou potenciais) depósitos minerais de $\mathrm{Cu}, \mathrm{Nb}$, ETRs, fosfato, vermiculita e fluorita. A origem da mineralização em complexos carbonatíticos pode ser primária (magmática), hidrotermal ou supergênica. Mineralizações primárias podem se tornar jazidas econômicas a partir do desenvolvimento de um perfil laterítico que concentra os minerais resistentes, a partir da dissolução e remoção de elementos móveis, especialmente os contidos em carbonatos. Vários artigos resumem as mineralizações econômicas em carbonatitos (e.g. Deans, 1966, Mariano, 1989, Petrov, 2004, Biondi, 2005).

Existe uma grande variedade de minerais que são atualmente extraídos de carbonatitos, como bastnäesita, monazita, apatita, pirocloro, magnetita, fluorita, vermiculita, calcopirita, baddeleíta, torita e uraninita. As commodities obtidas desses minerais incluem os elementos terras raras (ETRs), fosfato, nióbio, cobre, zircônio, tório, urânio, fluorita e vermiculita. Uma ampla variedade de elementos pode ser extraída como subproduto, incluindo Ta, Au, Ag e PGM (Woolley \& Kjarsgaard, 2008).

Importantes depósitos de fosfato estão contidos em complexos alcalinocarbonatíticos. Os minerais do grupo da apatita são os minerais acessórios primários mais comuns nos complexos. Em foscoritos, nelsonitos e apatititos a concentração dos minerais deste grupo pode atingir proporções econômicas já na rocha inalterada.

A decomposição de rochas ricas em minerais do grupo da apatita durante o intemperismo pode concentrar adicionalmente estes minerais, gerando depósitos residuais, como os depósitos de fosfato da APIP. A mineralização primária pode estar associada a carbonatitos e foscoritos, como em Catalão, Salitre e Araxá, ou a rochas silicáticas, como no caso dos bebedouritos de Tapira (Brod et al., 2004). Após a extração da mineralização 
intempérica mais enriquecida, a apatita pode ser obtida por mineração da rocha primária fresca, como em Jacupiranga (Biondi, 2005). Depósitos de fosfato podem ocorrer também a partir de acumulações eluviais, como, por exemplo, em Cargill, Canadá (Sandvik \& Erdosh, 1977).

Carbonatitos e rochas alcalinas associadas constituem a maior fonte de $\mathrm{Nb}$ do mundo. $\mathrm{O} \mathrm{Nb}$ pode estar contido como traços em alguns minerais, como perovskita, rutilo e anatásio, ou pode ocorrer como elemento principal do mineral, como no grupo do pirocloro (Mariano, 1989). As mineralizações de $\mathrm{Nb}$ podem ser primárias e/ou produto de concentração residual por intemperismo, como nos casos de Araxá e Catalão (Brod et al., 2004)

A única mineralização econômica significativa de $\mathrm{Cu}$ em carbonatitos está situada no complexo de Phalaborwa, Africa do Sul (Eriksson, 1989), onde um pipe vertical de foscorito ocorre junto a piroxenitos micáceos, e carbonatitos bandados, que são cortados por carbonatitos tardios ("carbonatito transgressivo"). A mineralização de $\mathrm{Cu}$ consiste dominantemente de bornita primária disseminada entre os tipos de carbonatitos. A mineralização tardia, formada após o carbonatito transgressivo, foi concentrada ao longo de fraturas, e é composta dominantemente por calcopirita. Outros minerais de cobre incluem calcocita, cubanita, cuprita, malaquita e valleriita (Mariano, 1989).

Depósitos de ETR em complexos carbonatíticos ocorrem principalmente a partir de atividade hidrotermal e concentração supergênica, que retrabalham minerais portadores primários (apatita e perovskita, por exemplo). Em Bayan Obo, na China, os principais minerais de minério são monazita, bastnaesita, aeschynita e pirocloro (Campbell, 1997). Raramente, minerais primários de ETR podem estar relacionados a estágios tardimagmáticos, como o caso da mineralização de bastnaesita-parisita em Mountain Pass, Califórnia (Mariano, 1989).

Outras mineralizações/depósitos associados a complexos alcalino-carbonatíticos incluem: vermiculita, oriunda da alteração intempérica da flogopita, que pode ter origem magmática ou metassomática; fluorita, um mineral acessório comum, mas concentrações economicamente significantes estão associadas a atividade hidrotermal tardia; barita, que geralmente está concentrada em estágios tardios na evolução dos carbonatitos, além de se 
concentrar com a atividade hidrotermal em veios e como produto de intemperismo; titânio, associado a laterização de piroxenitos com grandes quantidades de perovskita (como o caso do complexos alcalinos da APIP), convertida em anatásio por descalcificação durante o intemperismo.

Os corpos carbonatíticos da APIP são reconhecidamente os maiores depósitos de anatásio conhecidos. Cerca de $92 \%$ do consumo mundial de titânio deriva de concentrados de ilmenita, concorrendo com outros concentrados minerais (leucoxenio, rutilo e rutilo sintético) para produção de pigmento (Bedinger, 2012). A disponibilização dos recursos de titânio como um co-produto de baixo custo de produção no complexo de Salitre seria um importante agregador de valor no desenvolvimento do depósito.

\subsection{Aspectos texturais e evolutivos do manto de intemperismo em rochas máficas alcalinas e carbonatitos}

Delvigne, (1998) define como intemperismo o processo supergênico que destrói e substitui minerários primários (de origem magmática, metamórfica ou sedimentar) por minerais secundários mais estáveis na parte mais superior da crosta terrestre. Esse processo é geralmente associado com o desenvolvimento de porosidade na rocha. $\mathrm{O}$ autor define ainda como alterito o material do manto de alteração derivado deste processo. Em geral, os minerais formados pela laterização são silicatos, óxidos ou hidróxidos dos elementos mais imóveis (Al, Fe, Ti, Mn, entre outros) hidratados.

A espessura do perfil de solo não excede poucos metros e consiste na parte geralmente exposta do perfil de intemperismo. Em geral o perfil completo pode ter dezenas de metros de espessura quando desenvolvido em condições tropicais húmidas. $\mathrm{O}$ perfil pode ser dividido em diferentes horizontes com importantes diferenças em sua textura e composição mineralógica. Chatelin (1974) propõe a separação do perfil de alteração em aloterita e isalterita, baseando-se principalmente em observações de campo. Dessa forma, Delvigne (1998) divide a maioria dos perfis de alteração, do topo para a base, em solo, aloterita, isalterita, rocha alterada e rocha fresca. $\mathrm{O}$ termo aloterita (do grego alos $=$ diferente) define o horizonte de intemperismo em que as microestruturas herdadas da rocha original não são mais perceptíveis a olho nu. É resultado de um processo externo que progressivamente 
modifica e destrói a estrutura original herdada e preservada nas camadas inferiores. Devido à perda da textura, o volume aparente do material aloterítico é completamente diferente do material original. O horizonte aloterítico é separado da rocha fresca pelo horizonte isalterítico. O termo isalterita (do grego iso = igual ou similar) define o nível de alteração onde a textura e relação espacial entre os minerais da rocha original são preservados. Nos estágios iniciais de intemperismo, mesmo quando os minerais originais são totalmente alterados, as texturas originais se mantêm preservadas. Os minerais originais são transformados ou substituídos por minerais secundários, ou dissolvidos, gerando poros que mantém a forma externa do mineral e, portanto, as relações espaciais da rocha fresca. $\mathrm{O}$ autor ainda aponta que mesmo com a manutenção da textura o volume original não é preservado e comparações devem ser feitas com restrições.

Rochas máficas alcalinas e carbonatitos apresentam algumas texturas específicas típicas durante o processo de intemperismo devido à sua mineralogia característica. Cristais de olivina e piroxênio começam a apresentar aspectos de alteração intempérica em fraturas e clivagens, respectivamente. Cristais de piroxênio apresentam extremidades denticuladas, ocasionalmente circundados pela fase de alteração. A flogopita ou tetraferriflogopita, bastante abundante nos depósitos carbonatíticos da APIP, altera para vermiculita nas primeiras porções do horizonte isalterítico. A vermiculita é considerada um mesoalteromorfo (manutenção da morfologia original com expansão de volume perceptível) da flogopita. Morfologicamente ocorre uma expansão perpendicular às camadas da flogopita original que pode causar o faturamento de cristais adjacentes. A completa desagregação das camadas da flogopita durante a alteração para vermiculita pode gerar kata-alteromorfos (expansão pronunciada de volume; a morfologia e bordas do cristal original não são mais perceptíveis).

Carbonatos apresentam os primeiros sinais de alteração nos planos de sutura entre cristais, progressivamente dissolvidos. A dissolução completa formará koilo-alteromorfos (vazio estrutural cujas bordas mantêm a morfologia do cristal original) com bordas eventualmente evidenciadas pela precipitação de óxidos-hidróxidos de ferro derivados do conteúdo de ferro insolúvel do cristal precursor. Delvigne (1998) indica que o componente residual não deva ultrapassar 2,5\% do volume do mineral original. $\mathrm{O}$ autor ainda aponta que 
o carbonato primário apresenta extremidades denticuladas associadas com a precipitação dos componentes insolúveis. As fases minerais ou o material que preenche os vazios deixados pela dissolução do carbonato são definidos como cumulo koilo-alteromorfos. Em carbonatitos ricos em fosfato, como no complexo alcalino carbonatítico de Juquiá, aglomerados de cristais aciculares de apatita secundária precipitam nos koilo-atlteromofos deixados pela dissolução de ankerita. A morfologia dos cristais de ankerita é preservada nos cumulo-koilo-alteromorfos de apatita que, juntamente com os cristais preservados de apatita ígnea, mantém a textura da rocha no horizonte isalterítico.

A rápida alteração de carbonatos e demais fases minerais também permite a precipitação de alteroplasmas na cavidade resultante. $\mathrm{O}$ alteroplasma (ou plasma de primeira geração) é composto por micropartículas cristalinas secundárias que mantém a forma e volume dos minerais primários. Primeiramente gera uma película na superfície do mineral original que evolui para uma camada mais espessa sempre em direção à parte interna do cristal. O alteroplasma é poroso e pode ser composto por argilas com maior ou menor contribuição de óxidos e hidróxidos de ferro. Ocorre geralmente no horizonte isalterítico. O alteroplasma é substituído por pedoplasmas (plasmas de segunda geração) a partir da evolução do perfil de alteração. A morfologia preservada do grão original pelo alteroplasma é destruída por fragmentação e o material incorporado no plasma secundário de forma progressivamente homogênea. O pedoplasma é composto por partículas de óxidoshidróxidos de ferro ou argilas mais estáveis como kaolinita e ocorre no domínio da aloterita e dos solos.

Óxidos acessórios tipicamente encontrados nos depósitos carbonatíticos também são intemperizados. Anatásio como produto de alteração de perovskita é comum, e corresponde a um holo-alteromorfo (manutenção da morfologia e do volume original). O anatásio gerado é microcristalino e apresenta porosidade não perceptível na escala microscópica.

\subsection{Métodos e amostragem}

As amostras utilizadas na elaboração da presente dissertação foram obtidas a partir de testemunhos de sondagem rotativa do complexo de Salitre I, disponibilizadas pela Vale 
Fertilizantes. A campanha de sondagem foi realizada durante o ano de 2011 e priorizou áreas com maiores indícios de mineralização em ETR e Ti. Foram selecionados e amostrados dois furos de sonda, perfazendo um total de 30 amostras. Ambos os furos encontram-se em porções bebedouríticas e são mineralizados em fosfato, titânio e terras raras, com concentrações consideráveis de nióbio, compreendendo as litologias características do depósito. Foram selecionadas porções de rocha fresca, metassomatizada e principalmente da rocha alterada no mesmo furo, no intuito de obter uma amostragem "vertical" da seção de intemperismo. Análises químicas exploratórias foram utilizadas para determinação das amostras a serem coletadas.

Seções delgadas polidas de cada amostra foram estudadas em luz transmitida e refletida para determinação de composição modal (contagem de pontos) e características texturais. As lâminas delgadas de material intemperizado foram impregnadas ao vácuo com resina plástica, com o objetivo de preservar ao máximo as texturas e estruturas originais da rocha. Análises por difratometria de raios $\mathrm{X}$ foram realizadas para confirmação das fases minerais identificadas na microscopia ótica. A composição química de fases minerais selecionadas (apatita, perovskita, anatásio, pirocloro e fosfatos secundários de ETR) foi determinada por WDS usando uma microssonda eletrônica Jeol JXA-8230 na Universidade de Brasília (UnB). As condições de operação foram de 20 nA e $15 \mathrm{kV}$ para todos os minerais. Para calibração foi utilizado um conjunto de cristais naturais e sintéticos. Estudos de texturas em microscopia eletrônica e análises EDS foram realizados em parceria com o Centro de Desenvolvimento Mineral da Vale em Santa Luzia, Belo Horizonte. Utilizou-se um Microscópio eletrônico de varredura LEO-30 da Phillips, com detector EDS da marca Oxford.

A composição química das amostras foi determinada por ICP-AES (elementos maiores) e ICP-MS (elementos-traço e terras raras), sobre alíquotas fundidas com metaborato de lítio (LiBO4). As análises foram realizadas no laboratório ALS no Canadá. 


\title{
Capítulo 2
}

\section{The weathering profile and the $P$, Ti and REE mineralization of the Salitre alkaline-carbonatite Complex, Central Brazil.}

\author{
Ivan Mendes Caixeta de Pamplona Araújo a , José Affonso Brod b,c \\ $a-I G / U n B ; b-C N P q ; c-I E S A / U F G$ \\ ivanmcparaujo@gmail.com; j.a.brod@gmail.com
}

\section{Abstract:}

The Salitre complex in the Alto Paranaíba Igneous Province (APIP) is an ultrapotassic carbonatite- and phoscorite-bearing alkaline multi-intrusion complex, divided into three main outcropping bodies (Salitre I, II, and III). The weathering profile developed over the complex remobilized and concentrated P, REE and Ti to economic levels. The weathering profile is divided from bottom to top in fresh rock, altered rock, isalterite and alloterite. The fresh rock horizon consists mainly of bebedourite variably affected by $\mathrm{Ca}$-carbonatite metasomatism, with subordinate phoscorite. Perovskite alteration to anatase in fresh rock levels seems to be associated with $\mathrm{Mg}$-carbonatite metasomatism. The isalterite horizon can be divided in Lower Micaceous Isalterite, Upper Micaceous Isalterite and Oxidized Isalterite based on the presence, proportions and morphology of phlogopite-vermiculite and iron oxydeshydroxides. $\mathrm{P}$ mineralization is associated with residual accumulation of igneous apatite in the isalteritic horizon, with minor contribution from secondary apatite. The alloterite horizon is divided in Lower Alloterite and Upper Alloterite. Apatite is not stable in Lower Alloterite, being leached out and replaced by secondary Al-phosphates belonging to the crandallite group. Secondary anatase derived from perovskite alteration accumulates as a residual phase in Lower Alloterite levels, associated with characteristic accumulation of secondary monazite. Secondary monazite is generated from REE liberated from perovskite structure, complexed with available secondary phosphate complexes in the lower alloterite level. Peaks of REE grade are associated with pseudomorphic monazite after carbonate crystals of metasomatic origin.

Keywords: carbonatite, weathering, mineral deposits, monazite, apatite, anatase

\subsection{Introduction}

The Alto Paranaíba Igneous Province (APIP) contains rare examples of ultrapotassic multiphase intrusions formed by associations of phoscorites, carbonatites and alkaline silicate rocks. Besides the petrological interest, this association hosts world class deposits of 
magmatic phosphate and niobium and important occurrences of titanium, rare earth elements, magnetite and vermiculite. All APIP deposits show similarities, such as the ultrapotassic affinity, absence of the ijolite-series and abundance of bebedourite-series rocks. APIP carbonatites span a wide compositional range, but some complexes, such as Catalão I and Araxá, are dominated by magnesiocarbonatite, whereas others (Tapira, Salitre, Serra Negra and Catalão II) are characterized by dominant calciocarbonatite or equilibrated proportions of $\mathrm{Mg}$ and $\mathrm{Ca}$ carbonates. Magnesiocarbonatite-dominated complexes show a higher degree of metasomatism, strong association with phoscorites and high-grade, voluminous, $\mathrm{Nb}$ and REE mineralization; calciocarbonatite-dominated complexes show a lesser degree of metasomatism, their REE and $\mathrm{Nb}$ mineralization known so far is subordinate, but they contain large volumes of Ti (Ribeiro et al., 2014). Both types are mineralized in P but with different petrologic controls, particularly on the magmatic apatite concentrations (Brod et al., 2004, Ribeiro, 2008, Barbosa, 2009, Cordeiro, 2009, Grasso, 2010, Palmieri, 2011). The high intensity of the metasomatism caused by magnesiocarbonatites in Catalão I and Araxá converted most of the primary alkaline silicate rocks (dunites and bebedourites) to metasomatic phlogopitites. Conversely, the less intense calciocarbonatite metasomatism in Salitre and Tapira allowed for a better preservation of the original igneous assemblage, notably bebedourites (Barbosa, 2012).

The weathering profile over the APIP magnesiocarbonatite-dominated complexes was more thoroughly studied in previous works (Morteani and Preinfalk, 1996; Oliveira and Imbernon, 1998; Ribeiro, 2008; Ribeiro et al, 2014) and is known to further concentrate pyrochlore, apatite and REE-bearing minerals. On the other hand, investigation of the weathering profile over the calciocarbonatite-dominated complexes in the province, and their Ti, $\mathrm{P}$ and REE mineralization are scarce. This paper describes the weathering profile over bebedourites of the Salitre I complex, using petrographic, mineral chemistry and whole-rock and alterite geochemistry data, with emphasis on the occurrence and behavior of the $\mathrm{P}, \mathrm{Ti}$ and REE ore-minerals.

\subsubsection{Regional Geological setting}

An intense magmatism that occurred in south-central Brazil and Eastern Paraguay from the Cretaceous to the Eocene was responsible for the emplacement of the Paraná- 
Etendeka flood basalts and the generation of several alkaline provinces at the borders of the Paleozoic Paraná Basin. Over the last three decades, these provinces have been the subject of several field, petrographic, geochemical, isotopic and mineralogical studies (e.g. Woolley, 1987; Gomes et al., 1990; Bizzi et al., 1995; Gibson et al., 1995a, b, 1997; Morbidelli et al., 1995a,b; Comin-Chiaramonti and Gomes, 1996, 2005; Comin-Chiaramonti et al., 1997; Carlson et al., 1996, 2007; Thompson et al., 1998, Brod et al., 2000, 2001, 2004; JunqueiraBrod et al., 2000, 2002, 2004, 2005a,b; Ribeiro et al., 2005). This magmatism is interpreted as the result of the impact of mantle plumes at the base of the continental lithosphere (Herz, 1977; Toyoda et al., 1994; Gibson et al., 1995a, b, 1997; Bizzi et al., 1995; VanDecar et al., 1995; Thompson et al., 1998).

Together with other provinces at the north and northeast border of the Parana Basin, such as Poxoréu, Goiás, and Serra do Mar, the Alto Paranaíba Igneous Province (APIP) is interpreted as the result of the impact of the Trindade Mantle Plume under the lithosphere of central Brazil (Gibson et al., 1995a, 1997; Thompson et al., 1998). The lack of a plumerelated isotopic signature and of a clear array of progressively younger ages along the plume trail has been used as an argument against the involvement of the Trindade plume in the generation of the APIP magmas (Riccomini et al., 2005) but, in their original proposal, Gibson et al. (1995b) point out that the Trindade plume acted only as a heat source for the melting of the overlying sub-continental lithospheric mantle, which explains the lack of plume signature in the APIP magmas. The Nd model ages suggest that a relatively old (0.9$1.3 \mathrm{Ga}$ ) event was responsible for the enrichment of the lithospheric mantle source in the region. Most works report a narrow age range for the province emplacement, between $80 \mathrm{e}$ $90 \mathrm{Ma}$ (Ulbrich and Gomes, 1981; Sonoki and Garda, 1988; Sgarbi et al., 2004).

The APIP comprises a voluminous ultrapotassic magmatism emplaced into Neoproterozoic rocks of the Brasília Mobile Belt. It is situated in a relatively narrow NWtrending area between the SW margin of the Archaean São Francisco Craton and the NE margin of the Paleozoic Paraná Basin. It is composed mainly of kamafugites occurring as numerous small intrusions (plugs, dykes, vents, e.g. Gibson et al., 1995a; Araújo et al., 2001), occasionally ranging up to few hundred meters in diameter, and as lavas and pyroclastic deposits covering large areas (Mata da Corda Group, Seer and Moraes, 1988; Seer et al., 1989; Sgarbi and Valença, 1993, 1994; Sgarbi and Gaspar, 1995; Gibson et al., 1995a). Subordinate amounts of kimberlites (e.g. Gonzaga and Tompkins, 1991; Gibson et al., 1995a; 
Araújo et al., 2001; Costa, 2008) and rare lamproites (Gibson et al., 1995a) also occur in the province. In addition to these volcanic-subvolcanic rock-types, a number of large (up to 65 $\mathrm{km}^{2}$ ) carbonatite- and phoscorite-bearing alkaline complexes occur, comprising Catalão I and II in southern Goiás State, and Serra Negra, Salitre I, II, III, Araxá, and Tapira, in western Minas Gerais State (Berbert, 1984; Gomes et al., 1990; Morbidelli et al., 1995a,b; 1997; Traversa et al., 2001; Brod et al., 2004). These plutonic complexes intrude Neoproterozoic metamorphic rocks of the internal and external domains of the Brasilia Mobile Belt, often producing dome structures.

The presence of xenoliths of dunite, pyroxenite, bebedourite, melilitite, and syenite in the Mata da Corda volcanic and pyroclastic rocks indicates a parental relationship between the APIP kamafugites and the plutonic bebedourites occurring in the APIP complexes (Seer and Moraes, 1988; Lloyd and Bailey, 1991). Brod (1999) and Brod et al., (2000) proposed an ultrapotassic carbonated magma (phlogopite picrite) of kamafugitic affiliation as the parent for both silicate rocks and carbonatites in the APIP plutonic complexes. Phoscoritic rocks have been increasingly described from the APIP plutonic complexes (e.g. Brod et al., 2004; Ribeiro et al., 2005; Fontana, 2006; Cordeiro et al., 2010, 2011), leading to the recognition of a kamafugite-carbonatite-phoscorite association.

Intense tropical weathering and the inward drainage patterns resulting from the weathering-resistant country rock surrounding the domes (Mariano and Marchetto, 1991; Danni et al., 1991) produced a thick weathering cover in most of the complexes, favoring the development of residual and supergenic deposits of phosphate and niobium traditionally exploited in the region, as well as yet unexploited REE, titanium, and vermiculite occurrences. Outcrops are rare, and the best samples for petrographic and geochemical studies are restricted to drill cores and exposures within mining pits.

\subsubsection{Weathering profile}

Weathering profiles developed over carbonatite complexes are abundant in tropical regions (Reedman, 1984; Lottermoser, 1990; Alcover Neto and Toledo, 1993; Angélica and Costa, 1993; Walter et al., 1995; Morteanni and Preinfalk, 1996; Freyssinet et al., 2005). The extent of lateritization is variable, but usually reaches considerable depths (8 to $100 \mathrm{~m}$, Freyssinet et al., 2005). Despite the described complexity, studied weathering profiles exhibit 
a clear vertical mineral zonation (e.g. Oliveira and Imbernon, 1998). Generally, the dissolution of carbonates under tropical climate causes a large volume reduction and residual accumulation of less soluble elements or minerals.

Mass balance calculations are limited due to fresh rock heterogeneity, and to lateral and vertical element mobility, and only a few examples are available in the literature. Boulingui (1997) undertook mass-balance calculations for the entire P-Nb Mabounié deposit in Gabon, showing that $\mathrm{P}$ is highly mobile but over short distances, so that its global content is maintained through the weathering profile as whole. The initial $\mathrm{P}$ mass present in the fresh rock is maintained in the alterite as residual and/or secondary apatite and as aluminumphosphate minerals.

The general weathering profile described on APIP alkaline-carbonatite complexes is usually classified according to the nomenclature proposed by Chatelin (1974) and several following authors (e.g. Altschuler, 1973; Cook, 1984, Morteanni and Preinfalk, 1996; Neumann and Lapido-Loureiro, 1993; Delvigne, 1998; Oliveira and Imbernon, 1998; Brod et al., 2001; Toledo and Pereira 2003; Freyssinet et al., 2005, this work). The underlying fresh rock gradually changes, from bottom to top of the profile, to altered rock, isalterite saprolite, alloterite saprolite and overburden (Figure 2.1). For this work and in accordance to field observations, the isalterite saprolite is sub-divided into three horizons: lower micaceous isalterite, upper micaceous isalterite and Oxidized Isalterite. The alloterite saprolite is subdivided into two levels: lower alloterite and upper alloterite. The upper alloterite covers the entire profile and contains also the soil horizon. The correspondence between this classification and other descriptions of lateritic profiles developed over the APIP alkalinecarbonatite complexes is given in Table 2-1.

The weathering profile over alkaline-carbonatitic occurrences of the APIP presents lithological and mineralogical variations that reflect differences in the fresh rocks from the bebedourite, carbonatite and phoscorite magmatic series (Figure 2.1). In general, rocks of the bebedourite series are the most common, containing variable proportions of Ca-Ti phases (perovskite, Ti-garnet, titanite), olivine, diopside, Al-phlogopite, with minor magnetite, ilmenite and apatite. Variable proportions of apatite, magnetite and olivine or phlogopite to tetraferriphlogopite mica characterize the phoscorite series, spanning a composition range from phoscorites to nelsonites, even apatitites and magnetitites. 
Table 2-1: Classification of the weathering profile proposed in this work compared with the classification of Grasso (2015), Oliveira \& Imbernon (1998) and Ribeiro (2008).

\begin{tabular}{|c|c|c|c|c|}
\hline \multicolumn{2}{|c|}{ Catalão I } & \multirow{2}{*}{\multicolumn{2}{|c|}{$\begin{array}{c}\text { Barreiro } \\
(\text { Grasso, 2015) }\end{array}$}} & \multirow{3}{*}{$\begin{array}{c}\text { Salitre } \\
\text { Present work } \\
\text { Upper Alloterite }\end{array}$} \\
\hline $\begin{array}{c}\text { (Oliveira e Imbernon, } \\
\text { 1998) }\end{array}$ & (Ribeiro, 2008) & & & \\
\hline Overburden & \multirow[b]{2}{*}{ Alloterite } & 4 & Overburden & \\
\hline Alloterite Saprolite & & 3 & Alloterite & Lower Alloterite \\
\hline \multirow{5}{*}{ Isalterite Saprolite } & \multirow{2}{*}{ Oxidized Isalterite } & $2 \mathrm{c}$ & Oxidized Isalterite & Oxidized Isalterite \\
\hline & & $2 b$ & $\begin{array}{l}\text { Top Micaceous } \\
\text { Isalterite }\end{array}$ & $\begin{array}{c}\text { Upper Micaceous } \\
\text { Isalterite } \\
\end{array}$ \\
\hline & Oxidized Micaceous Isalterite & & & \\
\hline & Top Micaceous Isalterite & $2 a$ & $\begin{array}{l}\text { Base Micaceous } \\
\text { Isalterite }\end{array}$ & $\begin{array}{l}\text { Lower Micaceous } \\
\text { Isalterite }\end{array}$ \\
\hline & Base Micaceous Isalterite & & & \\
\hline Altered Rock & Altered Rock & 1 & Altered Rock & Altered Rock \\
\hline Fresh rock & Fresh rock & 0 & Fresh rock & Fresh rock \\
\hline
\end{tabular}

The carbonatite series comprises calciocarbonatites and magnesiocarbonatites, with minor olivine, tetraferriphlogopite, apatite and accessory Sr- and REE-bearing minerals (strontianite and monazite, mostly). All these rocks are frequently metasomatized by latestage carbonatite intrusions, accountable for the alteration of the primary silicates (olivine, diopside and Al-phlogopite) to tetraferriphlogopite. Other common metasomatic mineral transformations include perovskite to anatase and $\mathrm{Mg}$-Fe-carbonates to magnesite (Figure 2.1).

The Altered Rock horizon displays the first, still incipient signs of chemical weathering. Carbonate minerals are still present but show features of dissolution and replacement mostly by iron oxide-hydroxides (Delvigne, 1988). $\mathrm{K}^{+}$is partially removed from Al-phlogopite and tetraferriphlogopite, generating vermiculite and interstratified clay minerals (Oliveira and Imbernon, 1998). This transformation is often incomplete. Other mafic minerals such as clinopyroxene and olivine begin to weather to smectite-group minerals and serpentine. The apatite content is still that of the original igneous/metasomatic rock. Monazite and anatase found at this stage are also from igneous/metasomatic origin. The color of this unit is typically light to bright green.

The Isalterite Saprolite preserves different levels of parental rock texture and structure, despite the abundant development of weathering minerals. Occasionally, intrusive breccia or horizontal layered structures are observed. The color varies from green at the bottom to orange-brown at the top of this unit. The profile is composed mostly of vermiculite, smectite, inter-stratified clays and iron oxide-hydroxides derived from the weathering of 
phlogopite and other mafic minerals. Original igneous/metasomatic apatite is residually concentrated in this unit, in addition to newly formed supergenic apatite, deposited in interstices, fractures and cavities. Other important phases are anatase, residually concentrated from metasomatic rocks as well as derived from the weathering of perovskite, and residual magnetite, ilmenite and pyrochlore.

The Isalterite Saprolite is commonly sub-divided in three levels, according to field observations regarding the amount and type of phyllosilicates: Lower Micaceous Isalterite (abundance of phlogopite-like micas), Upper Micaceous Isalterite (mostly clay minerals, vermiculite, absence of phlogopite-like micas) and Oxidized Isalterite (minor or absent clay minerals, large amount of iron oxide-hydroxides) (Ribeiro et al, 2014). The Isalterite Saprolite contains the phosphate ore, characterized by high concentrations of residual and/or newly formed apatite (Oliveira and Imbernon, 1998; Ribeiro, 2008; Figure 2.2).

The Alloterite saprolite no longer preserves the original structure and is extremely friable. It varies from yellow with banded ochre clays at the bottom to red in the upper portions of the profile. Weathering-resistant minerals (mostly magnetite, ilmenite, anatase and some pyrochlore) are dispersed in a matrix of kaolinite, goethite and iron oxidehydroxides. There is residual accumulation of anatase, leading to the formation of $\mathrm{Ti}$ deposits. Apatite is no longer stable, being replaced by secondary phosphates such as monazite (Toledo and Pereira, 2003) and aluminum phosphate minerals of the crandallitegroup (Oliveira and Imbernon, 1998; Freyssinet et al., 2005). Mn oxides and kaolinite are present. The top of the alloterite saprolite is enriched in goethite and hematite, and may develop oxide concretions and nodules (Freyssinet et al., 2005). In this work, the Alloterite Saprolite is sub-divided in two levels, lower alloterite and upper alloterite. Anatase (Ti) and pyrochlore $(\mathrm{Nb})$ residual concentrations might reach economic importance within the alloterite saprolite (Figure 2.2) (Brod, 2001; Freyssinet et al., 2005; Cordeiro et al., 2011). Al-bearing phosphates might pseudomorphically replace pyrochlore on superficial sections of the profile (Freyssinet et al., 2005). REE-bearing minerals (monazite, Al-phosphates such as florencite) residual accumulation within the alloteritic horizon are significative. 


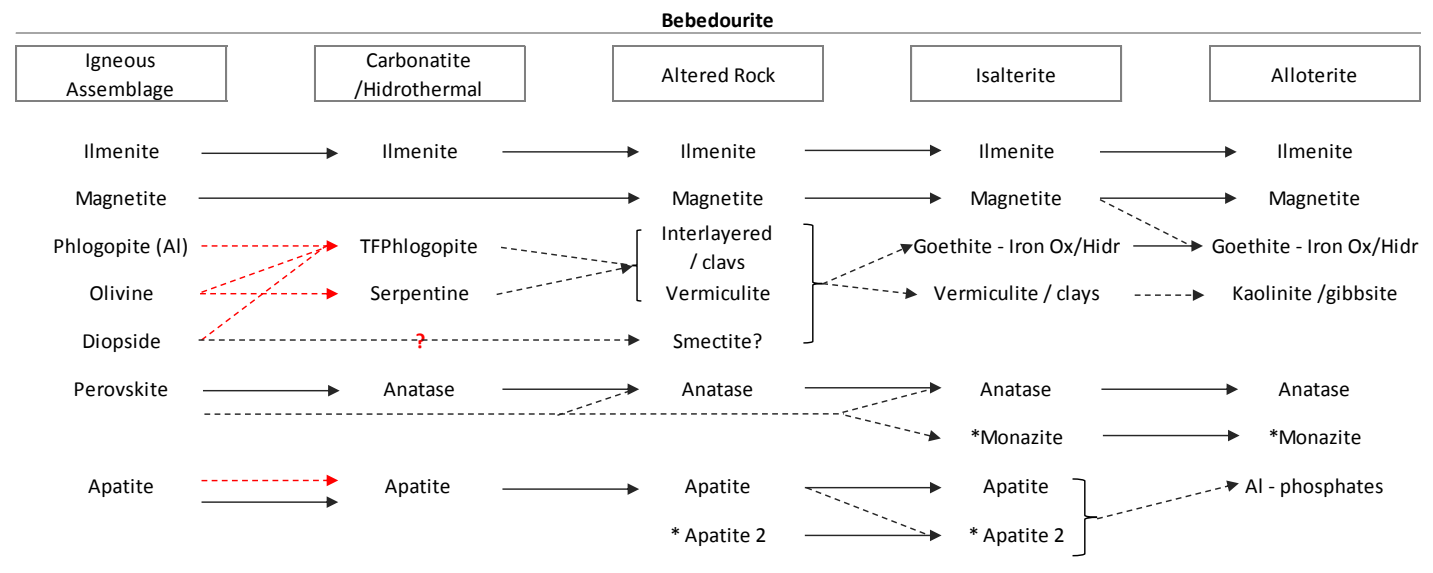

Ti-garnet/Titanite

Phoscorite

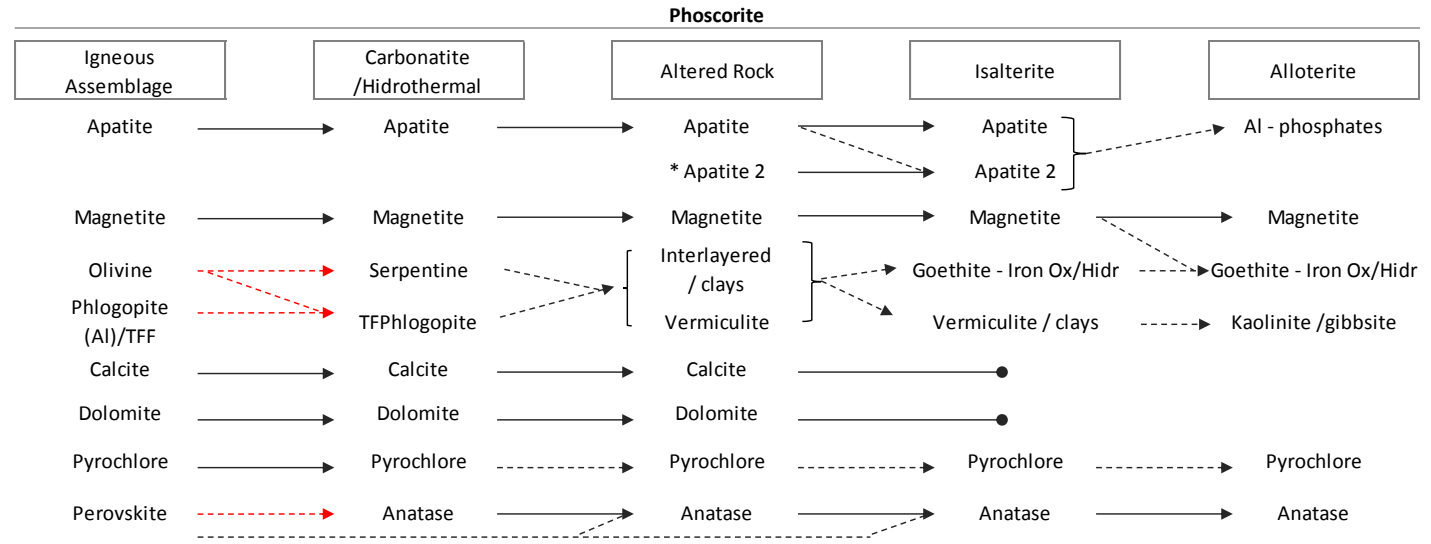

Carbonatite

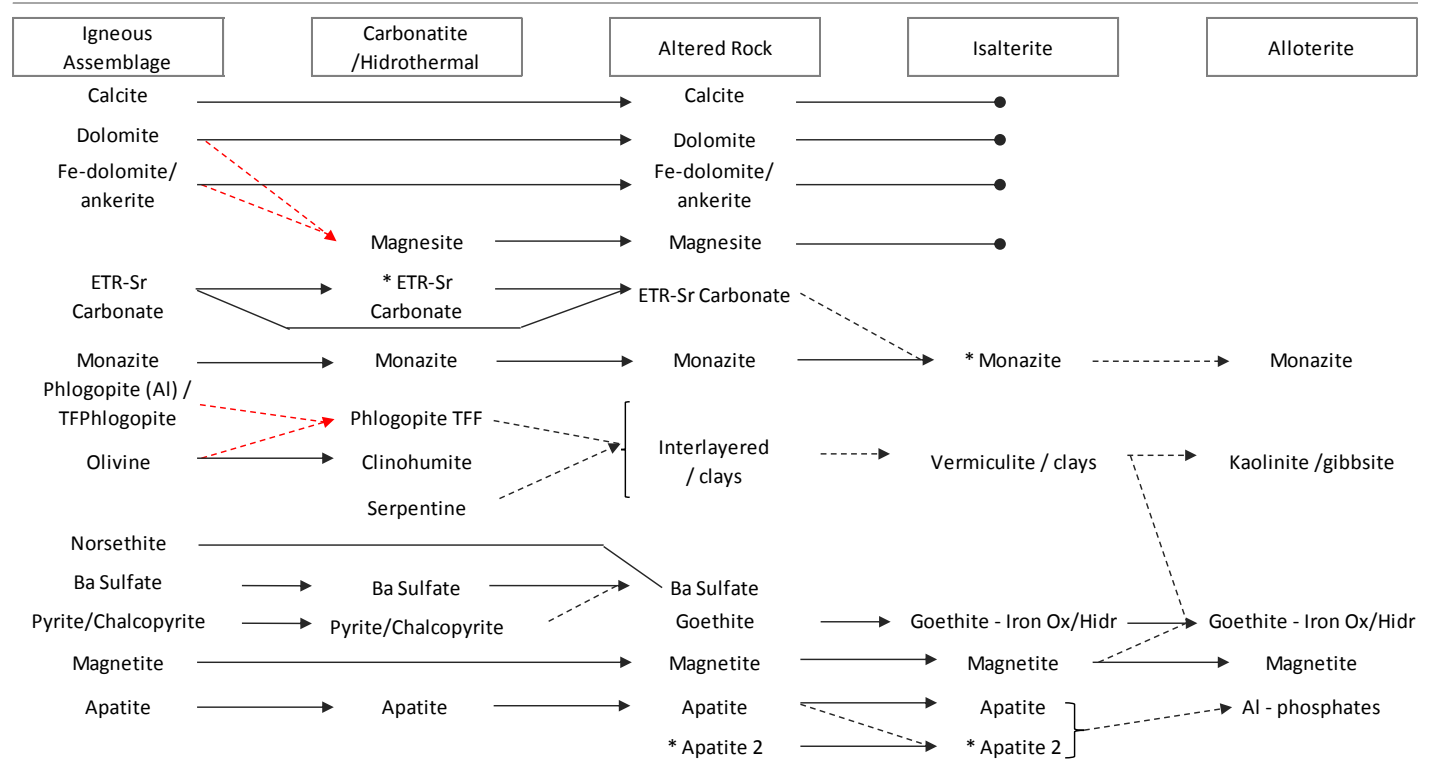

Figure 2.1: Schematic mineralogy of the weathering profile derived from bebedouritic, phoscoritic and carbonatitic series in Brazilian carbonatites. Straight arrows represent minerals that remain unchanged during metasomatism/weathering, dotted arrows represent respective mineral alteration. Red indicates metasomatism and black indicates weathering. (*) indicates minerals formed due to precipitation/nucleation of weathering solutions. Data from Morteani and Preinfalk (1996), Delvigne (1998), Oliveira and Imbernon (1998), Wilson (1999), Brod (2001), Toledo and Pereira (2003), Wilson (2004), Freyssinet (2005), Ribeiro (2008), Azzone and Rubertti (2010), Barbosa (2012). 
The weathering profile over APIP complexes generates a geochemical signature that directly reflects the weathering pattern and residual concentration. For Catalão and Araxá, Morteanni and Preinfalk (1996) observed two weathering trends: enrichment of $\mathrm{Al}_{2} \mathrm{O}_{3}$ associated with depletion of $\mathrm{Fe}_{2} \mathrm{O}_{3}$ and $\mathrm{SiO}_{2}$ in alloterites and a strong enrichment of $\mathrm{Fe}_{2} \mathrm{O}_{3}$ in isalterite samples. The isalterite contains the highest $\mathrm{P}_{2} \mathrm{O}_{5}$ values within the deposit. Oliveira and Imbernon (1998) also described the removal of $\mathrm{MgO}$ and $\mathrm{K}_{2} \mathrm{O}$ during lateritization, with $\mathrm{P}_{2} \mathrm{O}_{5}$ concentration within the isalterite saprolite of Catalão I. Silicified levels are correlated with minor proportions of $\mathrm{P}_{2} \mathrm{O}_{5}$ and $\mathrm{Fe}_{2} \mathrm{O}_{3}$, where all other elements are depleted due to high amounts of $\mathrm{SiO}_{2}$. The described alloterite horizon is characterized by high contents of $\mathrm{Fe}_{2} \mathrm{O}_{3}, \mathrm{TiO}_{2}$, and low $\mathrm{CaO}$, while $\mathrm{P}_{2} \mathrm{O}_{5}$ grades are lower than in the isalterite profile. Normalized trace element diagrams indicate similar patterns between fresh rocks and altered products, showing increase in less soluble elements $(\mathrm{Nb}$ and $\mathrm{Zr}$ ) and $\mathrm{REE}$ in the weathered samples (except for the overburden).
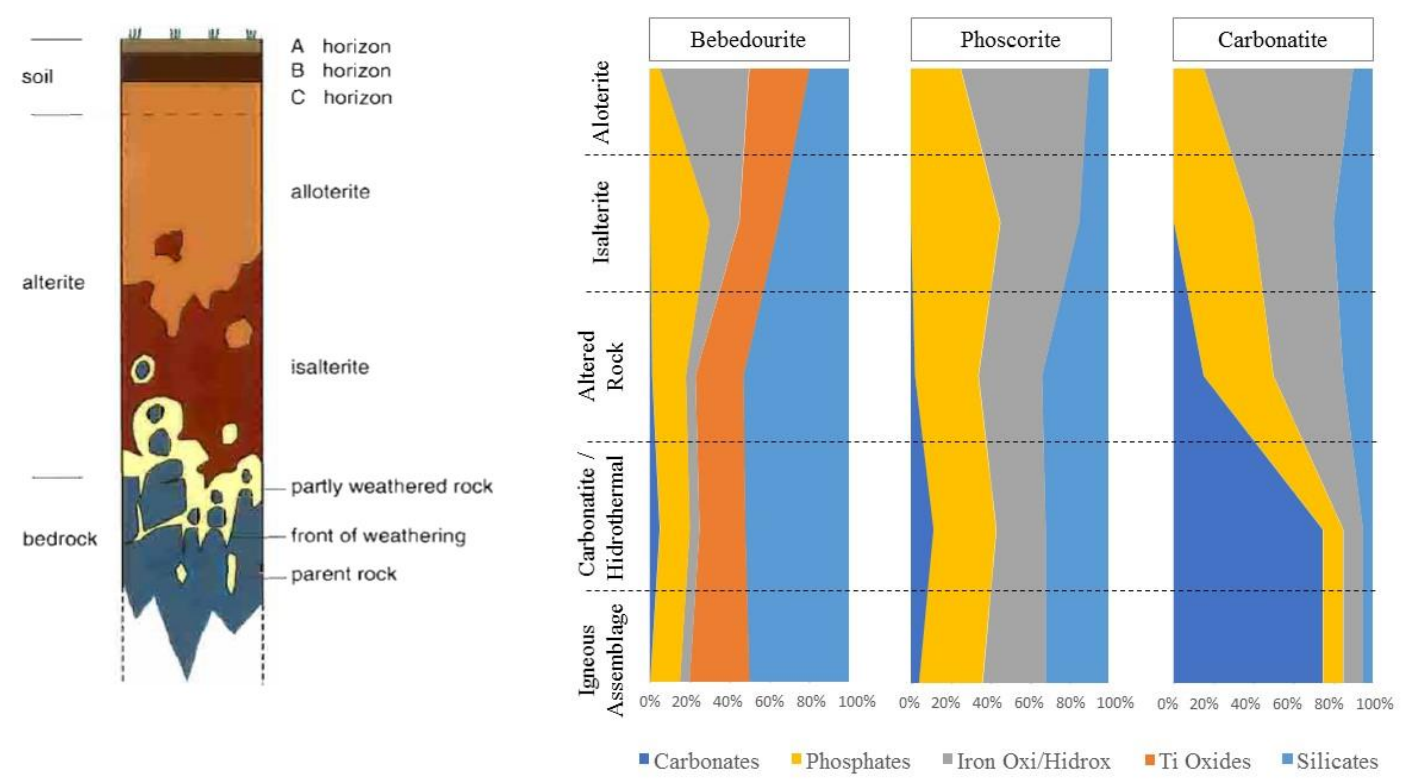

Figure 2.2: Distribution of the different levels and horizons in a typical lateritic profile (Delvigne, 1996) and average modal composition of main mineral groups for main rock systems of the APIP deposits.

\subsubsection{Salitre Complex Geology}

The Salitre I, II, and III intrusions are located south of the Serra Negra Complex in the Patrocínio region, Minas Gerais State, (Figure 2.3). Salitre I is the largest intrusion, 
approximately $7 \mathrm{~km} \mathrm{~N}-\mathrm{S}$ and $5 \mathrm{~km} \mathrm{E-W.} \mathrm{Salitre} \mathrm{II} \mathrm{and} \mathrm{III} \mathrm{are} \mathrm{smaller} \mathrm{round} \mathrm{intrusions} \mathrm{(} \mathrm{2.5}$ $\mathrm{km}^{2}$ ) respectively northwest and southeast of Salitre I. Gomes et al, (1990) compiled K/Ar ages for the Salitre complex in the range of 79-94.5 Ma. Morbidelli et al., (1997) concluded that the preferred age for Salitre is $82 \mathrm{Ma}$, while Comin-Chiaramonti et al. (2005) give an average age of $84 \mathrm{Ma}$ for the complex.

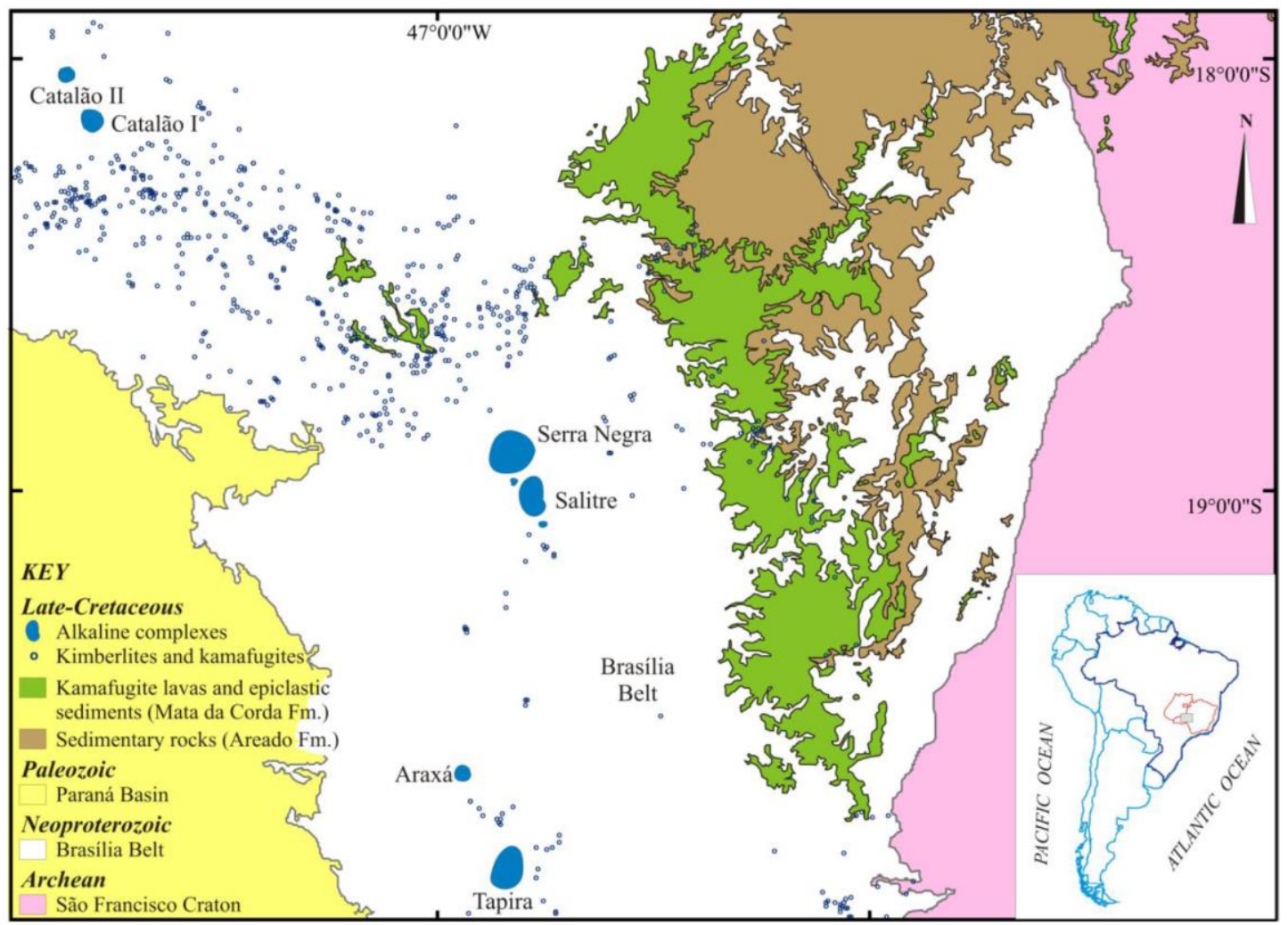

Figure 2.3: Geological map of the Alto Paraíba Igneous Province. From Barbosa (2009) after Oliveira et al (2004)

Many authors described silicate rocks (ranging from ultramafic cumulates to syenitic rocks), carbonatites and phoscorites (Haggerty and Mariano, 1983; Mariano and Marchetto, 1991; Morbidelli et al., 1997). Mafic and intermediate feldspar- or feldspathoid-bearing rocks are missing at Salitre, similarly to all other APIP plutonic complexes (e.g., Brod et al., 2004).

Morbidelli et al. (1997) indicated based on outcrops and fresh drill cores that Salitre I and II are dominated by silicate rocks, mainly clinopyroxenites in Salitre I and perovskitedunites in Salitre II. Barbosa et al. (2012), however, state that the majority of described rocks presents clinopyroxene abundance lower than 50\%, with modal apatite, perovskite, magnetite and phlogopite sums often exceeding that of olivine and clinopyroxene. Therefore, the classification of Salitre rocks in a simplified framework (i.e. considering only olivine and clinopyroxene) does not contemplate their real composition, facies variation and alkaline character of the complex. Both intrusions hold carbonatites that, along with the silicate 
cumulates, may grade to phoscoritic rocks. Available data on Salitre III are still scarce, but preliminary information suggests that it is essentially composed of bebedourites locally associated with phoscorite-series rocks (Barbosa et al., 2012).

Barbosa et al. (2009; 2012), analyzed recent drilling, petrographic, geochemical and geophysical data, as well as the available literature information (Brod et al., 2004; Morbidelli et al., 1997) and proposed an interpretative geological map of Salitre I (Figure 2.4), composed of at least three major intrusive systems: bebedourite, phoscorite and carbonatite.

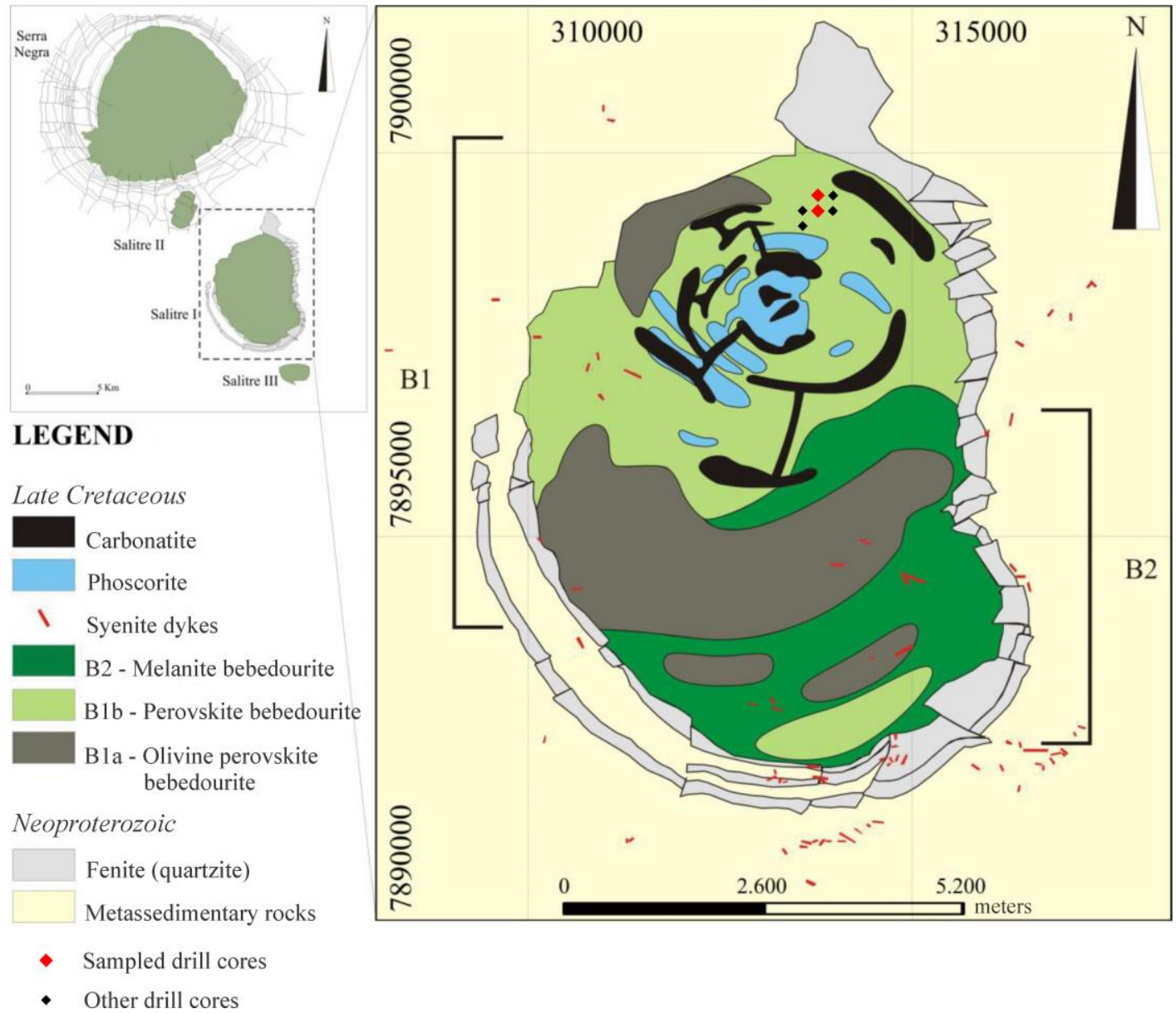

Figure 2.4: Interpretative geological sketch of the Salitre complex (Barbosa, 2009) and the location of the drill cores examined and sampled during this work.

The mineralogy of the Ca-Ti bearing phases separates the bebedourite system in two types: perovskite bebedourites (B1) and Ti-garnet/titanite bebedourites (B2). Perovskite bebedourites are further subdivided into olivine bearing (B1a, corresponding to the perovskite-rich dunites and pyroxenites of Morbidelli et al., 1997) and olivine free (B1b). Modal variations are frequent, including facies rich in olivine, phlogopite, perovskite, and apatite. Barbosa et al. (2012) also suggests that B1a and B1b are part of a cumulate pile. 
Olivine free bebedourites are more homogeneous and abundant at the southern part of the complex. They are further subdivided into B2a (perovskite+titanite+Ti-garnet), B2b (Tigarnet-only), and B2c (titanite only and/or titanite+Ti-garnet). This sequence points to a progressive increase in $\mathrm{SiO}_{2}$ activity. $\mathrm{B} 2$ bebedourites also occur as dykes within $\mathrm{B} 1$ rocks, being interpreted as intrusive in that unit. Isotopic data ( $\mathrm{Sr}$ and $\mathrm{Nd}$ ) indicates that the bebedourite parental magmas originated in a metasomatized sub continental lithospheric mantle similar to other complexes of the APIP.

The phoscorite-series rocks intrude the central part of the B1 unit. Modal variations of olivine, apatite and magnetite are observed and characterize the phoscorite series, which includes phoscorite and rare apatitite, nelsonite and magnetitite. Barbosa et al. (2012) classify the phoscorites in two types: P1, with essential olivine, phlogopite and apatite (magnetite and traces of perovskite as accessory minerals); and P2 with olivine, apatite and magnetite as essential phases, and carbonate-rich pockets (pyrochlore and rare phlogopite as accessory) and pyrochlore traces. Salitre phoscorites evolve from P1 to P2, and their Sr-Nd isotopes agree well with the isotopic composition of the rest of the APIP.

The carbonatite series rocks are associated with phoscorites as ring and radial intrusions in the B1 unit. They comprise calcite carbonatites and dolomite carbonatites with olivine, apatite, phlogopite and opaque minerals as accessories, and can be divided in to four main types (C1, C2, C3 and D4). C1 magnesiocarbonatites contain aluminous phlogopite, aggregates of irregular apatite and rare olivine. C2 magnesiocarbonatites are composed almost entirely of carbonate. C3 rocks vary from olivine calciocarbonatite and pyrochlore calciocarbonatite to nearly pure calciocarbonatite. Apatite-, magnetite- and pyrochlore-rich (nelsonitic) cumulates are rare and individualized as C3a type. D4 magnesiocarbonatites are late stage, and contain accessory apatite and high Ba grades, possibly associated with barium carbonates (witherite or norsethite). Rocks from the bebedourite series are frequently converted to metasomatic phlogopitite metasomatized by the carbonatite intrusions. Metasomatic transformation of perovskite into anatase is also observed.

Syenites (S1) occur mostly as dykes and at the top of the cumulate sequence (Morbidelli et al., 1997), suggesting that they are evolved end members of the bebedourite series. This interpretation correlates with the rare presence of K-feldspar in some evolved bebedourites from Tapira complex (Brod et al., 2005). 
Barbosa et al. (2012) propose that the Salitre rock suites are related to each other through a complex magmatic evolution involving multiple events of fractional crystallization and liquid immiscibility. A primitive phlogopite picrite magma, typical of APIP complexes, generates olivine- and perovskite-rich cumulates (B1a) by crystal fractionation. Residual magma produced by removal of olivine and perovskite has increased $\mathrm{P}_{2} \mathrm{O}_{5}$ and $\mathrm{CO}_{2}$ contents, eventually leading to the separation of a phoscorite liquid (P1). The remaining silicate liquid crystallized as olivine-free perovskite bebedourite (B1b). Due to the increasing amount of volatiles in the silicate magma, a second immiscibility event occurs, generating Ti-garnet bebedourites (B2) and magnesiocarbonatites (C1). The carbonatite liquid evolves to other magnesiocarbonatites (C2) P and Fe rich phoscorites (P2) and calciocarbonatites (C3). D4 magnesiocarbonatites are the result of $\mathrm{C} 2$ fractionation, while $\mathrm{C} 3$ carbonatites results from co-evolution development or a final differentiation product of P2 phoscorites. Nelsonitic cumulates are produced through apatite, magnetite and pyrochlore fractioning within C3 calciocarbonatite. Syenites are the final member of the silicate magmas, evolving by fractional crystallization from Ti-garnet bebedourite B2.

\subsection{Petrography of Salitre weathering profile}

A total of 36 samples from two drill holes were analyzed. The drill cores selected contained rocks from the entire igneous assemblage (bebedourites, foscorites and carbonatite dikes and veins) as well as significative levels of wethered material. The sampling encompasses the entire weathering profile, from fresh rock to the upper level of alloterite.

The samples vary from fine to coarse grained, greyish green to red, with different cohesion grades, depending on the level of weathering. All described samples are grouped in four weathering horizons: Fresh Rock (8 samples), Altered Rock (2), Isalteritic Saprolite (10) and Alloteritic Saprolite (16).

For this work, the fresh rocks at the bottom of the profile are assumed as the igneous suite from which overlying weathering products developed. However, both the inhomogeneity of the parent rock and the possibility of introduction of allochthonous material in the system limit direct comparison between fresh rock and weathered products. These aspects make it especially difficult to perform mass and elemental balance calculations. In order to minimize these effects, each weathering horizon is characterized 
separately and qualitative observations and comparisons are made only when evidence for the original material from which each product developed is available.

\subsubsection{Fresh Rock Horizon}

Fresh rock samples from the studied drillcores comprise carbonatites, olivine-bearing bebedourites and phoscorites with different degrees of carbonatite metasomatism. Barbosa et al. (2012) classify the olivine-bearing bebedourites where perovskite is the main $\mathrm{Ca}-\mathrm{Ti}$ phase as B1a type, and interpret them as products of crystal accumulation. B1a bebedourites are typically medium to coarse grained, green, with brown (phlogopite) or gray/black (magnetite/perovskite) portions; carbonate veins are typically fine to medium grained, white or gray. Olivine and perovskite are the main cumulus phases, occurring as subhedral to anhedral grains. Diopside, magnetite, phlogopite and apatite are intercumulus phases. Olivine is frequently serpentinized and magnetite is variably oxidized. Perovskite is well preserved and optically zoned, associated with magnetite and ilmenite, and often rimmed by magnetite (Figure 2.5a). No perovskite+Ti-garnet or perovskite+Ti-garnet+titanite association, characteristic of more evolved bebedourites (Barbosa et al, 2012) was observed. Phlogopite is brown-yellow, large (often centimetric), well crystallized and often zoned, with characteristic dark green-orange pleocroism, suggesting some degree of chloritization. Metasomatized olivine-bebedourites are composed of 5-20\% olivine/serpentine, 3-20\% perovskite (+/-anatase), 5-40\% phlogopite/tetraferriphlogopite, 0-9 \% diopside, 8-16\% magnetite, 4-30 \% carbonates, and 4-7 \% apatite.

The studied phoscorites are spatially associated to the olivine bebedourites, and carbonatite veins mark the contact between these two rock types. The phoscorite samples are a medium to coarse-grained brownish rock, with cumulus olivine and apatite, and intercumulus phlogopite and magnetite/ilmenite. This phoscorite can be classified as P1 (Barbosa, 2009) due to the low proportion of magnetite versus olivine+apatite and accessory perovskite. Olivine crystals display variable degrees of serpentinization. Apatite is anhedral, typically fractured and shows minor zoning under the electron microscope. Metasomatic carbonate veins are abundant. The modal composition of metasomatized phoscorites averages 12-26\% olivine/serpentine, $26 \%$ phlogopite/tetraferriphlogopite, 7-16\% diopside, 8-13\% magnetite and $12-20 \%$ carbonates.

Carbonatite veins of variable size $(>0.5 \mathrm{~cm}$ to $5 \mathrm{~cm}$ ) and dykes (up to $50 \mathrm{~cm}$ ) cut the olivine-bearing bebedourite and phoscorite. Calcite and dolomite are the main mineral 
phases, with minor apatite, magnetite and tetraferriphlogopite. Trace amounts of sulfides (chalcopyrite and pyrite), barite, other carbonates (especially strontianite, minor ancyllite), pyrochlore and monazite are also found. Accessory minerals are usually dispersed in the carbonate matrix, but can also be concentrated in layers, suggesting magmatic bedding.

The sampled carbonatite dyke and most of the studied carbonatite veins are modally variable, Ca-rich, with traces of pyrochlore, being classified as C3 by Barbosa (2009). Apatite may form thin cumulates in the central portions of the carbonate vein, often containing magnetite and pyrochlore. Thin intercumulus monazite lamellae are found associated with calcite (Figure $2.6 \mathrm{c}$ ). The modal composition of sampled C3 carbonatite is up to $85 \%$ calcite, $5 \%$ dolomite, $5 \%$ pyrite, $1 \%$ phlogopite/tetraferriphlogopite, and < 1\% pyrochlore. D4 magnesiocarbonatite veins are composed of 55\% calcite, $35 \%$ dolomite, up to $3 \%$ barite and minor strontianite and pyrochlore.

More evolved Mg-carbonatites, with intercumulus barite and monazite are frequently associated with metasomatized anatase and classified as D4-carbonatite by Barbosa (2009). Apatite associated with late stage D4 magnesiocarbonatite dykes may form aggregates of euhedral crystals up to $20 \mu$ in carbonatite cavities, frequently associated with dolomite and monazite. Bebedourites metasomatized by D4 carbonatite contains apatite crystals overgrown by banded apatite with characteristic high birefringence and high Sr and REE contents (Figure $2.6 \mathrm{a}$ and $\mathrm{b}$ ).

Carbonatite veins cutting olivine-bebedourites generate banded crystal aggregates of metasomatic phlogopite (Figure 2.5 b). Rims of dark-orange metasomatic tetraferriphlogopite are often observed on large crystals of Al-rich magmatic phlogopite. Perovskite may be converted to metasomatic anatase, forming a rim near the contact of the carbonate vein with the bebedourite. Under the electron microscope, metasomatic anatase shows a complex texture, with internal fragments of residual perovskite surrounded by anatase rims, interstitial calcite and monazite (Figure 2.6 e and f). Residual perovskite cores show dissolution contacts. Magnetite affected by metasomatism often displays dissolved rims of patches, replaced by carbonate. Ilmenite exsolution lamellae are frequently preserved within the partially replaced magnetite, maintaining the original crystal orientation (Figure $2.5 \mathrm{f})$. 

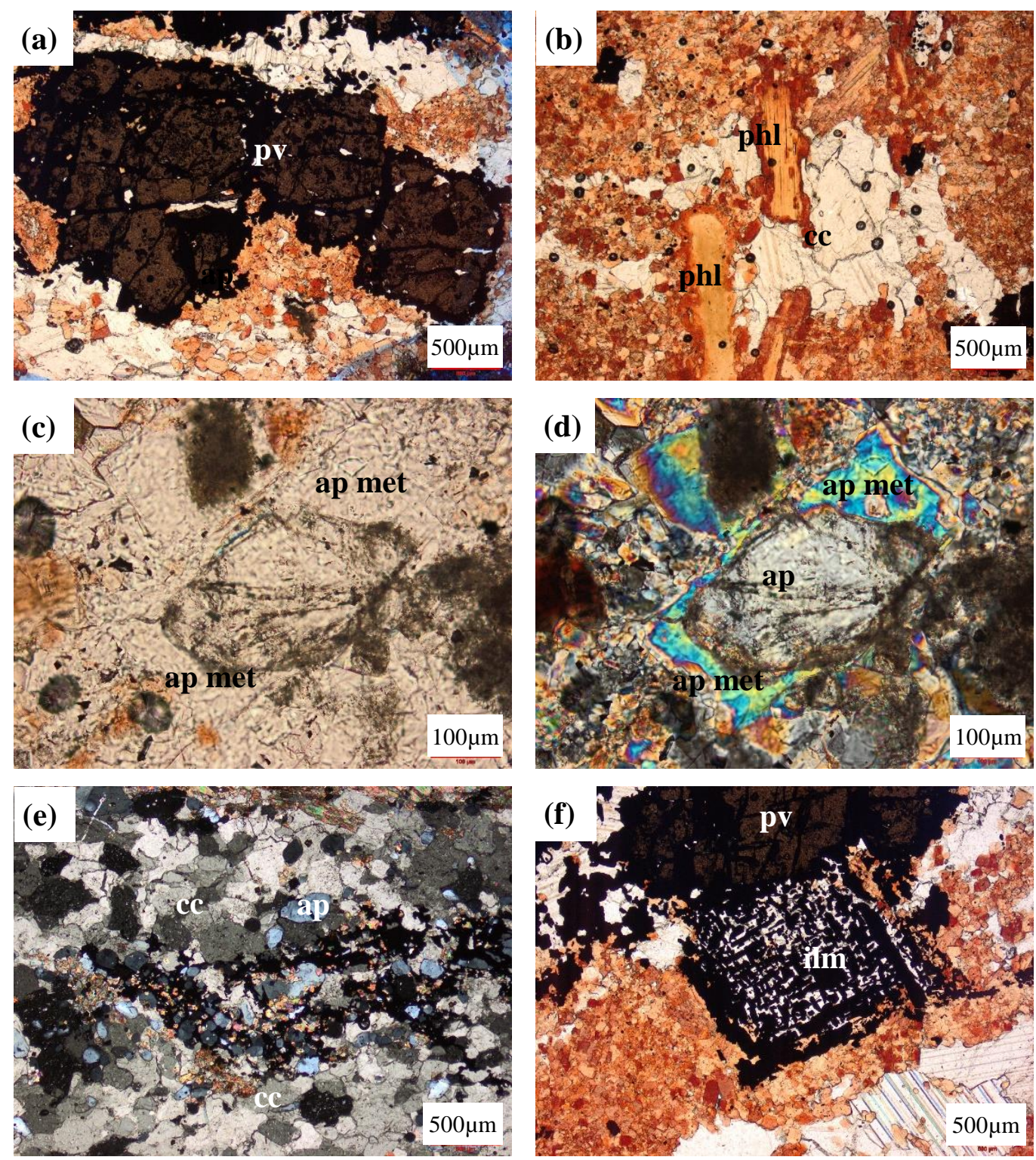

Figure 2.5: Photomicrographs of petrographic features of the fresh rock horizon. (a) Typical metasomatized bebedourite association of perovskite with magnetite rims, metasomatic carbonate and fine grained tetraferriphlogopite. (b) Large Al-rich phlogopite crystals showing dark red rims of tetraferriphlogopite alteration. (c) plane-polarized and (d) cross-polarized light image of apatite crystal with edges of high-Sr and high-REE apatite with high birrefringence. (e) cross-polarized image of carbonatite vein with round apatite and interstitial sulphide accumulation. (f) Dissolved magnetite with residual ilmenite trellis. $\mathrm{pv}=$ perovskite; $\mathrm{phl}=$ phlogopite; ap = apatite; met = metasomatic $; \mathrm{cc}=$ calcite $; \mathrm{ilm}=$ ilmenite . 

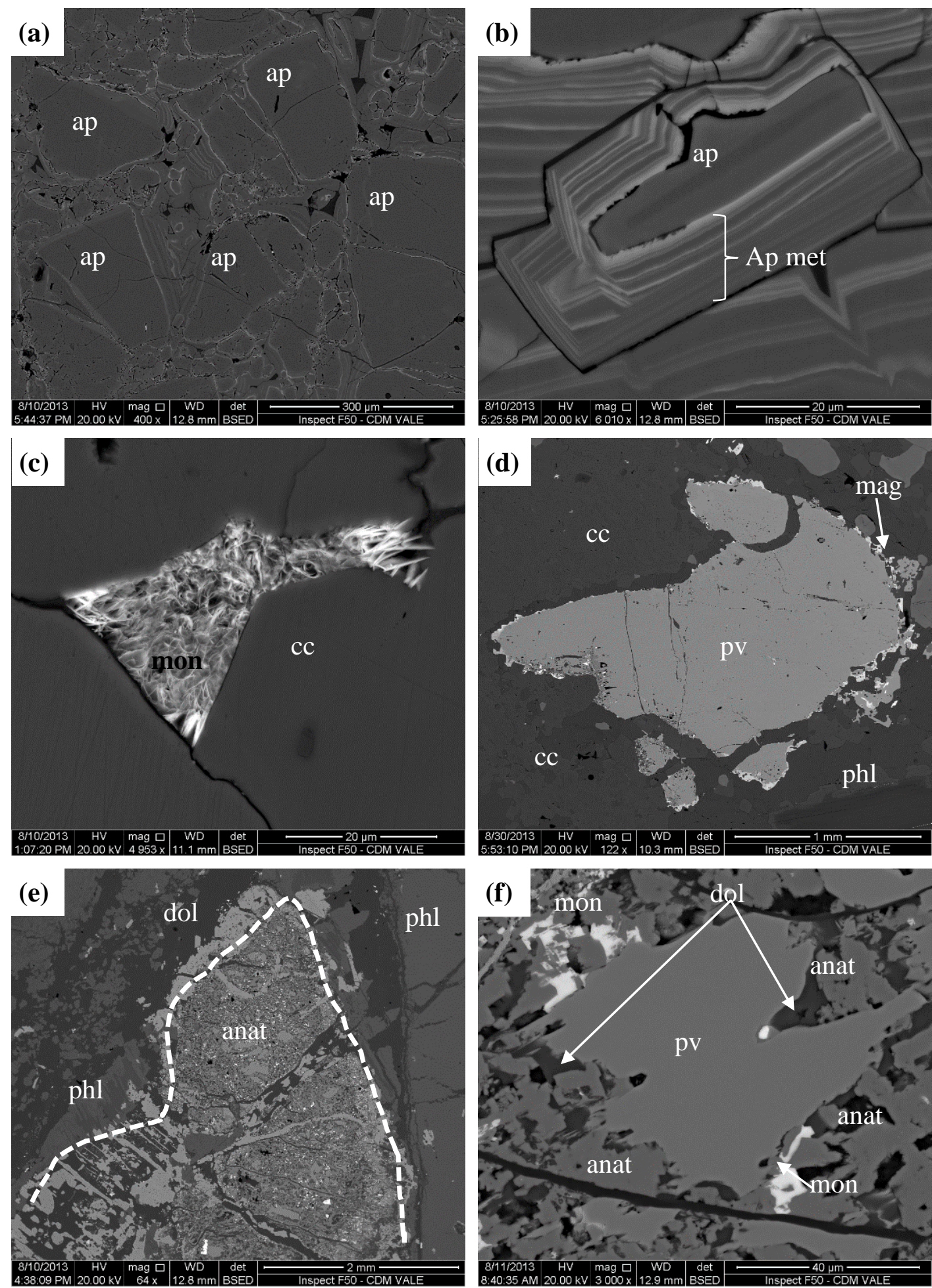

Figure 2.6: Back-scattered electron images showing selected petrographic features of the fresh rock horizon (a) apatite accumulation on phoscorite, with interstitial anhedral apatite rich in REE and Sr. (b) detail of (a). (c) intercumulus monazite lamellae in carbonatite vein. (d) Unaltered perovskite in metasomatized bebedourite intruded by D3 carbonatite. (e) Metasomatic anatase in bebedourite intruded by D4 carbonatite, showing complex texture. (f) Detail of (e): residual perovskite core, showing corrosion gulfs and metasomatic anatase, monazite and dolomite. pv = perovskite; phl = phlogopite; ap = apatite met $=$ metasomatic $; c c=$ calcite $; \mathrm{dol}=$ dolomite $;$ anat $=$ anatase $;$ mon = monazite; mag $=$ magnetite. 


\subsubsection{Altered Rock Horizon}

Two samples of metasomatized bebedourites from this domain were studied. The samples preserve the color and the cohesion of the fresh rock. The first observed weathering feature is the formation of films of iron-rich material along the suture planes of carbonate minerals (Figure 2.7). Further weathering develops a denticular aspect on carbonate edges, often related to the crystallographic orientation of the primary crystal (Delvigne, 1996). Complete carbonate weathering leaves empty spaces, or koilo alteromorphs (empty alteromorph) which might collapse or be filled by iron oxide/hydroxide alteroplasm. The presence of adjacent, more weathering-resistant minerals, such as phlogopite, perovskite, magnetite and apatite preserves the igneous rock texture.

Silicate minerals display limited chemical alteration within the altered rock horizon. Initially, phlogopite tends to develop K-depleted layers perpendicular to the $c$ axis (Figure 2.7), chemically similar to Mg-rich vermiculite, generating phylloporo-alteromorphs (sheetlike alteromorphs). Olivine and pyroxene crystals present fractures with denticular edges, filled with Mg-rich clays of the smectite group). Perovskite and magnetite crystals are well preserved in this horizon.

The bebedourites from this horizon roughly maintain the composition of the fresh rock: 5-20\% olivine/serpentine, 3-20\% perovskite (+/-anatase), 5-40\% phlogopite/TFphlogopite, 0-9 \% diopside, 8-16\% magnetite, 4-30\% carbonates and 4-7 \% apatite, with trace amounts of supergenic iron oxide/hydroxides and clays (mostly vermiculite and $\mathrm{Mg}$ rich smectites).
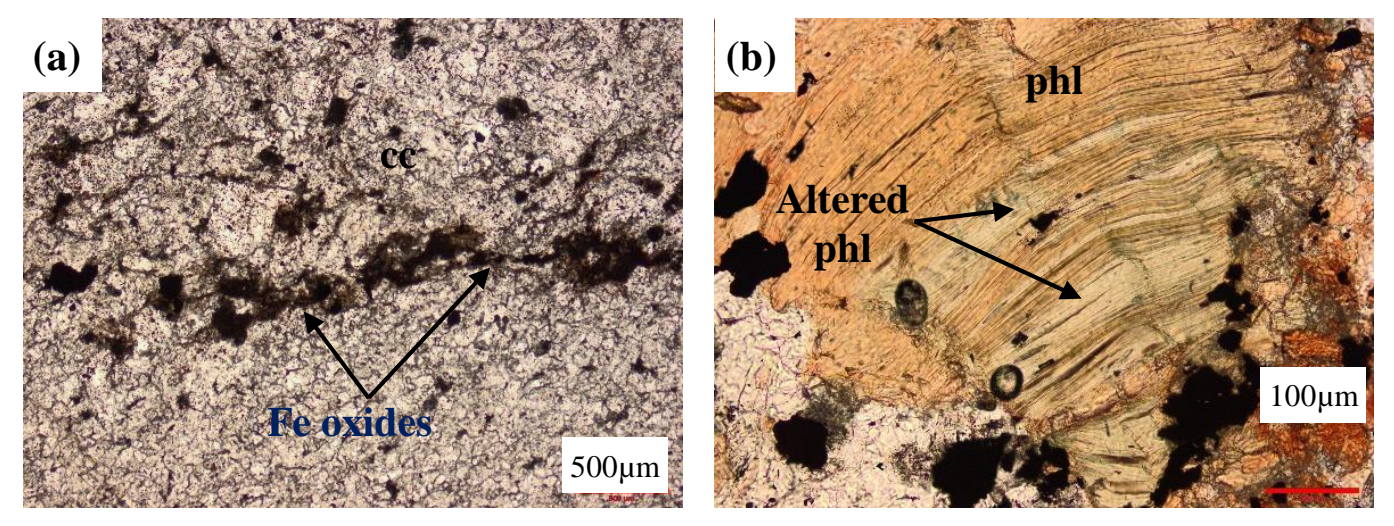

Figure 2.7 Photomicrographs of petrographic features of the altered rock horizon. (a) Iron oxide/hydroxide concretions interstitial to calcite crystals. (b) Light colored, K-depleted layers in phlogopite, with minor iron oxide/hydroxides along the cleavages. $\mathrm{Phl}=$ phlogopite. 


\subsubsection{Isalterite Horizon}

The sampled isalterite saprolite derives from weathering of metasomatized bebedourites and possibly phoscorites. The isalterite saprolite subdivisions based on hand sample and field observations from other APIP deposits are maintained as much as possible in this work to allow correlation (see Table 2-1 for nomenclature and references).

Carbonate are the first minerals to weather, forming koilo-alteromorphs promptly replaced by secondary products, mostly iron ore oxides/hydroxides. The degree of rock texture preservation is inversely proportional to the degree of metasomatic alteration of the protolith. Less metasomatized, pyroxene-rich bebedourites strongly preserve rock texture, even with initial chemical weathering of phlogopite and mafic minerals, whereas fine-grained metasomatic phlogopitite protoliths are less likely to have their texture preserved in the weathering profile. Residual accumulation of more weathering-resistant igneous apatite occurs throughout the isalterite horizon, which is the level where the phosphate ore is located. In some cases, secondary apatite precipitation as a cement or filling fractures and cavities is observed.

The Lower Micaceous Isalterite has an orange-brown mottled color, is medium to coarse grained and brittle. Large fragments $(>0,5 \mathrm{~cm})$ of phlogopite-like mica are well preserved, associated with centimetric banding of fine-grained mica. Some of the banding is reddish-brown, indicating the presence of dispersed iron oxides/hydroxides. The composition of Lower Isalterite samples derived from bebedourites is variable, containing 0-5\% phlogopite, 5-20\% perovskite; 35-50\% vermiculite/interstratified clay minerals, 0-20\% diopside, 9-10 \% magnetite, 6-8 \% iron oxides/hydroxides and 3-14 \% apatite. Phlogopite is gradually depleted in $\mathrm{K}$ and weathered to vermiculite meso-alteromorphs (Figure 2.8 a). Phlogopite-vermiculite sheets associated with iron oxides/hydroxides tend to be slightly oriented, suggesting collapse and compression due to volume reduction during carbonatite weathering. Some preserved fragments of pyroxene crystals surrounded by iron-impregnated clays display characteristic denticular limits (Figure 2.8 b). Perovskite begins to be replaced by microcrystalline anatase preferentially along fractures which develop into weathering gulfs, forming holo-alteromorphs. Small (<10um) and very rare acicular monazite concretions occur within and at the edges of this supergenic anatase. Supergenic apatite occurs as two different varieties (Figure $2.8 \mathrm{c} / \mathrm{d} / \mathrm{e}$ ): newly-formed apatite, growing from the walls of fractures in igneous apatite and rare, needle-shaped, radial apatite aggregates, 
possibly as cumulo-koilo alteromophs after dissolved carbonate minerals. Iron oxide/hydroxide aggregates are minor constituents.

The Upper Micaceous Isalterite is a fine grained, yellow-brown material where visible fragments of phlogopite-like mica are rare or absent. Composition is variable: 15-22\% vermiculite/interstratified clay minerals, 18-32 \% apatite, 28-33\% iron oxides/hydroxides, 5-6 \% perovskite/anatase, 8-9 \% magnetite, 1-5\% manganese oxides and 1-6\% monazite. This is a very apatite-rich horizon. Apatite fragments of apparent igneous origin often have fractures filled with secondary apatite. Small, often deformed fragments of vermiculite form a microscopic banding interstitial to fragments of apatite and magnetite/ilmenite (Figure 2.8 f). The vermiculite mass is porous and presents a variable degree of iron oxide/hydroxides impregnation, rendering the overall aspect of the thin sections more or less opaque. Perovskite alteration to anatase is advanced and the morphology of this alteration evolves from gulfs to channels inside perovskite crystals, with secondary anatase displaying concentric growth rings (Figure 2.9). Supergenic monazite forms acicular aggregates inside and on the walls of anatase, and as small veinlets within anatase masses. Acicular monazite aggregates often have "roots" embedded in anatase (Figure 2.9 e). In one sample, monazite also occurs as carbonate pseudomorphs supported by the vermiculite and iron oxide/hydroxide matrix. Hollandite forms accretion masses infilling residual pores.

Oxidized Isalterite is mostly composed of iron oxide/hydroxide alteromorphs supporting other residual minerals. Macroscopically visible vermiculite fragments are rare in this horizon. The Oxidized Isalterite contains 3-8 \% vermiculite/interstratified clay minerals, 18-36 \% apatite, 25-30\% iron oxides/hydroxides, 2-18\% perovskite/anatase, 8-9 \% magnetite, 1-5\% manganese oxides and 4-6\% monazite. Apatite is abundant, euhedral, elongated and fragmented. Fragments are often supported by iron oxide/hydroxide matrix but also form rare aggregates cemented by secondary apatite. Perovskite displays advanced alteration to anatase, with most crystals $>50 \%$ altered. Monazite pseudomorphs over carbonate are subordinate. 

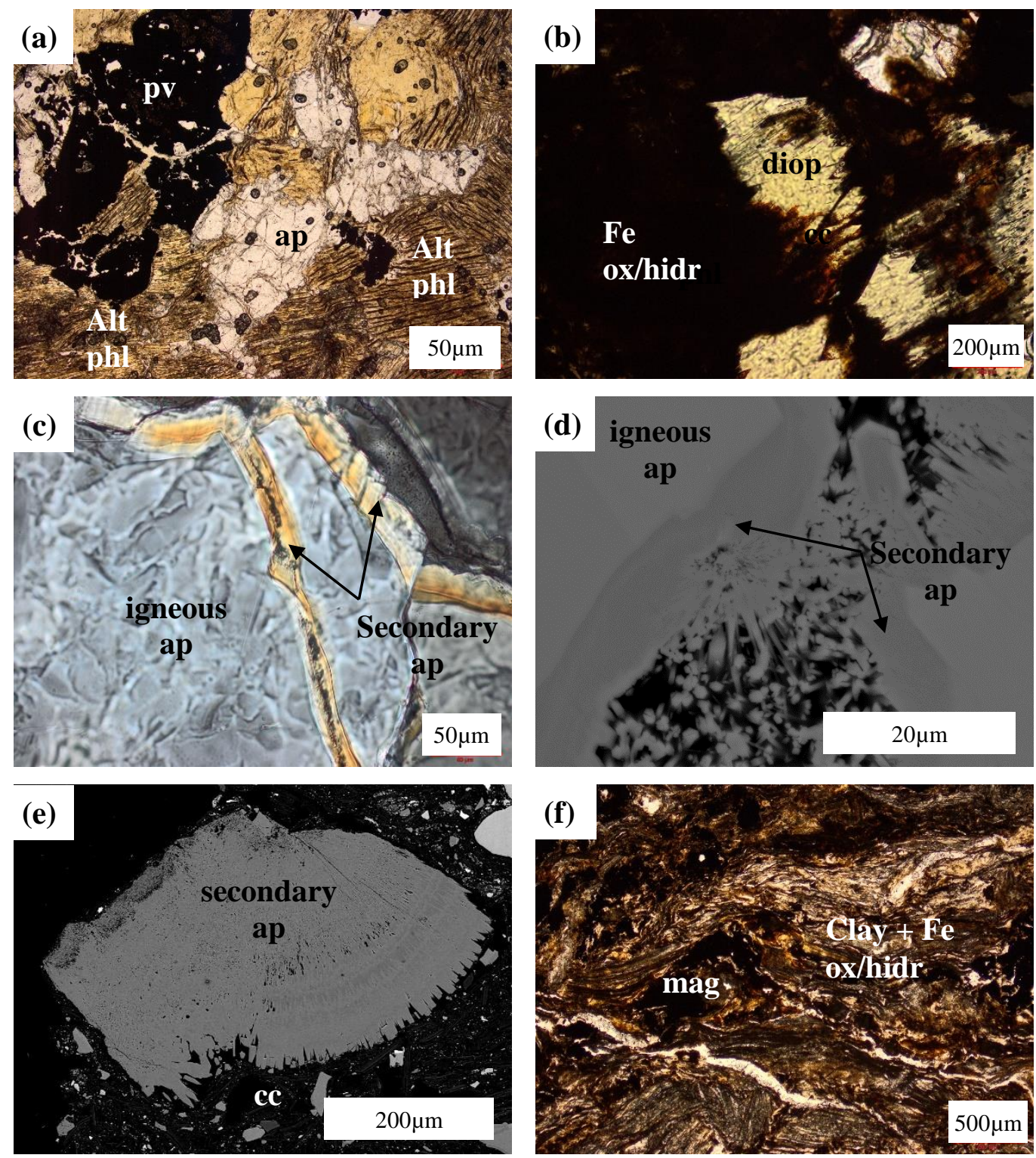

Figure 2.8: Photomicrographs (a/b/c/f) and back-scattered electron images $(\mathrm{d} / \mathrm{e})$ of petrographic features of the isalteritic horizon. (a) morphologically unchanged, K-depleted phlogopite altered to vermiculite; and (b) diopside weathering to iron oxide/hydroxide impregnated clays from lower micaceous isalterite $(\mathrm{c} / \mathrm{d}$ ) supergenic apatite (high birefringence) filling fractures in igneous apatite, from lower micaceous isalterite. (e) rare radial agglomerate of acicular secondary apatite, from lower micaceous isalterite. (f) deformed sheet-like clays with mild iron oxide/hydroxide impregnation from upper micaceous isalterite. $\mathrm{ap}=$ apatite $; \mathrm{phl}=$ phlogopite $; \mathrm{pv}=$ perovskite $;$ diop $=$ diopside $;$ Fe ox/hydrox $=$ iron oxide/hydroxides; mag $=$ magnetite . 
(a)
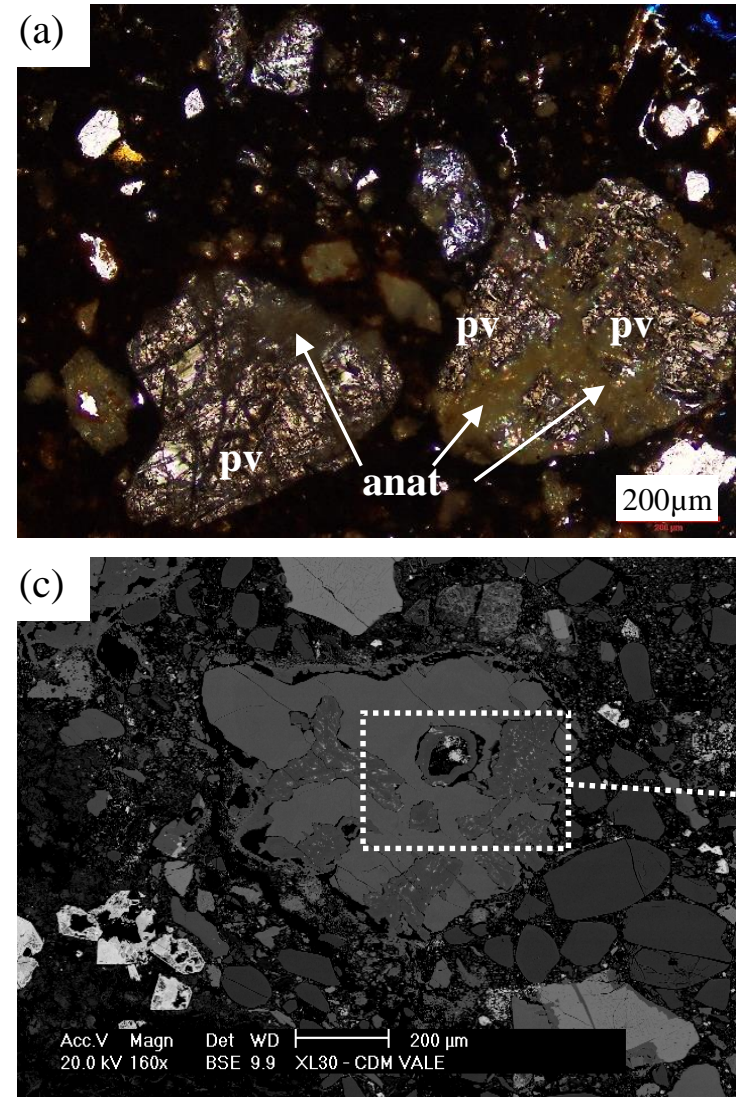

(e)

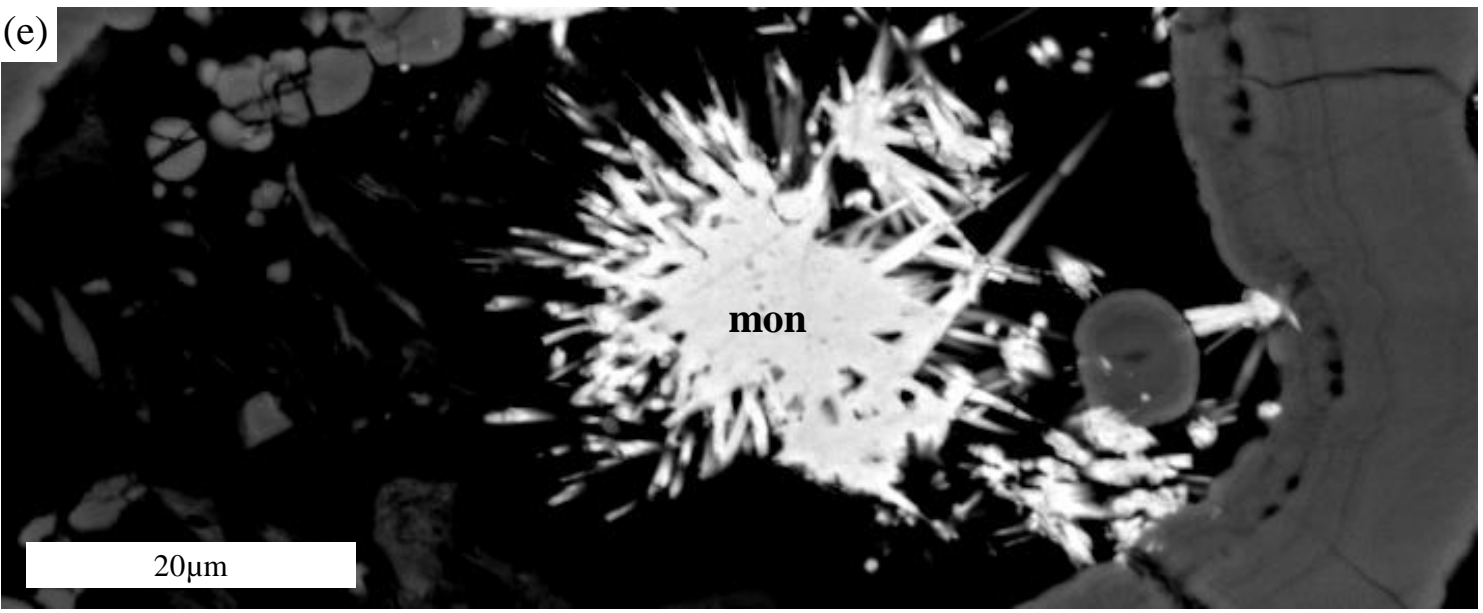

Figure 2.9: Photomicrographs $(\mathrm{a} / \mathrm{b})$ and back-scattered electron images $(\mathrm{c} / \mathrm{d} / \mathrm{e})$ of weathered perovskites from the upper micaceous isalterite. (a) Subhedral perovskite with corrosion tunnels impregnated with anatase. (b) acicular monazite crystals inside anatase "tunnel" developed inside perovskite. (c/d/e) weathered perovskite with corrosion gulfs and tunnels. Residual anatase contains traces of monazite (white). Detail of alteration channel with anatase accretionary walls and acicular monazite aggregate. $\mathrm{pv}=$ perovskite; anat $=$ anatase; mon = monazite. 


\subsubsection{Alloteritic Horizon}

Interstratified phyllosilicates are not stable in the upper part of the lateritic profile. They are replaced by kaolinite, gibbsite and iron oxide/hydroxides, eliminating all traces of the texture of the protolith. Perovskite is completely altered to anatase (holo-alteromorph) and apatite is no longer stable, being replaced by al-rich phosphates.

The Lower Alloterite is a fine grained, yellowish-red, extremely disaggregated material. Black manganese oxide may occur. Modal proportions are: 37-52 \% iron oxides/hydroxides, 9-33\% anatase, 0-15\% kaolinite, 4\%-12\% crandallite, 3-12 \% magnetite, 4-8\% manganese oxides and 2-8\% monazite. Perovskite is completely weathered to anatase, whose abundance peaks at this horizon. Final anatase alteromorphs are porous, microcrystalline, with "accretionary" textures and "rhythmic" layers deposited along fracture surfaces (Figure $2.11 \mathrm{a} / \mathrm{b}$ ). As in the isalterite, monazite (up to 5\%) is found both in association with anatase and as carbonate pseudomorphs. Apatite is no longer stable, being replaced by Al-rich phosphates. Crandallite forms porous botryoidal aggregates, occasionally massive, up to $0,5 \mathrm{~mm}$ in diameter (Figure 2.11). The association between crandallite and $\mathrm{Mn}$ oxides/hydroxides is frequent. Pyrochlore is rare and was observed only under the electron microscope. Quartz fragments were first observed in this level, and tend to accumulate in the base of the alloteritic profile (up to $18 \%$ accumulation). The fragments are variable in size $(10 \mu \mathrm{m}$ to $50 \mu \mathrm{m})$, often supported by an oxide/hydroxide matrix but also forming milimetric layered aggregate (Figure $2.11 \mathrm{c}$ ). As the weathering profile develops, the modal proportions of kaolinite increase (up to 15\%), as well as the proportion of manganese oxides (up to $8 \%$ ).

Upper Alloterite is also a fine grained, homogeneous yellowish-orange, completely disaggregated material. It is composed of 30-64\% kaolinite, 18-21\% iron oxides/hydroxides, 0-31\% gibbsite. Anatase, magnetite, perovskite, crandallite and quartz are minor constituents, supported by the argillaceous matrix. Closer to surface, modal proportions of gibbsite increase and those of kaolinite decrease. This level does not contain economic residual accumulation or precipitation of phosphate, titanium or REE minerals. 

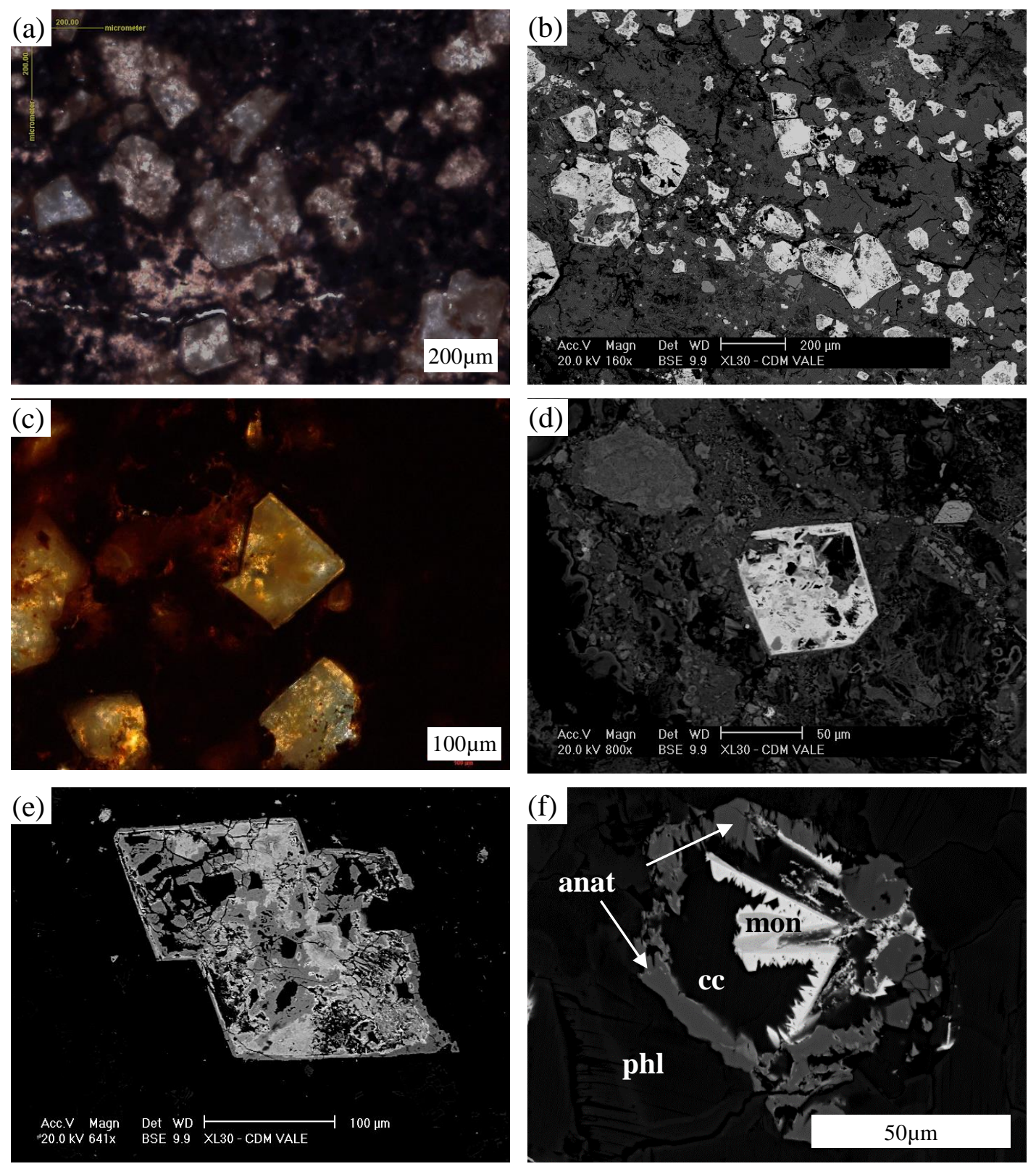

Figure 2.10: Photomicrographs $(\mathrm{a} / \mathrm{c})$ and Back-scattered electron images $(\mathrm{b} / \mathrm{d} / \mathrm{e} / \mathrm{f})$ of pseudomorphic monazites. $(\mathrm{a} / \mathrm{b})$ residual accumulation of pseudomorphic monazite in Oxidized Isalterite horizon, immersed in a porous and heterogenic matrix of iron (+-Si) oxide/hydroxide. (c/d/e) individual and geminated pseudomorphic monazite crystals from lower alloterite showing large cavities and complex textures. (f) calcite crystal partially replaced by monazite in fresh metasomatized bebedourite. Higher gray levels indicate higher REE and Th grades. anat = anatase; mon = monazite; phl = phlogopite; cc = calcite. 

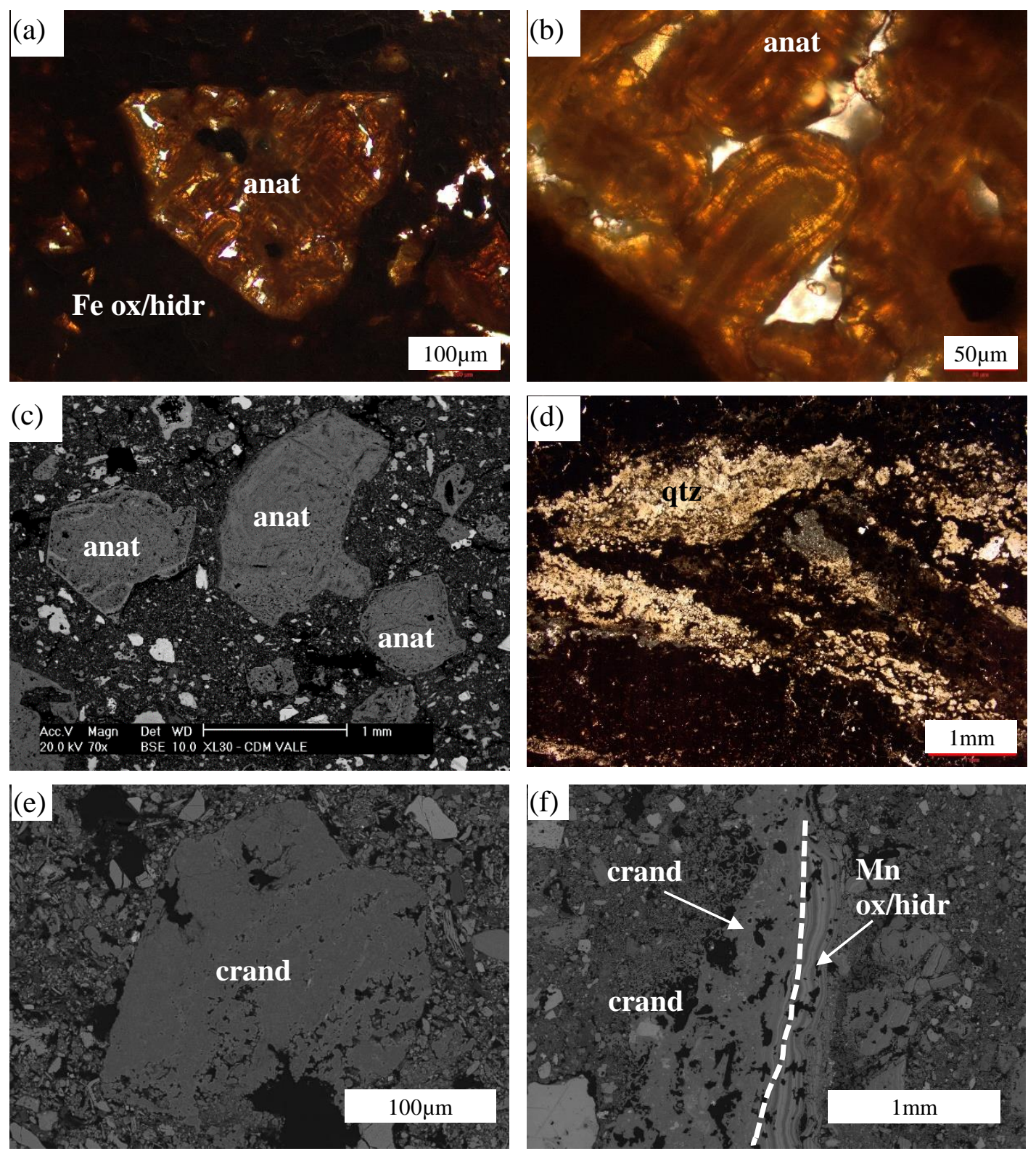

Figure 2.11: Photomicrographs $(\mathrm{a} / \mathrm{b} / \mathrm{d})$ and Back-scattered electron images (c/e/f) of petrographic features of the lower alloterite. $(\mathrm{a} / \mathrm{b} / \mathrm{c})$ perovskite completely weathered to anatase in a iron oxide/hydroxide matrix, a very common feature of the lower alloterite; (b) is a detail of accretionary texture of anatase.(d) Quartz banded accumulation at the base of the lower alloterite. (e) Massive microcrystalline crandallite aggregate. (f) Layered crandallite associated with Mn oxide/hydroxide agglomerate. Fe ox/hydrox = iron oxide/hydroxides; anat = anatase ; crand = crandallite; qtz $=$ quartz. 


\subsection{P, REE and Ti bearing mineralogy and mineral chemistry}

Mineral chemistry analyses were performed on 22 selected samples (6 samples analyzed by WDS and 17 by EDS). The main mineral phases present in the weathering profile were analyzed by WDS using a JEOL JXA-8230 electron microprobe at the University of Brasília. All analyses were carried out at $15 \mathrm{kV}$ and $20 \mathrm{nA}$. Standards for calibration were combinations of natural and synthetic minerals. Additional EDS analysis utilized a Inspect F50 scanning electron microscope at Vale Mineral Development Center in Belo Horizonte and a Jeol, JSM - 6610 scanning electron microscope at the University of Goiás. All EDS analysis at CDM were carried out at $20 \mathrm{kV}$ and at University of Goiás, at $15 \mathrm{kV}$, both with 60 seconds of acquisition time. In order to guarantee minimum EDS quality for mineral discrimination, all elemental analysis with calculated errors (in weight \%: +/- $1 \sigma$ ) larger than $12 \%$ (Miler and Mirtic, 2013) were disregarded and remaining elements normalized to $100 \%$.

In this work, we obtained 130 analyses of apatite, 97 of monazite, 28 of crandallite, 35 of perovskite and 96 of anatase. Additional 159 analyses were obtained to confirm and identify other oxides and silicates associated with the minerals targeted in this work.

\subsubsection{Phosphates}

\subsubsection{Apatite group}

Apatite $\left(\mathrm{Ca}_{10}\left(\mathrm{PO}_{4}\right)_{6}\left(\mathrm{OH}, \mathrm{F}, \mathrm{Cl}, \mathrm{CO}_{3}\right)_{2}\right)$ is the main phosphate bearer in the studied profile, and is the only phosphate ore mineral in worldwide magmatic phosphate deposits. It is a common constituent of bebedourites, phoscorites and carbonatites of alkaline-carbonatite complexes. Apatite is an early crystallizing phase in alkaline magmas and may persist up to the late stages of magmatic evolution (Hogarth, 1989). Primary phosphate mineralization in the APIP complexes may occur as apatite-rich bebedourite cumulates, as phoscorite dikes and as apatite rich cumulates derived from phoscorite and/or carbonatite magma (Brod et al 2004, Ribeiro 2008, Barbosa 2012, Ribeiro et al., 2014).

The ion occupying the monovalent site gives the name of the apatite species. Common substitutions in the that site involve $\mathrm{F}^{-}, \mathrm{OH}^{-}$and $\mathrm{Cl}^{-} . \mathrm{CO}_{3}{ }^{2-}$ substitution for some of the phosphate groups may also occur. The most frequent type of apatite found is fluorapatite 
$\left(\mathrm{Ca}_{10}\left(\mathrm{P}_{4}\right)_{6} \mathrm{~F}_{2}\right)$, but hydroxylapatite, carbonate-fluorapatite and carbonate-hydroxylapatite are also described in carbonatite complexes (Toledo et al., 2004)

Expected substitutes of $\mathrm{Ca}$ in the A site are mainly $\mathrm{Sr}, \mathrm{Ba}, \mathrm{REE}, \mathrm{U}$ and $\mathrm{Th}$, with Fe, $\mathrm{Mg}$ and $\mathrm{Na}$ occurring in smaller but variable concentrations (Hogarth, 1989). Kasputin (1980) points out the increase in $\mathrm{Ba}$ and $\mathrm{Sr}$ in apatite structure towards late stages of carbonatite evolution. Phosphate ideally occupies the $\mathrm{X}$ site, substituted more frequently by $\mathrm{CO}_{3}$ especially in apatite formed from a late-stage, carbonate-rich liquid during magma evolution (Hogarth, 1989). Si, Zr, As and S are feasible substitutes for $\mathrm{P}$ in the $\mathrm{X}$ site (Sommeraurer and Katz-Lehnert, 1985; Prins, 1973; Hogarth et al., 1985). During magmatic evolution, $\mathrm{SrO}, \mathrm{Na}_{2} \mathrm{O}, \mathrm{F}$ and $\mathrm{REE}_{2} \mathrm{O}_{3}$ contents might increase (Lee et al., 2004; Krasnova et al. 2004; Karchevsky \& Moutte, 2004).

During weathering, igneous apatite may have its composition changed and, in some cases, this mineral may be completely dissolved and precipitate as newly formed apatite and/or as complex phosphate minerals (Toledo, 2001). Apatite may show corrosion features and etching pits indicating incipient solution in the upper levels of the isalterite saprolite (Oliveira and Imbernon, 1998). Newly-formed apatite from weathered profiles over alkalinecarbonatitic complexes is chemically similar to the igneous apatite occurring in the corresponding fresh rock (Altschuler, 1973). Toledo et al., (2004a), indicate that this statement might be limited to observation scale and analytical techniques, since apatite can present ionic diffusion on solid state and removal of $\mathrm{F}, \mathrm{Ca}$ and $\mathrm{P}$ when attacked with citric acid (Montel, 1968; Gusev et al., 1976). Altschuler (1973) observed higher rates of Ca incongruent dissolution when compared to $\mathrm{P}$, diminishing $\mathrm{CaO} / \mathrm{P}_{2} \mathrm{O}_{5}$ in dissolution experiments over a temperature range of $25^{\circ} \mathrm{C}$ to $70^{\circ} \mathrm{C}$. Observed reactions from initial to weathered apatite include decrease in $\mathrm{Na}^{+}, \mathrm{Sr}^{2+}, \mathrm{SO}_{4}{ }^{2-}-\mathrm{e} \mathrm{CO}{ }_{3}{ }^{2-}$ concentrations (McArthur, 1985) and carbonate-fluorapatite transition to fluorapatite (Lucas and Flicoteaux, 1984), although there is still much controversy on whether this is due to anion removal from initial apatite or complete dissolution and precipitation of a new phase. Multiple generations of secondary apatite in alkaline rocks in Africa and Brazil show a progressive increase of $\mathrm{CO}_{2}$ content from 0 to about 8 wt \% (Girard et al., 1993; Piantone et al., 1995), and enrichment in F.

Fresh rock apatite from the Salitre I Complex presents variable chemistry, indicating different parent rocks, and strongly reflecting magma evolution processes (Barbosa et al., 
2012). For this work, textural/morphological features and mineral affiliation are used to separate apatite in three different groups: apatite associated with olivine-bearing bebedourites/phoscorites; apatite from late stage carbonatite veins/metasomatism; and supergenic apatite. Representative analyses of apatite from the fresh rock and the weathering profile over Salitre bebedourites are given in Table 2-2.

Igneous apatite from B1a and B1b bebedourites is often intercumulus, prismatic and commonly associated with perovskite and magnetite, as observed by Barbosa et al., (2012). Apatite with igneous composition found in weathered portions of the profile is interpreted as a residual, weathering-resistant phase. WDS analysis of igneous apatite show a narrow range of chemical variation, with average values close to the ideal fluorapatite composition: up to 4.4 wt \% F, 0.6 wt. \% $\mathrm{SiO}_{2}, 0.8$ wt. \% FeO, 0.42 wt. \% MgO, 0.82 wt. \% SrO, 0.32 wt. \% $\mathrm{BaO}, 0.19$ wt. $\% \mathrm{La}_{2} \mathrm{O}_{3}$, and 0.49 wt. $\% \mathrm{Ce}_{2} \mathrm{O}_{3} . \mathrm{Cl}$ is lower than 0.06 wt. \%, and below detection in most cases. $\mathrm{CaO} / \mathrm{P}_{2} \mathrm{O}_{5}$ averages 1,33 , slightly above the expected stoichiometric value of 1,31 (Figure 2.12a). Low Sr and REE values indicate that apatite from the B1 bebedourite sample is less evolved than that from other bebedourite types found in the complex (Barbosa et al., 2012, Figure 2.12).

Apatite from the more evolved carbonatite series yielded a wider compositional range, based on EDS analysis: up to 3.3 wt. \% F, 4.5 wt. \% NaO, 4.9 wt. \% SrO, 0.8 wt. \% $\mathrm{BaO}, 3.3$ wt. $\% \mathrm{La}_{2} \mathrm{O}_{3}$, and 6.6 wt. $\% \mathrm{Ce}_{2} \mathrm{O}_{3} . \mathrm{Cl}$ is lower than 0.06 wt. \%. $\mathrm{SiO}, \mathrm{FeO}$ and $\mathrm{MgO}$ values were bellow detection. Cumulate apatite in carbonatite veins and dykes is enriched in $\mathrm{Na}_{2} \mathrm{O}$ (up to 3.3 wt. \%, EDS) and $\mathrm{SrO}$ (up to 3.7 wt. \%, EDS) with no detectable $\mathrm{REE}_{2} \mathrm{O}_{3}$. Banded apatite overgrowths associated with D4 carbonatite intruding bebedourites is rich in $\mathrm{SrO}$ (up to 4.9 wt. \% EDS) and $\mathrm{REE}_{2} \mathrm{O}_{3}$ (up to 12 wt. \% EDS) with variable $\mathrm{Na}_{2} \mathrm{O}$ values (from below detection up to $3.8 \mathrm{wt}$ \% EDS). Under the electron microscope, REE- and Srrich layers cementing previous apatite can be easily identified (Figure 2.6a/b), and could indicate multiple dissolution/precipitation events during the metasomatic event/carbonatite implacement. Euhedral apatite aggregates associated with dolomite and monazite in carbonatite cavities are enriched in $\mathrm{Na}_{2} \mathrm{O}$ (above 3.5 wt. \% EDS) and have variable $\mathrm{REE}$ and Sr values. This variety is chemically similar to the apatite overgrowth in B1 bebedourites associated with D4 carbonatite, suggesting that the two types of apatite are related, although further analyses are required to confirm their association and evolution. 
Table 2-2. Representative apatite analysis from B1a Salitre bebedourites.

\begin{tabular}{|c|c|c|c|c|c|c|c|c|c|c|}
\hline Type & Ig. & Ig. & Ig. & Ig. & Metas. & Metas. & Metas. & Metas. & W & $\mathrm{W}$ \\
\hline & $\begin{array}{l}\text { Fresh } \\
\text { Rock }\end{array}$ & $\begin{array}{r}\text { Lower } \\
\text { Mic }\end{array}$ & $\begin{array}{r}\text { Lower } \\
\text { Mic }\end{array}$ & $\begin{array}{r}\text { Isalt. } \\
\text { Oxidado }\end{array}$ & $\begin{array}{l}\text { Fresh } \\
\text { Rock }\end{array}$ & $\begin{array}{l}\text { Fresh } \\
\text { Rock }\end{array}$ & $\begin{array}{l}\text { Fresh } \\
\text { Rock }\end{array}$ & $\begin{array}{l}\text { Fresh } \\
\text { Rock }\end{array}$ & $\begin{array}{r}\text { Lower } \\
\text {. }\end{array}$ & $\begin{array}{r}\text { Lower } \\
\text { Mic. Isalt }\end{array}$ \\
\hline $\begin{array}{l}\text { Depth } \\
\text { (m) }\end{array}$ & 166,50 & 157,2 & 130 & 127 & 157,2 & 106,5 & 106,5 & 106,5 & 157,2 & 145,2 \\
\hline Analisys & 1 & 2 & 3 & 4 & 5 & 6 & 7 & 8 & 9 & 10 \\
\hline Source & EDS & WDS & WDS & WDS & EDS & EDS & EDS & EDS & EDS & EDS \\
\hline $\mathrm{SiO}_{2}$ & n.d. & 0,05 & 0,08 & 0,48 & n.d. & n.d. & n.d. & n.d. & n.d. & n.d. \\
\hline $\mathrm{FeO}$ & n.d. & 0,04 & 0,07 & 0,14 & n.d. & n.d. & n.d. & n.d. & n.d. & n.d. \\
\hline $\mathrm{MgO}$ & n.d. & 0,01 & 0,02 & 0,04 & n.d. & 0,45 & n.d. & n.d. & 0,40 & n.d. \\
\hline $\mathrm{CaO}$ & 54,14 & 54,03 & 53,27 & 54,71 & 52,21 & 54,77 & 48,65 & 54,00 & 57,93 & 56,57 \\
\hline $\mathrm{BaO}$ & n.d. & 0,01 & 0,14 & n.d. & n.d. & n.d. & n.d. & n.d. & 0,76 & n.d. \\
\hline $\mathrm{SrO}$ & n.d. & 0,82 & 0,81 & 0,82 & 2,84 & 0,83 & 1,58 & 1,32 & n.d. & n.d. \\
\hline $\mathrm{Na}_{2} \mathrm{O}$ & n.d. & 0,12 & 0,23 & 0,12 & n.d. & 4,06 & 4,25 & 4,17 & n.d. & n.d. \\
\hline $\mathrm{P}_{2} \mathrm{O}_{5}$ & 42,82 & 42,20 & 39,72 & 40,35 & 43,12 & 38,13 & 36,04 & 38,27 & 36,67 & 39,73 \\
\hline $\mathrm{La}_{2} \mathrm{O}_{3}$ & n.d. & 0,10 & 0,19 & 0,06 & n.d. & n.d. & 2,86 & n.d. & n.d. & n.d. \\
\hline $\mathrm{Ce}_{2} \mathrm{O}_{3}$ & n.d. & 0,08 & 0,49 & 0,11 & n.d. & n.d. & 4,93 & n.d. & n.d. & n.d. \\
\hline $\mathrm{Pr}_{2} \mathrm{O}_{3}$ & n.d. & 0,01 & n.d. & 0,02 & n.d. & n.d. & n.d. & n.d. & n.d. & n.d. \\
\hline $\mathrm{Nd}_{2} \mathrm{O}_{3}$ & n.d. & n.d. & 0,19 & 0,02 & n.d. & n.d. & n.d. & n.d. & n.d. & n.d. \\
\hline $\mathrm{SO}_{3}$ & n.d. & n.d. & n.d. & n.d. & n.d. & n.d. & n.d. & n.d. & n.d. & n.d. \\
\hline $\mathrm{F}$ & 2,30 & 2,24 & 2,54 & 2,12 & n.d. & n.d. & n.d. & 0,93 & 4,68 & 3,60 \\
\hline $\mathrm{Cl}$ & n.d. & 0,02 & 0,02 & 0,02 & n.d. & n.d. & n.d. & n.d. & n.d. & n.d. \\
\hline $\mathrm{OH}$ & 0,75 & 0,75 & 0,55 & 0,78 & 1,82 & 1,76 & 1,68 & 1,33 & n.d. & 0,10 \\
\hline TOTAL & 100,01 & 100,86 & 98,53 & 99,94 & 99,99 & 100,00 & 100,00 & 100,01 & 99,99 & 100,00 \\
\hline $\mathrm{Si}$ & - & 0,008 & 0,013 & 0,081 & - & - & - & - & - & - \\
\hline $\mathrm{Fe} 2$ & - & 0,005 & 0,009 & 0,020 & - & - & - & - & - & - \\
\hline $\mathrm{Mg}$ & - & 0,002 & 0,005 & 0,009 & - & 0,113 & - & - & 0,100 & - \\
\hline $\mathrm{Ca}$ & 9,452 & 9,532 & 9,718 & 9,815 & 9,224 & 9,976 & 9,302 & 9,835 & 10,532 & 10,065 \\
\hline $\mathrm{Ba}$ & - & 0,001 & 0,009 & - & - & - & - & - & 0,051 & - \\
\hline $\mathrm{Sr}$ & - & 0,079 & 0,080 & 0,080 & 0,271 & 0,082 & 0,163 & 0,130 & - & - \\
\hline $\mathrm{Na}$ & - & 0,039 & 0,076 & 0,040 & - & 1,339 & 1,471 & 1,373 & - & - \\
\hline $\mathrm{P}$ & 5,908 & 5,883 & 5,726 & 5,720 & 6,020 & 5,487 & 5,445 & 5,508 & 5,268 & 5,586 \\
\hline $\mathrm{La}$ & - & 0,006 & 0,012 & 0,004 & - & - & 0,188 & - & - & - \\
\hline $\mathrm{Ce}$ & - & 0,005 & 0,030 & 0,006 & - & - & 0,322 & - & - & - \\
\hline $\operatorname{Pr}$ & - & 0,001 & - & 0,001 & - & - & - & - & - & - \\
\hline $\mathrm{Nd}$ & - & - & 0,012 & 0,001 & - & - & - & - & - & - \\
\hline S & - & - & - & - & - & - & - & - & - & - \\
\hline Cations & 15,360 & 15,585 & 15,711 & 15,785 & 15,516 & 16,997 & 16,892 & 16,847 & 15,951 & 15,651 \\
\hline
\end{tabular}

Rock types: 1-2: metasomatized olivine-rich bebedourite, 3 bebedourite, 4 phoscorite. 5-8: metasomatized bebedourite. 9-10: weathered bebedourite. Cations per formula unit calculated on the basis of 25 oxygen. $n . d .=$ not detected. ig $=$ igneous; Metas $=$ metasomatic; $\mathrm{W}=$ weathering product. 
Supergenic apatite occurs in two distinct habits: (a) filling fractures in igneous apatite and (b) as radial prismatic crystal aggregates (cumulo-koilo alteromophs), probably occupying leached carbonate voids. Supergenic apatite shows a homogeneous fluorapatite composition, based on EDS analysis. Values of $\mathrm{Na}_{2} \mathrm{O}, \mathrm{SrO}, \mathrm{BaO}$, and $\mathrm{REE}_{2} \mathrm{O}_{3}$ are bellow detection. $\mathrm{CaO} / \mathrm{P}_{2} \mathrm{O}_{5}$ ratio is up to 1.6 , the highest values reflecting the lowest values of $\mathrm{P}_{2} \mathrm{O}_{5}$. There is no identifiable chemical differences between the two types.

Relevant cation substitutions occur mostly on apatite from the carbonatite series. Substitutions of the britholite-type $\left(\mathrm{Ca}^{2+}+\mathrm{P}^{5+}=\mathrm{REE}^{3+}+\mathrm{Si}^{4+}\right)$ and belovite-type $\left(2 \mathrm{Ca}^{2+}=\right.$ $\mathrm{Na}^{+}+\mathrm{REE}^{3+}$ ) as described by Hogarth (1989) are observed. According to Barbosa et al. (2012) only minor britholite-type substitution is observed in igneous apatite from B1 rocks. In apatite from carbonatites, britholite type substitution occurs, with $\mathrm{Ca}^{2+}$ strongly replaced by $\mathrm{REE}^{3+}$, rendering a 1:1 negative correlation in Figure 2.12. $\mathrm{Ca}^{2+}$ substitution by $\mathrm{Na}^{+}$and $\mathrm{REE}^{3+}$ of the belovite type is evident, displaying the progression from bebedourite/phoscorite apatite to carbonatite apatite (Figure 2.12d). Sr-Ca substitution occurs in apatite from metasomatic origins, and is limited in igneous and supergenic apatite (Figure 2.12e). Metasomatic apatite also shows strong enrichment in REE associated with the $\mathrm{Sr}$ substitution. 

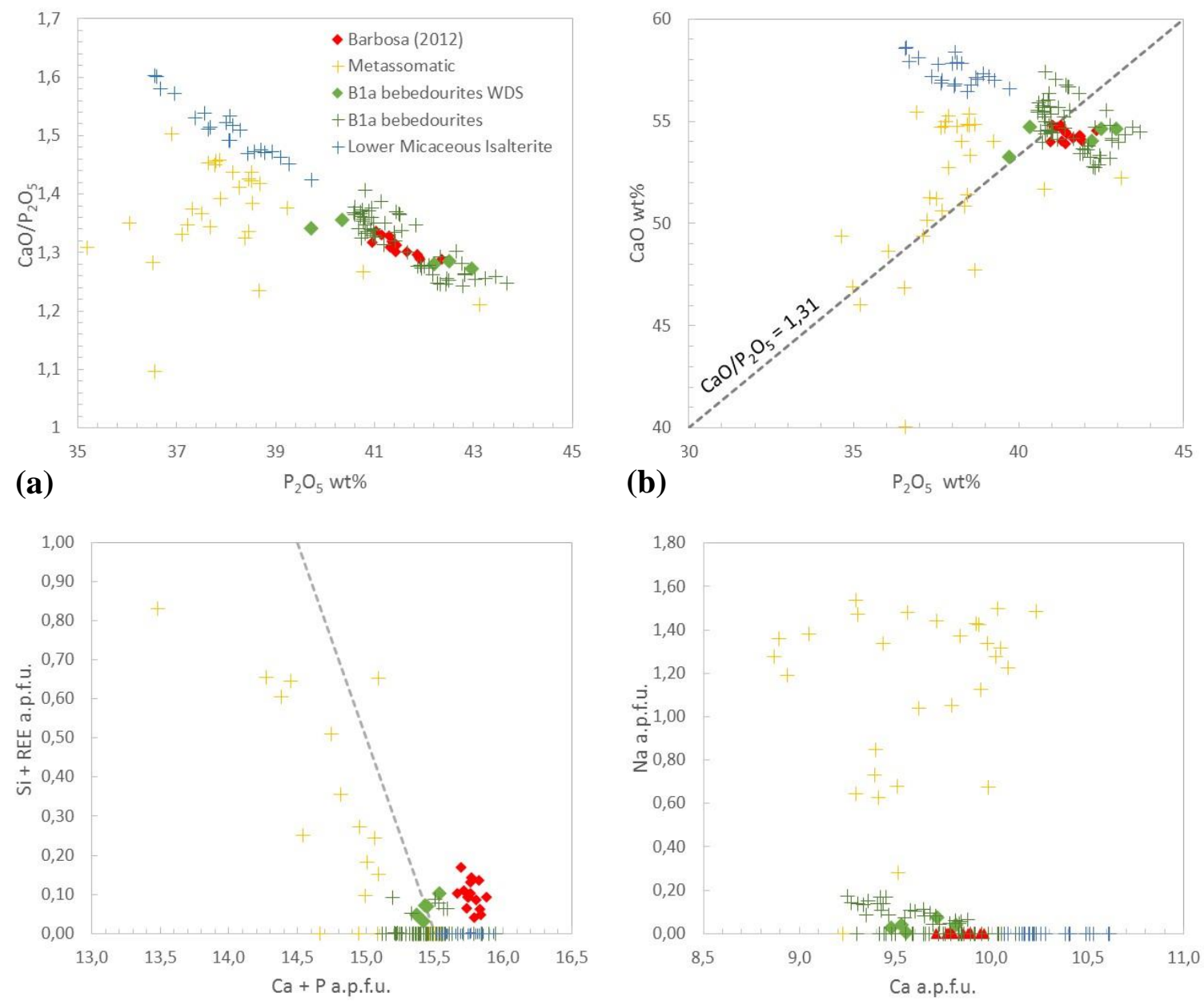

(c)

(d)
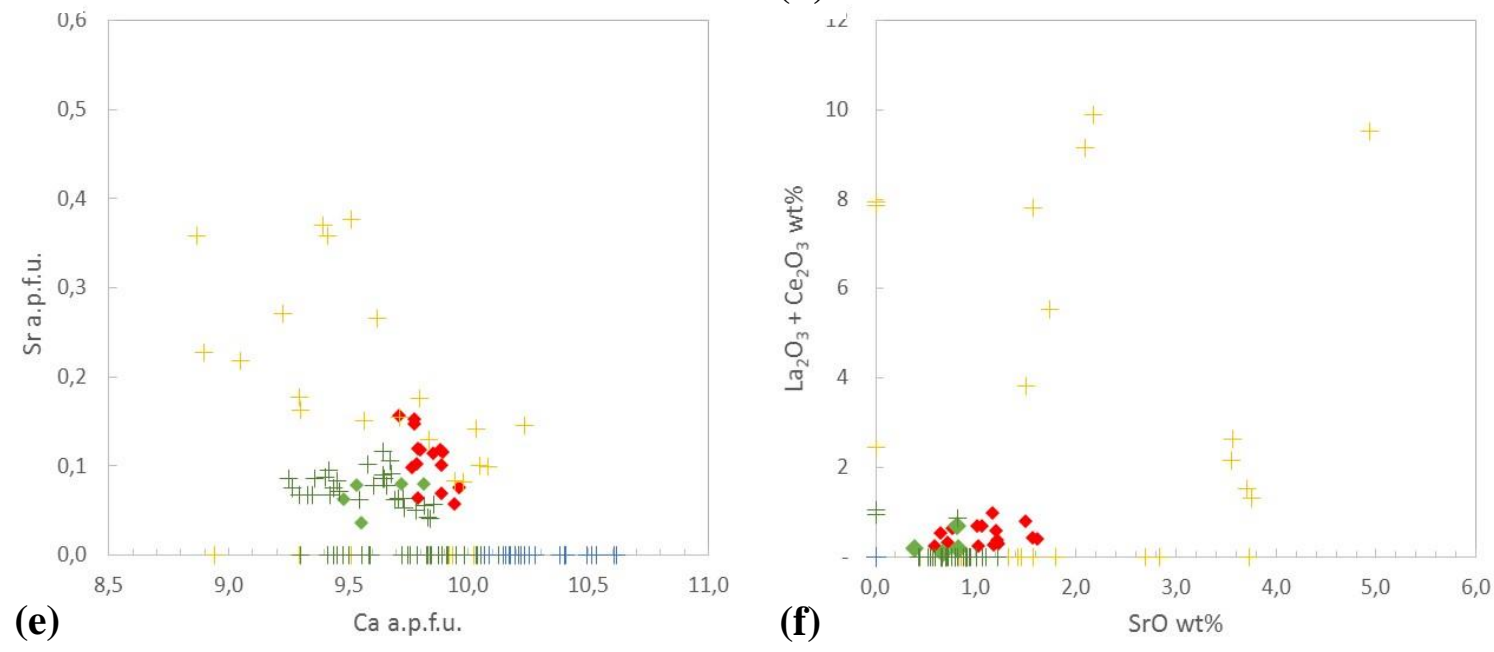

Figure 2.12: Substitutions and compositional trends for apatite in Salitre weathering profile. Crosses represent EDS analysis, and circle/diamond represent WDS analysis. a.p.f.u. $=$ atoms per formula unit. 


\subsubsection{Plumbogummite group}

The plumbogummite group is part of the alunite supergroup (Bayliss et al, 2010) and includes several members determined by the characteristic cations occupying the $\mathrm{X}$ position in a general formula $\mathrm{XAl}_{3}\left(\mathrm{PO}_{4}\right)_{2}(\mathrm{OH})_{5} \mathrm{H}_{2} \mathrm{O}$. The characteristic cations are $\mathrm{Pb}$ (plumbogummite), Ba (gorceixite), $\mathrm{Sr}$ (goyazite), $\mathrm{Ca}$ (crandallite) and $\mathrm{Ce}$ (florencite, with the specific formula $\left.\mathrm{CeAl}_{3}\left(\mathrm{PO}_{4}\right)_{2}(\mathrm{OH})_{6}\right)$. Extensive solid solutions exist between members of the group (Blanchard, 1972). Mordberg et al (2000) suggest that the distribution of REE in crandallite group minerals can be used to determine different weathering conditions. Crandallite from the Schugorsk deposit in Russia crystallized under strongly oxidizing conditions, and has negative $\mathrm{Ce}$ anomalies due to the loss of oxidized $\mathrm{Ce}^{4+}$ to other mineral phases.

The highest concentrations of crandallite group minerals are found in the Lower Alloterite Horizon of the weathering profile. Typical WDS analyses are displayed in Table 2-3. They present wide chemical variation: 1.6 to 5.5 wt. $\% \mathrm{CaO}, 1.3$ to 12.3 wt. \% $\mathrm{BaO}, 3.0$ to 5.8 wt. $\% \mathrm{SrO}, 1.1$ to 6.4 wt. $\% \mathrm{REE}_{2} \mathrm{O}_{3} . \mathrm{PbO}$ and $\mathrm{V}_{2} \mathrm{O}_{5}$ occur in trace amounts. The presence of $\mathrm{Ca}, \mathrm{Ba}, \mathrm{Sr}$ and $\mathrm{REE}$ in different proportions suggests that the minerals are a solid solution between crandallite, gorceixite and goyazite, with minor contents of REE (fluorencite). Substitution of $\mathrm{Fe}_{2} \mathrm{O}_{3}$ for $\mathrm{Al}_{2} \mathrm{O}_{3}$ is observed. $\mathrm{SiO}_{2}$ values increase with the weathering development (Figure 2.13b). Specimens closer to the top of the weathering profile display lower $\mathrm{Ca}$ values for the same $\mathrm{Sr}$ and $\mathrm{Ba}$ contents, suggesting an evolution towards gorceixite and goyazite (Figure 2.13b).

Monazite is the second most representative phosphate mineral in the metasomatized bebedourite weathering profile. It will be discussed in the next section, since it is the main bearer of Rare Earth Elements.

\subsubsection{Rare earth elements mineralogy and mineral chemistry}

Rare earth elements are dispersed as trace elements in oxides, phosphates and carbonates, and as major elements in some phosphates and carbonates. Rare earth traces in apatite and perovskite were discussed in the corresponding specific sections of this work. 
Table 2-3. Representative crandallite analysis from B1a Salitre bebedourites.

\begin{tabular}{|c|c|c|c|c|c|c|c|c|}
\hline \multirow[b]{2}{*}{ Depth. (m) } & \multicolumn{8}{|c|}{ Lower Alloterite } \\
\hline & 88,80 & 88,80 & 88,80 & 88,80 & 80,25 & 80,25 & 80,25 & 80,25 \\
\hline Analysis & 1 & 2 & 4 & 5 & 7 & 9 & 11 & 12 \\
\hline $\mathrm{SiO}_{2}$ & 0,41 & n.d. & 0,80 & 1,04 & 5,71 & 0,16 & 3,57 & 2,07 \\
\hline $\mathrm{TiO}_{2}$ & 3,08 & 0,82 & 1,32 & n.d. & 1,78 & 0,32 & 1,29 & 1,31 \\
\hline $\mathrm{ZrO}_{2}$ & 0,02 & 0,17 & n.d. & 0,01 & 0,23 & n.d. & 0,29 & 0,06 \\
\hline $\mathrm{ThO}_{2}$ & 0,03 & n.d. & n.d. & n.d. & n.d. & 0,07 & 0,06 & n.d. \\
\hline $\mathrm{Al}_{2} \mathrm{O}_{3}$ & 33,14 & 32,49 & 31,70 & 31,42 & 30,66 & 32,07 & 31,26 & 30,02 \\
\hline $\mathrm{Fe}_{2} \mathrm{O}_{3}$ & 2,16 & 2,02 & 2,77 & 3,28 & 12,36 & 6,53 & 11,29 & 12,18 \\
\hline $\mathrm{MnO}$ & n.d. & n.d. & n.d. & 0,03 & 0,11 & 0,14 & n.d. & 0,14 \\
\hline $\mathrm{MgO}$ & 0,02 & n.d. & n.d. & 0,02 & n.d. & 0,03 & n.d. & 0,04 \\
\hline $\mathrm{CaO}$ & 5,16 & 5,51 & 4,02 & 4,46 & 2,59 & 2,89 & 2,61 & 2,46 \\
\hline $\mathrm{BaO}$ & 2,96 & 2,64 & 3,54 & 3,39 & 4,48 & 12,32 & 3,11 & 3,43 \\
\hline $\mathrm{SrO}$ & 5,81 & 5,48 & 5,63 & 5,45 & 3,55 & 3,15 & 5,46 & 4,90 \\
\hline $\mathrm{PbO}$ & 0,05 & 0,02 & n.d. & n.d. & n.d. & n.d. & 0,03 & 0,09 \\
\hline $\mathrm{Na}_{2} \mathrm{O}$ & n.d. & n.d. & 0,01 & 0,05 & 0,02 & 0,08 & 0,01 & 0,03 \\
\hline $\mathrm{K}_{2} \mathrm{O}$ & 0,01 & 0,05 & 0,01 & 0,05 & 0,04 & 0,02 & 0,05 & 0,06 \\
\hline $\mathrm{P}_{2} \mathrm{O}_{5}$ & 29,34 & 30,55 & 31,16 & 29,20 & 21,58 & 25,46 & 23,14 & 24,66 \\
\hline $\mathrm{Nb}_{2} \mathrm{O}_{5}$ & 0,07 & 0,04 & 0,08 & n.d. & 0,15 & n.d. & 0,14 & 0,16 \\
\hline $\mathrm{Ta}_{2} \mathrm{O}_{5}$ & n.d. & n.d. & n.d. & n.d. & n.d. & n.d. & n.d. & n.d. \\
\hline $\mathrm{La}_{2} \mathrm{O}_{3}$ & 0,83 & 1,20 & 1,01 & 1,07 & 0,86 & 0,36 & 0,95 & 0,97 \\
\hline $\mathrm{Ce}_{2} \mathrm{O}_{3}$ & 0,81 & 0,65 & 1,80 & 2,00 & 0,74 & 0,69 & 1,17 & 1,26 \\
\hline $\mathrm{Pr}_{2} \mathrm{O}_{3}$ & 0,22 & 0,26 & 0,19 & 0,22 & 0,16 & 0,04 & 0,15 & 0,17 \\
\hline $\mathrm{Nd}_{2} \mathrm{O}_{3}$ & 0,45 & 0,57 & 0,89 & 0,87 & 0,39 & n.d. & 0,58 & 0,53 \\
\hline $\mathrm{F}$ & 0,54 & 0,81 & 0,70 & 0,72 & 0,67 & 1,08 & 0,98 & 0,88 \\
\hline $\mathrm{Cl}$ & 0,04 & 0,02 & 0,09 & 0,05 & 0,02 & 0,01 & 0,05 & 0,08 \\
\hline $\mathrm{H}_{2} \mathrm{O}$ & 13,82 & 13,48 & 13,77 & 13,25 & 13,40 & 12,59 & 13,21 & 13,12 \\
\hline TOTAL & 99,01 & 96,89 & 99,85 & 96,84 & 99,49 & 98,04 & 99,58 & 98,83 \\
\hline $\mathrm{ETR}_{2} \mathrm{O}_{3}$ & 2,35 & 2,79 & 4,18 & 4,43 & 2,15 & 1,12 & 3,02 & 3,13 \\
\hline $\mathrm{O}=\mathrm{F}, \mathrm{Cl}$ & 0,24 & 0,35 & 0,31 & 0,31 & 0,29 & 0,46 & 0,43 & 0,39 \\
\hline Total & 98,77 & 96,54 & 99,54 & 96,52 & 99,21 & 97,59 & 99,15 & 98,45 \\
\hline $\mathrm{Si}$ & 0,060 & 0,001 & 0,119 & 0,160 & 0,873 & 0,026 & 0,547 & 0,321 \\
\hline $\mathrm{Ti}$ & 0,346 & 0,093 & 0,147 & - & 0,204 & 0,039 & 0,149 & 0,152 \\
\hline $\mathrm{Zr}$ & 0,002 & 0,012 & - & 0,001 & 0,017 & - & 0,022 & 0,004 \\
\hline Th & 0,001 & - & - & - & - & 0,002 & 0,002 & - \\
\hline $\mathrm{Al}$ & 5,818 & 5,794 & 5,552 & 5,713 & 5,527 & 6,054 & 5,647 & 5,478 \\
\hline $\mathrm{Fe}^{3}$ & 0,243 & 0,230 & 0,310 & 0,381 & 1,423 & 0,787 & 1,303 & 1,419 \\
\hline $\mathrm{Mn}$ & - & - & - & 0,004 & 0,015 & 0,019 & - & 0,019 \\
\hline $\mathrm{Mg}$ & 0,003 & - & - & 0,003 & - & 0,006 & 0,001 & 0,008 \\
\hline $\mathrm{Ca}$ & 0,824 & 0,893 & 0,640 & 0,738 & 0,424 & 0,496 & 0,428 & 0,408 \\
\hline $\mathrm{Ba}$ & 0,173 & 0,157 & 0,206 & 0,205 & 0,269 & 0,773 & 0,187 & 0,208 \\
\hline $\mathrm{Sr}$ & 0,502 & 0,481 & 0,485 & 0,487 & 0,315 & 0,292 & 0,486 & 0,440 \\
\hline $\mathrm{Pb}$ & 0,002 & 0,001 & - & - & - & - & 0,001 & 0,004 \\
\hline $\mathrm{Na}$ & - & - & 0,002 & 0,014 & 0,007 & 0,024 & 0,004 & 0,010 \\
\hline K & 0,001 & 0,009 & 0,002 & 0,010 & 0,008 & 0,004 & 0,009 & 0,012 \\
\hline $\mathrm{P}$ & 3,700 & 3,913 & 3,920 & 3,814 & 2,795 & 3,452 & 3,003 & 3,232 \\
\hline $\mathrm{Nb}$ & 0,005 & 0,002 & 0,005 & - & 0,010 & - & 0,009 & 0,011 \\
\hline $\mathrm{Ta}$ & - & - & - & - & - & - & - & - \\
\hline $\mathrm{La}$ & 0,045 & 0,067 & 0,056 & 0,061 & 0,048 & 0,021 & 0,054 & 0,056 \\
\hline $\mathrm{Ce}$ & 0,044 & 0,036 & 0,098 & 0,113 & 0,042 & 0,040 & 0,065 & 0,072 \\
\hline $\operatorname{Pr}$ & 0,012 & 0,015 & 0,010 & 0,012 & 0,009 & 0,002 & 0,008 & 0,009 \\
\hline $\mathrm{Nd}$ & 0,024 & 0,031 & 0,047 & 0,048 & 0,021 & - & 0,032 & 0,029 \\
\hline Cations & 11,807 & 11,740 & 11,621 & 11,778 & 12,006 & 12,041 & 11,965 & 11,906 \\
\hline $\mathrm{F}$ & 0,256 & 0,388 & 0,327 & 0,349 & 0,325 & 0,546 & 0,476 & 0,428 \\
\hline $\mathrm{Cl}$ & 0,011 & 0,005 & 0,023 & 0,013 & 0,005 & 0,001 & 0,014 & 0,020 \\
\hline $\mathrm{OH}$ & 13,733 & 13,608 & 13,650 & 13,638 & 13,669 & 13,452 & 13,510 & 13,552 \\
\hline $\mathrm{H}_{2} \mathrm{O}$ & 13,821 & 13,484 & 13,772 & 13,253 & 13,398 & 12,593 & 13,214 & 13,121 \\
\hline
\end{tabular}

All analysis from lower alloterite bebedourites. Cations per formula unit calculated on the basis of 21 oxygen. n.d. = not detected. 


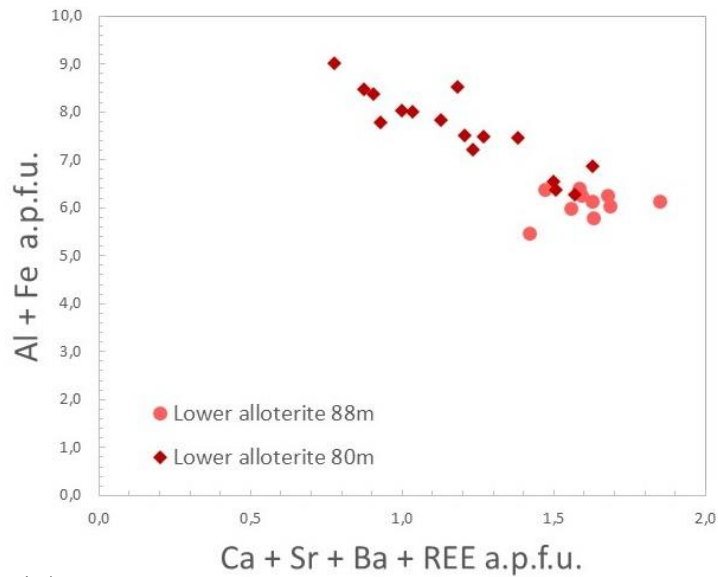

(a)

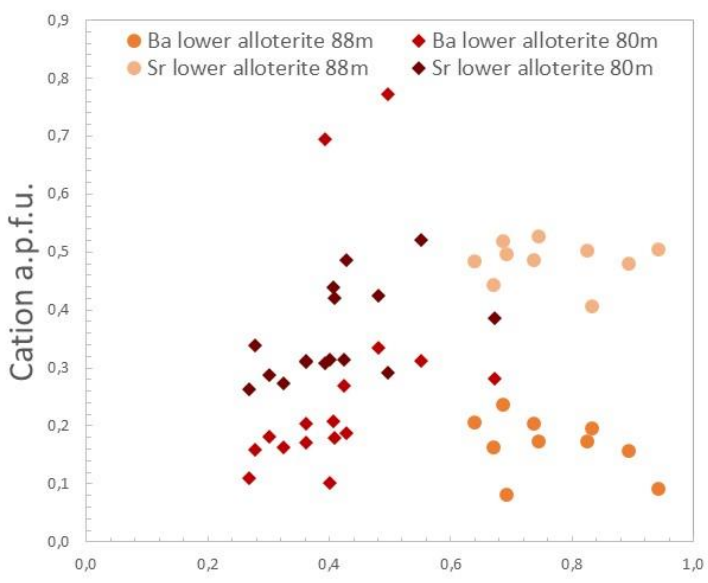

(c)

Ca a.p.f.u.

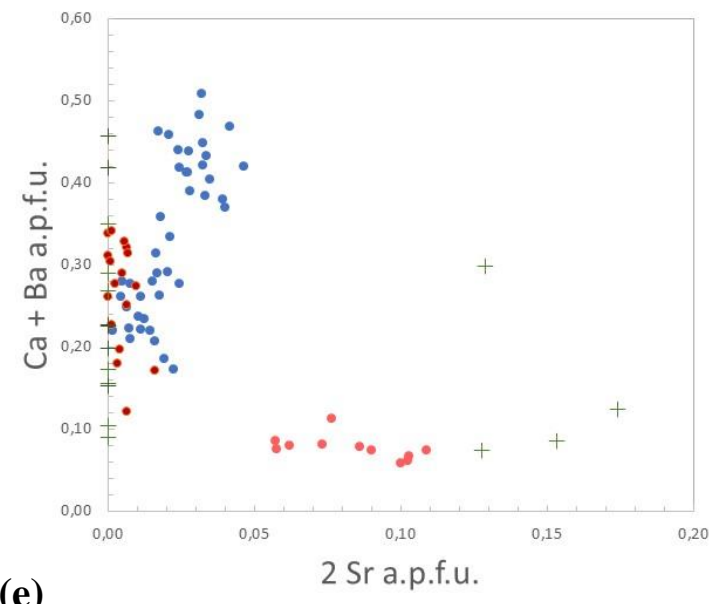

(e)

Figure 2.13: Substitutions and compositional trends for crandallite $(\mathrm{a} / \mathrm{b} / \mathrm{c})$ and monazite (d/e/f) in Salitre weathering profile. Legend for figures $\mathrm{a} / \mathrm{b}$ in figure $\mathrm{a}$. Legend for figures $\mathrm{d} / \mathrm{e} / \mathrm{f}$ in figure $\mathrm{d}$. Cross-cut symbols represent EDS analysis, and circles represent WDS analysis.

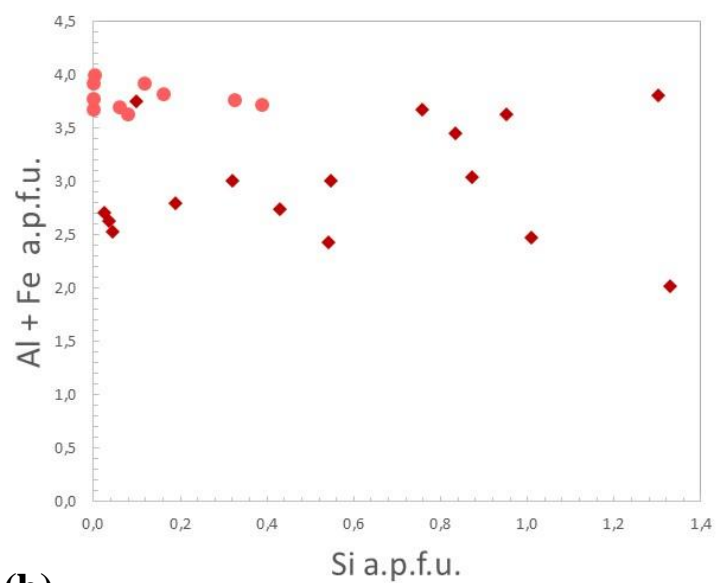

(b)
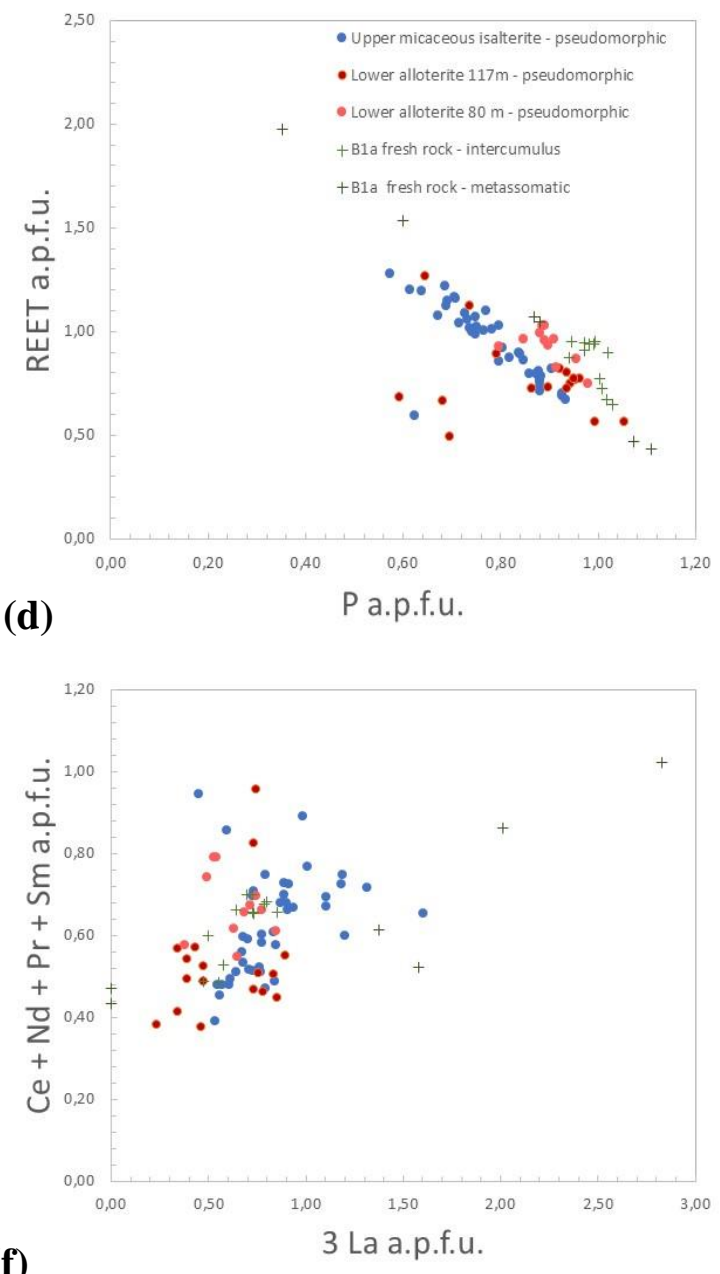

(f) 


\subsubsection{Monazite group}

Monazite is the main rare earth bearing mineral and occurs in variable proportions both in the fresh rock and in the lateritic profile. Along with bastnaesite, monazite is the principal ore carrier in worldwide REE economic deposits. It is commonly found in placer deposits, metamorphic products and weathering profiles over carbonatite complexes (Neumann and Lapido-Loureiro, 1993; Neumann, 1994; Toledo et al, 2002, 2004a; Toledo and Pereira, 2003). Structurally, monazite group minerals consist of the general formula $\mathrm{ABO}_{4}$ where the A site is occupied by $\mathrm{Bi}^{3+}, \mathrm{Ca}^{2+}, \mathrm{Ce}^{3+}, \mathrm{La}^{3+}, \mathrm{Nd}^{3+}, \mathrm{Th}^{4+}$ and $\mathrm{U}^{4+}$ and the $\mathrm{B}$ site is occupied by $\mathrm{As}^{5+}, \mathrm{P}^{5+}$ or $\mathrm{Si}^{4+}$ (Fleischer et al, 1990). In most monazites, the $\mathrm{B}$ site is dominated by $\mathrm{P}^{5+}$, with variable proportions of REE in the A site. The structure favors the incorporation of larger amounts of LREE than HREE, contrary to what is observed in xenotime (Ni et al., 1995).

In carbonatite complexes, REE concentrations in the primary igneous rocks are rare, but mineralization associated with metasomatic alteration is abundant (Wall and Mariano 1996). During acid weathering, in the absence of carbonate minerals, apatite is leached and secondary Al- and Fe-bearing phosphates are subsequently deposited (Lucas ad Flicoteaux, 1984). In the Catalão I complex of APIP, complex aggregates of sub-micrometric monazite crystals are observed as a replacement of leached carbonates, and also associated with quartz in silexite (Neumann and Lapido-Loureiro, 1993; Neumann, 1994; Toledo et al, 2004a). This monazite contains trace amounts of $\mathrm{Ca}, \mathrm{Sr}$ and $\mathrm{Ba}$ in the $\mathrm{A}$ site, and shows a moderate ion deficiency in the anionic site.

In the Salitre carbonatite complex, the unaltered igneous rocks contain monazite in small proportions (less than 1 modal \%), usually as a late-stage (intercumulus or hydrothermal) phase. This abundance is maintained in the Altered Rock Horizon. Within the Isalterite Horizon, monazite concentration increases, reaching a maximum at the Oxidized Isalterite, suggesting precipitation and/or residual accumulation.

Igneous/Hydrothermal monazite presents three main habits, lamellar, residual/anhedral and carbonate pseudomorphs. Lamelar monazite forms aggregates associated with dolomite, strontianite and barite, usually interstitial to calcite. This association suggests monazite crystallization from the REE-Ba-dolomite enriched D4-type carbonatite injections described by Barbosa, (2009). The residual/anhedral monazite results from hydrothermal alteration of perovskite to anatase. It forms small $(>10 \mu \mathrm{m})$ concretions 
inside skeletal hydrothermal anatase associated with calcite and residual fragments of perovskite. The highest rare earth grades found in the weathering profile (>3\% REO) are associated with presence of preserved igneous/hydrothermal pseudomorph-type monazite. Pseudomorph type monazite often preserves rhombohedral morphology and shows complex texture under the electronic microscope, indicating variation in REE, $\mathrm{Sr}$ and $\mathrm{Th}$ values (see Figure 2.10). In weathered horizons, it is found dispersed in a vermiculite iron oxide/hydroxide matrix. Some specimens show internal cavities filled with external matrix material, that could indicate partial dissolution of the monazite prior or during weathering. Nevertheless, pseudomorphic monazite seems stable during weathering, as observed by Toledo et al. (2004).

Supergenic monazite occurs in two main habbits: as very small (less than $20 \mu \mathrm{m}$ ) acicular crystals forming radial aggregates with high porosity, and as laminar to massive aggregates of variable sizes. Acicular crystals are associated with anatase or partially altered perovskite/anatase. Laminar aggregates are often found associated with the iron oxidehydroxide matrix.

Due to the nature of the described monazite, special care was taken during microprobe analysis. As described by Toledo et al. (2004), microcristaline, porous and more or less hydrated materials tend to yield analytical totals lower than $100 \%$. Analyses with total oxide sum lower than $80 \%$ were discarded. Available analyses from different types of monazite show that they are chemically similar, with $\mathrm{Ca}, \mathrm{Sr}$ and $\mathrm{Ba}$ in trace amounts and very low $\mathrm{Th}$ contents, as observed by Oliveira and Imbernon (1998) and Toledo et al., (2004) for Catalão I deposit. As expected, monazites from Salitre are enriched in LREE, with elements heavier than Dy not detected or close to the detection limits. REE values tend to decrease with the development of the weathering profile (Figure $2.13 \mathrm{~d}$ ). Th is often below 1 wt. \% with a maximum value of 4.27 wt. \% in pseudomorphic monazite in the Lower Alloterite. 
Table 2-4: Representative monazite analysis from B1a Salitre bebedourites.

\begin{tabular}{|c|c|c|c|c|c|c|c|c|c|c|c|c|}
\hline Type & Ps & Ps & Ps & Ps & Ps & Ps & Ps. & Met & Met & Met & Ps & Ps \\
\hline . & $\begin{array}{l}\text { Upper } \\
\text { Mic. } \\
\text { Isalt. }\end{array}$ & $\begin{array}{l}\text { Upper } \\
\text { Mic. } \\
\text { Isalt }\end{array}$ & $\begin{array}{l}\text { Upper } \\
\text { Mic. } \\
\text { Isalt }\end{array}$ & $\begin{array}{l}\text { Lower } \\
\text { Allot. }\end{array}$ & $\begin{array}{l}\text { Lower } \\
\text { Allot }\end{array}$ & $\begin{array}{l}\text { Lower } \\
\text { Allot }\end{array}$ & $\begin{array}{c}\text { Lower } \\
\text { Allot }\end{array}$ & $\begin{array}{l}\text { Fresh } \\
\text { Rock }\end{array}$ & $\begin{array}{l}\text { Upper } \\
\text { Mic. } \\
\text { Isalt }\end{array}$ & $\begin{array}{c}\text { Lower } \\
\text { Allot }\end{array}$ & $\begin{array}{c}\text { Lower } \\
\text { Allot }\end{array}$ & $\begin{array}{l}\text { Lower } \\
\text { Allot }\end{array}$ \\
\hline $\begin{array}{l}\text { Depth } \\
\text { (m) }\end{array}$ & 127,00 & 127,00 & 127,00 & 117,00 & 117,00 & 117,00 & 80,25 & 166,50 & 106,50 & 106,60 & 106,60 & 106,60 \\
\hline Analysis & 10 & 11 & 12 & 20 & 21 & 22 & 36 & 40 & 41 & 45 & 46 & 49 \\
\hline Source & WDS & WDS & WDS & WDS & WDS & WDS & WDS & EDS & EDS & EDS & EDS & EDS \\
\hline $\mathrm{SiO}_{2}$ & n.d. & 0,01 & 0,02 & n.d. & n.d. & n.d. & 0,08 & n.d. & n.d. & n.d. & n.d. & n.d. \\
\hline $\mathrm{ThO}_{2}$ & 1,56 & 0,99 & 0,34 & 0,04 & 0,05 & 0,10 & 4,27 & n.d. & n.d. & n.d. & n.d. & n.d. \\
\hline $\mathrm{Al}_{2} \mathrm{O}_{3}$ & 0,79 & 0,81 & 0,87 & 0,20 & 0,12 & 0,16 & 0,05 & n.d. & n.d. & n.d. & n.d. & n.d. \\
\hline $\mathrm{FeO}$ & 0,66 & 0,59 & 0,75 & 0,12 & 0,07 & 0,11 & 0,76 & n.d. & n.d. & n.d. & n.d. & n.d. \\
\hline $\mathrm{MnO}$ & n.d. & n.d. & n.d. & n.d. & n.d. & n.d. & 0,42 & n.d. & n.d. & n.d. & n.d. & n.d. \\
\hline $\mathrm{CaO}$ & 7,66 & 9,79 & 10,33 & 6,11 & 7,14 & 5,83 & 1,29 & 3,18 & 2,57 & 2,05 & 6,87 & 7,83 \\
\hline $\mathrm{BaO}$ & n.d. & n.d. & n.d. & n.d. & n.d. & n.d. & 0,48 & 2,71 & n.d. & n.d. & n.d. & n.d. \\
\hline $\mathrm{SrO}$ & 0,35 & 0,58 & 0,69 & n.d. & 0,13 & 0,13 & 1,63 & n.d. & n.d. & 3,41 & n.d. & 3,13 \\
\hline $\mathrm{PbO}$ & 0,12 & n.d. & n.d. & n.d. & n.d. & n.d. & n.d. & n.d. & n.d. & n.d. & n.d. & n.d. \\
\hline $\mathrm{P}_{2} \mathrm{O}_{5}$ & 21,65 & 20,35 & 26,93 & 25,56 & 25,88 & 27,96 & 22,22 & 28,86 & 32,11 & 29,65 & 32,58 & 33,84 \\
\hline $\mathrm{La}_{2} \mathrm{O}_{3}$ & 17,14 & 13,73 & 12,56 & 10,74 & 17,90 & 17,55 & 12,92 & 15,01 & 17,61 & 16,91 & 12,37 & 14,02 \\
\hline $\mathrm{Ce}_{2} \mathrm{O}_{3}$ & 25,05 & 22,81 & 20,24 & 22,86 & 13,50 & 11,22 & 23,97 & 33,72 & 36,78 & 33,06 & 30,70 & 28,90 \\
\hline $\mathrm{Pr}_{2} \mathrm{O}_{3}$ & 2,45 & 2,16 & 2,12 & 2,08 & 3,32 & 3,20 & 2,40 & n.d. & n.d. & 2,44 & 3,38 & n.d. \\
\hline $\mathrm{Nd}_{2} \mathrm{O}_{3}$ & 10,51 & 9,85 & 9,98 & 10,12 & 14,90 & 15,64 & 10,91 & 13,50 & 10,94 & 10,47 & 10,41 & 8,46 \\
\hline $\mathrm{Sm}_{2} \mathrm{O}_{3}$ & 0,35 & 0,47 & 0,32 & 1,04 & 1,45 & 1,83 & 0,72 & n.d. & n.d. & 0,60 & 0,90 & 0,25 \\
\hline $\mathrm{Eu}_{2} \mathrm{O}_{3}$ & 0,67 & 0,55 & 0,65 & 0,88 & 1,21 & 1,36 & 0,82 & n.d. & n.d. & n.d. & n.d. & n.d. \\
\hline $\mathrm{Gd}_{2} \mathrm{O}_{3}$ & 1,93 & 1,57 & 1,79 & 2,25 & 1,56 & 1,64 & 2,14 & n.d. & n.d. & 0,67 & 0,40 & 0,32 \\
\hline $\mathrm{Dy}_{2} \mathrm{O}_{3}$ & 0,01 & n.d. & 0,06 & n.d. & n.d. & n.d. & 0,04 & n.d. & n.d. & n.d. & n.d. & n.d. \\
\hline $\mathrm{Y}_{2} \mathrm{O}_{3}$ & n.d. & n.d. & n.d. & n.d. & n.d. & n.d. & n.d. & n.d. & n.d. & n.d. & n.d. & n.d. \\
\hline F & 1,29 & 1,33 & 0,85 & 1,17 & 0,66 & 0,28 & 0,88 & 2,03 & n.d. & 0,74 & n.d. & n.d. \\
\hline $\mathrm{Cl}$ & 0,05 & 0,03 & 0,06 & 0,05 & 0,06 & 0,13 & 0,09 & n.d. & n.d. & n.d. & n.d. & n.d. \\
\hline TOTAL & 92,85 & 85,92 & 88,88 & 89,95 & 89,40 & 90,22 & 86,51 & 100,00 & 100,01 & 100,00 & 99,99 & 100,02 \\
\hline $\mathrm{ETR}_{2} \mathrm{O}_{3}$ & 58,26 & 51,13 & 47,76 & 49,98 & 53,83 & 52,44 & 54,07 & 62,23 & 65,33 & 64,15 & 58,16 & 51,95 \\
\hline $\mathrm{Si}$ & - & 0,001 & 0,001 & - & - & - & 0,004 & - & - & - & - & - \\
\hline Th & 0,015 & 0,010 & 0,003 & - & - & 0,001 & 0,046 & - & - & - & - & - \\
\hline $\mathrm{Al}$ & 0,041 & 0,044 & 0,042 & 0,009 & 0,006 & 0,008 & 0,003 & - & - & - & - & - \\
\hline $\mathrm{Fe}^{2}$ & 0,024 & 0,023 & 0,025 & 0,004 & 0,002 & 0,004 & 0,030 & - & - & - & - & - \\
\hline $\mathrm{Mn}$ & - & - & - & - & - & - & 0,017 & - & - & - & - & - \\
\hline $\mathrm{Ca}$ & 0,359 & 0,484 & 0,449 & 0,262 & 0,322 & 0,251 & 0,066 & 0,131 & 0,103 & 0,085 & 0,268 & 0,298 \\
\hline $\mathrm{Ba}$ & - & - & - & - & - & - & 0,009 & 0,041 & - & - & - & - \\
\hline $\mathrm{Sr}$ & 0,009 & 0,015 & 0,016 & - & 0,003 & 0,003 & 0,045 & - & - & 0,077 & - & 0,064 \\
\hline $\mathrm{Pb}$ & 0,001 & - & - & - & - & - & - & - & - & - & - & - \\
\hline $\mathrm{P}$ & 0,803 & 0,795 & 0,925 & 0,865 & 0,922 & 0,954 & 0,896 & 0,940 & 1,021 & 0,973 & 1,004 & 1,017 \\
\hline $\mathrm{La}$ & 0,277 & 0,234 & 0,188 & 0,158 & 0,278 & 0,261 & 0,227 & 0,213 & 0,244 & 0,242 & 0,166 & 0,184 \\
\hline $\mathrm{Ce}$ & 0,402 & 0,385 & 0,301 & 0,334 & 0,208 & 0,165 & 0,418 & 0,475 & 0,506 & 0,469 & 0,409 & 0,376 \\
\hline $\operatorname{Pr}$ & 0,039 & 0,036 & 0,031 & 0,030 & 0,051 & 0,047 & 0,042 & - & - & 0,034 & 0,045 & - \\
\hline $\mathrm{Nd}$ & 0,164 & 0,162 & 0,145 & 0,144 & 0,224 & 0,225 & 0,186 & 0,186 & 0,147 & 0,145 & 0,135 & 0,107 \\
\hline $\mathrm{Sm}$ & 0,005 & 0,007 & 0,004 & 0,014 & 0,021 & 0,025 & 0,012 & - & - & 0,008 & 0,011 & 0,003 \\
\hline $\mathrm{Eu}$ & 0,010 & 0,009 & 0,009 & 0,012 & 0,017 & 0,019 & 0,013 & - & - & - & - & - \\
\hline $\mathrm{Gd}$ & 0,028 & 0,024 & 0,024 & 0,030 & 0,022 & 0,022 & 0,034 & - & - & 0,009 & 0,005 & 0,004 \\
\hline Dy & - & - & 0,001 & - & - & - & 0,001 & - & - & - & - & - \\
\hline Y & - & - & - & - & - & - & - & - & - & - & - & - \\
\hline Cations & 2,196 & 2,242 & 2,177 & 2,065 & 2,122 & 2,076 & 2,060 & 2,015 & 2,021 & 2,042 & 2,174 & 2,224 \\
\hline
\end{tabular}

Rock types: 10-12: metasomatized perovskite bebedourite, 20-22 and 36: bebedourite. 40: magnesiocarbonatite. 41: metasomatized perovskite. 45,46 and 49: bebedourite. Cations per formula unit calculated on the basis of 4 oxygen. . .d. $=$ not detected. Ps $=$ pseudomorphic; Met = metasomatic. 


\subsubsection{Other REE-bearing minerals}

REE bearing carbonates are described in APIP carbonatites (Morteani and Preinfalk. 1996; Oliveira and Imbernon, 1998). Small inclusions $(<5 \mu \mathrm{m})$ of strontianite and ancyllite were observed in this work, in calcium and magnesium carbonatite veins, similarly to occurrences described in other carbonatites (Mariano, 1989; Hogarth et al, 1985). Normalized EDS analyses indicate traces of REE in strontianite up to $34 \%$ wt. of $\mathrm{Ce}_{2} \mathrm{O}_{3}$ in ancyllite. It is known that REE-carbonates leaching during hydrothermalism or weathering releases REE into the system, which might lead to their precipitation as Al-phosphates in the weathering profile, but the extent and contribution of this process in Salitre needs further studies to be determined.

Cerianite was identified in the Lower Alloterite horizon, associated with monazite. Cerianite was described in Catalão I (Morteani and Preinfalk, 1996; Neumann, 1999) as result of REE liberated from monazite dissolution, followed by $\mathrm{Ce}^{3+}$ oxidation to $\mathrm{Ce}^{4+}$ and the precipitation of the latter as an oxide (Toledo et al, 2004).

\subsubsection{Titanium mineralogy and mineral chemistry}

The common titanium-bearing phases in the Salitre deposit are perovskite, titanite, Ti-rich garnet (melanite), ilmenite and anatase. In this work, we focus on the main titanium carriers within the fresh rock (perovskite) and alterites (anatase) and their relationship. Titanite and Ti-rich garnet are not present in our studied perovskite-rich bebedourite samples. Some silicate minerals such as pyroxene and phlogopite (Barbosa, 2012) contain only minor titanium amounts and were not considered in this study.

Perovskite alteration to anatase may occur both during late-stage carbo-hydrothermal activity and during weathering (e.g. Ribeiro, 2008). In our samples, the occurrence of metasomatic anatase in the fresh rocks is associated with the late-stage intrusion of the oxidizing, barite- and strontianite-rich D4 carbonatite (Barbosa, 2012). This type of anatase seems to be specifically related to D4, since perovskite remains unaltered in bebedourites

intensely metasomatized by calciocarbonatite. Similarly, metasomatic anatase does not appear in connection with the intrusions of the less evolved Salitre magnesiocarbonatites C1 and $\mathrm{C} 2$.

\subsubsection{Perovskite}


Perovskite $\left(\mathrm{CaTiO}_{3}\right)$ is the main carrier of titanium in the fresh rock horizon, as it is a main constituent of B1a type bebedourites and is a trace constituent of P1 type phoscorites. Perovskite analyzed from B1a bebedourite displays a limited composition range close to the sensu strictu perovskite, as described by Barbosa (2009; 2012). Minor REE substitutions occurs, with the loparite molecule ranging up to $8 \%$. Table 2-5 shows representative analysis of Perovskite from B1a bebedourites for Salitre I. 
Table 2-5: Representative perovskite analysis from B1a Salitre bebedourites.

\begin{tabular}{|c|c|c|c|c|c|c|c|c|c|c|}
\hline Analysis & 1 & 2 & 3 & 4 & 6 & 7 & 8 & 9 & 10 & 12 \\
\hline source & $W D S$ & $W D S$ & $W D S$ & $W D S$ & $W D S$ & $W D S$ & $W D S$ & $W D S$ & $W D S$ & $W D S$ \\
\hline $\mathrm{SiO}_{2}$ & n.d. & n.d. & n.d. & n.d. & n.d. & 0,02 & 0,01 & n.d. & 0,02 & n.d. \\
\hline $\mathrm{TiO}_{2}$ & 57,08 & 56,76 & 56,71 & 56,95 & 57,09 & 56,84 & 57,29 & 56,91 & 57,05 & 55,96 \\
\hline $\mathrm{Al}_{2} \mathrm{O}_{3}$ & 0,06 & 0,04 & 0,04 & 0,06 & 0,04 & 0,08 & 0,07 & 0,09 & 0,09 & 0,10 \\
\hline $\mathrm{FeO}$ & 1,22 & 1,46 & 1,09 & 1,27 & 1,14 & 1,24 & 1,23 & 1,23 & 1,29 & 1,49 \\
\hline $\mathrm{MnO}$ & n.d. & n.d. & 0,03 & 0,10 & 0,01 & n.d. & n.d. & 0,07 & n.d. & 0,05 \\
\hline $\mathrm{MgO}$ & 0,04 & n.d. & n.d. & 0,02 & 0,01 & 0,02 & 0,05 & n.d. & 0,02 & 0,04 \\
\hline $\mathrm{CaO}$ & 39,07 & 38,19 & 38,61 & 38,86 & 38,65 & 38,45 & 38,33 & 38,83 & 38,51 & 37,90 \\
\hline $\mathrm{Na}_{2} \mathrm{O}$ & 0,24 & 0,28 & 0,27 & 0,22 & 0,24 & 0,33 & 0,27 & 0,33 & 0,38 & 0,40 \\
\hline $\mathrm{ThO}_{2}$ & n.d. & n.d. & 0,02 & 0,02 & 0,02 & 0,05 & 0,13 & 0,08 & 0,05 & 0,08 \\
\hline $\mathrm{ZrO}_{2}$ & n.d. & 0,10 & 0,20 & 0,15 & n.d. & 0,16 & 0,04 & n.d. & n.d. & 0,13 \\
\hline $\mathrm{SrO}$ & 0,17 & 0,18 & 0,37 & 0,09 & 0,35 & 0,27 & 0,16 & 0,17 & 0,10 & 0,42 \\
\hline $\mathrm{Nb}_{2} \mathrm{O}_{5}$ & 0,47 & 0,25 & 0,37 & 0,46 & 0,39 & 0,45 & 0,45 & 0,37 & 0,39 & 0,76 \\
\hline $\mathrm{Ta}_{2} \mathrm{O}_{5}$ & n.d. & n.d. & n.d. & n.d. & n.d. & n.d. & n.d. & n.d. & n.d. & n.d. \\
\hline $\mathrm{La}_{2} \mathrm{O}_{3}$ & 0,57 & 0,58 & 0,58 & 0,50 & 0,48 & 0,58 & 0,56 & 0,47 & 0,59 & 0,73 \\
\hline $\mathrm{Ce}_{2} \mathrm{O}_{3}$ & 0,84 & 0,90 & 1,08 & 0,98 & 1,02 & 0,98 & 0,84 & 0,87 & 0,82 & 1,32 \\
\hline $\mathrm{Pr}_{2} \mathrm{O}_{3}$ & 0,11 & 0,10 & 0,17 & 0,08 & 0,07 & 0,08 & 0,07 & 0,07 & 0,10 & 0,12 \\
\hline $\mathrm{Nd}_{2} \mathrm{O}_{3}$ & 0,45 & 0,57 & 0,61 & 0,46 & 0,72 & 0,45 & 0,39 & 0,46 & 0,44 & 0,63 \\
\hline Total & 100,31 & 99,40 & 100,13 & 100,20 & 100,21 & 99,99 & 99,85 & 99,95 & 99,83 & 100,11 \\
\hline $\mathrm{Si}$ & - & - & - & - & - & - & - & - & - & - \\
\hline $\mathrm{Al}$ & 0,976 & 0,978 & 0,977 & 0,975 & 0,979 & 0,977 & 0,981 & 0,976 & 0,978 & 0,967 \\
\hline $\mathrm{Ti}$ & 0,002 & 0,001 & 0,001 & 0,002 & 0,001 & 0,002 & 0,002 & 0,002 & 0,002 & 0,003 \\
\hline $\mathrm{Fe} 3$ & 0,021 & 0,025 & 0,019 & 0,022 & 0,019 & 0,021 & 0,021 & 0,021 & 0,022 & 0,026 \\
\hline $\mathrm{Mn}$ & - & - & - & 0,002 & - & - & - & 0,001 & - & 0,001 \\
\hline $\mathrm{Mg}$ & 0,001 & - & - & 0,001 & - & 0,001 & 0,002 & - & 0,001 & 0,001 \\
\hline $\mathrm{Ca}$ & 0,952 & 0,937 & 0,947 & 0,947 & 0,944 & 0,942 & 0,935 & 0,948 & 0,941 & 0,933 \\
\hline $\mathrm{Na}$ & 0,010 & 0,012 & 0,012 & 0,009 & 0,011 & 0,015 & 0,012 & 0,015 & 0,017 & 0,018 \\
\hline Th & - & - & - & - & - & - & 0,001 & - & - & - \\
\hline $\mathrm{Zr}$ & - & 0,001 & 0,002 & 0,002 & - & 0,002 & - & - & - & 0,001 \\
\hline $\mathrm{Sr}$ & 0,002 & 0,002 & 0,005 & 0,001 & 0,005 & 0,004 & 0,002 & 0,002 & 0,001 & 0,006 \\
\hline $\mathrm{Nb}$ & 0,005 & 0,003 & 0,004 & 0,005 & 0,004 & 0,005 & 0,005 & 0,004 & 0,004 & 0,008 \\
\hline $\mathrm{Ta}$ & - & - & - & - & - & - & - & - & - & - \\
\hline $\mathrm{La}$ & 0,005 & 0,005 & 0,005 & 0,004 & 0,004 & 0,005 & 0,005 & 0,004 & 0,005 & 0,006 \\
\hline $\mathrm{Ce}$ & 0,007 & 0,008 & 0,009 & 0,008 & 0,008 & 0,008 & 0,007 & 0,007 & 0,007 & 0,011 \\
\hline $\operatorname{Pr}$ & 0,001 & 0,001 & 0,001 & 0,001 & 0,001 & 0,001 & 0,001 & 0,001 & 0,001 & 0,001 \\
\hline $\mathrm{Nd}$ & 0,004 & 0,005 & 0,005 & 0,004 & 0,006 & 0,004 & 0,003 & 0,004 & 0,004 & 0,005 \\
\hline Cations & 1,985 & 1,978 & 1,987 & 1,982 & 1,983 & 1,986 & 1,975 & 1,985 & 1,983 & 1,988 \\
\hline
\end{tabular}

Cations per formula unit calculated on the basis of 3 oxygen. n.d. $=$ not detected. 


\subsubsection{Anatase}

Anatase is a $\mathrm{TiO}_{2}$ polymorph, composed of $\mathrm{Ti}^{4+}$ and $\mathrm{O}^{2+}$ octahedra. Minor $\mathrm{Fe}, \mathrm{Sn}, \mathrm{Nb}$ and Ta substitutions are known (Deer et al, 1992). WDS analysis shows that the anatase from the Salitre weathering profile contains minor amounts of $\mathrm{Fe}_{2} \mathrm{O}_{3}$ (up to 4.46 wt. \%) and $\mathrm{Nb}_{2} \mathrm{O}_{5}$ (1.59 wt. \%), with no detectable Ta. Minor amounts of $\mathrm{Al}_{2} \mathrm{O}_{3}$ (4.88 wt. \%), $\mathrm{P}_{2} \mathrm{O}_{5}$ (2.88 wt. $\%)$ and $\mathrm{REE}_{2} \mathrm{O}_{3}(2.0$ wt. \%) and trace amounts of $\mathrm{BaO}(0.49$ wt. \%) and $\mathrm{CaO}(0.44$ wt. \%) were also detected. Metasomatic anatase shows limited chemical variation: up to 3 wt. \%. $\mathrm{CaO}$ and 2.2 wt. $\% \mathrm{Fe}_{2} \mathrm{O}_{3}$. (EDS analysis).

Reliable WDS/EDS analysis from both metasomatic and supergenic anatase are difficult to obtain. Metasomatic anatase presents a skeletal residual structure often associated with other minerals such as monazite and dolomite; supergenic anatase is porous and frequently associated with supergenic monazite. Maximum care was taken to avoid interference from such associations during analysis.

There is no visible correlation between $\mathrm{Ti}$ and the trace amounts of $\mathrm{Nb}$ in the anatase (Figure $2.14 \mathrm{a} / \mathrm{b}$ ). Fe substitution is most common in Lower Alloterite samples, suggesting that supergenic anatase might incorporate easily available elements. In less evolved weathering horizons, such as the upper micaceous isalterite, and in the metasomatic anatase, Fe-Ti substitution is restricted. The presence of elements such as $\mathrm{Ca}, \mathrm{Al}$ and $\mathrm{P}$, which are not expected as Ti substitutes, might be due to interference from microinclusions of other mineral phases during analysis. The strong Al-Ti and P-Ti correlation, mainly in anatase from the alloterite horizon might be associated with aluminous phosphate inclusions. Ca values are highest in metasomatic anatase, probably indicating an incomplete transformation of the perovskite. $\mathrm{Nb}+\mathrm{Fe}$ substitutions are more common in more evolved lower alloterite anatase, when compared with the original perovskite (Figure $2.14 \mathrm{~g}$ ). Anatase contains less REE than perovskite, since the rare earths are removed from the latter during weathering to form acicular monazite (Figure 2.14 h). 
Table 2-6. Representative anatase analysis from Salitre alterites.

\begin{tabular}{|c|c|c|c|c|c|c|c|c|c|c|c|}
\hline Analysis & 1 & 3 & 5 & 6 & 7 & 8 & 9 & 11 & 13 & 14 & 15 \\
\hline $\mathrm{SiO}_{2}$ & 0,98 & 0,02 & 0,07 & 0,18 & 0,48 & 0,14 & 0,09 & 0,15 & 0,08 & 0,32 & 0,79 \\
\hline $\mathrm{TiO}_{2}$ & 94,98 & 88,70 & 87,09 & 86,22 & 87,13 & 86,08 & 86,67 & 83,30 & 87,86 & 87,75 & 91,43 \\
\hline $\mathrm{ZrO}_{2}$ & 0,05 & 0,17 & 0,15 & 0,02 & 0,24 & 0,39 & 0,15 & 0,26 & 0,10 & 0,19 & 0,08 \\
\hline $\mathrm{ThO}_{2}$ & n.d. & n.d. & 0,09 & 0,07 & 0,01 & 0,03 & n.d. & 0,01 & 0,09 & 0,01 & 0,02 \\
\hline $\mathrm{Al}_{2} \mathrm{O}_{3}$ & 0,03 & 1,47 & 1,59 & 3,39 & 3,53 & 3,64 & 3,30 & 4,88 & 4,08 & 1,97 & 0,08 \\
\hline $\mathrm{V}_{2} \mathrm{O}_{3}$ & 0,85 & 0,88 & 0,89 & 0,76 & 0,76 & 0,91 & 0,63 & 0,72 & 0,84 & 0,84 & 0,93 \\
\hline $\mathrm{Cr}_{2} \mathrm{O}_{3}$ & n.d. & n.d. & 0,00 & 0,00 & 0,00 & 0,00 & 0,00 & 0,05 & 0,00 & 0,00 & 0,00 \\
\hline $\mathrm{Fe}_{2} \mathrm{O}_{3}$ & 0,87 & 3,90 & 3,90 & 4,38 & 3,66 & 3,48 & 3,31 & 2,63 & 2,97 & 4,46 & 3,16 \\
\hline $\mathrm{MnO}$ & 0,02 & 0,58 & 0,48 & 0,17 & 0,07 & 0,34 & 0,17 & 0,09 & 0,07 & 0,07 & 0,07 \\
\hline $\mathrm{CaO}$ & 0,32 & 0,05 & 0,14 & 0,12 & 0,08 & 0,07 & 0,13 & 0,44 & 0,07 & 0,07 & 0,12 \\
\hline $\mathrm{BaO}$ & 0,51 & 0,51 & 0,62 & 0,37 & 0,26 & 0,21 & 0,38 & 0,36 & 0,34 & 0,36 & 0,38 \\
\hline $\mathrm{P}_{2} \mathrm{O}_{5}$ & 0,08 & 1,89 & 2,29 & 2,60 & 2,66 & 2,91 & 2,23 & 3,76 & 2,60 & 1,89 & 0,01 \\
\hline $\mathrm{Nb}_{2} \mathrm{O}_{5}$ & 1,18 & 1,21 & 1,07 & 0,54 & 0,79 & 1,16 & 1,27 & 0,75 & 0,58 & 1,07 & 1,77 \\
\hline $\mathrm{La}_{2} \mathrm{O}_{3}$ & n.d. & n.d. & 0,22 & 0,11 & n.d. & n.d. & n.d. & 0,43 & n.d. & n.d. & n.d. \\
\hline $\mathrm{Ce}_{2} \mathrm{O}_{3}$ & n.d. & n.d. & 0,05 & n.d. & n.d. & n.d. & n.d. & 0,96 & n.d. & n.d. & n.d. \\
\hline $\mathrm{Pr} 2 \mathrm{O}_{3}$ & 0,05 & 0,02 & 0,06 & n.d. & n.d. & 0,01 & 0,04 & 0,21 & n.d. & n.d. & 0,05 \\
\hline $\mathrm{Nd}_{2} \mathrm{O}_{3}$ & n.d. & n.d. & 0,31 & 0,02 & n.d. & n.d. & n.d. & 0,41 & 0,05 & n.d. & n.d. \\
\hline TOTAL & 100,21 & 99,49 & 99,03 & 99,07 & 99,85 & 99,41 & 98,48 & 99,51 & 99,87 & 99,06 & 98,99 \\
\hline $\mathrm{Si}$ & 0,013 & - & 0,001 & 0,002 & 0,006 & 0,002 & 0,001 & 0,002 & 0,001 & 0,004 & 0,011 \\
\hline $\mathrm{Ti}$ & 0,957 & 0,902 & 0,892 & 0,872 & 0,870 & 0,865 & 0,882 & 0,840 & 0,877 & 0,893 & 0,939 \\
\hline $\mathrm{Zr}$ & - & 0,001 & 0,001 & - & 0,002 & 0,003 & 0,001 & 0,002 & 0,001 & 0,001 & 0,001 \\
\hline Th & - & - & - & - & - & - & - & - & - & - & \\
\hline $\mathrm{Al}$ & - & 0,023 & 0,026 & 0,054 & 0,055 & 0,057 & 0,053 & 0,077 & 0,064 & 0,031 & 0,001 \\
\hline V & 0,009 & 0,010 & 0,010 & 0,008 & 0,008 & 0,010 & 0,007 & 0,008 & 0,009 & 0,009 & 0,010 \\
\hline $\mathrm{Cr}$ & - & - & - & - & - & - & - & 0,001 & - & - & - \\
\hline $\mathrm{Fe} 3$ & 0,009 & 0,040 & 0,040 & 0,044 & 0,037 & 0,035 & 0,034 & 0,027 & 0,030 & 0,045 & 0,032 \\
\hline $\mathrm{Mn}$ & - & 0,007 & 0,005 & 0,002 & 0,001 & 0,004 & 0,002 & 0,001 & 0,001 & 0,001 & 0,001 \\
\hline $\mathrm{Ca}$ & 0,005 & 0,001 & 0,002 & 0,002 & 0,001 & 0,001 & 0,002 & 0,006 & 0,001 & 0,001 & 0,002 \\
\hline $\mathrm{Ba}$ & 0,003 & 0,003 & 0,003 & 0,002 & 0,001 & 0,001 & 0,002 & 0,002 & 0,002 & 0,002 & 0,002 \\
\hline $\mathrm{P}$ & 0,001 & 0,022 & 0,026 & 0,030 & 0,030 & 0,033 & 0,026 & 0,043 & 0,029 & 0,022 & \\
\hline $\mathrm{Nb}$ & 0,007 & 0,007 & 0,007 & 0,003 & 0,005 & 0,007 & 0,008 & 0,005 & 0,003 & 0,007 & 0,011 \\
\hline $\mathrm{La}$ & - & - & 0,001 & 0,001 & - & - & - & 0,002 & - & - & \\
\hline $\mathrm{Ce}$ & - & - & - & - & - & - & - & 0,005 & - & - & \\
\hline $\operatorname{Pr}$ & - & - & - & - & - & - & - & 0,001 & - & - & \\
\hline $\mathrm{Nd}$ & - & - & 0,002 & - & - & - & - & 0,002 & - & - & - \\
\hline Cations & 1,009 & 1,017 & 1,017 & 1,023 & 1,021 & 1,019 & 1,020 & 1,025 & 1,022 & 1,017 & 1,011 \\
\hline
\end{tabular}

Sample 1: top micaceous isalterite 130m depth; all other samples lower alloterite: 2 to $5,117 \mathrm{~m}$ depth; 6 to $13,88 \mathrm{~m}$ depth; 14 to $15,80 \mathrm{~m}$ depth. Cations per formula unit calculated on the basis of 2 oxygen. n.d. = not detected.. 

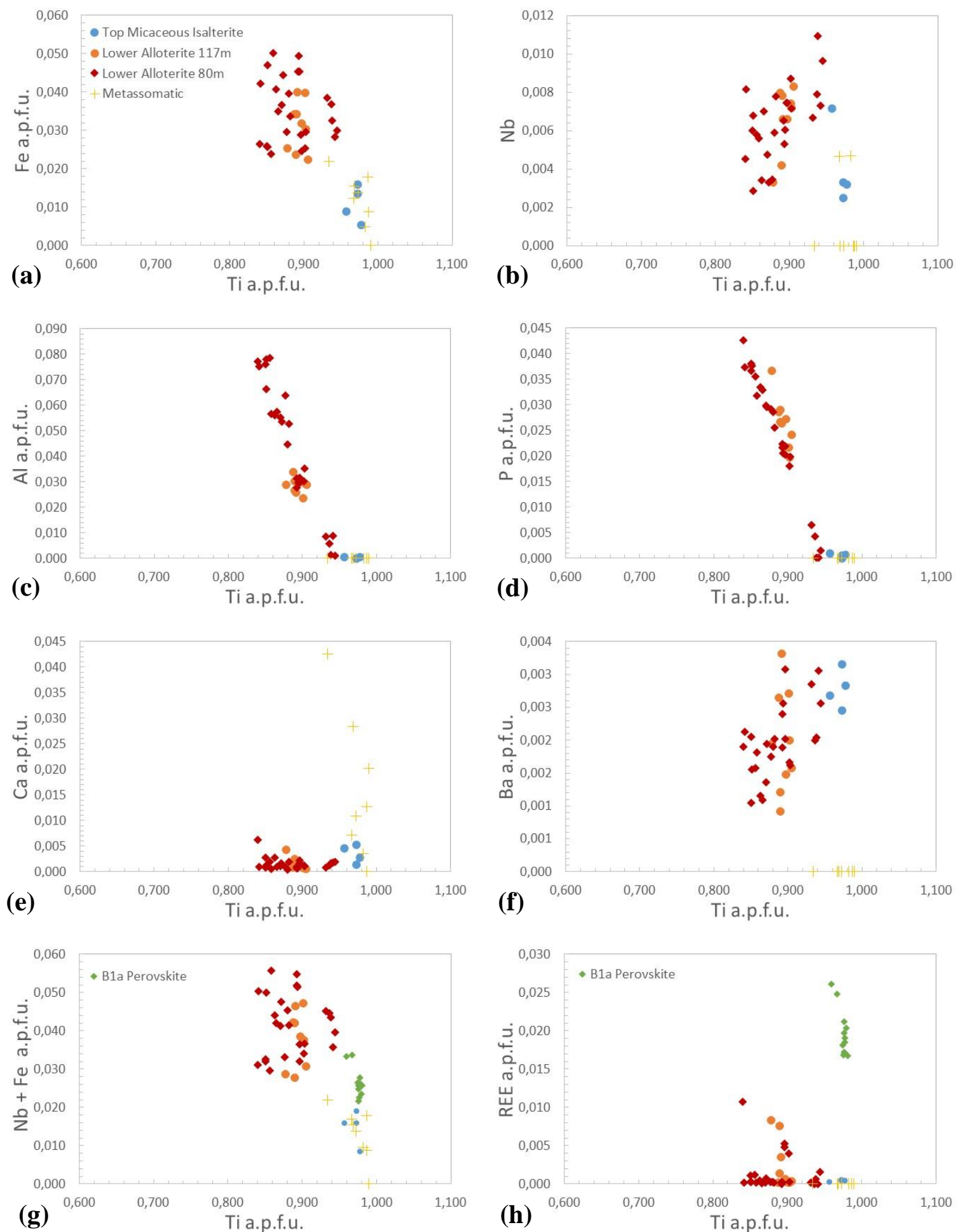

Figure 2.14: Substitutions and compositional trends for anatase in Salitre weathering profile. Cross-cut symbols represent EDS analysis, and circle/diamonds represent WDS analysis. Legend in figure a. a.p.f.u.= atoms per formula unit. 


\subsubsection{Other Titanium-bearing minerals}

Ilmenite is the other titanium phase identified in the samples, as exsolution lamellae in magnetite. Occasionally, ilmenite may form rims around perovskite crystals. EDS analysis indicates high $\mathrm{Mn}$ (up to $4.9 \%$ wt.) and $\mathrm{Mg}$ (up to $12.8 \%$ wt.) contents. These values are similar to those observed by Gaspar and Willie (1983) for ilmenite associated with magnetite in the Jacupiranga carbonatites.

\subsection{Whole rock and laterite geochemistry}

\subsubsection{Major Elements}

Chemical analysis from selected samples are shown in Table 2-7. Fresh bebedourites are ultrabasic rocks, with high contents of $\mathrm{MgO}, \mathrm{Fe}_{2} \mathrm{O}_{3}, \mathrm{TiO}_{2}$ and $\mathrm{CaO}$, and low contents of $\mathrm{Al}_{2} \mathrm{O}_{3}$ and $\mathrm{Na}_{2} \mathrm{O}$. The amounts of $\mathrm{K}_{2} \mathrm{O}$ and carbonate depend on the intensity of the carbonatite metasomatism affecting the rock. The altered rock shows similar composition to fresh rock. The analyzed carbonatite sample is a fresh-rock calciocarbonatite with minor $\mathrm{MgO}$ and trace amounts of $\mathrm{P}_{2} \mathrm{O}_{5}, \mathrm{BaO}, \mathrm{SrO}$ and $\mathrm{S}$.

The isalterite horizon shows a consistent decrease in $\mathrm{MgO}$ and $\mathrm{K}_{2} \mathrm{O}$ due to the alteration of olivine, diopside and phlogopite. $\mathrm{CaO}$ and $\mathrm{P}_{2} \mathrm{O}_{5}$ are high, due to abundant apatite in this level. High $\mathrm{CaO} / \mathrm{P}_{2} \mathrm{O}_{5}$ ratios, averaging 1.6 indicate the presence of $\mathrm{CaO}$ phases other than apatite. Carbonates are completely leached in the isalterite but some $\mathrm{CaO}$ is still preserved in residual perovskite and diopside, with trace values contained in newly-formed clay minerals. The lower micaceous isalterite is characterized by higher average $\mathrm{SiO}_{2}$ and $\mathrm{MgO}$ levels than other isalterite horizons, due to the presence of vermiculite. Upper Micaceous Isalterite and Oxidized Isalterite have similar geochemistry, with increasing $\mathrm{Fe}_{2} \mathrm{O}_{3}$ and $\mathrm{P}_{2} \mathrm{O}_{5}$ to the top of the isalteritic profile. 
Table 2-7. Representative whole-rock chemical analyses from selected samples of the weathering profile over the Salitre Complex.

\begin{tabular}{|c|c|c|c|c|c|c|c|c|c|c|c|c|c|c|c|}
\hline \multirow[b]{2}{*}{ Depth $(\mathrm{m})$} & \multicolumn{5}{|c|}{ Fresh Rock } & \multicolumn{2}{|c|}{ Lower Mic. Isalt. } & \multirow{2}{*}{\begin{tabular}{c}
$\begin{array}{c}\text { Upper } \\
\text { Mic. } \\
\text { Isalt. }\end{array}$ \\
\multicolumn{2}{|c|}{129,8} \\
\end{tabular}} & \multirow{2}{*}{\begin{tabular}{|c|} 
Ox.Isalt. \\
120,9 \\
\end{tabular}} & \multicolumn{4}{|c|}{ Lower Alloterite } & \multicolumn{2}{|c|}{ Upper Alloterite } \\
\hline & 167,35 & 166,25 & 164,9 & 106,5 & 101,4 & 157,1 & 145 & & & 114,2 & 93,5 & 80,1 & 71 & 57 & 5,8 \\
\hline Analysis & 1 & 2 & 3 & 15 & 16 & 4 & 5 & 6 & 7 & 8 & 9 & 10 & 11 & 12 & 13 \\
\hline $\mathrm{SiO}_{2}$ & 25,11 & 0,64 & 18,14 & 10,75 & 42,07 & 26,80 & 20,97 & 6,86 & 1,13 & 20,70 & 3,98 & 11,62 & 5,75 & 28,56 & 13,33 \\
\hline $\mathrm{TiO}_{2}$ & 8,79 & 0,55 & 8,90 & 11,28 & 5,36 & 7,78 & 10,22 & 11,68 & 5,23 & 13,22 & 28,21 & 7,78 & 18,25 & 7,53 & 9,16 \\
\hline $\mathrm{Al}_{2} \mathrm{O}_{3}$ & 3,98 & 0,01 & 3,85 & 0,39 & 0,68 & 4,28 & 5,96 & 2,97 & 2,04 & 3,03 & 3,73 & 9,23 & 10,28 & 27,28 & 34,84 \\
\hline $\mathrm{Fe}_{2} \mathrm{O}_{3}$ & 10,99 & 3,87 & 14,32 & 11,44 & 12,73 & 8,89 & 12,74 & 21,88 & 28,79 & 40,81 & 46,14 & 31,43 & 46,12 & 19,37 & 21,53 \\
\hline $\mathrm{MnO}$ & 0,27 & 0,16 & 0,35 & 0,57 & 0,15 & 0,35 & 0,28 & 0,50 & 2,70 & 1,40 & 1,06 & 7,24 & 0,44 & 0,14 & 0,10 \\
\hline $\mathrm{MgO}$ & 17,08 & 3,60 & 15,43 & 16,14 & 13,55 & 24,58 & 15,40 & 4,08 & 0,51 & 1,60 & 2,19 & 0,88 & 1,13 & 0,29 & 0,24 \\
\hline $\mathrm{CaO}$ & 13,64 & 48,45 & 16,12 & 17,92 & 23,16 & 9,28 & 12,16 & 25,59 & 21,14 & 0,55 & 0,54 & 0,47 & 0,99 & 0,27 & 0,06 \\
\hline $\mathrm{Na}_{2} \mathrm{O}$ & 0,16 & 0,03 & 0,14 & 0,29 & 0,37 & 0,12 & 0,05 & 0,12 & 0,14 & 0,05 & 0,03 & 0,06 & 0,04 & 0,04 & 0,03 \\
\hline $\mathrm{K}_{2} \mathrm{O}$ & 6,01 & 0,05 & 4,05 & 1,86 & 0,33 & 0,29 & 0,28 & 0,08 & 0,02 & 0,05 & 0,03 & 0,05 & 0,03 & 0,19 & 0,04 \\
\hline $\mathrm{P}_{2} \mathrm{O}_{5}$ & 4,22 & 0,39 & 7,43 & 2,36 & 1,19 & 5,28 & 6,93 & 16,97 & 19,35 & 4,07 & 3,64 & 4,81 & 4,84 & 1,85 & 0,70 \\
\hline $\mathrm{BaO}$ & 0,17 & 0,22 & 0,16 & 0,77 & 0,05 & 0,05 & 0,06 & 0,12 & 0,34 & 0,37 & 0,20 & 1,39 & 0,32 & 0,24 & 0,08 \\
\hline $\mathrm{SrO}$ & 0,28 & 1,29 & 0,42 & 0,51 & 0,13 & 0,15 & 0,17 & 0,32 & 0,64 & 0,45 & 0,46 & 0,69 & 0,55 & 0,28 & 0,09 \\
\hline LOI & 8,93 & 38,00 & 9,67 & 23,20 & 1,16 & 12,20 & 14,35 & 6,53 & 7,16 & 5,51 & 5,80 & 11,85 & 8,52 & 13,30 & 19,00 \\
\hline TOTAL & 99,63 & 97,25 & 98,98 & 97,49 & 100,95 & 100,05 & 99,57 & 97,72 & 89,21 & 91,84 & 96,04 & 87,51 & 97,28 & 99,35 & 99,22 \\
\hline S & $<0,01$ & 1,5 & $<0,01$ & 0,1 & 0,0 & $<0,01$ & $<0,01$ & $<0,01$ & $<0,01$ & 0,0 & $<0,01$ & 0,0 & 0,0 & 0,0 & 0,0 \\
\hline V & 123,2 & 41,1 & 280,3 & 374,9 & 217,8 & 135,7 & 194,6 & 419,5 & 449,9 & 874,7 & 908,7 & 658,7 & 765,9 & 699,8 & 805,1 \\
\hline $\mathrm{Cr}$ & 73,1 & 43,8 & 102,3 & 116,9 & 58,5 & 58,5 & 131,5 & 87,7 & 233,8 & 306,9 & 321,5 & 233,8 & 277,7 & 350,8 & 423,8 \\
\hline $\mathrm{Ni}$ & 140,0 & 22,9 & 146,3 & 196,0 & 66,2 & 137,4 & 249,4 & 252,0 & 356,3 & 315,6 & 376,7 & $1.261,0$ & 202,3 & 114,5 & 67,4 \\
\hline $\mathrm{Rb}$ & 241,7 & 1,9 & 172,2 & 75,9 & 8,3 & 11,6 & 10,6 & 5,4 & 1,1 & 3,2 & 1,9 & 2,2 & 1,5 & 17,4 & 1,5 \\
\hline $\mathrm{Sr}$ & $2.589,91$ & $11.826,0$ & $4.009,0$ & $4.966,9$ & $1.188,5$ & $1.448,7$ & $1.844,9$ & $3.110,2$ & $6.918,2$ & $4.825,0$ & $4.813,2$ & $7.663,2$ & $5.463,6$ & $2.767,3$ & 851,5 \\
\hline $\mathrm{Y}$ & 57,4 & 66,5 & 79,5 & 74,8 & 45,6 & 49,8 & 73,0 & 149,8 & 921,9 & 811,5 & 383,5 & $1.269,9$ & 345,4 & 198,1 & 71,7 \\
\hline $\mathrm{Zr}$ & 159,4 & 75,6 & 356,6 & 258,0 & 283,7 & 367,4 & 229,6 & 502,5 & 909,1 & $1.762,8$ & $1.398,1$ & 826,7 & $1.306,2$ & $1.648,0$ & $1.675,0$ \\
\hline $\mathrm{Nb}$ & $1.101,5$ & 773,9 & $1.552,1$ & $1.407,6$ & 432,0 & $1.552,1$ & $1.105,8$ & $1.916,9$ & $5.865,1$ & $6.866,4$ & $4.434,6$ & $4.005,4$ & $2.746,6$ & $1.088,6$ & $1.057,1$ \\
\hline $\mathrm{Ba}$ & $1.618,9$ & $1.808,7$ & $1.490,5$ & $7.659,2$ & 284,7 & 379,6 & 427,6 & $1.010,4$ & $3.662,1$ & $4.064,1$ & $1.981,8$ & $13.900,0$ & $3.237,9$ & $2.478,6$ & 755,9 \\
\hline $\mathrm{La}$ & 772,9 & 354,2 & 390,5 & $2.697,4$ & 546,5 & 435,1 & 704,9 & $1.841,3$ & $8.936,7$ & $5.242,4$ & $3.776,4$ & $12.314,4$ & $2.638,8$ & $1.012,1$ & 737,7 \\
\hline $\mathrm{Ce}$ & $1.493,4$ & 754,3 & 864,4 & $5.095,2$ & 893,7 & 906,6 & $1.358,7$ & $3.584,2$ & $15.929,7$ & $10.951,7$ & $7.226,9$ & $16.749,6$ & $5.095,2$ & $1.862,4$ & $1.593,0$ \\
\hline $\operatorname{Pr}$ & 160,9 & 82,2 & 98,9 & 534,8 & 85,7 & 101,2 & 149,2 & 372,2 & $1.755,5$ & $1.287,3$ & 729,1 & $1.521,4$ & 548,9 & 200,1 & 107,6 \\
\hline $\mathrm{Nd}$ & 598,4 & 321,9 & 389,6 & $1.848,7$ & 306,8 & 391,9 & 564,5 & $1.370,5$ & $5.528,7$ & $4.549,0$ & $2.589,4$ & $4.887,2$ & $2.000,4$ & 744,2 & 345,3 \\
\hline $\mathrm{Sm}$ & 82,2 & 51,0 & 58,7 & 184,4 & 47,3 & 59,1 & 83,4 & 196,0 & 818,7 & 700,4 & 381,5 & 613,4 & 281,8 & 114,5 & 45,5 \\
\hline $\mathrm{Eu}$ & 20,5 & 14,0 & 15,7 & 41,2 & 13,3 & 15,2 & 20,9 & 50,3 & 218,3 & 187,6 & 104,8 & 155,7 & 80,9 & 30,1 & 11,6 \\
\hline $\mathrm{Gd}$ & 43,9 & 31,7 & 35,3 & 80,6 & 33,9 & 34,6 & 48,3 & 105,9 & 492,2 & 420,7 & 240,9 & 342,3 & 185,6 & 79,0 & 27,4 \\
\hline $\mathrm{Tb}$ & 4,6 & 3,8 & 4,1 & 7,4 & 4,2 & 3,8 & 5,0 & 11,0 & 53,8 & 47,8 & 28,0 & 40,9 & 20,1 & 9,5 & 3,5 \\
\hline Dy & 18,9 & 16,6 & 19,1 & 28,0 & 16,1 & 15,8 & 22,2 & 47,4 & 239,9 & 212,3 & 114,4 & 211,2 & 87,1 & 46,3 & 16,5 \\
\hline Ho & 2,6 & 2,6 & 3,2 & 3,3 & 2,2 & 2,2 & 3,1 & 6,3 & 35,5 & 31,0 & 16,2 & 41,8 & 14,7 & 8,3 & 2,8 \\
\hline Er & 4,7 & 5,1 & 6,6 & 6,1 & 4,1 & 4,1 & 5,9 & 11,8 & 75,6 & 65,2 & 32,2 & 107,5 & 29,8 & 19,2 & 7,0 \\
\hline $\mathrm{Tm}$ & 0,4 & 0,6 & 0,7 & 0,6 & 0,4 & 0,4 & 0,5 & 1,1 & 8,3 & 7,0 & 3,2 & 12,8 & 2,8 & 2,1 & 0,9 \\
\hline $\mathrm{Yb}$ & 2,1 & 2,8 & 3,2 & 2,6 & 1,8 & 1,8 & 2,7 & 5,1 & 38,5 & 35,2 & 14,5 & 68,5 & 11,3 & 10,3 & 5,9 \\
\hline $\mathrm{Lu}$ & 0,2 & 0,4 & 0,4 & 0,3 & 0,2 & 0,2 & 0,4 & 0,5 & 5,1 & 4,7 & 1,8 & 9,0 & 1,1 & 1,4 & 0,9 \\
\hline$\Sigma$ REE & $3.205,8$ & $1.641,1$ & $1.890,21$ & $10.530,5$ & $1.956,0$ & $1.972,1$ & $2.969,6$ & $7.603,5$ & $34.136,3$ & $23.742,2$ & $15.259,23$ & $37.075,81$ & $10.998,5$ & $4.139,2$ & $2.905,6$ \\
\hline $\mathrm{Hf}$ & 5 & 2 & 8 & 8 & 11 & 8 & 6 & 14 & 25 & 45 & 45 & 22 & 36 & 36 & 38 \\
\hline $\mathrm{Ta}$ & 37 & 27 & 37 & 65 & 18 & 39 & 43 & 68 & 245 & 503 & 164 & 172 & 114 & 44 & 42 \\
\hline $\mathrm{Th}$ & 44 & 79 & 49 & 78 & 20 & 70 & 44 & 180 & 1406 & 1128 & 278 & 832 & 254 & 124 & 120 \\
\hline $\mathrm{U}$ & 6 & 59 & 13 & 11 & 7 & 9 & 10 & 49 & 729 & 478 & 95 & 67 & 46 & 18 & 17 \\
\hline
\end{tabular}

Rock types: 1 metasomatized olivine-rich bebedourite, 2 Ca-carbonatite, 3 metasomatized phoscorite, 4-5-7 Ca-carbonatite metasomatized perovskite bebedourite, 6-16 metasomatized pyroxene bebedourite, 8 metasomatized bebedourite with phoscorite cumulate, 9 to 12 bebedourite, 13-14 undifferentiated, $15 \mathrm{Mg}$-carbonatite metasomatized perovskite bebedourite. Analyses from Acme Analytical Laboratories. 
The alloterite horizon is characterized by absence of most soluble compounds such as $\mathrm{MgO}, \mathrm{CaO}$ and $\mathrm{K}_{2} \mathrm{O}$. The Lower Alloterite contains the highest levels of $\mathrm{TiO}_{2}$ and $\mathrm{Fe}_{2} \mathrm{O}_{3}$ in the whole weathering profile, due to the accumulation of residual anatase and abundant iron oxide/hydroxides. $\mathrm{P}_{2} \mathrm{O}_{5}$ is homogeneously distributed throughout this horizon, contained in Al-rich phosphates and monazite. The Lower Alloterite also contains the highest values of $\mathrm{Nb}_{2} \mathrm{O}_{5}$ as residual concentrations of pyrochlore from carbonatitic protoliths. $\mathrm{MnO}$, contained in oxides/hydroxides is abundant, reaching the highest values at the top of the lower alloterite horizon.

The transition from lower alloterite to upper alloterite is marked by an abrupt decrease in $\mathrm{Fe}_{2} \mathrm{O}_{3}$ and $\mathrm{SiO}_{2}$ values and gradual increase in $\mathrm{Al}_{2} \mathrm{O}_{3} . \mathrm{SiO}_{2}$ and $\mathrm{Al}_{2} \mathrm{O}_{3}$ show a mirrored behavior toward the top of the profile, reflecting the change from abundant kaolinite at the base to abundant gibbsite at the top of the Upper Alloterite. $\mathrm{TiO}_{2}$ values are minor and related to residual anatase. $\mathrm{REE}_{2} \mathrm{O}_{3}$ values increase in the Oxidized Isalterite and lower alloterite horizons, and gradually decrease to a minimum in the upper alloterite. Local peaks (>3.0\%wt.) inside the lower alloterite and Oxidized Isalterite are directly related to the presence of monazite pseudomorphs over carbonate.

\subsubsection{Trace Elements}

Normalized spidergrams (Figure 2.15) show that fresh metasomatized bebedourites are enriched in incompatible trace elements. Metasomatized fresh bebedourites with D4 magnesiocarbonatite are even more enriched and show pronounced negative anomalies in P. Normalized compositions of metasomatized phoscorites show a smooth pattern, enriched in $\mathrm{P}$ and $\mathrm{Sr}$. The isalterite saprolite pattern shows a progressive increase in REE, Th, $\mathrm{P}$ and Ti and negative anomalies for $\mathrm{K}, \mathrm{Sr}$ and $\mathrm{Rb}$, when compared to fresh bebedourites. On the other hand, the chemical signature of the entire isalteritic saprolite is similar to that of the carbonatite sample, and it is possible that this horizon derives from a carbonatite-dominated rock mixture or that it results from the systematic removal of more soluble elements, mostly $\mathrm{K}$, of a bebedourite-dominated rock. The lower alloterite shows the highest REE, Ti, Ba and $\mathrm{Nb}$, as expected from residual concentration of the relevant minerals as described above. The geochemical signature of the Lower Alloterite is similar to the isalteritic horizon. Trace 
element contents in the Upper alloterite are similar to the fresh rock, except for a minor increase in HREE. The geochemical pattern is also similar to the isalterite and lower alloterite horizons, indicating a progressive weathering from similar rocks. 

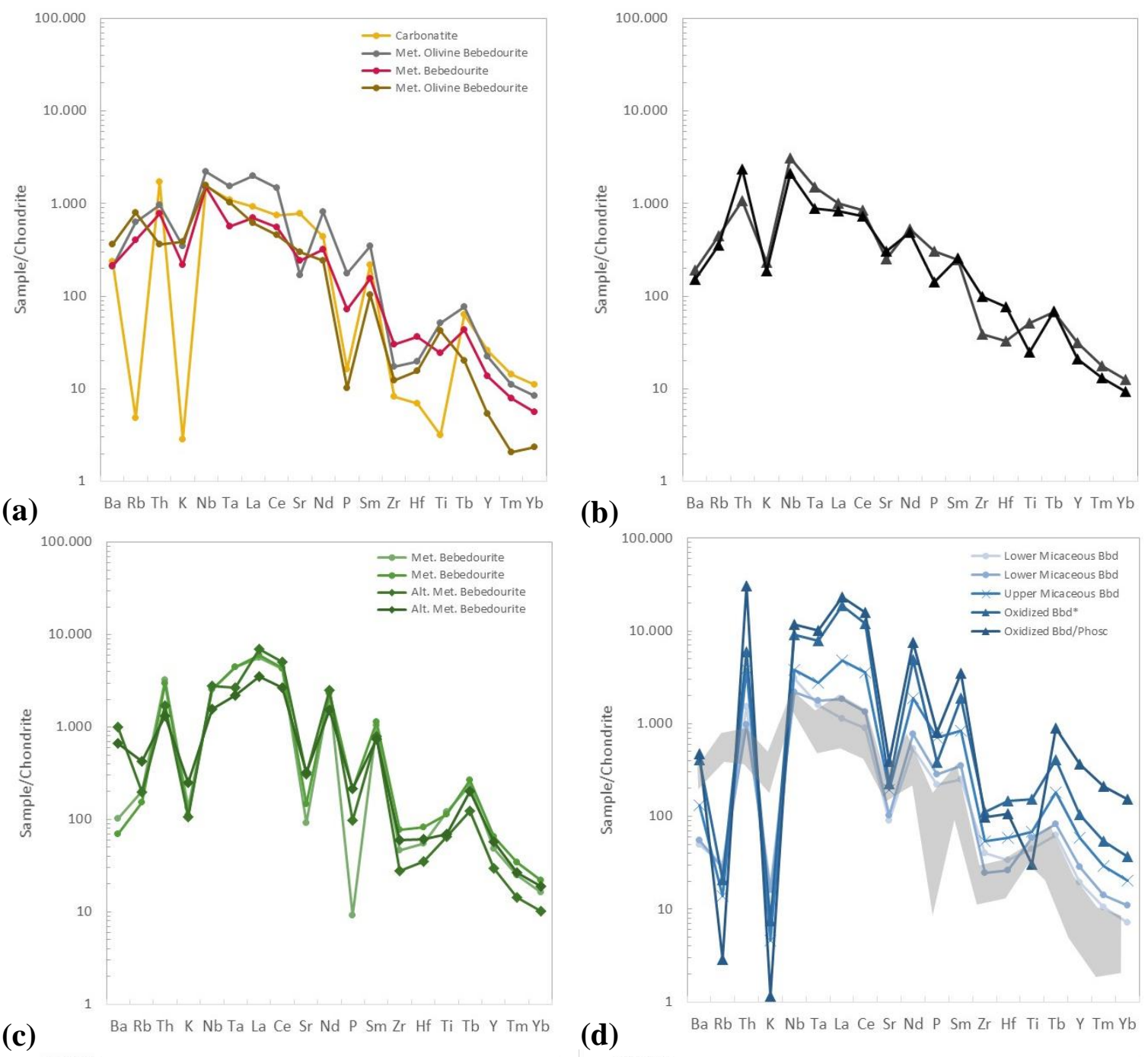

(b)
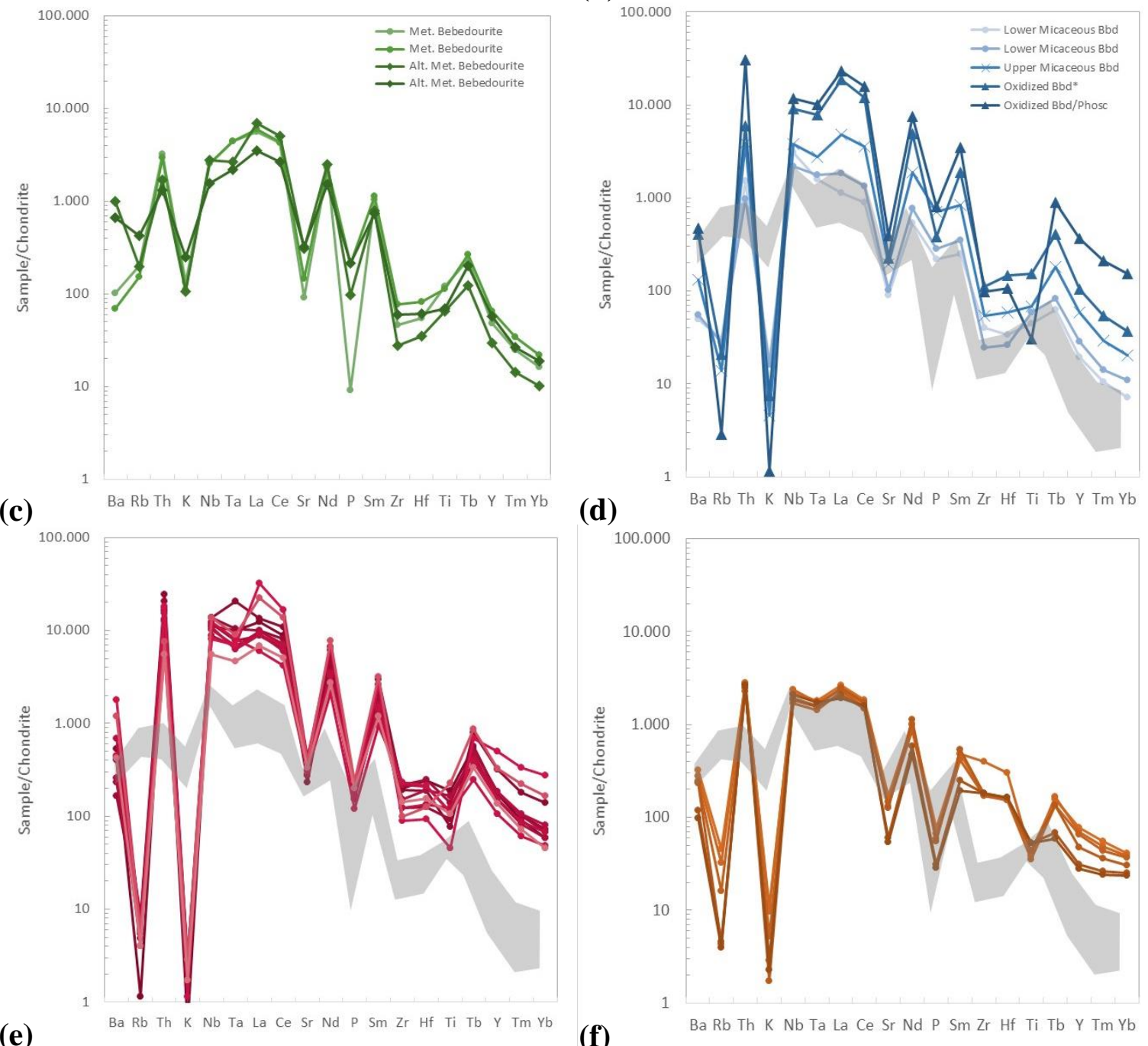

Figure 2.15: Chondrite-normalized (Thompson et al., 1984) trace-element diagrams for selected Salitre Complex weathering profile samples. Grey areas represent the average of the fresh bebedourite samples. (a) bebedourites metasomatized by $\mathrm{C} 3$ calciocarbonatites (b) phoscorites (c) bebedourites metasomatized by D4 magnesiocarbonatite (d) isalterite. (e) lower alloterite. (f) upper alloterite. Met = metasomatized; Bbd = bebedourite; $\mathrm{Phc}=$ phoscorite. 

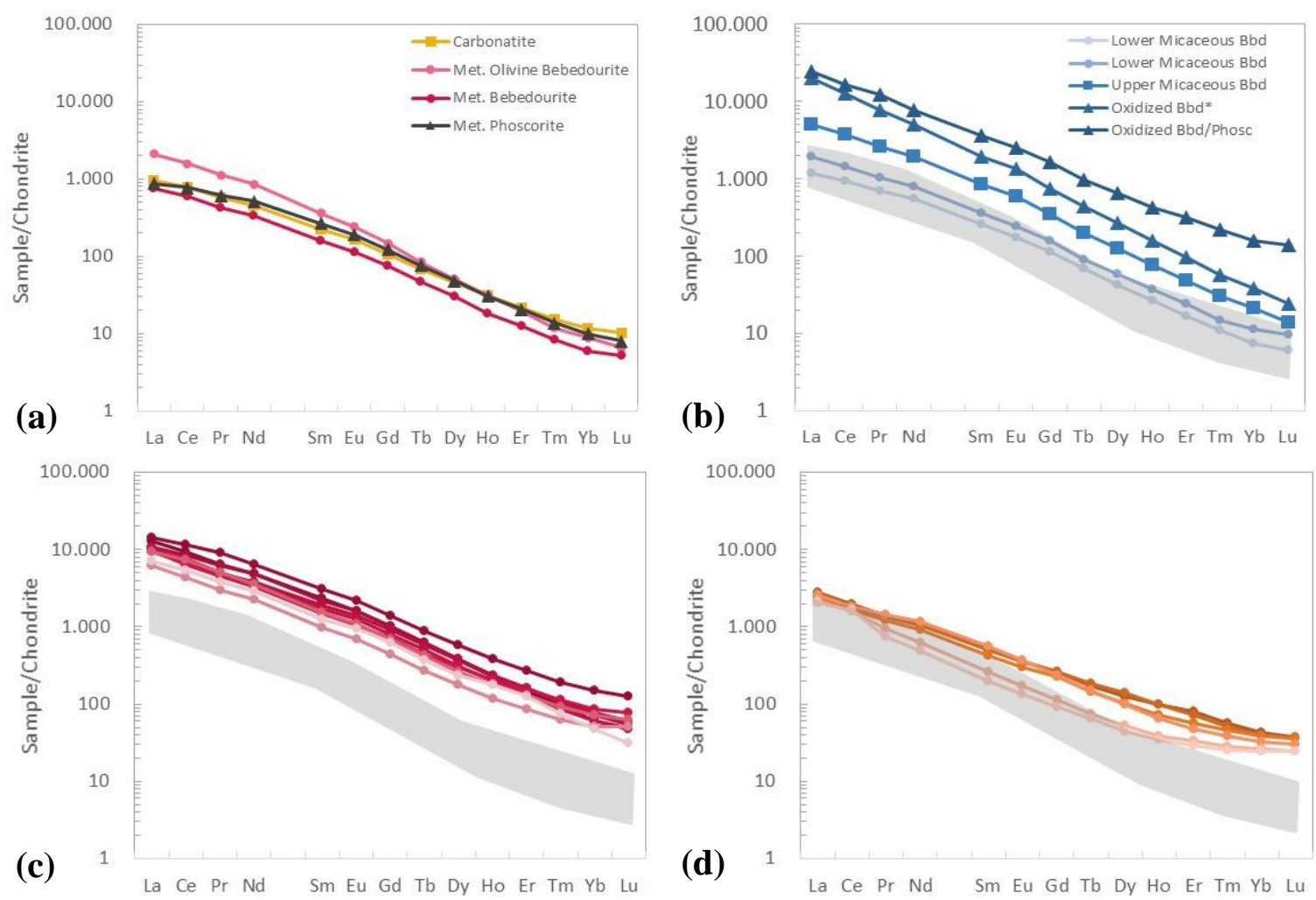

Figure 2.16: Chondrite-normalized (Boynton, 1984) REE patterns for selected Salitre Complex weathering profile samples. Grey areas represent the average of the bebedourite samples. (a) igneous paragenesis. (b) isalterite. (c) lower alloterite. $(\mathrm{d})$ upper alloterite. Met $=$ metasomatized; $\mathrm{Bbd}=$ bebedourite; $\mathrm{Phc}=$ phoscorite. 


\subsubsection{Rare Earth Elements}

Rare earth contents of B1a metasomatized fresh bebedourites without anatase are in a restricted range, from $0,08 \%$ w.t. to $0,16 \%$ wt. total REE, close to the values of the $\mathrm{C} 3$ carbonatite $(0,14 \%$ wt.). Bebedourites associated with D4 carbonatite and metasomatic anatase are enriched in REE when compared to other metasomatized bebedourites. Chondrite-normalized rare-earth patterns (Figure 2.16) of the fresh rock display approximately the same grades of LREE/HREE fractionation, except for the carbonatite. The latter has a $\mathrm{La} / \mathrm{Lu}$ ratio of 90, against an average value of 190 in bebedourites, differently from the observations by Oliveira and Ibernon, (1998) for Catalão I. Chondrite-normalized REE distribution patterns for bebedourite-related rocks and alterites are given in Figure 2.16. They show a progressive and homogeneous upward accumulation of REE, from fresh rock to the lower alloterite horizon. Only the upper alloterite horizon is depleted in REE. The normalized REE pattern in the weathered profile tends to be parallel to that of the fresh rock, with higher grades of REE. No individual REE anomalies, such as $\mathrm{Eu}$ or $\mathrm{Ce}$, were found. REE patterns for the analyzed carbonatite and phoscorite samples are similar to those of the the metasomatized B1a-type bebedourites. Bebedourites metasomatized by the D4 magnesiocarbonatite are richer in LREE than bebedourites metasomatized by calciocarbonatites.

\subsection{Discussion and Conclusion}

The weathering profile developed over Salitre bebedourites presents several similarities with other studied weathering profiles over alkaline-carbonatite occurrences (Morteani and Preinfalk, 1996; Oliveira and Imbernon, 1998; Brod et al., 2001; Toledo and Pereira; 2003; Wilson, 2004; Freyssinet, 2005, Ribeiro, 2008; Azzone and Rubertti, 2010; Barbosa, 2012). Mineral distribution and relative abundance is displayed in Figure 2.17. 


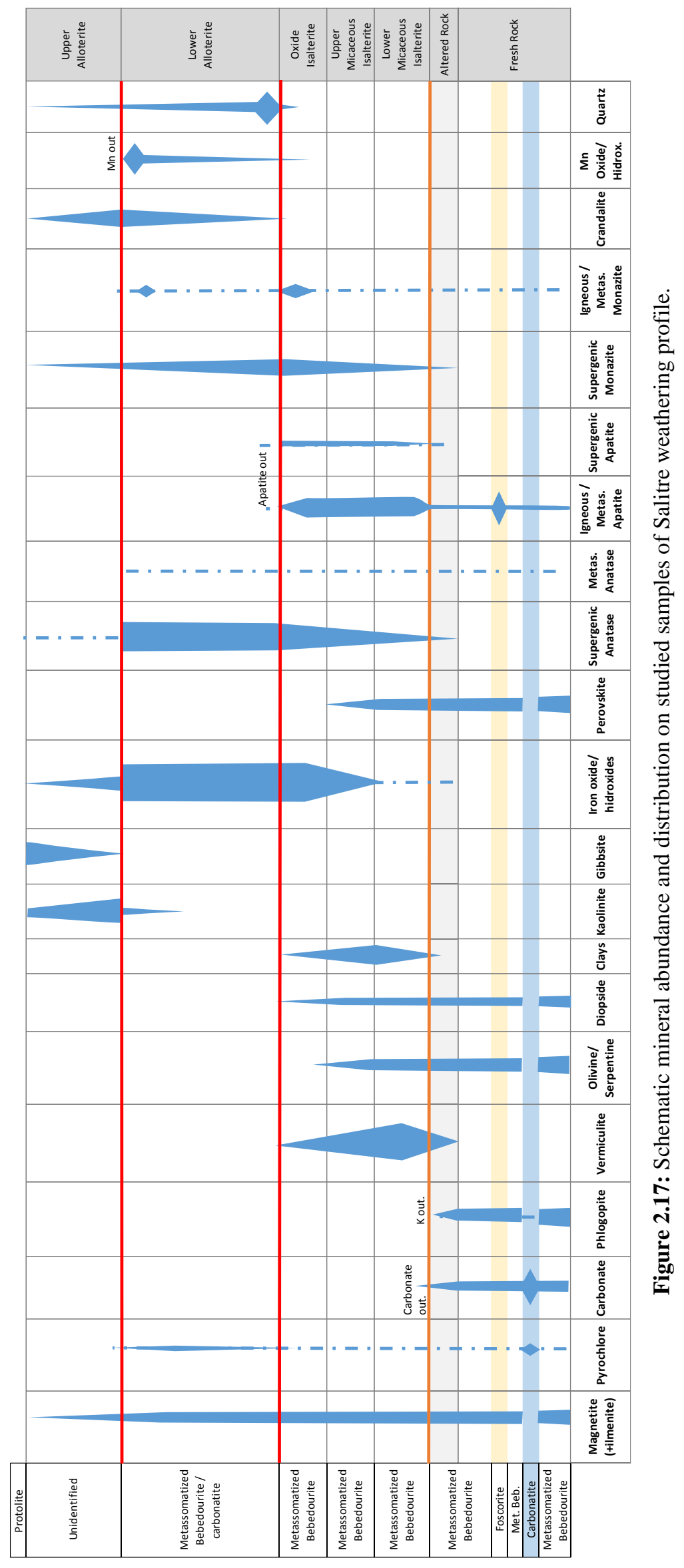


Olivine is strongly serpentinized and readily weathered to interstratified clay minerals, often impregnated with iron oxides/hydroxides, at the isalterite level. The presence of olivine and its alteration products are limited to the B1a-type bebedourite. Diopside is more resistant to weathering than olivine, with commonly preserved residual fragments surrounded by homogeneous masses of Fe-rich interstratified clays more or less impregnated with iron oxide/hydroxides. We interpret the occurrences of this texture in the isalterite as indicative of derivation from a B1b-type protolith. Phlogopite weathering begins at the altered rock horizon, with the removal of interlayer $\mathrm{K}^{+}$. The resulting material is initially composed of $\mathrm{Mg}$-rich vermiculite interstratified with phlogopite, grading to $\mathrm{Mg}$ - and Fe-rich smectites in more evolved parts of the profile, mainly the lower and upper micaceous isalterite. Azzone et al. (2010) observed a similar mineralogy and distribution for the Catalão I deposit.

K-depleted phlogopite alteromorphs, mostly Mg-vermiculite, preserve the morphology of large phlogopite crystals in the lower micaceous horizon. This feature, along with the preservation of minerals, such as perovskite, magnetite and apatite, allows the recognition of the original texture and composition of the protolith at a mesoscopic scale. Deformed vermiculite sheets impregnated with iron oxide/hydroxides are a common feature of upper micaceous isalterite. The vermiculite is gradually replaced by iron oxides/hydroxides in the Oxidized Isalterite.

Apatite is a stable phase throughout the isalterite profile, reaching economic concentrations in this horizon. Most of the apatite present in the studied profile is of igneous origin. Igneous apatite from bebedourites and phoscorites are rich in fluorine and show traces of Sr. Sr was observed in apatite from Catalão I (Lenharo, 1994; Pereira, 1995) also in association with fluorine. Apatites from carbonatitic origin shows highest levels of REE, Sr and $\mathrm{Na}$. Secondary apatite is also fluorapatite with no detectable trace elements, but further WDS analyses are needed to confirm the absence of $\mathrm{Sr}$ and $\mathrm{Na}$.

Crandallite is abundant at the lower alloterite level, forming solid solutions toward gorceixite (Ba) and goyazite ( $\mathrm{Sr}$ ). This is consistent with a Ca depletion observed in the aluminous phosphates from more weathered parts of the profile. $\mathrm{SiO}_{2}$ values increase in the Salitre crandallite-group minerals with weathering evolution. 
Anatase is present through the entire weathering profile, reaching the highest concentrations in the Lower Alloterite (up to $30 \mathrm{wt}$. \%). Since anatase is a direct product of perovskite weathering, it is assumed that this concentration peak is a result of residual accumulation. It is also assumed that anatase abundance indicates that the protolith had a strong bebedouritic component. Perovskite weathering to anatase is gradual and progresses from the Lower Micaceous Isalterite to the top of the profile. At the Lower Alloterite horizon, all perovskite is weathered to anatase, forming holo-alteromorphs. This anatase is texturally complex, microcrystalline and extremely porous. It often contains newly-formed needle-like monazite crystals. This close association of anatase and monazite suggests that the REE originally contained in perovskite (average of $1.5 \mathrm{wt} . \% \mathrm{REE}_{2} \mathrm{O}_{3}$ ), and not stable in the anatase structure, are complexed with available $\mathrm{P}_{2} \mathrm{O}_{5}$ from apatite dissolution to form monazite.

Metasomatic anatase is often associated with D4-type, magnesian, Sr- and Ba-rich carbonatite veins. The Ba-bearing phase in these rocks is barite, indicating a more oxydizing condition. In our samples, the formation of metasomatic anatase seems to be restricted to the interaction between the perovskite-rich B1a bebedourite and the D4-type carbonatite. This interpretation is consistent with the fact that perovskite from bebedourites intruded by $\mathrm{C} 3$ calciocarbonatite is intact.

The highest $\mathrm{REE}_{2} \mathrm{O}_{3}$ grades in the Salitre alteration profile are related to monazite pseudomorphs after carbonate. While the monazite derived from perovskite/anatase alteration is often small and encapsulated in the Ti phase, monazite pseudomorphs occur as larger dispersed crystals $(>100 \mu \mathrm{m})$. The rombohedral morphology of the latter and a partially replaced calcite grain found in the fresh rock support the interpretation of the origin of this monazite from the pseudomorphic replacement of carbonates. Kasioptas et al. (2010) experimentally synthesized polycrystalline phosphates of the apatite group after calcium carbonates at low temperatures (up to $300^{\circ} \mathrm{C}$ ). The final polycrystalline apatite kept the morphology of the original specimen, with increased porosity. Their study and the observations in our work suggest that the monazite pseudomorphs are of hydrothermal origin and not supergenic, but further studies are needed to confirm this hypothesis. All analyzed monazite shows low $\mathrm{Th}_{2} \mathrm{O}_{5}$ grades ( $<2 \mathrm{wt}$. \%). Low Th grades are described in monazite from other APIP carbonatites (Toledo, 2004) and are atypical. Monazite from Kola carbonatites (Chakhmouradian and Mitchell, 1998) and Argentina (Del Blanco et al, 1998) shows $\mathrm{Th}_{2} \mathrm{O}_{5}$ 
values higher than 5 wt. \% (Toledo, 2004). The size, occurrence and low Th contents make this type of monazite an important candidate for future economic exploitation.

The origin and association of the upper alloterite horizon is uncertain. It contains large amounts of kaolinite at the base, but this gradually gives place to gibbsite as the main constituent toward the surface. The presence of kaolinite and gibbsite right above the Si- and Al-depleted lower alloterite horizon strongly suggests that the upper alloterite is allochthonous. The absence of residual accumulation of more stable, weathering-resistant minerals such as anatase and magnetite, which are abundant in lower horizons, is another strong evidence of the allochthonous origin of this material. However, the chemical signature is similar to the fresh rock and other alterites, except for a minor enrichment of HREE, suggesting that the upper alloterite derives from similar alkaline rocks and carbonatites and that, if it is allochthonous, this material originated within the intrusion area.

\subsection{Acknowledgements}

The authors thank Vale Exploration and Vale Fertilizers for access and permission to sample Salitre I drill cores and to their technical staff for early discussions. Vale Exploration and the Centro de Desenvolvimento Mineral-CDM are specially thanked for the financial support and access to sample preparation, SEM and DRX facilities. The University of Brasilia is thanked for microprobe analyses and LabMic at the University of Goiás for additional SEM and EDS analysis.

\subsection{References}

Alcover Neto, A. and de Toledo, M.C.M. (1993) Evolução supérgena do carbonatito de Juquiá (SP). Revista do Instituto de Geologia, São Paulo No 14(1): 31-43.

Altschuler, Z. S. 1973. The weathering of phosphate deposits. Geochemical and environmental aspects. Griffith, E.J., Beeton, A., Spencer, J. M., Mitchell, D. T., editors. Wiley, New York, USA. 33-96.

Angélica, R.S. and da Costa, M.L. (1993) Geochemistry of rare- earth elements in surface lateritic rocks and soils from the Maicuru complex, Pará , Brazil. Journal of Geologic Exploration No 47: 165-182.

Araújo, D.P., 1996. Metassomatismo no complexo carbonatítico Catalão-I: implicações para a composição do magma carbonatítico e para o metasomatismo carbonatítico no manto superior. Msc. Thesis, University of Brasília, Brazil. 
Azzone, R. G., Ruberti, E. 2010. Evolução composicional dos filossilicatos no perfil intempérico do Complexo Ultramáfico Alcalino-carbonatítico de Catalão I (GO). Revista do Instituto de Geociências - USP 10: 2343.

Barbosa E.S.R., 2009. Mineralogia e Petrologia do Complexo Carbonatítico-Foscorítico de Salitre, MG. IG/UnB, 434pp.

Barbosa, E. S. R., Brod, J. A., Junqueira-Brod, T. C., Dantas, E. L., Cordeiro, P. F. O., and Gomide, C. S., 2012, Bebedourite from its type area (Salitre I complex): A key petrogenetic series in the Late-Cretaceous Alto Paranaiba kamafugite-carbonatite-phoscorite association, Central Brazil. Lithos 144: 56-72.

Bayliss, P., Kolitsch, U., Nickel, E. H., and Pring, A., 2010. Alunite supergourp: recommended nomenclature. Mineralogical Magazine 75(5): 919-927.

Berbert, C.O., 1984. Carbonatites and associated mineral deposits in Brazil. Geol. Survey of Japan. Report 263: $269 \pm 290$.

Bizzi, L.A., De Wit, M.J., Smith, C.B., McDonald, I., Armstrong, R.A., 1995. Heterogeneous enriched mantle materials and Dupal-type magmatism along the SW margin of the São Francisco Craton, Brazil. Journal of Geodynamics 20: 469-491.

Blanchard, F. N. 1974. Thermal analysis of crandallite. Quarterly Journal of the Florida Academy of Sciences 34(1): 1-9.

Boulingui, B., 1997, Mineralogie et géochimie du gisement résiduel de phosphore et de niobium de Mabounié (Moyen-Ogooue, Gabon): Unpublished Ph.D. thesis, University Nancy, France, 150 pp.

Brod, J. A., 1999. Petrology and geochemistry of the Tapira alkaline complex, Minas Gerais State, Brazil. PhD thesis, University of Durham, UK.

Brod, J. A., Gibson, S. A., Thompson, R. N. Junqueira-Brod, T. C. Seer, H. J., Moraes, L. C., Boaventura, G. R. 2000. Kamafugite affinity of the Tapira alkaline-carbonatite complex (Minas Gerais, Brazil). Revista Brasileira de Geociências 30: 404-408.

Brod, J.A., Gaspar, J.C., Araújo, D.P., Gibson, S.A., Thompson, R.N., Junqueira-Brod, T.C., 2001. Phlogopite and tetra-ferriphlogopite from Brazilian carbonatite complexes: petrogenetic constraints and implications for mineral-chemistry systematics. Journal of Asian Earth Sciences 19: 265-296.

Brod, J.A., Ribeiro, C.C., Gaspar, J.C., Junqueira-Brod, T.C., Barbosa, E.S.R., Riffel, B.F., Silva, J.F., Chaban, N., Ferrari, A.J.D., 2004. Guia de excursão 1: Geologia e Mineralizações dos Complexos AlcalinoCarbonatíticos da Província Ígnea do Alto Paranaíba. $42^{\circ}$ Congresso Brasileiro de Geologia. Araxá, Brasil.

Brod J.A., Gaspar J. C., Diniz-Pinto H. S., Junqueira-Brod T.C., 2005. Spinel chemistry and petrogenetic processes in the Tapira alkaline-carbonatite complex, Minas Gerais, Brazil. Revista Brasileira de Geociências 35 (1): 23-32.

Carlson, R.W., Esperança, S., Svisero, D.P., 1996. Chemical and Os isotopic study of Cretaceous potassic rocks from Southern Brazil. Contributions to Mineralogy and Petrology 125: 393-405.

Carlson, R.W., Araújo, A.L.N., Junqueira-Brod, T.C., Gaspar, J.C., Brod, J.A., Petrinovic, I.A., Holanda, M.H.B.M., Pimentel, M.M., Sichel, S., 2007. Chemical and isotopic relationships between peridotite xenoliths and mafic-ultrapotassic rocks from Southern Brazil. Chemical Geology 242: 415-434. 
Chakhmouradian, A.R. and Mitchell, R.H. 1997. Compositional variation of perovskite-group minerals from the carbonatite complexes of the Kola Alkaline Province,, Russia. Canaddian Mineralogist 35: 1293 - 310.

Chatelin, Y. 1974. Les soils ferrallitiques. 111. L'alteration. Office Rech. Sci. Techn. Outre-Mer (ORSTOM, Paris), Initiations, Doe. Techn 24: 144 p.

Comin-Chiaramonti, P., Gomes, C.B. (Editors), 1996. Alkaline magmatism in Central-Eastern Paraguay. In: Relationships with coeval magmatism in Brazil. EDUSP/FAPESP, São Paulo, Brazil.

Comin-Chiaramonti, P., Cundari, A., Piccirillo, E.M., Gomes, C.B., Castorina, F., Censi, P., DeMin, A., Marzoli, A., Speziale, S., Velazquez, V.F., 1997. Potassic and sodic igneous rocks from eastern Paraguay: Their origin from the lithospheric mantle and genetic relationships with the associated Paraná flood tholeiites. Journal of Petrology 38: 495-528.

Comin-Chiaramonti, P., Gomes, C. B. (Editors), 2005. Mesozoic to Cenozoic alkaline magmatism in the Brazilian Platform. EDUSP/FAPESP, São Paulo, Brazil, 751 pp.

Cook, P.J., 1984, Spatial and temporal controls on the formation of phosphates deposits-a review, in Nriagu, J.O., and Moore, P.B., eds., Phosphates minerals: Berlin, Springer-Verlag. 242-274.

Cordeiro, P. F. O., Brod, J. A., Dantas, E. L., and Barbosa, E. S. R., 2010, Mineral chemistry, isotope geochemistry and petrogenesis of niobium-rich rocks from the Catalão I carbonatite-phoscorite complex, Central Brazil: Lithos 118: 223-237.

Cordeiro, P. F. O., Brod, J. A., Palmieri, M., Oliveira, C. G., Barbosa, E. S. R., Santos, R. V., Gaspar, J. C., and Assis, L. C., 2011, The Catalão I niobium deposit, central Brazil: resources, geology and pyrochlore chemistry: Ore Geology Reviews 41: 112-121.

Cordeiro, P.F.O., Brod, J.A., Santos, R.V., 2009. Stable (C,O) and radiogenic (Sr;Nd) isotopes of carbonates as indicators of magmatic and post-magmatic processes of phoscorite-series rocks and carbonatites from Catalao I, central Brazil. Contributions to mineralogy and petrology 161: 454-464.

Costa, G.V., 2008. Química mineral e geotermobarometria de xenólitos mantélicos do kimberlito Canastra 01. Msc. Thesis, University of Brasília, Brazil.

Danni, J.C.M., Baecker, M.L., Ribeiro, C.C., 1991. The geology of the Catalão I carbonatite complex. 5th International Kimberlite Conference. CPRM, Araxá, Brazil, 25-30.

Deer, W.A., Howie, R.A., Zussman, J., 1992. An introduction to rock-forming minerals. Longman, Essex, 696 pp.

Del Blanco, M., Costas Ulbrich, M., Echeveste, H. \& Vlach, S.R.F. 1998. Las monacitas-(Nd) con samario de los diques carbonatiticos del sector nororiental de la Sierra de Cobres, Salta, Argentina. In: Reunion de Mineralogia y metalogenia 4, Bahia Blanca, Argentina. 63-69.

Delvigne, J. E. 1998. Atlas of Micromofphology of Mineral Alteration and Weathering. The Canadian Mineralogis Special Publication 3. 494 pp.

Fleischer M., Rosenblum S., Woodruff M. 1990. The distribution of lanthanides and ytrium in the minerals of the monazite family. U.S. Geol. Survey. Open-File Repport 91-580, 125pp.

Fontana, J., 2006. Phoscorite-carbonatite pipe complexes - a promising new Platinum Group Element target in Brazil. Platinum Metals Review 50(3): 134-142. 
Freyssinet. P. Hp., Butt, C. R. M., Morris, R. C. 2005. Ore forming processes related to lateritic weathering. Economic Geology 100th Anniversary Volume. 681-722.

Gaspar J. C., Wyllie P. J., 1983. Ilmenite (high Mg,Mn,Nb) in the carbonatites from the Jacupiranga complex, Brazil. American Mineralogist 68: 960-971.

Gibson, S.A., Thompson, R.N., Leonardos, O.H., Dickin, A.P., Mitchell, J.G., 1995a. The Late Cretaceous impact of the Trindade mantle plume - evidence from large-volume, mafic, potassic magmatism in SE Brazil. Journal of Petrology 36: 189-229.

Gibson, S.A., Thompson, R.N., Dickin, A.P., Leonardos, O.H., 1995b. High-Ti and low-Ti mafic potassic magmas: Key to plume-lithosphere interactions and continental flood-basalt genesis. Earth and Planetary Science Letters 136: 149-165.

Gibson, S.A., Thompson, R.N., Weska, R.K., Dickin, A.P., Leonardos, O.H., 1997. Late Cretaceous rift-related upwelling and melting of the Trindade starting mantle plume head beneath western Brazil. Contributions to Mineralogy and Petrology 126: 303-314.

Girard, J. P., Flicoteaux, R., Walter, A. V., Savin, S., Nahon, D. 1993. Oxygen and carbon isotope composition of structural carbonate in weathering apatites from laterites, Southern Brazil and western Senegal. Applied Geochemistry 8: 617-632.

Gomes, C.B., Ruberti, E., Morbidelli, L., 1990. Carbonatite complexes from Brazil: a review. Journal of South American Earth Sciences 3: 51-63.

Gonzaga, G.M., Tompkins, L.A., 1991. Geologia do diamante. In: Principais depósitos minerais do Brasil. Brasília: DNPM/CPRM 4 $4^{\mathrm{a}}, 42-58$.

Grasso C.B. 2010. Petrologia do Complexo Alcalino- Carbonatítico de Serra Negra, MG. MSc. Thesis, University of Brasilia, 209 pp.

Gusev, G. M., ZANIN, Y. U. N., Krivolutskaya, L. M., Lemina, N. M., Yusupov, T. S. 1976.Transformation of apatite during weathering and leaching. Doklady Akad. Nauk SSSR 229: 146-148.

Haggerty, S.E., Mariano, A.N., 1983. Strontian-loparite and strontio-chevkinite: two new minerals in reomorphic fenites from the Paraná Basin carbonatites, South America. Contributions to Mineralogy and Petrology 84: 365-381.

Herz, N., 1977. Timing of spreading in the South Atlantic: information from Brazilian alkalic rocks. Geological Society of America Bulletin 88: 101-112.

Hogarth, D.D., Hartree, J.L., Solberg, T.N., 1985. Rare-element minerals in four carbonatites near Gatineau, Quebec. American Mineralogist 70: 1135-1142.

Hogarth, D. D., 1989. Pyrochlore, apatite and amphibole: distinctive minerals in carbonatite. In K. Bell (Ed.) Carbonatites: genesis and evolution. London, Unwin Hyman, 105-148.

Junqueira-Brod, T.C., Brod, J.A., Gibson, S.A., Thompson, R.N., 2000. Mineral chemistry of kamafugites and related rocks from Águas Emendadas region, Goiás state. Revista Brasileira de Geociências 30: $403-407$.

Junqueira-Brod, T.C., Roig, H.L., Gaspar, J.C., Brod, J.A., Meneses, P.R., 2002. A Província Alcalina de Goiás e a extensão de seu vulcanismo kamafugítico. Revista Brasileira de Geociências 32: 559-566.

Junqueira-Brod, T.C., Brod, J.A., Gaspar, J.C., Jost, H., 2004. Kamafugitic diatremes: facies characterisation and genesis - examples from the Goiás Alkaline Province, Brazil. Lithos 76: 261-282. 
Junqueira-Brod, T.C., Gaspar, J.C., Brod, J.A., Kafino, C.V., 2005a. Kamafugitic diatremes: their textures and field relationships with examples from the Goiás Alkaline Province, Brazil. Journal of South American Earth Sciences 18: 337-353.

Junqueira-Brod, T.C., Gaspar, J.C., Brod, J.A., Jost, H., Barbosa, E.S.R., Kafino, C.V., 2005b. Emplacement of Kamafugite Lavas from the Goiás Alkaline Province, Brazil: Constraints from whole-rock simulations. Journal of South American Earth Sciences 18: 323-335. Kamitani, M. and Hirano, H. (1987) AraxaÂ carbonatite deposit and its lateritization. Geol. Survey of Japan. Report 263, 56-73.

Karchevsky, P.I., Moutte, J., 2004. The phoscorite-carbonatite complex of Vuoriyarvi, northern Karelia. In: Phoscorites and Carbonatites from Mantle to Mine: the Key Example of the Kola Alkaline Province (F. Wall and A.N. Zaitsev, editors) Mineralogical Society Series, 163-169 pp.

Kasioptas, A., Geisler, T., Perdikouri, C., Trepmann, C., Gussone, N. and Putniss, A. 2011. Polycrystalline apatite synthesized by hydrothermal replacement of calcium carbonates. Geochimica et Cosmochimica Acta $75:$ 3486-3500.

Kasputin, Y.L., 1980. Mineralogy of carbonatites. Amerind Publishing, New Delhi.

Krasnova, N.I., Petrov, T.G., Balaganskaya, E.G., Garcia, D., Moutte, D., Zaitsev, A.N., Wall, F., 2004. Introduction to phoscorites: occurrence, composition, nomenclature and petrogenesis. In: F. Wall, A.N. Zaitsev (Editors). Phoscorites and Carbonatites from Mantle to Mine: the Key Example of the Kola Alkaline Province. Mineralogical Society, London, 45-79 pp.

Lee, M.J., Garcia, D., Moutte, J., Lee, J.I., 2003. Phlogopite and tetra-ferriphlogopite from phoscorite and carbonatite associations in the Sokli massif, Northern Finland. Geosciences Journal 7: 9-20.

Lenharo, S.L.R. (1994): Caracterização mineralógica/tecnológica das apatitas de alguns depósitos brasileiros de fosfato. M.Sc. thesis, Univ. de São Paulo, São Paulo, Brazil.

Lloyd, F.E., Bailey, D.K., 1991. Complex mineral textures in bebedourite: possible links with alkali clinopyroxenite xenoliths and kamafugitic volcanism. 5th International Kimberlite Conference. CPRM, Araxá, Brazil, 263-269 pp.

Lottermoser B.G. 1990. Rare-Earth element mineralization within the Mt. Weld carbonatite laterite, Western Australia. Lithos 24:151-67.

Lucas, J., Flicoteaux, R. 1984. Weathering of phosphate mineraIs. Phosphate mineraIs: J.B. Nriagu e P.B. Moore (eds.), Berlin-Heideberg-New York0Tokyo. Springer-Verlag, 292-317 pp.

Mariano A.N., Marchetto M. 1991. Serra Negra and Salitre carbonatite alkaline igneous complex. In O.H. Leonardos, H.O.A. Meyer, J.C. Gaspar (Eds.), 5th IKC. (Field Guide Book). Araxá, CPRM, Sp. Publ. 3/91. 75-79.

McArthur, J. M. 1985. Francolite geochemistry compositional controls during formation, diagenesis metamorphism and weathering. Geochimica et Cosmochimica Acta 49: 23-45.

Miler, M., Mirtic, B. 2013. Accuracy and precision of EDS analysis for identification of metal-bearing minerals in polished and rough particle samples. Geologija 56(1): 005-018.

Morbidelli, L., Gomes, C.B., Beccaluva, L., Brotzu, P., Conte, A.M., Ruberti, E., Traversa, G., 1995 a. Mineralogical, petrological and geochemical aspects of alkaline and alkaline-carbonatite associations from Brazil. Earth-Science Reviews 39: 135-168. 
Morbidelli, L., Beccaluva, L., Brotzu, P., Conte, A.M., Garbarino, C., Gomes, C.B., Grossi-Sad, J.H., Riffel, B.F., Ruberti, E., Traversa, G., 1995b. Aspectos mineralógicos e petrográficos de rochas ultramáficas e carbonatitos do complexo alcalino de Salitre, GO. $5^{\circ}$ Congresso Brasileiro de Geoquímica. SBGq, Niteroi, Brazil (CD-ROM).

Morbidelli, L., Gomes, C.B., Beccaluva, L., Brotzu, P., Garbarino, C., Riffel, B.F., Ruberti, E., Traversa, G., 1997. Parental magma characterization of Salitre cumulate rocks (Alto Paranaíba Alkaline Province, Brazil) as inferred from mineralogical, petrographic, and geochemical data. International Geology Review 39: $723-743$.

Mordberg, L. E., Stanley, C. J., Germann K. 2000. Rare earth element anomalies in crandallite group minerals from the Schugorsk bauxite deposit, Timan, Russia Eur J Mineral, 12: 1229-1243.

Morteani, G. \& Preinfalk, C. 1996. REE distribution and REE carriers in laterites formed on the alkaline complexes of Araxá and Catalão (Brasil). A.P. Jones, F. Wall, C.T. Williams (eds.) Rare Earth minerals, The Mineralogical Series. 7, The Mineralogical Society, London, 227-256.

Neumann, R., Lapido-Loureiro, E. V. 1993. Caracterização mineralógica e litogeouqímica dos depósitos de elementos de terras raras do córrego do Garimpo (Catalão), Morro do Ferro (Poços de Caldas, MG) e Barreiro-Araférticl (Araxá, MG). 4o Congresso Brasileiro de Geoquímica, Brasília. 189-192.

Neumann, R. 1994. Origem do minério de terras raras do córrego do Garimpo, Catalão, GO. 38o Congresso Brasileiro de Geologia, Camboriú 2: 182-183.

Neumann R. 1999. Caracterização tecnológica dos potenciais minérios de terras-raras de Catalão I, GO. PhD thesis, Instituto de Geociências, Universidade de São Paulo, 204pp.

Ni, Y., Hughes, J.M., Mariano, A.N. 1995. Crystal chemistry of the monazite and xenotime structures. American Mineralogist 80:21-26.

Oliveira, S. M. B, Imbernon, R. A. L. 1998. Weathering alteration and related REE concentration in the Catalão I carbonatite complex, central Brazil, Journal of South American Earth Sciences. Vol 11 No 4: 379-388.

Palmieri, M. 2011. Modelo geológico e avaliação de recursos minerais do depósito de Nióbio Morro do Padre, Complexo alcalino-carbonatítico Catalão II, GO. MSc. Thesis, University of Brasilia. 130pp.

Pereira, V. P. 1995. Alteração no Maciço Alcalino-carbonatítico de Catalão I (GO), Brasil: vvolução mineralógica. Instituto de Geociências, PhD thesis, Universidade Federal do Rio Grande do Sul, Brazil.

Prins, P. 1973. Apatite from african carbonatites. Lithos 6: 133-144.

Reedman, J. H.. 1984. Resources of phosphate, niobium, iron, and other elements in residual soils over the Sukulu carbonatite complex, Southern Uganda. Economic Geology 79: 716-724.

Ribeiro, C.C., Brod, J.A., Junqueira-Brod, T.C., Gaspar, J.C., Petrinovic, I.A., 2005. Mineralogical and field aspects of magma-fragmentation deposits in a carbonate-phosphate magma chamber: evidence from the Catalão I Complex, Brazil. Journal of South American Earth Sciences 18: 355-369.

Ribeiro, C.C., 2008. Geologia, geometalurgia, controles e gênese dos depósitos de fósforo, terras raras e titânio do Complexo Carbonatítico de Catalão I, GO. Tese de Doutoramento, Universidade de Brasília, Brasil.

Ribeiro, C. C., Brod, J. J., Junqueira-Brod, T. C., Gaspar, J. C., Palmieri, M., Cordeiro, P. F. de O., Torres, M. G., Grasso, C. B., Barbosa, E. S. R., Barbosa, P.A.R., Ferrari, A. J. D., Gomide, C. S. 2014. Potencial e controles metalogenéticos de ETR, Ti e Nb em províncias alcalino-carbonatíticas brasileiras. In: Maria da 
Glória da Silva; Manoel Barreto da Rocha Neto; Hardy Jost; Raul Minas Kuyumjian (Org.). Metalogênese das províncias tectônicas brasileiras. Belo Horizonte: CPRM. 559-589.

Riccomini, C., Velázquez, V. F., Gomes, C. de B. 2005. Tectonic controls of the Mesozoic and Cenozoic alkaline magmatism in central-southeastern Brazilian Platform. In: Celso de Barros Gomes; Piero CominChiaramonti (Org.). Mesozoic to Cenozoic alkaline magmatism in the Brazilian Platform. São Paulo: EDUSP-FAPESP. 31-55.

Seer, H.J., Moraes, L.C., 1988. Estudo petrográfico das rochas ígneas alcalinas da região de Lagoa Formosa, MG. Revista Brasileira de Geociências 18: 134-140.

Seer, H.J., Moraes, L.C.M., Fogaça A.C.C., 1989. Roteiro geológico para a região de Lagoa Formosa-ChumboCarmo do Paranaíba, MG. Sociedade Brasileira de Geologia, Belo Horizonte, Brazil, 58pp.

Sgarbi, P.B.A., Valença, J.G., 1993. Kalsilite in Brazilian kamafugitic rocks. Mineralogical Magazine 57: 165171.

Sgarbi, P.B.A., Valença J.G., 1994. Mineral and rock chemistry of the Mata da Corda kamafugitic rocks (MG State, Brazil). International Symposium on the Physics and Chemistry of the Upper Mantle. CPRM/FAPESP, São Paulo, Brazil.

Sgarbi, P.B.A., Gaspar, J.C., 1995. Perovskites from the Mata da Corda kamafugites, MG, Brazil. 6th International Kimberlite Conference. Novosibirsk, Russia, 498-499.

Sgarbi, P.B.A., Heanman, L.M., Gaspar, J.C., 2004. U-Pb perovskite ages for brazilian kamafugitic rocks: further support for a temporal link to a mantle plume hotspot track. Journal of South American Earth Sciences 16: 715-724.

Sommerauer, J., Katz-Lehnert, K. 1985. A new partial substitution mechanism of $\mathrm{CO}_{3}{ }^{2-} / \mathrm{CO}_{3} \mathrm{OH}^{3-}$ and $\mathrm{SiO}_{4}{ }^{4-}$ for the $\mathrm{PO}_{4}{ }^{3-}$ group in hydroxyapatite from the Kaiserstuhl alkaline complex (SW-Germany). Contributions to Mineralogy and Petrology 91: 360-368.

Sonoki, I.K., Garda, G.M., 1988. Idades K-Ar de rochas alcalinas do Brasil Meridional e Paraguai Oriental: compilação e adaptação as novas constantes de decaimento. Boletim IG-USP Série Cientifica 19: 63-85.

Thompson, R.N., Gibson, S.A., Mitchell, J.G., Dickin, A.P., Leonardos, O.L., Brod, J.A., Greenwood, J.C., 1998. Migrating Cretaceous-Eocene magmatism in the Serra do Mar alkaline province, SE Brazil: Melts from the deflected Trindade mantle plume? Journal of Petrology 39: 1493-1526.

Toledo M.C.M. 1999. Mineralogia dos principais fosfatos do maciço alcalino-carbonatítico de Catalão I (GO) e sua evolução no perfil laterítico. Professorship Tesis. Instituto de Geociências, Universidade de São Paulo, 198pp.

Toledo, M. C. M., Pereira, V. P. 2001. A variabilidade de composição da apatita associada a carbonatitos. Revista do Instituto Geológico, São Paulo, 22: 24-64.

Toledo M. C. M. de, Ferrari V.C., Alcover Neto A., Fontan F., Martin F., Santos C.N., Carvalho F.M.S. 2002. Fosfatos aluminosos com ferro do grupo da crandallita nas coberturas lateríticas de Catalão I, Juquiá e Tapira, Brasil, e Chiriguelo, Paraguai. Revista Brasileira de Geociências 32(4): 389- 402.

Toledo, M. C. M., Pereira, V. P. 2003. Ocorrência e variabilidade de composição dos fosfatos do grupo da monazita em carbonatitos. Pesquisas em Geociências, Instituto de Ggeociências, UFGRS, Porto Alegre, Brazil. 3-(1): 83-98. 
Toledo M.C.M., Oliveira S.M.B., Ferrari V.C., Fontan F., Parseval P., 2004a. Mineralogia, morfologia e cristaloquímica da monazita de Catalão I, (GO, Brasil). Revista Brasileira de Geociências 34 (1): 135-146.

Toledo M.C.M., Lenharo, S. L. R., Ferrari V.C., Fontan F., Parseval P., Leroy, G. 2004b. The compositiona evolution of apatite in the weathering profile of the Catalão I alkaline-carbonatitic complex, Goiás, Brazil. The Canadian Mineralogist 42: 1139-1158.

Toyoda, K., Horiuchi, H., Tokonami, M., 1994. Dupal anomaly of Brazilian carbonatites - geochemical correlations with hotspots in the South-Atlantic and implications for the mantle source. Earth and Planetary Science Letters 126: 315-331.

Traversa G., Gomes C.B., Brotzu P., Buraglini N., Morbidelli L., Principato M.L., Ronca S., Ruberti E. 2001. Petrography and mineral chemistry of carbonatites and mica-rich rocks from the Araxá Complex. Anais da Academia Brasileira de Ciências 73(1): 71-98.

Ulbrich, H.H.G.J., Gomes, C.B., 1981. Alkaline rocks from continental Brazil. Earth-Science Reviews 17: 135154.

VanDecar, J.C., James, D.E., Assumpção, M., 1995. Seismic evidence for a fossil mantle plume beneath South America and implications for plate driving forces. Nature 378: 25-31.

Wall F. \& Mariano A.N. 1996. Rare earth minerals in carbonatites: a discussion centred on the Kangankunde Carbonatite, Malawi. In: A.P. Jones, F. Wall, C.T. Williams (eds.) Rare Earth minerals, The Mineralogical Series. 7, The Mineralogical Society, London. 193-226.

Walter, A. V., Nahon, D., Flicoteaux, R., Girard, J.P., Melfi, A.J. 1995. Behaviour of major and trace elements and fractionation of REE under tropical weathering of a typical apatite-rich carbonatite from Brazil. Earth and Planetary Sciences Review 136: 591-602.

Wilson, M. J. 1999. The Origin and formation of clay minerals in soils: past, present and future perspectives. Clay Minerals 34: 7-25.

Wilson, M. J. 2004. The Weathering of the primary rockforming minerals: processes, products and rates. Clay Minerals, 39: 233-266.

Woolley A.R. 1987. Alkaline Rocks and Carbonatites of the World. Part 1: North and South America. British Museum (Natural History)/University of Texas Press, London. 216 pp. 


\section{Capítulo 3}

\section{Conclusões}

O perfil de intemperismo desenvolvido sobre os bebedouritos de Salitre apresenta diversas similaridades com outros perfis de intemperismo sobre outros complexos alcalinocarbonatíticos estudados (Morteani and Preinfalk, 1996; Oliveira and Imbernon, 1998; Brod et al., 2001; Toledo and Pereira; 2003; Wilson, 2004; Freyssinet, 2005, Ribeiro, 2008; Azzone and Rubertti, 2010; Barbosa, 2012). A distribuição mineralógica e abundância relativa são mostrados na Figure 2.17.

A olivina é fortemente serpentinizada e prontamente intemperizada para argilominerais interestratificados impregnados com óxidos-hidróxidos de Fe no horizonte isalterítico. A presença de olivina e seus produtos de alteração estão restritos ao bebedourito do tipo B1a. O diopsídio é mais resistente ao intemperismo que a olivina: frequentemente apresenta fragmentos residuais imersos em argilas interestratificadas enriquecidas em $\mathrm{Fe}$, com diferentes níveis de impregnação por óxidos-hidróxidos de Fe. A presença deste tipo de textura no saprolito isalterítico indica um bebedourito do tipo B1b como rocha primária original. A flogopita começa a intemperizar no horizonte de rocha alterada, com a remoção do $\mathrm{K}^{+}$intercamada. $\mathrm{O}$ material resultante é inicialmente composto por vermiculita rica em $\mathrm{Mg}$ interestratificada com flogopita residual. Em porções mais evoluídas do perfil, principalmente a Isalterita Micácea de Base e Isalterita Micácea de Topo, a vermiculita é substituída por esmectitas ricas em Mg e Fe. Azzone et al. (2010) observou uma mineralogia similar para o depósito de Catalão I.

Os alteromorfos da flogopita depletados em $\mathrm{K}$ (Mg-vermiculita principalmente) preservam a morfologia dos cristais de flogopita no horizonte isalterítico micáceo de base. Essa textura associada à presença de minerais como a perovskita, apatita e magnetita, mais resistentes ao intemperismo, permite o reconhecimento da textura e composição do protolito em escala macroscópica. Camadas deformadas de vermiculita impregnadas com óxidoshidróxidos de Fe são frequentes no Isalterito Micáceo de Topo. A vermiculita é gradualmente substituída por óxidos-hidróxidos de Fe no Isalterito Oxidado. 
A apatita é uma fase estável no horizonte isalterítico, atingindo concentrações econômicas. A maior parte da apatita presente no perfil estudado é de origem ígnea, rica em F com traços de Sr. Sr foi observado na apatita de Catalão I (Lenharo, 1994; Pereira, 1995) em associação ao F. No presente trabalho, apatitas de origem carbonatítica apresentam os mais altos teores de ETR, Sr e Na. A apatita intempérica é uma fluorapatita sem elementos traço detectáveis. Análises posteriores de WDS poderão confirmar a ausência de Na e Sr na apatita secundária.

A crandalita é abundante na Aloterita de Base, formando uma solução sólida com gorceixita $(\mathrm{Ba})$ e goyazita $(\mathrm{Sr})$. Os valores de $\mathrm{SiO} 2$ aumentam nos minerais do grupo da crandalita com a evolução do intemperismo.

O anatásio está presente em todo o perfil de intemperismo, atingindo as maiores concentrações na Aloterita de Base (até 30\% em peso). Como o anatásio deriva da alteração/intemperismo da perovskita, supõe-se que a concentração máxima é resultado de acumulação residual de um protolito com um forte componente bebedourítico. A alteração intempérica da perovskita para anatásio é gradual e progride a partir da Isalterita Micácea de Base até o topo do perfil. Na Aloterita de Base toda a perovskita se encontra alterada para anatásio, formando holo-alteromorfos. Este anatásio apresenta textura complexa, é microcristalino e extremamente poroso, contendo monazita acicular neoformada. A associação anatásio-monazita sugere que os ETR contidos na estrutura da perovskita (média de $1,5 \%$ de $\mathrm{REE}_{2} \mathrm{O}_{3}$ ) não são estáveis na estrutura do anatásio e complexam com o $\mathrm{P}_{2} \mathrm{O}_{5}$ disponível a partir da desestabilização da apatita na Aloterita de Base, gerando a monazita.

O anatásio metassomático é frequentemente associado ao magnesiocarbonatito do tipo D4, rico em Sr e Ba. A fase portadora de Ba nessas amostras é a barita, indicando uma condição mais oxidante. Nas amostras estudadas, a geração de anatásio metassomático parece restrita à interação do bebedourito rico em perovskita e o magnesiocarbonatito do tipo D4. Essa interpretação é consistente com o fato de que perovskita de bebedouritos intrudidos por calciocarbonatitos do tipo C3 está inalterada.

Os maiores teores de $\mathrm{REE}_{2} \mathrm{O}_{3}$ no perfil de intemperismo de Salitre I estão relacionados à presença de pseudomorfos de monazita sobre carbonatos. A morfologia romboédrica e um grão de calcita parcialmente preenchido por monazita encontrado na rocha fresca suportam a interpretação do pseudomorfismo da monazita sobre carbonatos. Kasioptas et al. (2010) sintetizaram fosfatos policristalinos do grupo da apatita sobre carbonatos de cálcio em baixas 
temperaturas (cerca de $300^{\circ} \mathrm{C}$ ). A apatita policristalina resultante manteve a morfologia romboédrica dos cristais de calcita, com maior porosidade. Este estudo e as observações deste trabalho sugerem que esta monazita tem origem hidrotermal, mas novos estudos são necessários para confirmar esta hipótese. A monazita secundária derivada da alteração perovskita/anatásio é frequentemente pequena $(<5 \mu \mathrm{m})$ e encapsulada pela fase de $\mathrm{Ti}$, enquanto a monazita pseudomórfica é maior (> 100 $\mu \mathrm{m})$ e liberada. Todos os tipos de monazita analisados apresentam baixos teores de Th $(<2 \mathrm{wt}$. \%). Baixos teores de Th em monazitas também são observados em Catalão I (Toledo, 2004) e são atípicos. A monazita dos carbonatitos em Kola (Chakhmouradian and Mitchell, 1998) e na Argentina (Del Blanco et al, 1998) mostram valores de $\mathrm{Th}_{2} \mathrm{O}_{5}$ maiores que 5 wt. \%. O tamanho, ocorrência e baixo teor de Th fazem deste tipo de monazita um importante portador de ETR passível de extração econômica.

A origem e associação da Aloterita de topo é incerta. A base deste horizonte contém grandes volumes de caolinita que gradualmente dá lugar a gibbsita como principal constituinte em direção ao topo. A presença de caolinita e gibbsita no horizonte superior à Aloterita de Base (depletada em Si e Al) sugere que a Aloterita de Topo é alóctone. A ausência da acumulação residual de fases mais estáveis ao intemperismo abundantes nos níveis inferiores, como anatásio e magnetita, é outra forte evidência da origem alóctone do material. Contudo a assinatura química é similar à da rocha fresca e outros alteritos, exceto por um pequeno enriquecimento em terras raras pesados. Esse fato sugere que a Aloterita de Topo é derivada de rochas alcalinas e carbonatitos similares à rocha fresca e que se sua natureza alóctone for comprovada, o material se originou nos limites da intrusão alcalinocarbonatítica. 


\section{Capítulo 4}

\section{Referências bibliográficas}

Alcover Neto, A. and de Toledo, M.C.M. (1993) Evolução supérgena do carbonatito de Juquiá (SP). Revista do Instituto de Geologia, São Paulo No 14(1): 31-43.

Almeida, F.F.M., 1983. Relações tectônicas das rochas alcalinas mesozóicas da região meridional da Plataforma Sul-Americana. Revista Brasileira de Geociências 13: 139-158.

Almeida, F. F. M., Svisero, D. P. 1991. Structural setting and tectonic control of kimberlite and associated rocks of Brazil. 5th IKC Ext. Abstr., 3-5.

Angélica, R.S. and da Costa, M.L. (1993) Geochemistry of rare- earth elements in surface lateritic rocks and soils from the Maicuru complex, Pará, Brazil. Journal of Geologic Exploration. № 47: $165-182$.

Barbosa E.S.R., 2009. Mineralogia e Petrologia do Complexo Carbonatítico-Foscorítico de Salitre, MG. Tese de Doutoramento. IG/UnB, 434pp.

Barbosa, E. S. R., Brod, J. A., Junqueira-Brod, T. C., Dantas, E. L., Cordeiro, P. F. O., and Gomide, C. S., 2012, Bebedourite from its type area (Salitre I complex): A key petrogenetic series in the Late-Cretaceous Alto Paranaiba kamafugite-carbonatite-phoscorite association, Central Brazil: Lithos, 144: 56-72.

Barker, D. S., 1989. Field relations of carbonatites. In K. Bell (Ed.) Carbonatites: genesis and evolution. London, Unwin Hyman, 38-69.

Bedinger, G., M., 2012. Titanium Mineral Concentrates. Mineral Commodity Summaries, United States Geological Survey.

Berbert, C.O. (1984) Carbonatites and associated mineral deposits in Brazil. Geol. Survey of Japan. Report 263: 269 \pm 290 .

Biondi, J.C., 2005. Brazilian mineral deposits associated with alkaline and alkaline-carbonatite complexes. In: P. Comin-Chiaramonti, C.B. Gomes (Editors), Mesozoic to Cenozoic alkaline magmatism in the Brazilian Platform. EDUSP/FAPESP, São Paulo, Brazil, 707-750pp.

Bizzi, L.A., De Wit, M.J., Smith, C.B., McDonald, I., Armstrong, R.A., 1995. Heterogeneous enriched mantle materials and Dupal-type magmatism along the SW margin of the São Francisco Craton, Brazil. Journal of Geodynamics 20: 469-491.

Bosum W., 1973. O levantamento aeromagnético de Minas Gerais e Espírito Santo e sua sequência quanto à estrutura geológica. Revista Brasileira de Geociências 3: 149-159.

Brod, J. A., 1999. Petrology and geochemistry of the Tapira alkaline complex, Minas Gerais State, Brazil. University of Durham, UK (Tese de Doutoramento). 
Brod, J. A., Gibson, S. A., Thompson, R. N. Junqueira-Brod, T. C. Seer, H. J., Moraes, L. C., Boaventura, G. R. 2000. Kamafugite affinity of the Tapira alkaline-carbonatite complex (Minas Gerais, Brazil). Revista Brasileira de Geociências 30: 404-408.

Brod, J.A., Gaspar, J.C., Araújo, D.P., Gibson, S.A., Thompson, R.N., Junqueira-Brod, T.C., 2001. Phlogopite and tetra-ferriphlogopite from Brazilian carbonatite complexes: petrogenetic constraints and implications for mineral-chemistry systematics. Journal of Asian Earth Sciences 19: 265-296.

Brod, J.A., Ribeiro, C.C., Gaspar, J.C., Junqueira-Brod, T.C., Barbosa, E.S.R., Riffel, B.F., Silva, J.F., Chaban, N., Ferrari, A.J.D., 2004. Guia de excursão 1: Geologia e Mineralizações dos Complexos Alcalino-Carbonatíticos da Província Ígnea do Alto Paranaíba. 42 Congresso Brasileiro de Geologia, Araxá, Brasil.

Brod J.A., Gaspar J. C., Diniz-Pinto H. S., Junqueira-Brod T.C., 2005. Spinel chemistry and petrogenetic processes in the Tapira alkaline-carbonatite complex, Minas Gerais, Brazil. Revista Brasileira de Geociências 35 (1): 23-32.

Campbell, L. S., Henderson, P., 1997. Apatite paragenesis in the Bayan Obo REE-Nb-Fe ore deposit, Ineer Mongolia, China. Lithos 42: 89-103.

Carlson, R.W., Esperança, S., Svisero, D.P., 1996. Chemical and Os isotopic study of Cretaceous potassic rocks from Southern Brazil. Contributions to Mineralogy and Petrology 125: 393-405.

Carlson, R.W., Araújo, A.L.N., Junqueira-Brod, T.C., Gaspar, J.C., Brod, J.A., Petrinovic, I.A., Holanda, M.H.B.M., Pimentel, M.M., Sichel, S., 2007. Chemical and isotopic relationships between peridotite xenoliths and mafic-ultrapotassic rocks from Southern Brazil. Chemical Geology 242: 415-434.

Chatelin, Y. 1974. Les soils ferrallitiques. 111. L'alteration. Office Rech. Sci. Techn. Outre-Mer (ORSTOM, Paris), Initiations, Doe. Techn. 24: 144 pp.

Comin-Chiaramonti, P., Gomes, C.B. (Editors), 1996. Alkaline magmatism in Central-Eastern Paraguay. In: Relationships with coeval magmatism in Brazil. EDUSP/FAPESP, São Paulo, Brazil.

Comin-Chiaramonti, P., Cundari, A., Piccirillo, E.M., Gomes, C.B., Castorina, F., Censi, P., DeMin, A., Marzoli, A., Speziale, S., Velazquez, V.F., 1997. Potassic and sodic igneous rocks from eastern Paraguay: Their origin from the lithospheric mantle and genetic relationships with the associated Paraná flood tholeiites. Journal of Petrology 38: 495-528.

Comin-Chiaramonti, P., Gomes, C. B. (Editors), 2005. Mesozoic to Cenozoic alkaline magmatism in the Brazilian Platform. EDUSP/FAPESP, São Paulo, Brazil, 751 pp.

Cordeiro, P.F.O., Brod, J.A., Santos, R.V., 2009. Stable (C,O) and radiogenic (Sr;Nd) isotopes of carbonates as indicators of magmatic and post-magmatic processes of phoscorite-series rocks 
and carbonatites from Catalao I, central Brazil. Contributions to mineralogy and petrology 161: 454-464.

Cordeiro, P. F. O., Brod, J. A., Dantas, E. L., and Barbosa, E. S. R., 2010, Mineral chemistry, isotope geochemistry and petrogenesis of niobium-rich rocks from the Catalão I carbonatite-phoscorite complex, Central Brazil: Lithos 118: 223-237.

Cordeiro, P. F. O., Brod, J. A., Palmieri, M., Oliveira, C. G., Barbosa, E. S. R., Santos, R. V., Gaspar, J. C., and Assis, L. C., 2011, The Catalão I niobium deposit, central Brazil: resources, geology and pyrochlore chemistry: Ore Geology Reviews 41: 112-121.

Crough S.T., Morgan W.J., Hargraves R.B., 1980. Kimberlites: their relation to mantle hotspots. Earth and Planetary Science Letters 50: 260-274.

Danni, J.C.M., Baecker, M.L., Ribeiro, C.C., 1991. The geology of the Catalão I carbonatite complex. 5th International Kimberlite Conference. CPRM, Araxá, Brazil, 25-30.

Deans, T., 1966. Economic mineralogy of African carbonatites. In: Carbonatites, O.F. Tuttle \& J. Gittins (editors), New York, Wiley. 385-413.

Deer, W.A., Howie, R.A., Zussman, J., 1992. An introduction to rock-forming minerals. Longman, Essex, 696 pp.

Delvigne, J. E. 1998. Atlas of Micromofphology of Mineral Alteration and Weathering. The Canadian Mineralogis Special Publication 3: 494 pp.

Duddy, I. R. 1980. Reditribution and fractionation of rare-earth and other elements in a weathering profile. Chemical Geologoy 30: 363-381.

Eriksson, S.C., 1989. Phalaborwa: A saga of magmatism, metasomatism and miscibility. In: K. Bell (Editor) Carbonatites: genesis and evolution. Unwin Hyman, London, 221-254 pp.

Fava N., 2001. O manto de intemperismo e a química do pirocloro de Catalão I: um estudo preliminar. Dissertação de Mestrado. Universidade de Brasília, Brasília, Brasil.

Gibson, S.A., Thompson, R.N., Leonardos, O.H., Dickin, A.P., Mitchell, J.G., 1995a. The Late Cretaceous impact of the Trindade mantle plume - evidence from large-volume, mafic, potassic magmatism in SE Brazil. Journal of Petrology 36: 189-229.

Gibson, S.A., Thompson, R.N., Dickin, A.P., Leonardos, O.H., 1995b. High-Ti and low-Ti mafic potassic magmas: Key to plume-lithosphere interactions and continental flood-basalt genesis. Earth and Planetary Science Letters 136: 149-165.

Gibson, S.A., Thompson, R.N., Weska, R.K., Dickin, A.P., Leonardos, O.H., 1997. Late Cretaceous rift-related upwelling and melting of the Trindade starting mantle plume head beneath western Brazil. Contributions to Mineralogy and Petrology 126: 303-314. 
Gierth E., Baecker M.L., 1986. A mineralização de nióbio e as rochas alcalinas associadas no complexo Catalão I, Goiás. In C. Schobbenhaus (Ed.), Principais depósitos minerais do Brasil. Brasília, MME/DNPM, 2: 455-462.

Gonzaga, G.M., Tompkins, L.A., 1991. Geologia do diamante. In: Principais depósitos minerais do Brasil. Brasília: DNPM/CPRM 4a: 42-58.

Herz, N., 1977. Timing of spreading in the South Atlantic: information from Brazilian alkalic rocks. Geological Society of America Bulletin 88: 101-112.

Hirano, H., Kamitani, T., Sato, T. and Sudo, S. 1987. Niobium mineralization of Catalão I carbonatite complex, Goiás, Brazil. Geol. Survey of Japan Report 263: 23-55.

Hogarth, D.D., Hartree, J.L., Solberg, T.N., 1985. Rare-element minerals in four carbonatites near Gatineau, Quebec. American Mineralogist 70: 1135-1142.

Hogarth, D. D., 1989. Pyrochlore, apatite and amphibole: distinctive minerals in carbonatite. In K. Bell (Ed.) Carbonatites: genesis and evolution. London, Unwin Hyman, 105-148.

Imbernon R.A.L., Oliveira S.M.B., Figueiredo A.M., 1994. Concentração dos ETR nos produtos de alteração intempérica do complexo alcalino-carbonatíticos de Catalão I, GO. Boletim Geoc. Centro-Oeste, 17: 25-28.

Junqueira-Brod, T.C., 1998. Cretaceous alkaline igneous rocks from the Águas Emendadas region, Goiás, Central Brazil. Dissertação de Mestrado, Universidade de Durham, UK.

Junqueira-Brod, T.C., Brod, J.A., Gibson, S.A., Thompson, R.N., 2000. Mineral chemistry of kamafugites and related rocks from Águas Emendadas region, Goiás state. Revista Brasileira de Geociências 30: 403-407.

Junqueira-Brod, T.C., Roig, H.L., Gaspar, J.C., Brod, J.A., Meneses, P.R., 2002. A Província Alcalina de Goiás e a extensão de seu vulcanismo kamafugítico. Revista Brasileira de Geociências 32: 559-566.

Junqueira-Brod, T.C., Gaspar, J.C., Brod, J.A., Jost, H., Barbosa, E.S.R., Kafino, C.V. 2005. Emplacement of Kamafugite Lavas from the Goiás Alkaline Province, Brazil: Constraints from whole-rock simulations. Journal of South American Earth Sciences 18: 323-335.

Kamitani, M. and Hirano, H. (1987) AraxaÂ carbonatite deposit and its lateritization. Geol. Survey of Japan. Report 263, 56-73.

Le Bas, M. J., 1985. Nephelinites and Carbonatites. Journal of the Geological Society of London 142: 704.

Le Roex, A.P., Lanyon, R., 1998. Isotope and trace element geochemistry of Cretaceous Damaraland lamprophyres and carbonatites, Northwestern Namibia: evidence for plume-lithosphere interactions. Journal of Petrology 39: 1177-1146. 
Leonardos, O. H., Ulbrich, M. N., Gaspar, J. C. 1991. The Mata da Corda volcanic rocks. 5th IKC. Field guide, 65-73.

Lloyd, F.E., Bailey, D.K., 1991. Complex mineral textures in bebedourite: possible links with alkali clinopyroxenite xenoliths and kamafugitic volcanism. In O. H. Leonardos, H. O. A. Meyer and J. C. Gaspar, Eds., 5th International Kimberlite Conference (Extended Abstracts). Araxá, Brazil, CPRM, Special Publication 3/91: 263-269.

Mariano, A.N., 1989. Nature of economic mineralization in carbonatites and related rocks. In: K. Bell (Ed.) Carbonatites: genesis and evolution. London, Unwin Hyman, 149-176.

Mariano A.N., Marchetto M. 1991. Serra Negra and Salitre carbonatite alkaline igneous complex. In O.H. Leonardos, H.O.A. Meyer, J.C. Gaspar (Eds.), 5th IKC. (Field Guide Book). Araxá, CPRM, Sp. Publ. 3/91: 75-79.

Melo M.T.V., 1997. Depósitos de Fosfato, Titânio e Nióbio de Tapira, Minas Gerais. In: C. Schobbenhaus, E.T. Queiroz, C.E.S. Coelho (Eds.) Principais depósitos minerais do Brasil. DNPM/CPRM, Brasília, 41-56.

Milner, S.C., Le Roex, A.P., O'Connor, J.M., 1995. Age of Mesozoic igneous rocks in northwestern Namibia, and their relationship to continental breakup. Journal of Geological Society of London 152: 97-104.

Milner, S.C., Le Roex, A.P., 1996. Isotope characteristics of the Okenyenya igneous complex, northwestern Namibia: constraints on the composition of the early Tristan plume and the origin of the EM1 mantle component. Earth and Planetary Science Letters 141: 277-291.

Morbidelli, L., Gomes, C.B., Beccaluva, L., Brotzu, P., Conte, A.M., Ruberti, E., Traversa, G., 1995a. Mineralogical, petrological and geochemical aspects of alkaline and alkaline-carbonatite associations from Brazil. Earth-Science Reviews 39: 135-168.

Morbidelli, L., Beccaluva, L., Brotzu, P., Conte, A.M., Garbarino, C., Gomes, C.B., Grossi-Sad, J.H., Riffel, B.F., Ruberti, E., Traversa, G., 1995b. Aspectos mineralógicos e petrográficos de rochas ultramáficas e carbonatitos do complexo alcalino de Salitre, GO. $5^{\circ}$ Congresso Brasileiro de Geoquímica. SBGq, Niteroi, Brazil (CD-ROM).

Morbidelli, L., Gomes, C.B., Beccaluva, L., Brotzu, P., Garbarino, C., Riffel, B.F., Ruberti, E., Traversa, G., 1997. Parental magma characterization of Salitre cumulate rocks (Alto Paranaíba Alkaline Province, Brazil) as inferred from mineralogical, petrographic, and geochemical data. International Geology Review 39: 723-743.

Morteani G. \& Preinfalk C. 1996. REE distribution and REE carriers in laterites formed on the alkaline complexes of Araxá and Catalão (Brasil). A.P. Jones, F. Wall, C.T. Williams (eds.) Rare Earth minerals, The Mineralogical Series 7, The Mineralogical Society, Londres, 227-256. 
Neumann, R., Lapido-Loureiro, E. V. 1993. Caracterização mineralógica e litogeouqímica dos depósitos de elementos de terras raras do córrego do Garimpo (Catalão), Morro do Ferro (Poços de Caldas, MG) e Barreiro-Araférticl (Araxá, MG). 4o Congresso Brasileiro de Geoquímica, Brasília. 189-192.

Neumann, R. 1994. Origem do minério de terras raras do córrego do Garimpo, Catalão, GO. 38o Congresso Brasileiro de Geologia, Camboriú, 2: 182-183.

Neumann R. 1999. Caracterização tecnológica dos potenciais minérios de terras-raras de Catalão I, GO. Tese de Doutoramento, Instituto de Geociências, Universidade de São Paulo, 204pp.

Oliveira, S. M. B., Trescases, J.J. and Melfi, A. J. 1992. Lateritic nickel deposits of Brazil. Mineralium Deposita 27 (2): 137-146.

Oliveira, S. M. B, Imbernon, R. A. L. 1998. Weathering alteration and related REE concentration in the Catalão I carbonatite complex, central Brazil, Journal of South American Earth Sciences. Vol 11, No 4: 379-388.

Pereira V.P. 1995. Alteração no Maciço Alcalino-carbonatítico de Catalão I (GO, Brasil). Evolução mineralógica. Tese de Doutoramento, Instituto de Geociências, Universidade Federal do Rio Grande do Sul, 279p.

Petrov, S.V., 2004. Economic deposits associated with the alkaline and ultrabasic complexes of the Kola Peninsula. In: Phoscorites and Carbonatites from Mantle to Mine: the Key Example of the Kola Alkaline Province (F. Wall and A.N. Zaitsev, editors) Mineralogical Society Series, 469$490 \mathrm{pp}$.

Ribeiro, C.C., 2008. Geologia, geometalurgia, controles e gênese dos depósitos de fósforo, terras raras e titânio do Complexo Carbonatítico de Catalão I, GO. Tese de Doutoramento, Universidade de Brasília, Brasil.

Sandvik, P.O., Erdosh, G., 1977. Geology of the Cargill phosphate deposit in northern Ontario. Canadian Mining and Metallurgical Bulletin 69: 90-96.

Seer, H.J., Moraes, L.C., 1988. Estudo petrográfico das rochas ígneas alcalinas da região de Lagoa Formosa, MG. Revista Brasileira de Geociências 18: 134-140.

Sgarbi, P.B.A., Gaspar, J.C., 1995. Perovskites from the Mata da Corda kamafugites, MG, Brazil. 6th International Kimberlite Conference. Novosibirsk, Russia. 498-499.

Sgarbi, P.B.A., Heanman, L.M., Gaspar, J.C., 2004. U-Pb perovskite ages for brazilian kamafugitic rocks: further support for a temporal link to a mantle plume hotspot track. Journal of South American Earth Sciences 16: 715-724.

Sonoki, I.K., Garda, G.M., 1988. Idades K-Ar de rochas alcalinas do Brasil Meridional e Paraguai Oriental: compilação e adaptação as novas constantes de decaimento. Boletim IG-USP Série Cientifica 19: 63-85. 
Soubiés, F., Melfi, A. J., Autefage, F. 1990. Geochemical behaviour of rar Earth elements in alterites of phosphate and titanium ore depoists in Tapira (Minas Gerais, Brazil): The imporance of the phosphates. Geochemistry of the earth's surface and of Mineral Formation $2^{\text {nd }}$ International Symposium, Aix en Provence, França. 377.

Stoppa, F., Cundari, A., 1995. A new Italian carbonatite occurrence at Cupaello (Rieti) and its genetic significance. Contributions to Mineralogy and Petrology 122: 275-288.

Thompson, R.N., Gibson, S.A., Mitchell, J.G., Dickin, A.P., Leonardos, O.L., Brod, J.A., Greenwood, J.C., 1998. Migrating Cretaceous-Eocene magmatism in the Serra do Mar alkaline province, SE Brazil: Melts from the deflected Trindade mantle plume? Journal of Petrology 39: 1493-1526.

Toledo M.C.M. 1999. Mineralogia dos principais fosfatos do maciço alcalino-carbonatítico de Catalão I (GO) e sua evolução no perfil laterítico. Tese de Livre Docência, Instituto de Geociências, Universidade de São Paulo.

Toledo M.C.M., Oliveira S.M.B., Ferrari V.C., Fontan F., Parseval P., 2004a. Mineralogia, morfologia e cristaloquímica da monazita de Catalão I, (GO, Brasil). Revista Brasileira de Geociências 34 (1): 135-146.

Toledo M.C.M., Lenharo, S. L. R., Ferrari V.C., Fontan F., Parseval P., Leroy, G. 2004b. The compositional evolution of apatite in the weathering profile of the Catalão I alkaline-carbonatitic complex, Goiás, Brazil. The Canadian Mineralogist 42: 1139-1158.

Topp, S. E., Salbu, B., Roaldset, E., Jorgensen, P. 1985. Vertical distribution of trace elements in lateritic soil (Suriname). Chemical Geology 47: 159-174.

Toyoda, K., Horiuchi, H., Tokonami, M., 1994. Dupal anomaly of Brazilian carbonatites geochemical correlations with hotspots in the South-Atlantic and implications for the mantle source. Earth and Planetary Science Letters 126: 315-331.

Ulbrich, H.H.G.J., Gomes, C.B., 1981. Alkaline rocks from continental Brazil. Earth-Science Reviews 17: 135-154.

VanDecar, J.C., James, D.E., Assumpção, M., 1995. Seismic evidence for a fossil mantle plume beneath South America and implications for plate driving forces. Nature 378: 25-31.

Walter, A. V., Nahon, D., Flicoteaux, R., Girard, J.P., Melfi, A.J. 1995. Behaviour of major and trace elements and fractionation of REE under tropical weathering of a typical apatite-rich carbonatite from Brazil. Earth and Planetary Sciences Review 136: 591-602.

Woolley, A.R., Kjarsgaard, B.A., 2008. Paragenetic types of carbonatite as indicated by the diversity and relative abundances of associated silicate rocks: evidence from a global database. Canadian Mineralogist 46: 741 - 752.

Yang, Z., Woolley, A.R., 2006. Carbonatites in China: a review. Journal of Asian Earth Sciences 27: 559-575. 
Yegorov, L.S., 1993. Phoscorites of the Maymecha-Kotuy ijolite-carbonatite association. International Geology Review 35: 346-358. 
5. Anexos 
Análises químicas de rocha total I.

\begin{tabular}{|c|c|c|c|c|c|c|c|c|c|c|c|c|c|c|c|c|c|c|}
\hline Rocha & $\begin{array}{l}\text { Olivina- } \\
\text { Beb. }\end{array}$ & Carb. & Fosc. & $\begin{array}{l}\text { Olivina- } \\
\text { Beb. }\end{array}$ & Fosc. & Beb. & Beb. & Beb. & Beb. & Beb. & $\begin{array}{c}\text { Pirox. } \\
\text { Beb. }\end{array}$ & Beb. & Beb. & $\begin{array}{l}\text { Beb./ } \\
\text { Fosc. }\end{array}$ & Beb. & Beb. & Beb. & Beb. \\
\hline Intemp. & $\begin{array}{l}\text { Rocha } \\
\text { Fresca }\end{array}$ & $\begin{array}{l}\text { Rocha } \\
\text { Fresca }\end{array}$ & $\begin{array}{l}\text { Rocha } \\
\text { Fresca }\end{array}$ & $\begin{array}{l}\text { Rocha } \\
\text { Fresca }\end{array}$ & $\begin{array}{l}\text { Rocha } \\
\text { Fresca }\end{array}$ & $\begin{array}{l}\text { Rocha } \\
\text { Fresca }\end{array}$ & $\begin{array}{l}\text { Isalterito } \\
\text { Micáceo } \\
\text { de Base }\end{array}$ & $\begin{array}{c}\text { Isalterito } \\
\text { Micáceo } \\
\text { de Base }\end{array}$ & $\begin{array}{l}\text { Isalterito } \\
\text { Micáceo } \\
\text { de Base }\end{array}$ & $\begin{array}{l}\text { Isalterito } \\
\text { Oxidado }\end{array}$ & $\begin{array}{l}\text { Isalterito } \\
\text { Micáceo } \\
\text { de base }\end{array}$ & $\begin{array}{c}\text { Isalterito } \\
\text { Micáceo } \\
\text { de topo }\end{array}$ & $\begin{array}{l}\text { Isalterito } \\
\text { Micáceo } \\
\text { de topo }\end{array}$ & $\begin{array}{l}\text { Isalterito } \\
\text { Oxidado }\end{array}$ & $\begin{array}{c}\text { Aloterita } \\
\text { Base }\end{array}$ & $\begin{array}{l}\text { Aloterita } \\
\text { Base }\end{array}$ & $\begin{array}{l}\text { Aloterita } \\
\text { Base }\end{array}$ & $\begin{array}{c}\text { Aloterita } \\
\text { Base }\end{array}$ \\
\hline Prof. (m) & 167,35 & 166,25 & 164,9 & 164,9 & 161 & 161 & 157,1 & 152,9 & 145 & 140,2 & 132 & 129,8 & 126,8 & 120,9 & 116,3 & 114,2 & 106,1 & 102 \\
\hline Análise & 1 & 2 & 3 & 4 & 5 & 6 & 7 & 8 & 9 & 10 & 11 & 12 & 13 & 14 & 15 & 16 & 17 & 18 \\
\hline $\mathrm{SiO}_{2}$ & 25,11 & 0,64 & 18,14 & 31,33 & 20,84 & 26,25 & 26,80 & 21,06 & 20,97 & 0,87 & 27,74 & 6,86 & 3,00 & 1,13 & 0,40 & 20,70 & 25,80 & 3,40 \\
\hline $\mathrm{TiO}_{2}$ & 8,79 & 0,55 & 8,90 & 7,28 & 4,27 & 4,20 & 7,78 & 11,66 & 10,22 & 26,21 & 9,89 & 11,68 & 8,65 & 5,23 & 32,58 & 13,22 & 15,98 & 23,93 \\
\hline $\mathrm{Al}_{2} \mathrm{O}_{3}$ & 3,98 & 0,01 & 3,85 & 6,77 & 2,97 & 3,05 & 4,28 & 3,03 & 5,96 & 0,92 & 8,73 & 2,97 & 2,92 & 2,04 & 2,68 & 3,03 & 3,19 & 4,64 \\
\hline $\mathrm{Fe}_{2} \mathrm{O}_{3}$ & 10,99 & 3,87 & 14,32 & 12,35 & 12,31 & 10,31 & 8,89 & 17,25 & 12,74 & 32,94 & 12,36 & 21,88 & 34,38 & 28,79 & 44,90 & 40,81 & 34,43 & 47,60 \\
\hline $\mathrm{MnO}$ & 0,27 & 0,16 & 0,35 & 0,22 & 0,29 & 0,28 & 0,35 & 0,28 & 0,28 & 0,87 & 0,35 & 0,50 & 4,37 & 2,70 & 1,32 & 1,40 & 1,41 & 1,03 \\
\hline $\mathrm{MgO}$ & 17,08 & 3,60 & 15,43 & 21,70 & 20,03 & 24,22 & 24,58 & 11,68 & 15,40 & 1,26 & 17,94 & 4,08 & 0,54 & 0,51 & 1,84 & 1,60 & 2,50 & 2,89 \\
\hline $\mathrm{CaO}$ & 13,64 & 48,45 & 16,12 & 3,52 & 17,51 & 13,83 & 9,28 & 16,56 & 12,16 & 18,35 & 3,68 & 25,59 & 10,83 & 21,14 & 0,66 & 0,55 & 0,59 & 0,71 \\
\hline $\mathrm{Na}_{2} \mathrm{O}$ & 0,16 & 0,03 & 0,14 & 0,13 & 0,11 & 0,11 & 0,12 & 0,22 & 0,05 & 0,13 & 0,02 & 0,12 & 0,11 & 0,14 & 0,03 & 0,05 & 0,03 & 0,04 \\
\hline $\mathrm{K}_{2} \mathrm{O}$ & 6,01 & 0,05 & 4,05 & 6,72 & 3,30 & 3,80 & 0,29 & 0,34 & 0,28 & 0,13 & 0,05 & 0,08 & 0,10 & 0,02 & 0,01 & 0,05 & 0,04 & 0,04 \\
\hline $\mathrm{P}_{2} \mathrm{O}_{5}$ & 4,22 & 0,39 & 7,43 & 0,25 & 3,46 & 1,73 & 5,28 & 6,18 & 6,93 & 9,32 & 1,29 & 16,97 & 11,04 & 19,35 & 4,05 & 4,07 & 3,77 & 4,49 \\
\hline $\mathrm{BaO}$ & 0,17 & 0,22 & 0,16 & 0,26 & 0,13 & 0,18 & 0,05 & 0,09 & 0,06 & 0,31 & 0,04 & 0,12 & 0,57 & 0,34 & 0,29 & 0,37 & 0,12 & 0,18 \\
\hline $\mathrm{SrO}$ & 0,28 & 1,29 & 0,42 & 0,49 & 0,50 & 0,40 & 0,15 & 0,18 & 0,17 & 0,37 & 0,05 & 0,32 & 0,21 & 0,64 & 0,38 & 0,45 & 0,45 & 0,57 \\
\hline LOI & 8,93 & 38,00 & 9,67 & 8,38 & 10,65 & 11,05 & 12,20 & 10,55 & 14,35 & 2,80 & 17,65 & 6,53 & 10,65 & 7,16 & 5,37 & 5,51 & 5,23 & 6,02 \\
\hline TOTAL & 99,63 & 97,25 & 98,98 & 99,43 & 96,42 & 99,42 & 100,05 & 99,11 & 99,57 & 94,50 & 99,79 & 97,72 & 87,40 & 89,21 & 94,56 & 91,84 & 93,57 & 95,58 \\
\hline $\mathrm{S}$ & $<0,01$ & 1,5 & $<0,01$ & 0,2 & 1,06 & 0,33 & $<0,01$ & $<0,01$ & $<0,01$ & $<0,01$ & $<0,01$ & $<0,01$ & $<0,01$ & $<0,01$ & $<0,01$ & 0,01 & $<0,01$ & $<0,01$ \\
\hline $\mathrm{V}$ & 123,2 & 41,1 & 280,3 & 205,3 & 233,9 & 105,3 & 135,7 & 373,1 & 194,6 & 564,1 & 189,2 & 419,5 & 483,8 & 449,9 & 731,9 & 874,7 & 633,7 & 960,4 \\
\hline $\mathrm{Cr}$ & 73,1 & 43,8 & 102,3 & 526,1 & 643,1 & 58,5 & 58,5 & 380,0 & 131,5 & 219,2 & 87,7 & 87,7 & 160,8 & 233,8 & 496,9 & 306,9 & 277,7 & 423,8 \\
\hline $\mathrm{Ni}$ & 140,0 & 22,9 & 146,3 & 468,3 & 339,8 & 145,1 & 137,4 & 285,0 & 249,4 & 296,5 & 442,8 & 252,0 & 637,5 & 356,3 & 439,0 & 315,6 & 170,5 & 409,7 \\
\hline $\mathrm{Rb}$ & 241,7 & 1,9 & 172,2 & 307,3 & 136,2 & 155,3 & 11,6 & 15,6 & 10,6 & 8,0 & 2,6 & 5,4 & 5,9 & 1,1 & 0,4 & 3,2 & 2,8 & 2,3 \\
\hline $\mathrm{Sr}$ & $2.589,9$ & $11.826,0$ & $4.009,0$ & $4.600,3$ & $4.576,7$ & $3.831,6$ & $1.448,7$ & $1.797,6$ & $1.844,9$ & $3.677,9$ & 430,5 & $3.110,2$ & $2.388,9$ & $6.918,2$ & $4.044,5$ & $4.825,0$ & $4.671,3$ & 5617,4 \\
\hline $\mathrm{Y}$ & 57,4 & 66,5 & 79,5 & 13,7 & 52,8 & 35,0 & 49,8 & 95,9 & 73,0 & 266,7 & 34,7 & 149,8 & 161,9 & 921,9 & 441,9 & 811,5 & 441,9 & 468,6 \\
\hline $\mathrm{Zr}$ & 159,4 & 75,6 & 356,6 & 113,5 & 913,1 & 278,3 & 367,4 & 682,2 & 229,6 & $1.033,4$ & 237,7 & 502,5 & 684,9 & 909,1 & $1.837,1$ & $1.762,8$ & $1.129,3$ & 2012,7 \\
\hline $\mathrm{Nb}$ & $1.101,5$ & 773,9 & $1.552,1$ & 795,4 & $1.067,2$ & 755,3 & $1.552,1$ & $1.128,7$ & $1.105,8$ & $4.577,6$ & $1.052,8$ & $1.916,9$ & $4.148,5$ & $5.865,1$ & $5.579,0$ & $6.866,4$ & $6.866,4$ & 5865,1 \\
\hline $\mathrm{Ba}$ & $1.618,9$ & $1.808,7$ & $1.490,5$ & $2.813,6$ & $1.166,7$ & $1.646,8$ & 379,6 & 690,0 & 427,6 & $3.115,0$ & 291,4 & $1.010,4$ & $6.129,6$ & $3.662,1$ & $3.126,2$ & $4.064,1$ & $1.272,8$ & 1797,6 \\
\hline
\end{tabular}


Análises químicas de rocha total I (continuação).

\begin{tabular}{|c|c|c|c|c|c|c|c|c|c|c|c|c|c|c|c|c|c|c|}
\hline Rocha & $\begin{array}{l}\text { Olivina- } \\
\text { Beb. }\end{array}$ & Carb. & Fosc. & $\begin{array}{l}\text { Olivina- } \\
\text { Beb. }\end{array}$ & Fosc. & Beb. & Beb. & Beb. & Beb. & Beb. & $\begin{array}{l}\text { Pirox. } \\
\text { Beb. }\end{array}$ & Beb. & Beb. & $\begin{array}{l}\text { Beb./ } \\
\text { Fosc. }\end{array}$ & Beb. & Beb. & Beb. & Beb. \\
\hline Intemp. & $\begin{array}{l}\text { Rocha } \\
\text { Fresca }\end{array}$ & $\begin{array}{l}\text { Rocha } \\
\text { Fresca }\end{array}$ & $\begin{array}{l}\text { Rocha } \\
\text { Fresca }\end{array}$ & $\begin{array}{l}\text { Rocha } \\
\text { Fresca }\end{array}$ & $\begin{array}{l}\text { Rocha } \\
\text { Fresca }\end{array}$ & $\begin{array}{l}\text { Rocha } \\
\text { Fresca }\end{array}$ & $\begin{array}{l}\text { Isalterito } \\
\text { Micáceo } \\
\text { de Base }\end{array}$ & $\begin{array}{l}\text { Isalterito } \\
\text { Micáceo } \\
\text { de Base }\end{array}$ & $\begin{array}{l}\text { Isalterito } \\
\text { Micáceo } \\
\text { de Base }\end{array}$ & $\begin{array}{l}\text { Isalterito } \\
\text { Oxidado }\end{array}$ & $\begin{array}{l}\text { Isalterito } \\
\text { Micáceo } \\
\text { de topo }\end{array}$ & $\begin{array}{c}\text { Isalterito } \\
\text { Micáceo } \\
\text { de topo }\end{array}$ & $\begin{array}{c}\text { Isalterito } \\
\text { Micáceo } \\
\text { de topo }\end{array}$ & $\begin{array}{l}\text { Isalterito } \\
\text { Oxidado }\end{array}$ & $\begin{array}{l}\text { Aloterita } \\
\text { Base }\end{array}$ & $\begin{array}{c}\text { Aloterita } \\
\text { Base }\end{array}$ & $\begin{array}{l}\text { Aloterita } \\
\text { Base }\end{array}$ & $\begin{array}{c}\text { Aloterita } \\
\text { Base }\end{array}$ \\
\hline Prof. (m) & 167,35 & 166,25 & 164,9 & 164,9 & 161 & 161 & 157,1 & 152,9 & 145 & 140,2 & 132 & 129,8 & 126,8 & 120,9 & 116,3 & 114,2 & 106,1 & 102 \\
\hline Análise & 1 & 2 & 3 & 4 & 5 & 6 & 7 & 8 & 9 & 10 & 11 & 12 & 13 & 14 & 15 & 16 & 17 & 18 \\
\hline $\mathrm{La}$ & 772,9 & 354,2 & 390,5 & 235,7 & 319,0 & 273,3 & 435,1 & $1.466,0$ & 704,9 & $7.247,9$ & 533,6 & $1.841,3$ & $12.431,7$ & $8.936,7$ & $4.738,1$ & $5.242,4$ & $3.882,0$ & $3.389,4$ \\
\hline $\mathrm{Ce}$ & $1.493,4$ & 754,3 & 864,4 & 465,0 & 737,9 & 557,5 & 906,6 & $2.846,3$ & $1.358,7$ & $12.181,5$ & 992,1 & $3.584,2$ & $20.614,9$ & $15.929,7$ & $8.890,2$ & $10.951,7$ & $8.128,8$ & $6.477,3$ \\
\hline $\operatorname{Pr}$ & 160,9 & 82,2 & 98,9 & 48,9 & 88,4 & 61,1 & 101,2 & 304,3 & 149,2 & $1.120,0$ & 101,7 & 372,2 & $2.106,5$ & $1.755,5$ & 923,4 & $1.287,3$ & 882,4 & 694,0 \\
\hline $\mathrm{Nd}$ & 598,4 & 321,9 & 389,6 & 178,5 & 361,6 & 234,4 & 391,9 & $1.119,7$ & 564,5 & $3.604,2$ & 360,4 & $1.370,5$ & $6.520,2$ & $5.528,7$ & $3.440,9$ & $4.549,0$ & $3.405,9$ & $2.636,1$ \\
\hline Sm & 82,2 & 51,0 & 58,7 & 24,2 & 60,4 & 36,2 & 59,1 & 149,0 & 83,4 & 440,6 & 50,9 & 196,0 & 786,2 & 818,7 & 524,1 & 700,4 & 495,1 & 423,3 \\
\hline $\mathrm{Eu}$ & 20,5 & 14,0 & 15,7 & 5,9 & 16,1 & 9,7 & 15,2 & 37,3 & 20,9 & 114,4 & 13,0 & 50,3 & 157,5 & 218,3 & 137,8 & 187,6 & 135,5 & 119,8 \\
\hline Gd & 43,9 & 31,7 & 35,3 & 11,8 & 36,7 & 22,6 & 34,6 & 76,1 & 48,3 & 223,6 & 27,5 & 105,9 & 255,9 & 492,2 & 302,0 & 420,7 & 299,7 & 275,5 \\
\hline $\mathrm{Tb}$ & 4,6 & 3,8 & 4,1 & 1,2 & 4,2 & 2,6 & 3,8 & 7,9 & 5,0 & 24,5 & 3,0 & 11,0 & 19,4 & 53,8 & 33,5 & 47,8 & 33,7 & 31,3 \\
\hline Dy & 18,9 & 16,6 & 19,1 & 4,6 & 17,7 & 11,0 & 15,8 & 32,1 & 22,2 & 99,6 & 11,8 & 47,4 & 56,5 & 239,9 & 140,0 & 212,3 & 141,7 & 134,9 \\
\hline Ho & 2,6 & 2,6 & 3,2 & 0,6 & 2,5 & 1,5 & 2,2 & 4,3 & 3,1 & 13,0 & 1,5 & 6,3 & 7,0 & 35,5 & 18,7 & 31,0 & 19,1 & 18,9 \\
\hline $\mathrm{Er}$ & 4,7 & 5,1 & 6,6 & 1,2 & 5,0 & 3,0 & 4,1 & 7,8 & 5,9 & 23,2 & 3,0 & 11,8 & 12,5 & 75,6 & 36,2 & 65,2 & 39,1 & 38,5 \\
\hline $\mathrm{Tm}$ & 0,4 & 0,6 & 0,7 & 0,1 & 0,5 & 0,3 & 0,4 & 0,7 & 0,5 & 2,1 & 0,3 & 1,1 & 1,2 & 8,3 & 3,5 & 7,0 & 4,0 & 3,9 \\
\hline $\mathrm{Yb}$ & 2,1 & 2,8 & 3,2 & 0,6 & 2,4 & 1,4 & 1,8 & 3,1 & 2,7 & 9,2 & 1,4 & 5,1 & 6,3 & 38,5 & 14,6 & 35,2 & 18,2 & 17,1 \\
\hline $\mathrm{Lu}$ & 0,2 & 0,4 & 0,4 & 0,1 & 0,3 & 0,2 & 0,2 & 0,4 & 0,4 & 0,9 & 0,1 & 0,5 & 0,6 & 5,1 & 1,8 & 4,7 & 2,2 & 2,0 \\
\hline$\Sigma$ REE & 3.206 & 1.641 & 1.890 & 978 & 1.653 & 1.215 & 1.972 & 6.055 & 2.970 & 25.105 & 2.101 & 7.604 & 42.976 & 34.136 & 19.205 & 23.742 & 17.487 & 14.262 \\
\hline $\mathrm{Hf}$ & 5 & 2 & 8 & 4 & 18 & 9 & 8 & 21 & 6 & 35 & 7 & 14 & 17 & 25 & 57 & 45 & 30 & 58 \\
\hline $\mathrm{Ta}$ & 37 & 27 & 37 & 25 & 22 & 14 & 39 & 58 & 43 & 191 & 36 & 68 & 82 & 245 & 243 & 503 & 256 & 189 \\
\hline Th & 44 & 79 & 49 & 17 & 109 & 36 & 70 & 106 & 44 & 276 & 41 & 180 & 877 & 1406 & 749 & 1128 & 948 & 603 \\
\hline $\mathrm{U}$ & 6 & 59 & 13 & 2 & 20 & 5 & 9 & 23 & 10 & 111 & 6 & 49 & 84 & 729 & 395 & 478 & 163 & 284 \\
\hline
\end{tabular}


Análises químicas de rocha total II.

\begin{tabular}{|c|c|c|c|c|c|c|c|c|c|c|c|c|c|c|c|c|c|c|}
\hline Rocha & Beb. & Beb. & Beb. & Beb. & Beb. & Beb. & - & - & - & - & - & - & Beb. & Beb. & Beb. & Beb. & $\begin{array}{c}\text { Pirox. } \\
\text { Beb. }\end{array}$ & Beb. \\
\hline Intemp. & $\begin{array}{l}\text { Aloterita } \\
\text { Base }\end{array}$ & $\begin{array}{l}\text { Aloterita } \\
\text { Base }\end{array}$ & $\begin{array}{l}\text { Aloterita } \\
\text { Base }\end{array}$ & $\begin{array}{c}\text { Aloterita } \\
\text { Base }\end{array}$ & $\begin{array}{l}\text { Aloterita } \\
\text { Base }\end{array}$ & $\begin{array}{l}\text { Aloterita } \\
\text { Base }\end{array}$ & $\begin{array}{l}\text { Aloterita } \\
\text { Topo }\end{array}$ & $\begin{array}{l}\text { Aloterita } \\
\text { Topo }\end{array}$ & $\begin{array}{l}\text { Aloterita } \\
\text { Topo }\end{array}$ & $\begin{array}{c}\text { Aloterita } \\
\text { Topo }\end{array}$ & $\begin{array}{l}\text { Aloterita } \\
\text { Topo }\end{array}$ & $\begin{array}{c}\text { Aloterita } \\
\text { Topo }\end{array}$ & $\begin{array}{l}\text { Rocha } \\
\text { Fresca }\end{array}$ & $\begin{array}{l}\text { Rocha } \\
\text { Fresca }\end{array}$ & $\begin{array}{c}\text { Rocha } \\
\text { Alterada }\end{array}$ & $\begin{array}{c}\text { Rocha } \\
\text { Alterada }\end{array}$ & $\begin{array}{l}\text { Rocha } \\
\text { Fresca }\end{array}$ & $\begin{array}{c}\text { Aloterita } \\
\text { de base }\end{array}$ \\
\hline Prof. (m) & 93,5 & 88,6 & 87,85 & 83,45 & 80,1 & 71 & 57 & 51,5 & 43,72 & 28,4 & 15,3 & 5,8 & 106,6 & 106,6 & 106,5 & 106,5 & 101,4 & 36,6 \\
\hline Análise & 19 & 20 & 21 & 22 & 23 & 24 & 25 & 26 & 27 & 28 & 29 & 30 & 31 & 32 & 33 & 34 & 35 & 36 \\
\hline $\mathrm{SiO}_{2}$ & 3,98 & 5,88 & 6,28 & 6,22 & 11,62 & 5,75 & 28,56 & 29,82 & 30,17 & 29,14 & 18,87 & 13,33 & 17,20 & 14,43 & 10,75 & 20,94 & 42,07 & 7,21 \\
\hline $\mathrm{TiO}_{2}$ & 28,21 & 19,02 & 21,01 & 18,99 & 7,78 & 18,25 & 7,53 & 6,70 & 6,04 & 7,53 & 9,14 & 9,16 & 21,08 & 19,71 & 11,28 & 11,91 & 5,36 & 39,04 \\
\hline $\mathrm{Al}_{2} \mathrm{O}_{3}$ & 3,73 & 8,05 & 8,65 & 7,45 & 9,23 & 10,28 & 27,28 & 28,67 & 29,03 & 29,07 & 32,59 & 34,84 & 1,79 & 0,94 & 0,39 & 3,68 & 0,68 & 12,85 \\
\hline $\mathrm{Fe}_{2} \mathrm{O}_{3}$ & 46,14 & 44,50 & 42,93 & 47,63 & 31,43 & 46,12 & 19,37 & 17,83 & 18,58 & 17,99 & 20,54 & 21,53 & 22,12 & 18,21 & 11,44 & 16,49 & 12,73 & 14,35 \\
\hline $\mathrm{MnO}$ & 1,06 & 1,60 & 1,03 & 1,28 & 7,24 & 0,44 & 0,14 & 0,12 & 0,11 & 0,10 & 0,11 & 0,10 & 0,25 & 0,22 & 0,57 & 0,26 & 0,15 & 0,38 \\
\hline $\mathrm{MgO}$ & 2,19 & 2,33 & 1,28 & 3,75 & 0,88 & 1,13 & 0,29 & 0,27 & 0,21 & 0,23 & 0,30 & 0,24 & 15,59 & 12,65 & 16,14 & 15,52 & 13,55 & 0,82 \\
\hline $\mathrm{CaO}$ & 0,54 & 0,53 & 0,54 & 0,37 & 0,47 & 0,99 & 0,27 & 0,24 & 0,18 & 0,14 & 0,07 & 0,06 & 13,90 & 20,48 & 17,92 & 11,32 & 23,16 & 0,42 \\
\hline $\mathrm{Na}_{2} \mathrm{O}$ & 0,03 & 0,06 & 0,03 & 0,03 & 0,06 & 0,04 & 0,04 & 0,04 & 0,03 & 0,03 & 0,04 & 0,03 & 0,18 & 0,23 & 0,29 & 0,38 & 0,37 & 0,06 \\
\hline $\mathrm{K}_{2} \mathrm{O}$ & 0,03 & 0,05 & 0,03 & 0,02 & 0,05 & 0,03 & 0,19 & 0,17 & 0,09 & 0,03 & 0,05 & 0,04 & 2,35 & 1,93 & 1,86 & 4,32 & 0,33 & 0,05 \\
\hline $\mathrm{P}_{2} \mathrm{O}_{5}$ & 3,64 & 4,00 & 4,12 & 2,90 & 4,81 & 4,84 & 1,85 & 1,61 & 1,42 & 1,35 & 0,75 & 0,70 & 0,22 & 5,13 & 2,36 & 5,26 & 1,19 & 5,78 \\
\hline $\mathrm{BaO}$ & 0,20 & 0,50 & 0,32 & 0,32 & 1,39 & 0,32 & 0,24 & 0,21 & 0,18 & 0,17 & 0,09 & 0,08 & 0,09 & 0,08 & 0,77 & 0,51 & 0,05 & 0,93 \\
\hline $\mathrm{SrO}$ & 0,46 & 0,74 & 0,61 & 0,51 & 0,69 & 0,55 & 0,28 & 0,24 & 0,22 & 0,21 & 0,10 & 0,09 & 0,15 & 0,24 & 0,51 & 0,53 & 0,13 & 0,63 \\
\hline LOI & 5,80 & 8,11 & 8,31 & 7,04 & 11,85 & 8,52 & 13,30 & 13,70 & 13,70 & 13,45 & 16,35 & 19,00 & 4,34 & 4,61 & 23,20 & 7,98 & 1,16 & 10,45 \\
\hline TOTAL & 96,04 & 95,40 & 95,17 & 96,55 & 87,51 & 97,28 & 99,35 & 99,65 & 99,99 & 99,47 & 99,03 & 99,22 & 99,27 & 98,86 & 97,49 & 99,12 & 100,95 & 92,99 \\
\hline $\mathrm{S}$ & $<0,01$ & 0,01 & $<0,01$ & 0,01 & 0,01 & 0,04 & 0,04 & 0,04 & 0,04 & 0,04 & 0,02 & 0,01 & 0,05 & $<0,01$ & 0,12 & 0,01 & 0,01 & 0,01 \\
\hline V & 908,7 & 873,0 & 828,3 & $1.044,3$ & 658,7 & 765,9 & 699,8 & 635,5 & 653,4 & 646,2 & 762,3 & 805,1 & 376,7 & 342,8 & 374,9 & 349,9 & 217,8 & 617,7 \\
\hline $\mathrm{Cr}$ & 321,5 & 306,9 & 277,7 & 336,1 & 233,8 & 277,7 & 350,8 & 321,5 & 321,5 & 321,5 & 350,8 & 423,8 & 175,4 & 146,2 & 116,9 & 131,5 & 58,5 & 233,8 \\
\hline $\mathrm{Ni}$ & 376,7 & 418,7 & 347,4 & 342,3 & $1.261,0$ & 202,3 & 114,5 & 101,8 & 94,2 & 73,8 & 76,4 & 67,4 & 395,7 & 272,3 & 196,0 & 290,1 & 66,2 & 166,7 \\
\hline $\mathrm{Rb}$ & 1,9 & 2,7 & 2,1 & 1,5 & 2,2 & 1,5 & 17,4 & 12,4 & 6,1 & 1,6 & 1,7 & 1,5 & 77,5 & 58,2 & 75,9 & 161,9 & 8,3 & 2,2 \\
\hline $\mathrm{Sr}$ & $4.813,2$ & $7.935,2$ & $6.303,3$ & $5.191,6$ & $7.663,2$ & $5.463,6$ & $2.767,3$ & $2.347,5$ & $2.134,6$ & $2.010,4$ & $1.031,2$ & 851,5 & $1.496,0$ & $2.258,8$ & $4.966,9$ & $5.203,4$ & $1.188,5$ & $6.729,0$ \\
\hline $\mathrm{Y}$ & 383,5 & 466,1 & 386,0 & 266,7 & $1.269,9$ & 345,4 & 198,1 & 178,4 & 166,4 & 120,3 & 79,5 & 71,7 & 122,4 & 167,0 & 74,8 & 146,0 & 45,6 & 831,8 \\
\hline $\mathrm{Zr}$ & $1.398,1$ & $1.999,2$ & $1.134,7$ & $2.134,3$ & 826,7 & $1.306,2$ & $1.648,0$ & $3.687,7$ & $1.587,2$ & $1.648,0$ & $1.688,5$ & $1.675,0$ & 428,2 & 711,9 & 258,0 & 551,1 & 283,7 & 926,6 \\
\hline $\mathrm{Nb}$ & $4.434,6$ & $5.149,8$ & $5.435,9$ & $6.151,2$ & $4.005,4$ & $2.746,6$ & $1.088,6$ & $1.180,2$ & 844,0 & 965,6 & 919,8 & $1.057,1$ & $1.278,9$ & $1.283,2$ & $1.407,6$ & 786,8 & 432,0 & $6.866,4$ \\
\hline $\mathrm{Ba}$ & $1.981,8$ & $5.325,7$ & $3.316,0$ & $3.450,0$ & $13.900,0$ & $3.237,9$ & $2.478,6$ & $2.149,3$ & $1.864,6$ & $1.792,0$ & 923,3 & 755,9 & 782,7 & 532,6 & $7.659,2$ & $5.124,7$ & 284,7 & $9.222,3$ \\
\hline
\end{tabular}


Análises químicas de rocha total II (continuação).

\begin{tabular}{|c|c|c|c|c|c|c|c|c|c|c|c|c|c|c|c|c|c|c|}
\hline Rocha & Beb. & Beb. & Beb. & Beb. & Beb. & Beb. & - & - & - & - & - & - & Beb. & Beb. & Beb. & Beb. & $\begin{array}{l}\text { Pirox. } \\
\text { Beb. }\end{array}$ & Beb. \\
\hline Intemp. & $\begin{array}{c}\text { Aloterita } \\
\text { Base }\end{array}$ & $\begin{array}{l}\text { Aloterita } \\
\text { Base }\end{array}$ & $\begin{array}{c}\text { Aloterita } \\
\text { Base }\end{array}$ & $\begin{array}{l}\text { Aloterita } \\
\text { Base }\end{array}$ & $\begin{array}{l}\text { Aloterita } \\
\text { Base }\end{array}$ & $\begin{array}{l}\text { Aloterita } \\
\text { Base }\end{array}$ & $\begin{array}{c}\text { Aloterita } \\
\text { Topo }\end{array}$ & $\begin{array}{l}\text { Aloterita } \\
\text { Topo }\end{array}$ & $\begin{array}{c}\text { Aloterita } \\
\text { Topo }\end{array}$ & $\begin{array}{l}\text { Aloterita } \\
\text { Topo }\end{array}$ & $\begin{array}{c}\text { Aloterita } \\
\text { Topo }\end{array}$ & $\begin{array}{c}\text { Aloterita } \\
\text { Topo }\end{array}$ & $\begin{array}{l}\text { Rocha } \\
\text { Fresca }\end{array}$ & $\begin{array}{l}\text { Rocha } \\
\text { Fresca }\end{array}$ & $\begin{array}{l}\text { Rocha } \\
\text { Alterada }\end{array}$ & $\begin{array}{l}\text { Rocha } \\
\text { Alterada }\end{array}$ & $\begin{array}{l}\text { Rocha } \\
\text { Fresca }\end{array}$ & $\begin{array}{l}\text { Aloterita } \\
\text { de base }\end{array}$ \\
\hline Prof. (m) & 93,5 & 88,6 & 87,85 & 83,45 & 80,1 & 71 & 57 & 51,5 & 43,72 & 28,4 & 15,3 & 5,8 & 106,6 & 106,6 & 106,5 & 106,5 & 101,4 & 36,6 \\
\hline Análise & 19 & 20 & 21 & 22 & 23 & 24 & 25 & 26 & 27 & 28 & 29 & 30 & 31 & 32 & 33 & 34 & 35 & 36 \\
\hline $\mathrm{La}$ & $3.776,4$ & $3.506,7$ & $3.459,8$ & $2.292,8$ & $12.314,4$ & $2.638,8$ & $1.012,1$ & 907,7 & 886,6 & 947,6 & 805,7 & 737,7 & $2.152,1$ & $2.322,1$ & $2.697,4$ & $1.366,3$ & 546,5 & $8.561,4$ \\
\hline $\mathrm{Ce}$ & $7.226,9$ & $6.125,9$ & $6.957,5$ & $4.205,0$ & $16.749,6$ & $5.095,2$ & $1.862,4$ & $1.698,4$ & $1.581,3$ & $1.733,5$ & $1.505,1$ & $1.593,0$ & $4.345,5$ & $4.439,2$ & $5.095,2$ & $2.682,3$ & 893,7 & $14.055,6$ \\
\hline Pr & 729,1 & 649,5 & 710,4 & 433,0 & $1.521,4$ & 548,9 & 200,1 & 191,9 & 170,9 & 206,6 & 133,4 & 107,6 & 461,1 & 475,1 & 534,8 & 296,1 & 85,7 & $1.638,4$ \\
\hline $\mathrm{Nd}$ & $2.589,4$ & $2.332,8$ & $2.472,8$ & $1.557,1$ & $4.887,2$ & $2.000,4$ & 744,2 & 729,0 & 645,0 & 821,1 & 431,6 & 345,3 & $1.702,9$ & $1.743,8$ & $1.848,7$ & $1.130,2$ & 306,8 & $5.727,0$ \\
\hline $\mathrm{Sm}$ & 381,5 & 335,1 & 351,4 & 220,3 & 613,4 & 281,8 & 114,5 & 113,4 & 97,8 & 127,0 & 58,4 & 45,5 & 245,8 & 266,7 & 184,4 & 174,5 & 47,3 & 745,6 \\
\hline $\mathrm{Eu}$ & 104,8 & 89,9 & 91,6 & 59,5 & 155,7 & 80,9 & 30,1 & 30,5 & 25,7 & 31,3 & 14,5 & 11,6 & 63,3 & 67,5 & 41,2 & 44,9 & 13,3 & 192,2 \\
\hline $\mathrm{Gd}$ & 240,9 & 212,7 & 205,7 & 131,4 & 342,3 & 185,6 & 79,0 & 77,9 & 67,4 & 70,2 & 34,0 & 27,4 & 136,6 & 147,5 & 80,6 & 109,4 & 33,9 & 457,6 \\
\hline $\mathrm{Tb}$ & 28,0 & 24,4 & 23,1 & 14,8 & 40,9 & 20,1 & 9,5 & 10,0 & 8,0 & 8,1 & 4,1 & 3,5 & 14,0 & 15,9 & 7,4 & 12,2 & 4,2 & 51,7 \\
\hline Dy & 114,4 & 112,2 & 97,6 & 66,9 & 211,2 & 87,1 & 46,3 & 52,2 & 38,1 & 36,6 & 19,7 & 16,5 & 54,1 & 63,2 & 28,0 & 48,7 & 16,1 & 211,8 \\
\hline Но & 16,2 & 17,0 & 14,5 & 9,8 & 41,8 & 14,7 & 8,3 & 8,2 & 6,0 & 5,4 & 3,2 & 2,8 & 6,9 & 8,2 & 3,3 & 6,2 & 2,2 & 32,1 \\
\hline $\mathrm{Er}$ & 32,2 & 37,2 & 31,4 & 20,8 & 107,5 & 29,8 & 19,2 & 17,2 & 13,7 & 11,5 & 8,0 & 7,0 & 11,4 & 14,4 & 6,1 & 12,0 & 4,1 & 75,0 \\
\hline $\mathrm{Tm}$ & 3,2 & 4,1 & 3,4 & 2,4 & 12,8 & 2,8 & 2,1 & 1,9 & 1,7 & 1,4 & 1,0 & 0,9 & 1,0 & 1,3 & 0,6 & 1,0 & 0,4 & 8,6 \\
\hline $\mathrm{Yb}$ & 14,5 & 20,3 & 17,1 & 12,2 & 68,5 & 11,3 & 10,3 & 9,6 & 9,2 & 7,6 & 6,3 & 5,9 & 4,1 & 5,5 & 2,6 & 4,7 & 1,8 & 41,1 \\
\hline $\mathrm{Lu}$ & 1,8 & 2,8 & 2,3 & 1,8 & 9,0 & 1,1 & 1,4 & 1,3 & 1,3 & 1,1 & 0,9 & 0,9 & 0,4 & 0,6 & 0,3 & 0,6 & 0,2 & 4,1 \\
\hline$\Sigma$ REE & 15.259 & 13.471 & 14.439 & 9.028 & 37.076 & 10.999 & 4.139 & 3.849 & 3.553 & 4.009 & 3.026 & 2.906 & 9.199 & 9.571 & 10.531 & 5.889 & 1.956 & 31.802 \\
\hline $\mathrm{Hf}$ & 45 & 49 & 32 & 50 & 22 & 36 & 36 & 71 & 36 & 38 & 38 & 38 & 13 & 19 & 8 & 15 & 11 & 30 \\
\hline $\mathrm{Ta}$ & 164 & 165 & 151 & 197 & 172 & 114 & 44 & 42 & 35 & 39 & 38 & 42 & 110 & 109 & 65 & 54 & 18 & 219 \\
\hline Th & 278 & 578 & 708 & 804 & 832 & 254 & 124 & 129 & 104 & 125 & 113 & 120 & 148 & 138 & 78 & 61 & 20 & 352 \\
\hline $\mathrm{U}$ & 95 & 53 & 54 & 40 & 67 & 46 & 18 & 17 & 13 & 15 & 15 & 17 & 18 & 18 & 11 & 8 & 7 & 155 \\
\hline
\end{tabular}


Análises EDS de Apatita (I).

\begin{tabular}{|c|c|c|c|c|c|c|c|c|c|c|c|c|c|c|c|c|}
\hline Rocha & Beb. & Beb. & Beb. & Beb. & Beb. & Beb. & Beb. & Beb. & Beb. & Beb. & Beb. & Beb. & Beb. & Carb. & Carb. & Carb. \\
\hline Intemp. & $\begin{array}{l}\text { rocha } \\
\text { fresca }\end{array}$ & $\begin{array}{l}\text { rocha } \\
\text { fresca }\end{array}$ & $\begin{array}{l}\text { rocha } \\
\text { fresca }\end{array}$ & $\begin{array}{l}\text { rocha } \\
\text { fresca }\end{array}$ & $\begin{array}{l}\text { rocha } \\
\text { fresca }\end{array}$ & $\begin{array}{l}\text { rocha } \\
\text { fresca }\end{array}$ & $\begin{array}{l}\text { rocha } \\
\text { fresca }\end{array}$ & $\begin{array}{l}\text { rocha } \\
\text { fresca }\end{array}$ & $\begin{array}{l}\text { rocha } \\
\text { fresca }\end{array}$ & $\begin{array}{l}\text { rocha } \\
\text { fresca }\end{array}$ & $\begin{array}{l}\text { rocha } \\
\text { fresca }\end{array}$ & $\begin{array}{l}\text { rocha } \\
\text { fresca }\end{array}$ & $\begin{array}{l}\text { rocha } \\
\text { fresca }\end{array}$ & $\begin{array}{l}\text { rocha } \\
\text { fresca }\end{array}$ & $\begin{array}{l}\text { rocha } \\
\text { fresca }\end{array}$ & $\begin{array}{l}\text { rocha } \\
\text { fresca }\end{array}$ \\
\hline Prof. & 106,5 & 106,50 & 106,50 & 106,5 & 106,50 & 106,50 & 106,5 & 157,2 & 106,6 & 106,5 & 106,5 & 106,5 & 106,50 & 166,50 & 166,50 & 166,5 \\
\hline Análise & 1 & 2 & 3 & 4 & 5 & 6 & 7 & 8 & 9 & 10 & 11 & 12 & 13 & 14 & 15 & 16 \\
\hline $\mathrm{SiO}_{2}$ & n.d. & n.d. & n.d. & n.d. & 0,47 & 0,42 & n.d. & n.d. & n.d. & n.d. & n.d. & n.d. & n.d. & n.d. & n.d. & n.d. \\
\hline $\mathrm{FeO}$ & n.d. & 0,69 & 0,82 & n.d. & 0,60 & 0,94 & n.d. & n.d. & n.d. & n.d. & n.d. & n.d. & 9,41 & 0,87 & 2,28 & n.d. \\
\hline $\mathrm{MgO}$ & 0,53 & 0,50 & 0,42 & n.d. & 0,40 & 0,54 & n.d. & n.d. & n.d. & 0,58 & n.d. & 0,45 & n.d. & n.d. & n.d. & n.d. \\
\hline $\mathrm{CaO}$ & 47,73 & 50,85 & 51,66 & 50,16 & 50,62 & 51,23 & 46,84 & 52,21 & 40,06 & 54,78 & 55,46 & 54,77 & 49,37 & 51,39 & 54,77 & 52,75 \\
\hline $\mathrm{BaO}$ & n.d. & n.d. & n.d. & n.d. & n.d. & n.d. & 0,79 & n.d. & n.d. & n.d. & n.d. & n.d. & n.d. & n.d. & n.d. & n.d. \\
\hline $\mathrm{SrO}$ & 3,57 & 3,70 & n.d. & n.d. & 3,56 & 3,75 & n.d. & 2,84 & 4,94 & n.d. & 1,46 & 0,83 & n.d. & 3,73 & n.d. & 2,69 \\
\hline $\mathrm{Na}_{2} \mathrm{O}$ & 3,80 & 2,54 & 1,98 & 0,82 & 1,87 & 2,02 & 3,45 & n.d. & 3,56 & 4,36 & 4,45 & 4,06 & 3,86 & 2,21 & 2,04 & 3,15 \\
\hline $\mathrm{P}_{2} \mathrm{O}_{5}$ & 38,67 & 38,37 & 40,77 & 37,22 & 37,69 & 37,51 & 36,53 & 43,12 & 36,56 & 38,51 & 36,89 & 38,13 & 34,62 & 38,45 & 37,77 & 37,89 \\
\hline $\mathrm{La}_{2} \mathrm{O}_{3}$ & n.d. & n.d. & n.d. & 2,29 & 0,18 & 0,04 & 2,57 & n.d. & 3,03 & n.d. & n.d. & n.d. & n.d. & n.d. & n.d. & n.d. \\
\hline $\mathrm{Ce}_{2} \mathrm{O}_{3}$ & 2,63 & 1,52 & 2,46 & 5,64 & 1,97 & 1,26 & 5,30 & n.d. & 6,50 & n.d. & n.d. & n.d. & n.d. & n.d. & n.d. & n.d. \\
\hline $\mathrm{Pr}_{2} \mathrm{O}_{3}$ & n.d. & n.d. & n.d. & n.d. & n.d. & n.d. & n.d. & n.d. & n.d. & n.d. & n.d. & n.d. & n.d. & n.d. & n.d. & n.d. \\
\hline $\mathrm{Nd}_{2} \mathrm{O}_{3}$ & 1,35 & n.d. & n.d. & 2,18 & 0,86 & 0,44 & 2,05 & n.d. & 2,97 & n.d. & n.d. & n.d. & n.d. & n.d. & n.d. & n.d. \\
\hline $\mathrm{SO}_{3}$ & n.d. & n.d. & n.d. & n.d. & n.d. & n.d. & n.d. & n.d. & n.d. & n.d. & n.d. & n.d. & n.d. & n.d. & n.d. & n.d. \\
\hline F & n.d. & n.d. & n.d. & n.d. & n.d. & n.d. & 1,55 & n.d. & 1,41 & n.d. & n.d. & n.d. & n.d. & 2,85 & 2,13 & 3,35 \\
\hline $\mathrm{Cl}$ & n.d. & n.d. & n.d. & n.d. & n.d. & n.d. & n.d. & n.d. & n.d. & n.d. & n.d. & n.d. & n.d. & n.d. & n.d. & n.d. \\
\hline H & 1,73 & 1,74 & 1,79 & 1,69 & 1,73 & 1,73 & 0,95 & 1,82 & 0,97 & 1,77 & 1,74 & 1,76 & 1,68 & 0,41 & 0,75 & 0,17 \\
\hline TOTAL & 100,01 & 99,91 & 99,90 & 100,00 & 99,94 & 99,88 & 100,02 & 99,99 & 100,01 & 100,00 & 100,00 & 100,00 & 98,94 & 99,91 & 99,75 & 100,00 \\
\hline $\mathrm{Si}$ & - & - & - & - & 0,082 & 0,073 & - & - & - & - & - & - & - & - & - & - \\
\hline $\mathrm{Fe} 2$ & - & 0,099 & 0,115 & - & 0,087 & 0,136 & - & - & - & - & - & - & 1,404 & 0,124 & 0,325 & - \\
\hline $\mathrm{Mg}$ & 0,137 & 0,129 & 0,106 & - & 0,104 & 0,140 & - & - & - & 0,145 & - & 0,113 & - & - & - & - \\
\hline $\mathrm{Ca}$ & 8,866 & 9,394 & 9,294 & 9,512 & 9,412 & 9,509 & 8,939 & 9,224 & 7,832 & 9,921 & 10,231 & 9,976 & 9,436 & 9,391 & 9,981 & 9,620 \\
\hline $\mathrm{Ba}$ & - & - & - & - & - & - & 0,055 & - & - & - & - & - & - & - & - & - \\
\hline $\mathrm{Sr}$ & 0,359 & 0,370 & - & - & 0,358 & 0,377 & & 0,271 & 0,523 & - & 0,145 & 0,082 & - & 0,369 & - & 0,266 \\
\hline $\mathrm{Na}$ & 1,278 & 0,848 & 0,646 & 0,280 & 0,628 & 0,680 & 1,190 & - & 1,261 & 1,428 & 1,485 & 1,339 & 1,336 & 0,731 & 0,674 & 1,039 \\
\hline$P$ & 5,676 & 5,602 & 5,796 & 5,578 & 5,537 & 5,502 & 5,509 & 6,020 & 5,648 & 5,511 & 5,378 & 5,487 & 5,228 & 5,553 & 5,439 & 5,460 \\
\hline $\mathrm{La}$ & - & - & - & 0,150 & 0,011 & 0,003 & 0,169 & - & 0,204 & - & - & - & - & - & - & - \\
\hline $\mathrm{Ce}$ & 0,167 & 0,096 & 0,151 & 0,366 & 0,125 & 0,080 & 0,346 & - & 0,434 & - & - & - & - & - & - & - \\
\hline $\operatorname{Pr}$ & - & - & - & - & - & - & - & - & - & - & - & - & - & - & - & - \\
\hline $\mathrm{Nd}$ & 0,083 & - & - & 0,138 & 0,054 & 0,027 & 0,130 & - & 0,194 & - & - & - & - & - & - & - \\
\hline S & - & - & - & - & - & - & - & - & - & - & - & - & - & - & - & - \\
\hline Cátions & 16,567 & 16,538 & 16,107 & 16,023 & 16,399 & 16,526 & 16,339 & 15,516 & 16,095 & 17,004 & 17,240 & 16,997 & 17,405 & 16,168 & 16,419 & 16,386 \\
\hline
\end{tabular}

Análises 1-16: apatita metassomática. 
Análises EDS de Apatita (II).

\begin{tabular}{|c|c|c|c|c|c|c|c|c|c|c|c|c|c|c|c|c|}
\hline Rocha & Beb. & Beb. & Beb. & Beb. & Beb. & Beb. & Beb. & Beb. & Beb. & Beb. & Beb. & Beb. & Beb. & Beb. & Beb. & Beb. \\
\hline Intemp. & $\begin{array}{l}\text { rocha } \\
\text { fresca }\end{array}$ & $\begin{array}{l}\text { rocha } \\
\text { fresca }\end{array}$ & $\begin{array}{l}\text { rocha } \\
\text { fresca }\end{array}$ & $\begin{array}{l}\text { rocha } \\
\text { fresca }\end{array}$ & $\begin{array}{l}\text { rocha } \\
\text { fresca }\end{array}$ & $\begin{array}{l}\text { rocha } \\
\text { fresca }\end{array}$ & $\begin{array}{l}\text { rocha } \\
\text { fresca }\end{array}$ & $\begin{array}{l}\text { rocha } \\
\text { fresca }\end{array}$ & $\begin{array}{l}\text { rocha } \\
\text { fresca }\end{array}$ & $\begin{array}{l}\text { rocha } \\
\text { fresca }\end{array}$ & $\begin{array}{l}\text { rocha } \\
\text { fresca }\end{array}$ & $\begin{array}{l}\text { rocha } \\
\text { fresca }\end{array}$ & $\begin{array}{l}\text { rocha } \\
\text { fresca }\end{array}$ & $\begin{array}{l}\text { rocha } \\
\text { fresca }\end{array}$ & $\begin{array}{l}\text { rocha } \\
\text { fresca }\end{array}$ & $\begin{array}{l}\text { rocha } \\
\text { fresca }\end{array}$ \\
\hline Prof. & 106,5 & 106,50 & 106,50 & 106,5 & 106,50 & 106,50 & 106,5 & 157,2 & 106,6 & 106,5 & 106,5 & 106,5 & 106,50 & 166,50 & 166,50 & 166,5 \\
\hline Análise & 17 & 18 & 19 & 20 & 21 & 22 & 23 & 24 & 25 & 26 & 27 & 28 & 29 & 30 & 31 & 32 \\
\hline $\mathrm{SiO}_{2}$ & n.d. & n.d. & n.d. & n.d. & n.d. & n.d. & n.d. & n.d. & n.d. & n.d. & n.d. & n.d. & n.d. & n.d. & n.d. & n.d. \\
\hline $\mathrm{FeO}$ & n.d. & n.d. & n.d. & n.d. & n.d. & n.d. & n.d. & n.d. & n.d. & n.d. & n.d. & n.d. & n.d. & n.d. & n.d. & n.d. \\
\hline $\mathrm{MgO}$ & n.d. & n.d. & n.d. & n.d. & 0,42 & n.d. & 0,59 & n.d. & 0,48 & n.d. & 0,43 & 0,43 & n.d. & 0,46 & n.d. & n.d. \\
\hline $\mathrm{CaO}$ & 48,65 & 51,27 & 54,00 & 46,03 & 53,33 & 49,39 & 54,85 & 46,91 & 55,34 & 54,68 & 55,23 & 54,83 & 53,99 & 55,00 & 54,14 & 54,71 \\
\hline $\mathrm{BaO}$ & n.d. & n.d. & n.d. & n.d. & n.d. & n.d. & n.d. & n.d. & n.d. & n.d. & n.d. & n.d. & n.d. & n.d. & n.d. & n.d. \\
\hline $\mathrm{SrO}$ & 1,58 & 1,50 & 1,32 & 2,18 & 1,57 & 1,74 & n.d. & 2,09 & n.d. & 1,42 & 1,01 & 0,86 & 1,80 & 1,01 & n.d. & n.d. \\
\hline $\mathrm{Na}_{2} \mathrm{O}$ & 4,25 & 4,38 & 4,17 & 3,89 & 4,38 & 4,51 & 4,34 & 3,95 & 3,89 & 4,51 & 3,70 & 3,43 & 3,20 & 3,98 & n.d. & n.d. \\
\hline $\mathrm{P}_{2} \mathrm{O}_{5}$ & 36,04 & 37,31 & 38,27 & 35,19 & 38,53 & 37,12 & 38,45 & 34,98 & 38,51 & 37,64 & 37,86 & 38,68 & 39,24 & 37,78 & 42,82 & 43,45 \\
\hline $\mathrm{La}_{2} \mathrm{O}_{3}$ & 2,86 & n.d. & n.d. & 3,26 & n.d. & n.d. & n.d. & 3,28 & n.d. & n.d. & n.d. & n.d. & n.d. & n.d. & n.d. & n.d. \\
\hline $\mathrm{Ce}_{2} \mathrm{O}_{3}$ & 4,93 & 3,82 & n.d. & 6,64 & n.d. & 5,53 & n.d. & 5,88 & n.d. & n.d. & n.d. & n.d. & n.d. & n.d. & n.d. & n.d. \\
\hline $\mathrm{Pr}_{2} \mathrm{O}_{3}$ & n.d. & n.d. & n.d. & n.d. & n.d. & n.d. & n.d. & n.d. & n.d. & n.d. & n.d. & n.d. & n.d. & n.d. & n.d. & n.d. \\
\hline $\mathrm{Nd}_{2} \mathrm{O}_{3}$ & n.d. & n.d. & n.d. & n.d. & n.d. & n.d. & n.d. & n.d. & n.d. & n.d. & n.d. & n.d. & n.d. & n.d. & n.d. & n.d. \\
\hline $\mathrm{SO}_{3}$ & n.d. & n.d. & n.d. & n.d. & n.d. & n.d. & n.d. & n.d. & n.d. & n.d. & n.d. & n.d. & n.d. & n.d. & n.d. & n.d. \\
\hline F & n.d. & n.d. & 0,93 & 2,20 & n.d. & n.d. & n.d. & 2,37 & n.d. & n.d. & n.d. & n.d. & n.d. & n.d. & 2,30 & n.d. \\
\hline $\mathrm{Cl}$ & n.d. & n.d. & n.d. & n.d. & n.d. & n.d. & n.d. & n.d. & n.d. & n.d. & n.d. & n.d. & n.d. & n.d. & n.d. & n.d. \\
\hline H & 1,68 & 1,72 & 1,33 & 0,62 & 1,76 & 1,71 & 1,77 & 0,54 & 1,77 & 1,75 & 1,76 & 1,77 & 1,77 & 1,76 & 0,75 & 1,84 \\
\hline TOTAL & 100,00 & 100,00 & 100,01 & 100,01 & 100,00 & 100,00 & 100,00 & 100,01 & 100,00 & 100,00 & 100,00 & 100,00 & 100,00 & 100,00 & 100,01 & 100,00 \\
\hline $\mathrm{Si}$ & - & - & - & - & - & - & - & - & - & - & - & - & - & - & - & - \\
\hline $\mathrm{Fe} 2$ & - & - & - & - & - & - & - & - & - & - & - & - & - & - & - & - \\
\hline $\mathrm{Mg}$ & - & - & - & - & 0,107 & - & 0,148 & - & 0,122 & - & 0,110 & 0,109 & - & 0,117 & - & - \\
\hline $\mathrm{Ca}$ & 9,302 & 9,565 & 9,835 & 8,895 & 9,714 & 9,296 & 9,936 & 9,048 & 10,022 & 10,032 & 10,084 & 9,944 & 9,794 & 10,049 & 9,452 & 9,554 \\
\hline $\mathrm{Ba}$ & - & - & - & - & - & - & - & - & - & - & - & - & - & - & - & - \\
\hline $\mathrm{Sr}$ & 0,163 & 0,151 & 0,130 & 0,228 & 0,155 & 0,177 & - & 0,218 & - & 0,141 & 0,100 & 0,084 & 0,176 & 0,100 & - & - \\
\hline $\mathrm{Na}$ & 1,471 & 1,479 & 1,373 & 1,361 & 1,443 & 1,535 & 1,424 & 1,380 & 1,276 & 1,496 & 1,223 & 1,127 & 1,050 & 1,317 & - & - \\
\hline $\mathrm{P}$ & 5,445 & 5,500 & 5,508 & 5,374 & 5,545 & 5,520 & 5,504 & 5,331 & 5,510 & 5,456 & 5,462 & 5,543 & 5,625 & 5,454 & 5,908 & 5,995 \\
\hline $\mathrm{La}$ & 0,188 & - & - & 0,217 & - & - & - & 0,218 & - & - & - & - & - & - & - & - \\
\hline $\mathrm{Ce}$ & 0,322 & 0,244 & - & 0,439 & - & 0,356 & - & 0,387 & - & - & - & - & - & - & - & - \\
\hline $\operatorname{Pr}$ & - & - & - & - & - & - & - & - & - & - & - & - & - & - & - & - \\
\hline $\mathrm{Nd}$ & - & - & - & - & - & - & - & - & - & - & - & - & - & - & - & - \\
\hline S & - & - & - & - & - & - & - & - & - & - & - & - & - & - & - & - \\
\hline Cátions & 16,892 & 16,938 & 16,847 & 16,512 & 16,964 & 16,884 & 17,012 & 16,582 & 16,930 & 17,126 & 16,978 & 16,807 & 16,645 & 17,037 & 15,360 & 15,548 \\
\hline
\end{tabular}

-Análises 17-30: apatita metassomática, associada à dolomita. Análises 31-32: apatita ígnea no perovskita bebedourito. 
Análises EDS de Apatita (III).

\begin{tabular}{|c|c|c|c|c|c|c|c|c|c|c|c|c|c|c|c|c|}
\hline Rocha & Beb. & Beb. & Beb. & Beb. & Beb. & Beb. & Beb. & Beb. & Beb. & Beb. & Fosc. & Fosc. & Fosc. & Fosc. & Fosc. & Beb. \\
\hline \multirow{2}{*}{ Intemp. } & rocha & rocha & rocha & rocha & rocha & rocha & rocha & rocha & rocha & rocha & rocha & rocha & rocha & rocha & rocha & Isalt. Mic. \\
\hline & fresca & fresca & fresca & fresca & fresca & fresca & fresca & fresca & fresca & fresca & fresca & fresca & fresca & fresca & fresca & Tоро \\
\hline Prof. & 106,5 & 106,5 & 157,20 & 157,2 & 157,2 & 157,2 & 106,6 & 106,6 & 106,6 & 106,6 & 165,1 & 165,1 & 165,1 & 165,1 & 165,1 & 145,2 \\
\hline Análise & 33 & 34 & 35 & 36 & 37 & 38 & 39 & 40 & 41 & 42 & 43 & 44 & 45 & 46 & 47 & 48 \\
\hline $\mathrm{SiO}_{2}$ & n.d. & n.d. & n.d. & n.d. & n.d. & n.d. & n.d. & n.d. & n.d. & n.d. & n.d. & n.d. & n.d. & n.d. & n.d. & n.d. \\
\hline $\mathrm{FeO}$ & n.d. & n.d. & 4,21 & n.d. & n.d. & n.d. & n.d. & n.d. & n.d. & n.d. & n.d. & n.d. & n.d. & n.d. & n.d. & n.d. \\
\hline $\mathrm{MgO}$ & n.d. & n.d. & n.d. & n.d. & n.d. & n.d. & n.d. & n.d. & n.d. & n.d. & n.d. & n.d. & n.d. & n.d. & n.d. & n.d. \\
\hline $\mathrm{CaO}$ & 56,36 & 55,43 & 50,23 & 54,70 & 53,99 & 54,49 & 54,79 & 54,32 & 54,07 & 52,76 & 56,35 & 57,39 & 56,75 & 56,69 & 57,06 & 55,52 \\
\hline $\mathrm{BaO}$ & n.d. & n.d. & n.d. & n.d. & n.d. & n.d. & n.d. & n.d. & n.d. & n.d. & n.d. & n.d. & n.d. & n.d. & n.d. & n.d. \\
\hline $\mathrm{SrO}$ & n.d. & n.d. & n.d. & n.d. & n.d. & n.d. & n.d. & n.d. & n.d. & n.d. & n.d. & n.d. & n.d. & n.d. & n.d. & n.d. \\
\hline $\mathrm{Na}_{2} \mathrm{O}$ & n.d. & 0,20 & n.d. & n.d. & n.d. & n.d. & n.d. & n.d. & n.d. & 0,44 & n.d. & n.d. & n.d. & n.d. & n.d. & n.d. \\
\hline $\mathrm{P}_{2} \mathrm{O}_{5}$ & 40,93 & 40,59 & 38,97 & 42,32 & 43,04 & 43,67 & 42,77 & 43,24 & 42,82 & 42,27 & 41,83 & 40,80 & 41,43 & 41,49 & 41,13 & 42,66 \\
\hline $\mathrm{La}_{2} \mathrm{O}_{3}$ & n.d. & n.d. & n.d. & n.d. & n.d. & n.d. & n.d. & n.d. & n.d. & 0,37 & n.d. & n.d. & n.d. & n.d. & n.d. & n.d. \\
\hline $\mathrm{Ce}_{2} \mathrm{O}_{3}$ & n.d. & 1,03 & n.d. & n.d. & n.d. & n.d. & n.d. & n.d. & n.d. & 0,57 & n.d. & n.d. & n.d. & n.d. & n.d. & n.d. \\
\hline $\mathrm{Pr}_{2} \mathrm{O}_{3}$ & n.d. & n.d. & n.d. & n.d. & n.d. & n.d. & n.d. & n.d. & n.d. & n.d. & n.d. & n.d. & n.d. & n.d. & n.d. & n.d. \\
\hline $\mathrm{Nd}_{2} \mathrm{O}_{3}$ & n.d. & n.d. & n.d. & n.d. & n.d. & n.d. & n.d. & n.d. & n.d. & 0,62 & n.d. & n.d. & n.d. & n.d. & n.d. & n.d. \\
\hline $\mathrm{SO}_{3}$ & n.d. & n.d. & n.d. & n.d. & n.d. & n.d. & n.d. & n.d. & n.d. & n.d. & n.d. & n.d. & n.d. & n.d. & n.d. & n.d. \\
\hline $\mathrm{F}$ & 1,72 & 1,82 & 6,12 & 2,20 & 2,18 & n.d. & 1,14 & 1,15 & 2,44 & 2,22 & n.d. & n.d. & n.d. & n.d. & n.d. & n.d. \\
\hline $\mathrm{Cl}$ & n.d. & n.d. & n.d. & n.d. & n.d. & n.d. & 0,02 & 0,01 & n.d. & n.d. & n.d. & n.d. & n.d. & n.d. & n.d. & n.d. \\
\hline $\mathrm{H}$ & 1,00 & 0,94 & - & 0,79 & 0,81 & 1,84 & 1,29 & 1,29 & 0,68 & 0,77 & 1,82 & 1,81 & 1,81 & 1,81 & 1,81 & 1,83 \\
\hline TOTAL & 100,01 & 100,01 & 99,53 & 100,01 & 100,01 & 100,00 & 100,01 & 100,02 & 100,02 & 100,00 & 100,00 & 100,00 & 100,00 & 100,00 & 100,00 & 100,00 \\
\hline $\mathrm{Si}$ & - & - & - & - & - & - & - & - & - & - & - & - & - & - & - & - \\
\hline $\mathrm{Fe} 2$ & - & - & 0,588 & - & - & - & - & - & - & - & - & - & - & - & - & - \\
\hline $\mathrm{Mg}$ & - & - & - & - & - & - & - & - & - & - & - & - & - & - & - & - \\
\hline $\mathrm{Ca}$ & 9,982 & 9,876 & 9,000 & 9,586 & 9,414 & 9,499 & 9,592 & 9,478 & 9,438 & 9,302 & 9,951 & 10,210 & 10,051 & 10,036 & 10,127 & 9,747 \\
\hline $\mathrm{Ba}$ & - & - & - & - & - & - & - & - & - & - & - & - & - & - & - & - \\
\hline $\mathrm{Sr}$ & - & - & - & - & - & - & - & - & - & - & - & - & - & - & - & - \\
\hline $\mathrm{Na}$ & - & 0,064 & - & - & - & - & - & - & - & 0,139 & - & - & - & - & - & - \\
\hline $\mathrm{P}$ & 5,729 & 5,715 & 5,517 & 5,860 & 5,930 & 6,016 & 5,916 & 5,961 & 5,906 & 5,889 & 5,838 & 5,735 & 5,798 & 5,804 & 5,768 & 5,918 \\
\hline $\mathrm{La}$ & - & - & - & - & - & - & - & - & - & 0,022 & - & - & - & - & - & - \\
\hline $\mathrm{Ce}$ & - & 0,063 & - & - & - & - & - & - & - & 0,034 & - & - & - & - & - & - \\
\hline $\operatorname{Pr}$ & - & - & - & - & - & - & - & - & - & - & - & - & - & - & - & - \\
\hline $\mathrm{Nd}$ & - & - & - & - & - & - & - & - & - & 0,036 & - & - & - & - & - & - \\
\hline S & - & - & - & - & - & - & - & - & - & - & - & - & - & - & - & \\
\hline Cátions & 15,710 & 15,717 & 15,106 & 15,446 & 15,344 & 15,515 & 15,508 & 15,439 & 15,344 & 15,423 & 15,788 & 15,946 & 15,849 & 15,840 & 15,895 & 15,665 \\
\hline
\end{tabular}

Análises 33- 42 e 48: apatita ígnea no perovskita bebedourito. Análises 43-47: apatita no cumulado foscorítico. 
Análises EDS de Apatita (IV).

\begin{tabular}{|c|c|c|c|c|c|c|c|c|c|c|c|c|c|c|c|c|}
\hline Rocha & Beb. & Beb. & Beb. & Beb. & Beb. & Beb. & Beb. & Beb. & Beb. & Beb. & Beb. & Beb. & Beb. & Beb. & Beb. & Beb. \\
\hline Intemp. & $\begin{array}{l}\text { Isalt. Mic. } \\
\text { Base }\end{array}$ & $\begin{array}{l}\text { rocha } \\
\text { fresca }\end{array}$ & $\begin{array}{l}\text { rocha } \\
\text { fresca }\end{array}$ & $\begin{array}{l}\text { rocha } \\
\text { fresca }\end{array}$ & $\begin{array}{l}\text { rocha } \\
\text { fresca }\end{array}$ & $\begin{array}{l}\text { rocha } \\
\text { fresca }\end{array}$ & $\begin{array}{l}\text { Isalt. Mic. } \\
\text { Base }\end{array}$ & $\begin{array}{l}\text { Isalt. Mic. } \\
\text { Base }\end{array}$ & $\begin{array}{l}\text { Isalt. Mic. } \\
\text { Base }\end{array}$ & $\begin{array}{l}\text { Isalt. Mic. } \\
\text { Base }\end{array}$ & $\begin{array}{l}\text { Isalt. Mic. } \\
\text { Base }\end{array}$ & $\begin{array}{l}\text { Isalt. Mic. } \\
\text { Base }\end{array}$ & $\begin{array}{l}\text { Isalt. Mic. } \\
\text { Base }\end{array}$ & $\begin{array}{l}\text { Isalt. Mic. } \\
\text { Base }\end{array}$ & $\begin{array}{l}\text { Isalt. Mic. } \\
\text { Base }\end{array}$ & $\begin{array}{l}\text { Isalt. Mic. } \\
\text { Base }\end{array}$ \\
\hline Prof. & 132,2 & 165,1 & 165,1 & 165,1 & 165,1 & 165,1 & 157,2 & 157,2 & 157,2 & 157,2 & 157,2 & 157,2 & 157,2 & 157,2 & 157,2 & 157,2 \\
\hline Análise & 49 & 50 & 51 & 52 & 53 & 54 & 55 & 56 & 57 & 58 & 59 & 60 & 61 & 62 & 63 & 64 \\
\hline $\mathrm{SiO}_{2}$ & n.d. & n.d. & n.d. & n.d. & n.d. & n.d. & n.d. & n.d. & n.d. & n.d. & n.d. & n.d. & n.d. & n.d. & n.d. & n.d. \\
\hline $\mathrm{FeO}$ & n.d. & n.d. & n.d. & n.d. & n.d. & n.d. & n.d. & n.d. & n.d. & n.d. & n.d. & n.d. & n.d. & n.d. & n.d. & n.d. \\
\hline $\mathrm{MgO}$ & n.d. & n.d. & n.d. & n.d. & n.d. & n.d. & n.d. & n.d. & n.d. & n.d. & n.d. & n.d. & n.d. & n.d. & n.d. & n.d. \\
\hline $\mathrm{CaO}$ & 56,67 & 55,32 & 54,37 & 54,54 & 54,51 & 54,55 & 54,96 & 55,46 & 55,50 & 54,81 & 55,21 & 55,33 & 53,95 & 54,78 & 54,95 & 54,47 \\
\hline $\mathrm{BaO}$ & n.d. & n.d. & n.d. & n.d. & n.d. & n.d. & n.d. & n.d. & n.d. & n.d. & n.d. & n.d. & n.d. & n.d. & n.d. & n.d. \\
\hline $\mathrm{SrO}$ & n.d. & n.d. & 1,22 & 0,95 & 0,90 & 1,10 & 0,55 & 0,44 & 0,43 & 0,67 & 0,52 & 0,57 & 0,82 & 0,66 & 0,67 & 0,90 \\
\hline $\mathrm{Na}_{2} \mathrm{O}$ & n.d. & n.d. & n.d. & 0,30 & n.d. & n.d. & 0,13 & 0,15 & 0,17 & 0,25 & 0,15 & 0,18 & 0,32 & 0,13 & n.d. & 0,25 \\
\hline $\mathrm{P}_{2} \mathrm{O}_{5}$ & 41,51 & 40,98 & 40,82 & 40,68 & 41,00 & 40,85 & 40,81 & 40,72 & 40,79 & 40,92 & 40,77 & 40,78 & 40,73 & 40,97 & 40,98 & 40,97 \\
\hline $\mathrm{La}_{2} \mathrm{O}_{3}$ & n.d. & n.d. & n.d. & n.d. & n.d. & n.d. & n.d. & n.d. & n.d. & n.d. & n.d. & n.d. & n.d. & n.d. & n.d. & n.d. \\
\hline $\mathrm{Ce}_{2} \mathrm{O}_{3}$ & n.d. & n.d. & n.d. & n.d. & n.d. & n.d. & n.d. & n.d. & n.d. & n.d. & n.d. & n.d. & 0,87 & n.d. & n.d. & n.d. \\
\hline $\mathrm{Pr}_{2} \mathrm{O}_{3}$ & n.d. & n.d. & n.d. & n.d. & n.d. & n.d. & n.d. & n.d. & n.d. & n.d. & n.d. & n.d. & n.d. & n.d. & n.d. & n.d. \\
\hline $\mathrm{Nd}_{2} \mathrm{O}_{3}$ & n.d. & n.d. & n.d. & n.d. & n.d. & n.d. & n.d. & n.d. & n.d. & n.d. & n.d. & n.d. & n.d. & n.d. & n.d. & n.d. \\
\hline $\mathrm{SO}_{3}$ & n.d. & n.d. & n.d. & n.d. & n.d. & n.d. & n.d. & n.d. & n.d. & n.d. & n.d. & n.d. & n.d. & n.d. & n.d. & n.d. \\
\hline $\mathrm{F}$ & n.d. & 3,57 & 3,40 & 3,30 & 3,38 & 3,21 & 3,30 & 2,71 & 2,48 & 2,94 & 2,93 & 2,54 & 2,89 & 3,13 & 3,04 & 3,05 \\
\hline $\mathrm{Cl}$ & n.d. & n.d. & n.d. & n.d. & n.d. & n.d. & n.d. & n.d. & n.d. & n.d. & n.d. & n.d. & n.d. & n.d. & n.d. & n.d. \\
\hline H & 1,82 & 0,13 & 0,20 & 0,25 & 0,22 & 0,29 & 0,25 & 0,53 & 0,63 & 0,42 & 0,43 & 0,61 & 0,44 & 0,33 & 0,38 & 0,37 \\
\hline TOTAL & 100,00 & 100,00 & 100,00 & 100,00 & 100,00 & 100,01 & 100,00 & 100,01 & 100,01 & 100,01 & 100,01 & 100,01 & 100,01 & 100,01 & 100,01 & 100,01 \\
\hline $\mathrm{Si}$ & - & - & - & - & - & - & - & - & - & - & - & - & - & - & - & - \\
\hline $\mathrm{Fe} 2$ & - & - & - & - & - & - & - & - & - & - & - & - & - & - & - & - \\
\hline $\mathrm{Mg}$ & - & - & - & - & - & - & - & - & - & - & - & - & - & - & - & - \\
\hline $\mathrm{Ca}$ & 10,031 & 9,759 & 9,644 & 9,678 & 9,645 & 9,673 & 9,731 & 9,832 & 9,840 & 9,707 & 9,783 & 9,814 & 9,603 & 9,694 & 9,725 & 9,649 \\
\hline $\mathrm{Ba}$ & - & - & - & - & - & - & - & - & - & - & - & - & - & - & - & - \\
\hline $\mathrm{Sr}$ & - & - & 0,117 & 0,091 & 0,086 & 0,106 & 0,053 & 0,042 & 0,042 & 0,064 & 0,050 & 0,055 & 0,079 & 0,063 & 0,064 & 0,086 \\
\hline $\mathrm{Na}$ & - & - & - & 0,095 & - & - & 0,042 & 0,048 & 0,055 & 0,081 & 0,048 & 0,058 & 0,104 & 0,042 & - & 0,081 \\
\hline$P$ & 5,806 & 5,712 & 5,720 & 5,704 & 5,734 & 5,724 & 5,709 & 5,705 & 5,714 & 5,727 & 5,709 & 5,715 & 5,729 & 5,729 & 5,730 & 5,735 \\
\hline $\mathrm{La}$ & - & - & - & - & - & - & - & $\begin{array}{lll}- & -\end{array}$ & - & $\begin{array}{lll}- & -\end{array}$ & - & - & - & - & - & - \\
\hline $\mathrm{Ce}$ & - & - & - & - & - & - & - & - & - & - & - & - & 0,053 & - & - & - \\
\hline Pr & - & - & - & - & - & - & - & - & - & - & - & - & - & - & - & - \\
\hline $\mathrm{Nd}$ & - & - & - & - & - & - & - & - & - & - & - & - & - & - & - & - \\
\hline S & - & - & - & - & - & - & - & - & - & - & - & - & - & - & - & - \\
\hline Cátions & 15,837 & 15,471 & 15,481 & 15,568 & 15,465 & 15,503 & 15,534 & 15,628 & 15,650 & 15,579 & 15,591 & 15,642 & 15,567 & 15,528 & 15,519 & 15,551 \\
\hline
\end{tabular}

Análises 49- 64: apatita ígnea no perovskita bebedourito intemperizado. 
Análises EDS de Apatita (V).

\begin{tabular}{|c|c|c|c|c|c|c|c|c|c|c|c|c|c|c|c|c|}
\hline Rocha & Beb. & Beb. & Beb. & Beb. & Beb. & Beb. & Beb. & Beb. & Beb. & Beb. & Beb. & Beb. & Beb. & Beb. & Beb. & Beb. \\
\hline Intemp. & $\begin{array}{l}\text { Isalt. Mic. } \\
\text { Base }\end{array}$ & $\begin{array}{l}\text { Isalt. Mic. } \\
\text { Base }\end{array}$ & $\begin{array}{r}\text { Isalt. } \\
\text { Oxidado }\end{array}$ & $\begin{array}{r}\text { Isalt. } \\
\text { Oxidado }\end{array}$ & $\begin{array}{r}\text { Isalt. } \\
\text { Oxidado }\end{array}$ & $\begin{array}{r}\text { Isalt. } \\
\text { Oxidado }\end{array}$ & $\begin{array}{r}\text { Isalt. } \\
\text { Oxidado }\end{array}$ & $\begin{array}{r}\text { Isalt. } \\
\text { Oxidado }\end{array}$ & $\begin{array}{r}\text { Isalt. } \\
\text { Oxidado }\end{array}$ & $\begin{array}{r}\text { Isalt. } \\
\text { Oxidado }\end{array}$ & $\begin{array}{r}\text { Isalt. } \\
\text { Oxidado }\end{array}$ & $\begin{array}{r}\text { Isalt. } \\
\text { Oxidado }\end{array}$ & $\begin{array}{r}\text { Isalt. } \\
\text { Oxidado }\end{array}$ & $\begin{array}{r}\text { Isalt. } \\
\text { Oxidado }\end{array}$ & $\begin{array}{r}\text { Isalt. } \\
\text { Oxidado }\end{array}$ & $\begin{array}{l}\text { Rocha } \\
\text { Fresca }\end{array}$ \\
\hline Prof. & 157,2 & 157,2 & $\begin{array}{l}120,9 \\
\end{array}$ & 120,9 & 120,9 & \begin{tabular}{ll|}
120,9 \\
\end{tabular} & 120,9 & \begin{tabular}{ll|}
120,9 \\
\end{tabular} & \begin{tabular}{ll|}
120,9 \\
\end{tabular} & 120,9 & 120,9 & 120,9 & 120,9 & 120,9 & 120,9 & 106,6 \\
\hline Análise & 65 & 66 & 67 & 68 & 69 & 70 & 71 & 72 & 73 & 74 & 75 & 76 & 77 & 78 & 79 & 80 \\
\hline $\mathrm{SiO}_{2}$ & n.d. & n.d. & n.d. & n.d. & 0,01 & 0,01 & n.d. & n.d. & n.d. & n.d. & n.d. & n.d. & n.d. & n.d. & n.d. & n.d. \\
\hline $\mathrm{FeO}$ & n.d. & n.d. & n.d. & n.d. & n.d. & n.d. & n.d. & n.d. & n.d. & n.d. & n.d. & n.d. & n.d. & n.d. & n.d. & n.d. \\
\hline $\mathrm{MgO}$ & n.d. & n.d. & n.d. & n.d. & n.d. & n.d. & n.d. & n.d. & n.d. & n.d. & n.d. & n.d. & n.d. & n.d. & n.d. & n.d. \\
\hline $\mathrm{CaO}$ & 54,10 & 54,43 & 53,80 & 54,16 & 53,32 & 53,17 & 52,87 & 52,72 & 53,21 & 53,60 & 53,62 & 53,43 & 53,22 & 53,42 & 53,62 & 55,69 \\
\hline $\mathrm{BaO}$ & n.d. & n.d. & n.d. & n.d. & n.d. & n.d. & n.d. & n.d. & n.d. & n.d. & n.d. & n.d. & n.d. & n.d. & n.d. & n.d. \\
\hline $\mathrm{SrO}$ & 1,06 & 0,94 & 0,75 & 0,65 & 0,71 & 0,72 & 0,80 & 0,91 & 0,72 & 0,71 & 0,80 & 1,00 & 0,90 & 0,92 & 0,88 & n.d. \\
\hline $\mathrm{Na}_{2} \mathrm{O}$ & 0,34 & 0,34 & 0,27 & 0,23 & 0,26 & n.d. & 0,45 & 0,54 & 0,42 & 0,34 & 0,43 & 0,53 & 0,47 & 0,43 & 0,53 & n.d. \\
\hline $\mathrm{P}_{2} \mathrm{O}_{5}$ & 41,19 & 41,02 & 42,11 & 41,66 & 42,45 & 42,79 & 42,43 & 42,33 & 42,49 & 42,00 & 42,10 & 41,86 & 42,18 & 41,95 & 41,94 & 41,21 \\
\hline $\mathrm{La}_{2} \mathrm{O}_{3}$ & n.d. & n.d. & n.d. & n.d. & n.d. & n.d. & n.d. & n.d. & n.d. & n.d. & n.d. & n.d. & n.d. & n.d. & n.d. & n.d. \\
\hline $\mathrm{Ce}_{2} \mathrm{O}_{3}$ & n.d. & n.d. & n.d. & n.d. & n.d. & n.d. & n.d. & n.d. & n.d. & n.d. & n.d. & n.d. & n.d. & n.d. & n.d. & n.d. \\
\hline $\mathrm{Pr}_{2} \mathrm{O}_{3}$ & n.d. & n.d. & n.d. & n.d. & n.d. & n.d. & n.d. & n.d. & n.d. & n.d. & n.d. & n.d. & n.d. & n.d. & n.d. & n.d. \\
\hline $\mathrm{Nd}_{2} \mathrm{O}_{3}$ & n.d. & n.d. & n.d. & n.d. & n.d. & n.d. & n.d. & n.d. & n.d. & n.d. & n.d. & n.d. & n.d. & n.d. & n.d. & n.d. \\
\hline $\mathrm{SO}_{3}$ & n.d. & n.d. & n.d. & n.d. & n.d. & n.d. & n.d. & n.d. & n.d. & n.d. & n.d. & n.d. & n.d. & n.d. & n.d. & n.d. \\
\hline F & 2,86 & 2,77 & 2,38 & 2,81 & 2,71 & 2,83 & 3,09 & 3,19 & 2,55 & 2,92 & 2,34 & 2,59 & 2,69 & 2,78 & 2,32 & 2,46 \\
\hline $\mathrm{Cl}$ & n.d. & n.d. & n.d. & n.d. & n.d. & n.d. & n.d. & n.d. & n.d. & n.d. & n.d. & n.d. & n.d. & n.d. & n.d. & n.d. \\
\hline H & 0,46 & 0,50 & 0,70 & 0,49 & 0,55 & 0,50 & 0,37 & 0,32 & 0,62 & 0,44 & 0,72 & 0,60 & 0,55 & 0,51 & 0,72 & 0,66 \\
\hline TOTAL & 100,01 & 100,01 & 100,01 & 100,01 & 100,01 & 100,01 & 100,01 & 100,01 & 100,01 & 100,01 & 100,01 & 100,01 & 100,01 & 100,01 & 100,01 & 100,01 \\
\hline $\mathrm{Si}$ & - & - & - & - & 0,002 & 0,002 & - & - & - & - & - & - & - & - & - & - \\
\hline $\mathrm{Fe} 2$ & - & - & - & - & - & - & - & - & - & - & - & - & - & - & - & - \\
\hline $\mathrm{Mg}$ & - & - & - & - & - & - & - & - & - & - & - & - & - & - & - & - \\
\hline $\mathrm{Ca}$ & 9,579 & 9,646 & 9,463 & 9,546 & 9,348 & 9,297 & 9,268 & 9,251 & 9,331 & 9,424 & 9,436 & 9,420 & 9,357 & 9,406 & 9,451 & 9,829 \\
\hline $\mathrm{Ba}$ & - & - & - & - & - & - & - & - & - & - & - & - & - & - & - & - \\
\hline $\mathrm{Sr}$ & 0,102 & 0,090 & 0,072 & 0,062 & 0,067 & 0,068 & 0,076 & 0,087 & 0,068 & 0,067 & 0,076 & 0,096 & 0,086 & 0,087 & 0,084 & - \\
\hline $\mathrm{Na}$ & 0,108 & 0,110 & 0,087 & 0,074 & 0,083 & - & 0,143 & 0,171 & 0,132 & 0,109 & 0,138 & 0,168 & 0,148 & 0,138 & 0,168 & - \\
\hline $\mathrm{P}$ & 5,762 & 5,745 & 5,853 & 5,802 & 5,882 & 5,912 & 5,878 & 5,869 & 5,889 & 5,835 & 5,854 & 5,832 & 5,860 & 5,837 & 5,840 & 5,748 \\
\hline $\mathrm{La}$ & - & - & - & - & - & - & - & - & - & $\begin{array}{lll}- & -\end{array}$ & $\begin{array}{lll}- & -\end{array}$ & $\begin{array}{lll}- & - \\
-1\end{array}$ & - & - & - & - \\
\hline $\mathrm{Ce}$ & - & - & - & - & - & - & - & - & - & $\begin{array}{lll}- & \text { r }\end{array}$ & $\begin{array}{lll}- & \text { r }\end{array}$ & $\begin{array}{lll}- & \text { r }\end{array}$ & - & - & - & - \\
\hline $\operatorname{Pr}$ & - & - & - & - & - & - & - & - & - & - & - & - & - & - & - & - \\
\hline $\mathrm{Nd}$ & - & - & - & - & - & - & - & - & - & - & $\begin{array}{lll}- & \text { r }\end{array}$ & $\begin{array}{ll}- \\
-\end{array}$ & - & - & - & - \\
\hline S & - & - & - & - & - & - & - & - & - & - & - & - & - & - & - & - \\
\hline Cátions & 15,551 & 15,591 & 15,474 & 15,483 & 15,382 & 15,279 & 15,364 & 15,377 & 15,420 & 15,436 & 15,504 & 15,516 & 15,451 & 15,468 & 15,542 & 15,577 \\
\hline
\end{tabular}

Análises 65- 79: apatita ígnea no perovskita bebedourito intemperizado. Análise 80: apatita ígnea no perovskita bebedourito. 
Análises EDS de Apatita (VI).

\begin{tabular}{|c|c|c|c|c|c|c|c|c|c|c|c|c|c|c|c|c|}
\hline Rocha & Beb. & Beb. & Beb. & Beb. & Beb. & Beb. & Beb. & Beb. & Beb. & Beb. & Beb. & Beb. & Beb. & Beb. & Beb. & Beb. \\
\hline Intemp. & $\begin{array}{l}\text { Rocha } \\
\text { Fresca }\end{array}$ & $\begin{array}{l}\text { Rocha } \\
\text { Fresca }\end{array}$ & $\begin{array}{l}\text { Rocha } \\
\text { Fresca }\end{array}$ & $\begin{array}{l}\text { Rocha } \\
\text { Fresca }\end{array}$ & $\begin{array}{l}\text { Rocha } \\
\text { Fresca }\end{array}$ & $\begin{array}{l}\text { Rocha } \\
\text { Fresca }\end{array}$ & $\begin{array}{l}\text { Rocha } \\
\text { Fresca }\end{array}$ & $\begin{array}{l}\text { Rocha } \\
\text { Fresca }\end{array}$ & $\begin{array}{l}\text { Rocha } \\
\text { Fresca }\end{array}$ & $\begin{array}{l}\text { Rocha } \\
\text { Fresca }\end{array}$ & $\begin{array}{l}\text { Rocha } \\
\text { Fresca }\end{array}$ & $\begin{array}{l}\text { Rocha } \\
\text { Fresca }\end{array}$ & $\begin{array}{l}\text { Rocha } \\
\text { Fresca }\end{array}$ & $\begin{array}{l}\text { Rocha } \\
\text { Fresca }\end{array}$ & $\begin{array}{l}\text { Isalt. Mic. } \\
\text { Base }\end{array}$ & $\begin{array}{l}\text { Isalt. Mic. } \\
\text { Base }\end{array}$ \\
\hline Prof. & 106,6 & 106,6 & 106,60 & 106,60 & 106,6 & 106,60 & 106,6 & 106,6 & 106,6 & 106,6 & 106,5 & 106,5 & 106,5 & 106,5 & 157,2 & 157,2 \\
\hline Análise & 81 & 82 & 83 & 84 & 85 & 86 & 87 & 88 & 89 & 90 & 91 & 92 & 93 & 94 & 95 & 96 \\
\hline $\mathrm{SiO}_{2}$ & n.d. & n.d. & 0,50 & 0,54 & 0,47 & 0,44 & n.d. & 0,54 & n.d. & 0,38 & n.d. & n.d. & n.d. & n.d. & 0,01 & n.d. \\
\hline $\mathrm{FeO}$ & n.d. & n.d. & 10,90 & 10,37 & n.d. & 11,11 & n.d. & n.d. & 10,78 & n.d. & n.d. & n.d. & n.d. & n.d. & n.d. & n.d. \\
\hline $\mathrm{MgO}$ & n.d. & n.d. & n.d. & n.d. & n.d. & n.d. & 0,01 & n.d. & n.d. & n.d. & 0,01 & n.d. & n.d. & n.d. & 0,51 & 0,55 \\
\hline $\mathrm{CaO}$ & 56,03 & 54,65 & 49,25 & 49,37 & 55,75 & 49,12 & 55,54 & 55,66 & 49,23 & 55,92 & 55,99 & 55,53 & 55,21 & 55,70 & 58,09 & 58,59 \\
\hline $\mathrm{BaO}$ & n.d. & n.d. & n.d. & n.d. & n.d. & n.d. & n.d. & n.d. & n.d. & n.d. & n.d. & n.d. & n.d. & n.d. & n.d. & n.d. \\
\hline $\mathrm{SrO}$ & n.d. & 0,81 & n.d. & n.d. & n.d. & n.d. & n.d. & n.d. & n.d. & n.d. & n.d. & 0,60 & n.d. & n.d. & n.d. & n.d. \\
\hline $\mathrm{Na}_{2} \mathrm{O}$ & n.d. & n.d. & 0,22 & 0,34 & n.d. & 0,30 & n.d. & n.d. & 0,26 & n.d. & n.d. & n.d. & n.d. & n.d. & n.d. & n.d. \\
\hline $\mathrm{P}_{2} \mathrm{O}_{5}$ & 40,88 & 41,41 & 36,20 & 36,51 & 40,72 & 36,08 & 41,54 & 40,72 & 36,81 & 40,60 & 40,76 & 40,59 & 41,39 & 40,94 & 36,97 & 36,60 \\
\hline $\mathrm{La}_{2} \mathrm{O}_{3}$ & n.d. & n.d. & n.d. & n.d. & n.d. & n.d. & n.d. & n.d. & n.d. & n.d. & n.d. & n.d. & n.d. & n.d. & n.d. & n.d. \\
\hline $\mathrm{Ce}_{2} \mathrm{O}_{3}$ & n.d. & n.d. & n.d. & n.d. & n.d. & n.d. & n.d. & n.d. & n.d. & n.d. & n.d. & n.d. & n.d. & n.d. & n.d. & n.d. \\
\hline $\mathrm{Pr}_{2} \mathrm{O}_{3}$ & n.d. & n.d. & n.d. & n.d. & n.d. & n.d. & n.d. & n.d. & n.d. & n.d. & n.d. & n.d. & n.d. & n.d. & n.d. & n.d. \\
\hline $\mathrm{Nd}_{2} \mathrm{O}_{3}$ & n.d. & n.d. & n.d. & n.d. & n.d. & n.d. & n.d. & n.d. & n.d. & n.d. & n.d. & n.d. & n.d. & n.d. & n.d. & n.d. \\
\hline $\mathrm{SO}_{3}$ & n.d. & n.d. & n.d. & n.d. & n.d. & n.d. & n.d. & n.d. & n.d. & n.d. & n.d. & n.d. & n.d. & n.d. & n.d. & n.d. \\
\hline $\mathrm{F}$ & 2,43 & 2,51 & n.d. & n.d. & 2,37 & n.d. & 2,08 & 2,43 & n.d. & 2,45 & 2,73 & 2,80 & 3,01 & 2,93 & 4,99 & 4,71 \\
\hline $\mathrm{Cl}$ & n.d. & n.d. & n.d. & n.d. & n.d. & n.d. & n.d. & n.d. & n.d. & n.d. & n.d. & n.d. & n.d. & n.d. & n.d. & n.d. \\
\hline $\mathrm{H}$ & 0,66 & 0,63 & 1,70 & 1,71 & 0,69 & 1,70 & 0,84 & 0,67 & 1,71 & 0,65 & 0,52 & 0,48 & 0,40 & 0,43 & - & - \\
\hline TOTAL & 100,01 & 100,01 & 98,78 & 98,83 & 100,01 & 98,75 & 100,01 & 100,01 & 98,79 & 100,01 & 100,01 & 100,01 & 100,01 & 100,01 & 99,98 & 99,99 \\
\hline $\mathrm{Si}$ & - & - & 0,087 & 0,094 & 0,078 & 0,077 & - & 0,088 & - & 0,063 & - & - & - & - & 0,002 & - \\
\hline $\mathrm{Fe} 2$ & - & - & 1,603 & 1,520 & - & 1,638 & - & - & 1,583 & - & - & - & - & - & - & - \\
\hline $\mathrm{Mg}$ & - & - & - & - & - & - & 0,003 & - & - & - & 0,003 & - & - & - & 0,128 & 0,139 \\
\hline $\mathrm{Ca}$ & 9,914 & 9,658 & 9,282 & 9,268 & 9,846 & 9,275 & 9,788 & 9,826 & 9,262 & 9,889 & 9,907 & 9,857 & 9,723 & 9,841 & 10,492 & 10,615 \\
\hline $\mathrm{Ba}$ & - & - & - & - & - & - & - & - & - & - & - & - & - & - & - & - \\
\hline $\mathrm{Sr}$ & - & 0,078 & - & - & - & - & - & - & - & - & - & 0,058 & - & - & - & - \\
\hline $\mathrm{Na}$ & - & - & 0,076 & 0,115 & - & 0,102 & - & - & 0,088 & - & - & - & - & - & - & - \\
\hline$P$ & 5,715 & 5,782 & 5,391 & 5,415 & 5,683 & 5,383 & 5,785 & 5,680 & 5,474 & 5,674 & 5,700 & 5,693 & 5,759 & 5,716 & 5,275 & 5,239 \\
\hline $\mathrm{La}$ & - & - & - & - & - & - & - & - & - & - & - & - & - & - & - & - \\
\hline $\mathrm{Ce}$ & - & - & - & - & - & - & - & - & - & - & - & - & - & - & - & - \\
\hline $\operatorname{Pr}$ & - & - & - & - & - & - & - & - & - & - & - & - & - & - & - & - \\
\hline $\mathrm{Nd}$ & - & - & - & - & - & - & - & - & - & - & - & - & - & - & - & $\begin{array}{lll}- & \text { r }\end{array}$ \\
\hline S & - & - & - & - & - & - & - & - & - & - & - & - & - & - & - & - \\
\hline Cátions & 15,629 & 15,518 & 16,438 & 16,412 & 15,607 & 16,475 & 15,575 & 15,594 & 16,407 & 15,625 & 15,609 & 15,608 & 15,482 & 15,557 & 15,897 & 15,993 \\
\hline
\end{tabular}

Análises 81- 94: apatita ígnea no perovskita bebedourito. Análises 95 e 96: apatita intempérica, fratura. 
Análises EDS de Apatita (VII).

\begin{tabular}{|c|c|c|c|c|c|c|c|c|c|c|c|c|c|c|c|c|}
\hline Rocha & Beb. & Beb. & Beb. & Beb. & Beb. & Beb. & Beb. & Beb. & Beb. & Beb. & Beb. & Beb. & Beb. & Beb. & Beb. & Beb. \\
\hline Intemp. & $\begin{array}{l}\text { Isalt. Mic. } \\
\text { Base }\end{array}$ & $\begin{array}{l}\text { Isalt. Mic. } \\
\text { Base }\end{array}$ & $\begin{array}{l}\text { Isalt. Mic. } \\
\text { Base }\end{array}$ & $\begin{array}{l}\text { Isalt. Mic. } \\
\text { Base }\end{array}$ & $\begin{array}{l}\text { Isalt. Mic. } \\
\text { Base }\end{array}$ & $\begin{array}{l}\text { Isalt. Mic. } \\
\text { Base }\end{array}$ & $\begin{array}{l}\text { Isalt. Mic. } \\
\text { Base }\end{array}$ & $\begin{array}{l}\text { Isalt. Mic. } \\
\text { Base }\end{array}$ & $\begin{array}{l}\text { Isalt. Mic. } \\
\text { Base }\end{array}$ & $\begin{array}{l}\text { Isalt. Mic. } \\
\text { Base }\end{array}$ & $\begin{array}{l}\text { Isalt. Mic. } \\
\text { Base }\end{array}$ & $\begin{array}{l}\text { Isalt. Mic. } \\
\text { Base }\end{array}$ & $\begin{array}{l}\text { Isalt. Mic. } \\
\text { Base }\end{array}$ & $\begin{array}{l}\text { Isalt. Mic. } \\
\text { Base }\end{array}$ & $\begin{array}{l}\text { Isalt. Mic. } \\
\text { Base }\end{array}$ & $\begin{array}{r}\text { Isalt. Mic. } \\
\text { Base }\end{array}$ \\
\hline Prof. & 157,2 & 157,2 & 157,2 & 157,2 & 157,2 & 157,2 & 157,2 & 157,2 & 157,2 & 145,2 & 145,2 & 145,2 & 145,2 & 145,2 & 145,2 & 145,2 \\
\hline Análise & 97 & 98 & 99 & 100 & 101 & 102 & 103 & 104 & 105 & 106 & 107 & 108 & 109 & 110 & 111 & 112 \\
\hline $\mathrm{SiO}_{2}$ & n.d. & n.d. & n.d. & n.d. & n.d. & n.d. & n.d. & n.d. & n.d. & n.d. & n.d. & n.d. & n.d. & n.d. & n.d. & n.d. \\
\hline $\mathrm{FeO}$ & n.d. & n.d. & n.d. & n.d. & n.d. & n.d. & n.d. & n.d. & n.d. & n.d. & n.d. & n.d. & n.d. & n.d. & n.d. & n.d. \\
\hline $\mathrm{MgO}$ & 0,40 & 0,56 & 0,15 & n.d. & 0,33 & 0,41 & 0,35 & n.d. & 0,30 & 0,16 & n.d. & n.d. & n.d. & n.d. & n.d. & 0,28 \\
\hline $\mathrm{CaO}$ & 57,93 & 57,18 & 56,47 & 57,80 & 58,57 & 57,02 & 56,85 & 56,84 & 56,73 & 57,80 & 56,98 & 56,57 & 57,19 & 57,33 & 58,37 & 57,89 \\
\hline $\mathrm{BaO}$ & 0,76 & n.d. & n.d. & n.d. & n.d. & n.d. & n.d. & n.d. & n.d. & n.d. & n.d. & n.d. & n.d. & n.d. & n.d. & n.d. \\
\hline $\mathrm{SrO}$ & n.d. & n.d. & n.d. & n.d. & n.d. & n.d. & n.d. & n.d. & n.d. & n.d. & n.d. & n.d. & n.d. & n.d. & n.d. & n.d. \\
\hline $\mathrm{Na}_{2} \mathrm{O}$ & n.d. & n.d. & n.d. & n.d. & n.d. & n.d. & n.d. & n.d. & n.d. & n.d. & n.d. & n.d. & n.d. & n.d. & n.d. & n.d. \\
\hline $\mathrm{P}_{2} \mathrm{O}_{5}$ & 36,67 & 37,37 & 38,43 & 37,56 & 36,56 & 37,67 & 37,63 & 38,08 & 38,05 & 38,28 & 39,27 & 39,73 & 39,10 & 38,94 & 38,07 & 38,13 \\
\hline $\mathrm{La}_{2} \mathrm{O}_{3}$ & n.d. & n.d. & n.d. & n.d. & n.d. & n.d. & n.d. & n.d. & n.d. & n.d. & n.d. & n.d. & n.d. & n.d. & n.d. & n.d. \\
\hline $\mathrm{Ce}_{2} \mathrm{O}_{3}$ & n.d. & n.d. & n.d. & n.d. & n.d. & n.d. & n.d. & n.d. & n.d. & n.d. & n.d. & n.d. & n.d. & n.d. & n.d. & n.d. \\
\hline $\mathrm{Pr}_{2} \mathrm{O}_{3}$ & n.d. & n.d. & n.d. & n.d. & n.d. & n.d. & n.d. & n.d. & n.d. & n.d. & n.d. & n.d. & n.d. & n.d. & n.d. & n.d. \\
\hline $\mathrm{Nd}_{2} \mathrm{O}_{3}$ & n.d. & n.d. & n.d. & n.d. & n.d. & n.d. & n.d. & n.d. & n.d. & n.d. & n.d. & n.d. & n.d. & n.d. & n.d. & n.d. \\
\hline $\mathrm{SO}_{3}$ & n.d. & n.d. & n.d. & n.d. & n.d. & n.d. & n.d. & n.d. & n.d. & n.d. & n.d. & n.d. & n.d. & n.d. & n.d. & n.d. \\
\hline $\mathrm{F}$ & 4,68 & 5,82 & 5,92 & 5,39 & 5,24 & 5,85 & 6,31 & 6,17 & 5,88 & 3,74 & 3,72 & 3,60 & 3,63 & 3,69 & 3,40 & 3,64 \\
\hline $\mathrm{Cl}$ & n.d. & n.d. & n.d. & n.d. & n.d. & n.d. & n.d. & n.d. & n.d. & n.d. & n.d. & n.d. & n.d. & n.d. & n.d. & n.d. \\
\hline $\mathrm{H}$ & - & - & - & - & - & - & - & - & - & 0,02 & 0,04 & 0,10 & 0,08 & 0,05 & 0,17 & 0,06 \\
\hline TOTAL & 99,99 & 99,97 & 99,96 & 99,98 & 99,98 & 99,97 & 99,95 & 99,96 & 99,97 & 100,00 & 100,00 & 100,00 & 100,00 & 100,00 & 100,00 & 100,00 \\
\hline $\mathrm{Si}$ & - & - & - & $\begin{array}{ll}- & \text { r }\end{array}$ & - & $\begin{array}{lll}- & \text { r }\end{array}$ & - & $\begin{array}{ll}- & \text { r }\end{array}$ & - & - & - & - & - & - & - & - \\
\hline $\mathrm{Fe} 2$ & - & - & - & - & - & - & - & - & - & - & - & - & - & - & - & - \\
\hline $\mathrm{Mg}$ & 0,100 & 0,141 & 0,038 & - & 0,082 & 0,102 & 0,087 & - & 0,074 & 0,041 & - & - & - & - & - & 0,069 \\
\hline $\mathrm{Ca}$ & 10,532 & 10,278 & 10,085 & 10,401 & 10,609 & 10,232 & 10,196 & 10,174 & 10,156 & 10,382 & 10,168 & 10,065 & 10,220 & 10,255 & 10,512 & 10,407 \\
\hline $\mathrm{Ba}$ & 0,051 & - & - & - & - & - & - & - & - & - & - & - & - & - & - & - \\
\hline $\mathrm{Sr}$ & - & - & - & - & - & - & - & - & - & - & - & - & - & - & - & - \\
\hline $\mathrm{Na}$ & - & - & - & - & - & - & - & - & - & - & - & - & - & - & - & - \\
\hline $\mathrm{P}$ & 5,268 & 5,308 & 5,424 & 5,341 & 5,232 & 5,341 & 5,333 & 5,387 & 5,382 & 5,433 & 5,538 & 5,586 & 5,522 & 5,504 & 5,417 & 5,417 \\
\hline $\mathrm{La}$ & - & - & - & $\begin{array}{lll}- & -\end{array}$ & - & $\begin{array}{lll}- & -\end{array}$ & - & - & - & - & - & - & - & - & - & - \\
\hline $\mathrm{Ce}$ & - & - & - & $\begin{array}{lll}- & \text { r }\end{array}$ & - & $\begin{array}{lll}- & \text { r }\end{array}$ & - & $\begin{array}{lll}- & \text { r }\end{array}$ & - & - & - & - & - & - & - & - \\
\hline $\operatorname{Pr}$ & - & - & - & - & - & - & - & - & - & - & - & - & - & - & - & - \\
\hline $\mathrm{Nd}$ & - & - & - & $\begin{array}{lll}- & \text { r }\end{array}$ & - & $\begin{array}{lll}- & \text { r }\end{array}$ & - & - & - & - & - & - & - & - & - & - \\
\hline S & - & - & - & - & - & - & - & - & - & - & - & - & - & - & - & - \\
\hline Cátions & 15,951 & 15,727 & 15,547 & 15,743 & 15,923 & 15,675 & 15,617 & 15,561 & 15,612 & 15,856 & 15,706 & 15,651 & 15,742 & 15,759 & 15,929 & 15,893 \\
\hline
\end{tabular}

Análises 97- 105: apatita intempérica, fratura. Análises 98-112 apatita intempérica, criptocristalina radial. 
Análises WDS de Apatita.

\begin{tabular}{|c|c|c|c|c|c|c|c|}
\hline Rocha & Beb. & Beb. & Beb. & Beb. & Beb. & Fosc. & Fosc. \\
\hline Intemp. & $\begin{array}{r}\text { Isalt. Mic. } \\
\text { Base }\end{array}$ & $\begin{array}{r}\text { Isalt. Mic. } \\
\text { Base }\end{array}$ & $\begin{array}{r}\text { Isalt. Mic. } \\
\text { Base }\end{array}$ & $\begin{array}{r}\text { Isalt. Mic. } \\
\text { Base }\end{array}$ & $\begin{array}{r}\text { Isalt. Mic. } \\
\text { Topo }\end{array}$ & $\begin{array}{r}\text { Isalt. } \\
\text { Oxidado } \\
\end{array}$ & $\begin{array}{r}\text { Isalt. } \\
\text { Oxidado } \\
\end{array}$ \\
\hline Prof. & 157,2 & 157,2 & 157,2 & 157,2 & 130 & 127 & 127 \\
\hline Análise & 3 & 4 & 6 & 7 & 9 & 11 & 12 \\
\hline $\mathrm{SiO}_{2}$ & 0,05 & n.d. & n.d. & 0,01 & 0,08 & 0,61 & 0,48 \\
\hline $\mathrm{FeO}$ & 0,04 & 0,03 & 0,04 & 0,07 & 0,07 & 0,71 & 0,14 \\
\hline $\mathrm{MgO}$ & 0,01 & 0,27 & 0,42 & 0,37 & 0,02 & 0,10 & 0,04 \\
\hline $\mathrm{CaO}$ & 54,03 & 54,72 & 53,96 & 53,84 & 53,27 & 53,17 & 54,71 \\
\hline $\mathrm{BaO}$ & 0,01 & 0,18 & 0,16 & 0,26 & 0,14 & 0,18 & n.d. \\
\hline $\mathrm{SrO}$ & 0,82 & 0,40 & 0,19 & 0,30 & 0,81 & 0,26 & 0,82 \\
\hline $\mathrm{Na}_{2} \mathrm{O}$ & 0,12 & 0,04 & 0,01 & 0,02 & 0,23 & n.d. & 0,12 \\
\hline $\mathrm{P}_{2} \mathrm{O}_{5}$ & 42,20 & 37,95 & 36,57 & 36,19 & 39,72 & 37,26 & 40,35 \\
\hline $\mathrm{La}_{2} \mathrm{O}_{3}$ & 0,10 & 0,01 & n.d. & n.d. & 0,19 & 0,05 & 0,06 \\
\hline $\mathrm{Ce}_{2} \mathrm{O}_{3}$ & 0,08 & n.d. & n.d. & 0,10 & 0,49 & 0,05 & 0,11 \\
\hline $\mathrm{Pr}_{2} \mathrm{O}_{3}$ & 0,01 & n.d. & n.d. & 0,10 & n.d. & n.d. & 0,02 \\
\hline $\mathrm{Nd}_{2} \mathrm{O}_{3}$ & n.d. & n.d. & n.d. & n.d. & 0,19 & 0,07 & 0,02 \\
\hline $\mathrm{SO}_{3}$ & n.d. & n.d. & n.d. & n.d. & n.d. & n.d. & n.d. \\
\hline $\mathrm{F}$ & 2,24 & 4,25 & 4,20 & 4,06 & 2,54 & 4,14 & 2,12 \\
\hline $\mathrm{Cl}$ & 0,02 & n.d. & 0,01 & n.d. & 0,02 & n.d. & 0,02 \\
\hline $\mathrm{H}$ & 0,75 & - & - & - & 0,55 & - & 0,78 \\
\hline TOTAL & 100,86 & 97,97 & 96,16 & 96,49 & 98,53 & 97,03 & 99,94 \\
\hline $\mathrm{Si}$ & 0,008 & - & - & 0,002 & 0,013 & 0,105 & 0,081 \\
\hline $\mathrm{Fe} 2$ & 0,005 & 0,005 & 0,006 & 0,011 & 0,009 & 0,103 & 0,020 \\
\hline $\mathrm{Mg}$ & 0,002 & 0,069 & 0,109 & 0,097 & 0,005 & 0,026 & 0,009 \\
\hline $\mathrm{Ca}$ & 9,532 & 9,999 & 10,104 & 10,133 & 9,718 & 9,820 & 9,815 \\
\hline $\mathrm{Ba}$ & 0,001 & 0,012 & 0,011 & 0,018 & 0,009 & 0,012 & 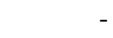 \\
\hline $\mathrm{Sr}$ & 0,079 & 0,040 & 0,019 & 0,030 & 0,080 & 0,026 & 0,080 \\
\hline $\mathrm{Na}$ & 0,039 & 0,013 & 0,004 & 0,005 & 0,076 & - & 0,040 \\
\hline $\mathrm{P}$ & 5,883 & 5,480 & 5,411 & 5,383 & 5,726 & 5,437 & 5,720 \\
\hline $\mathrm{La}$ & 0,006 & 0,001 & - & - & 0,012 & 0,003 & 0,004 \\
\hline $\mathrm{Ce}$ & 0,005 & - & - & 0,007 & 0,030 & 0,003 & 0,006 \\
\hline $\operatorname{Pr}$ & 0,001 & - & - & 0,007 & - & - & 0,001 \\
\hline $\mathrm{Nd}$ & - & - & - & - & 0,012 & 0,005 & 0,001 \\
\hline S & - & - & - & - & - & - & - \\
\hline Cátions & 15,585 & 15,628 & 15,700 & 15,758 & 15,711 & 15,584 & 15,785 \\
\hline
\end{tabular}

Análises 3, 4, 6 e 7: apatita ígnea no perovskita bebedourito. Análises 11 e 12: apatita no cumulado foscorítico. 
Análises WDS de Monazita (I).

\begin{tabular}{|c|c|c|c|c|c|c|c|c|c|c|c|c|c|c|c|c|}
\hline Rocha & Beb. & Beb. & Beb. & Beb. & Beb. & Beb. & Beb. & Beb. & Beb. & Beb. & Beb. & Beb. & Beb. & Beb. & Beb. & Beb. \\
\hline Intemp. & $\begin{array}{r}\text { Isalt. Mic. } \\
\text { Topo }\end{array}$ & $\begin{array}{r}\text { Isalt. Mic. } \\
\text { Topo }\end{array}$ & $\begin{array}{r}\text { Isalt. Mic. } \\
\text { Topo }\end{array}$ & $\begin{array}{r}\text { Isalt. Mic. } \\
\text { Topo }\end{array}$ & $\begin{array}{r}\text { Isalt. Mic. } \\
\text { Topo }\end{array}$ & $\begin{array}{r}\text { Isalt. Mic. } \\
\text { Topo }\end{array}$ & $\begin{array}{r}\text { Isalt. Mic. } \\
\text { Topo }\end{array}$ & $\begin{array}{r}\text { Isalt. Mic. } \\
\text { Topo }\end{array}$ & $\begin{array}{r}\text { Isalt. Mic. } \\
\text { Topo }\end{array}$ & $\begin{array}{r}\text { Isalt. Mic. } \\
\text { Topo }\end{array}$ & $\begin{array}{r}\text { Isalt. Mic. } \\
\text { Topo }\end{array}$ & $\begin{array}{r}\text { Isalt. Mic. } \\
\text { Topo }\end{array}$ & $\begin{array}{r}\text { Isalt. Mic. } \\
\text { Topo }\end{array}$ & $\begin{array}{r}\text { Isalt. Mic. } \\
\text { Topo }\end{array}$ & $\begin{array}{r}\text { Isalt. Mic. } \\
\text { Topo }\end{array}$ & $\begin{array}{r}\text { Isalt. Mic. } \\
\text { Topo }\end{array}$ \\
\hline Prof. (m) & 127,00 & 127,00 & 127,00 & 127,00 & 127,00 & 127,00 & 127,00 & 127,00 & 127,00 & 127,00 & 127,00 & 127,00 & 127,00 & 127,00 & 127,00 & 127,00 \\
\hline Análise & 1 & 2 & 3 & 4 & 5 & 6 & 7 & 8 & 9 & 10 & 11 & 12 & 13 & 14 & 15 & 16 \\
\hline $\mathrm{SiO}_{2}$ & 0,14 & 0,03 & 0,06 & 0,13 & 0,20 & 0,00 & 0,01 & 0,04 & 0,05 & 0,00 & 0,01 & 0,02 & 0,02 & 0,00 & 0,00 & 0,07 \\
\hline $\mathrm{ThO}_{2}$ & 0,04 & 0,00 & 0,62 & 0,01 & 0,02 & 1,66 & 0,50 & 1,30 & 1,35 & 1,56 & 0,99 & 0,34 & 0,62 & 1,47 & 0,84 & 0,94 \\
\hline $\mathrm{Al}_{2} \mathrm{O}_{3}$ & 0,81 & 0,66 & 1,05 & 1,08 & 0,88 & 0,93 & 0,83 & 0,77 & 0,42 & 0,79 & 0,81 & 0,87 & 0,92 & 1,02 & 0,81 & 0,75 \\
\hline $\mathrm{FeO}$ & 0,99 & 0,61 & 0,20 & 0,04 & 0,12 & 0,12 & 1,20 & 0,43 & 0,31 & 0,66 & 0,59 & 0,75 & 0,74 & 0,36 & 0,54 & 0,69 \\
\hline $\mathrm{MnO}$ & 0,00 & 0,00 & 0,00 & 0,00 & 0,06 & 0,00 & 0,00 & 0,00 & 0,00 & 0,00 & 0,00 & 0,00 & 0,00 & 0,04 & 0,13 & 0,15 \\
\hline $\mathrm{CaO}$ & 9,06 & 9,95 & 9,98 & 8,44 & 9,37 & 9,97 & 10,76 & 8,43 & 5,44 & 7,66 & 9,79 & 10,33 & 10,81 & 9,87 & 9,79 & 6,68 \\
\hline $\mathrm{BaO}$ & 0,00 & 0,13 & 0,00 & 0,00 & 0,00 & 0,00 & 0,00 & 0,00 & 0,00 & 0,00 & 0,00 & 0,00 & 0,00 & 0,00 & 0,00 & 0,00 \\
\hline $\mathrm{SrO}$ & 0,64 & 0,42 & 1,01 & 0,66 & 0,56 & 0,71 & 0,37 & 0,56 & 0,33 & 0,35 & 0,58 & 0,69 & 0,62 & 0,80 & 0,49 & 0,38 \\
\hline $\mathrm{PbO}$ & 0,00 & 0,06 & 0,00 & 0,00 & 0,12 & 0,11 & 0,01 & 0,19 & 0,10 & 0,12 & 0,00 & 0,00 & 0,00 & 0,00 & 0,04 & 0,25 \\
\hline $\mathrm{P}_{2} \mathrm{O}_{5}$ & 20,35 & 23,25 & 26,19 & 23,23 & 25,17 & 26,96 & 27,44 & 24,12 & 20,80 & 21,65 & 20,35 & 26,93 & 23,64 & 23,42 & 20,82 & 20,56 \\
\hline $\mathrm{La}_{2} \mathrm{O}_{3}$ & 15,09 & 14,19 & 19,21 & 15,90 & 15,89 & 12,08 & 12,54 & 14,78 & 23,95 & 17,14 & 13,73 & 12,56 & 12,38 & 12,40 & 15,74 & 14,92 \\
\hline $\mathrm{Ce}_{2} \mathrm{O}_{3}$ & 29,56 & 24,73 & 22,48 & 18,97 & 22,89 & 20,71 & 20,78 & 20,50 & 20,08 & 25,05 & 22,81 & 20,24 & 18,76 & 19,55 & 33,84 & 21,89 \\
\hline $\mathrm{Pr}_{2} \mathrm{O}_{3}$ & 2,55 & 2,26 & 2,17 & 2,10 & 2,03 & 2,17 & 1,99 & 2,44 & 3,12 & 2,45 & 2,16 & 2,12 & 2,02 & 2,03 & 2,48 & 2,39 \\
\hline $\mathrm{Nd}_{2} \mathrm{O}_{3}$ & 12,10 & 11,03 & 9,17 & 7,64 & 8,82 & 9,11 & 8,46 & 9,53 & 13,45 & 10,51 & 9,85 & 9,98 & 8,93 & 8,73 & 10,17 & 9,67 \\
\hline $\mathrm{Sm}_{2} \mathrm{O}_{3}$ & 0,00 & 0,27 & 0,39 & 0,30 & 0,57 & 0,66 & 0,00 & 0,51 & 0,00 & 0,35 & 0,47 & 0,32 & 0,32 & 0,40 & 0,00 & 0,28 \\
\hline $\mathrm{Eu}_{2} \mathrm{O}_{3}$ & 0,86 & 0,79 & 0,73 & 0,56 & 0,56 & 0,70 & 0,55 & 0,72 & 0,93 & 0,67 & 0,55 & 0,65 & 0,57 & 0,68 & 0,70 & 0,55 \\
\hline $\mathrm{Gd}_{2} \mathrm{O}_{3}$ & 2,40 & 1,95 & 1,60 & 1,60 & 1,68 & 1,62 & 1,72 & 1,57 & 1,35 & 1,93 & 1,57 & 1,79 & 1,44 & 1,54 & 2,82 & 1,70 \\
\hline $\mathrm{Dy}_{2} \mathrm{O}_{3}$ & 0,00 & 0,08 & 0,21 & 0,20 & 0,00 & 0,00 & 0,12 & 0,08 & 0,00 & 0,01 & 0,00 & 0,06 & 0,16 & 0,12 & 0,00 & 0,00 \\
\hline $\mathrm{Y}_{2} \mathrm{O}_{3}$ & 0,00 & 0,00 & 0,00 & 0,00 & 0,00 & 0,00 & 0,00 & 0,00 & 0,00 & 0,00 & 0,00 & 0,00 & 0,00 & 0,00 & 0,00 & 0,00 \\
\hline $\mathrm{F}$ & 1,14 & 0,38 & 0,92 & 1,23 & 1,28 & 1,25 & 1,01 & 1,10 & 0,91 & 1,29 & 1,33 & 0,85 & 1,06 & 0,98 & 1,04 & 1,95 \\
\hline $\mathrm{Cl}$ & 0,06 & 0,11 & 0,01 & 0,14 & 0,00 & 0,00 & 0,03 & 0,03 & 0,03 & 0,05 & 0,03 & 0,06 & 0,01 & 0,03 & 0,04 & 0,04 \\
\hline TOTAL & 96,13 & 91,32 & 96,47 & 82,82 & 90,76 & 89,10 & 88,66 & 87,61 & 93,60 & 92,85 & 85,92 & 88,88 & 83,47 & 83,72 & 100,93 & 84,42 \\
\hline $\mathrm{ETR}_{2} \mathrm{O}_{3}$ & 62,56 & 55,34 & 56,02 & 47,26 & 52,45 & 47,05 & 46,23 & 50,12 & 63,01 & 58,26 & 51,13 & 47,76 & 44,68 & 45,46 & 65,87 & 51,49 \\
\hline
\end{tabular}

Análises 1-16: monazita pseudomórfica. 
Análises WDS de Monazita (I) - continuação.

\begin{tabular}{|c|c|c|c|c|c|c|c|c|c|c|c|c|c|c|c|c|}
\hline Rocha & Beb. & Beb. & Beb. & Beb. & Beb. & Beb. & Beb. & Beb. & Beb. & Beb. & Beb. & Beb. & Beb. & Beb. & Beb. & Beb. \\
\hline Intemp. & $\begin{array}{r}\text { Isalt. Mic. } \\
\text { Topo }\end{array}$ & $\begin{array}{r}\text { Isalt. Mic. } \\
\text { Topo }\end{array}$ & $\begin{array}{r}\text { Isalt. Mic. } \\
\text { Topo }\end{array}$ & $\begin{array}{r}\text { Isalt. Mic. } \\
\text { Topo }\end{array}$ & $\begin{array}{r}\text { Isalt. Mic. } \\
\text { Topo }\end{array}$ & $\begin{array}{r}\text { Isalt. Mic. } \\
\text { Topo }\end{array}$ & $\begin{array}{r}\text { Isalt. Mic. } \\
\text { Topo }\end{array}$ & $\begin{array}{r}\text { Isalt. Mic. } \\
\text { Topo }\end{array}$ & $\begin{array}{r}\text { Isalt. Mic. } \\
\text { Topo }\end{array}$ & $\begin{array}{r}\text { Isalt. Mic. } \\
\text { Topo }\end{array}$ & $\begin{array}{r}\text { Isalt. Mic. } \\
\text { Topo }\end{array}$ & $\begin{array}{r}\text { Isalt. Mic. } \\
\text { Topo }\end{array}$ & $\begin{array}{r}\text { Isalt. Mic. } \\
\text { Topo }\end{array}$ & $\begin{array}{r}\text { Isalt. Mic. } \\
\text { Topo }\end{array}$ & $\begin{array}{r}\text { Isalt. Mic. } \\
\text { Topo }\end{array}$ & $\begin{array}{r}\text { Isalt. Mic. } \\
\text { Topo }\end{array}$ \\
\hline Prof. (m) & 127,00 & 127,00 & 127,00 & 127,00 & 127,00 & 127,00 & 127,00 & 127,00 & 127,00 & 127,00 & 127,00 & 127,00 & 127,00 & 127,00 & 127,00 & 127,00 \\
\hline Análise & 1 & 2 & 3 & 4 & 5 & 6 & 7 & 8 & 9 & 10 & 11 & 12 & 13 & 14 & 15 & 16 \\
\hline $\mathrm{Si}$ & 0,006 & 0,001 & 0,002 & 0,006 & 0,008 & - & - & 0,002 & 0,002 & - & 0,001 & 0,001 & 0,001 & - & - & 0,003 \\
\hline Th & - & - & 0,006 & - & - & 0,015 & 0,005 & 0,013 & 0,014 & 0,015 & 0,010 & 0,003 & 0,006 & 0,015 & 0,008 & 0,010 \\
\hline $\mathrm{Al}$ & 0,042 & 0,033 & 0,049 & 0,057 & 0,043 & 0,044 & 0,039 & 0,039 & 0,022 & 0,041 & 0,044 & 0,042 & 0,048 & 0,053 & 0,040 & 0,042 \\
\hline $\mathrm{Fe}^{2}$ & 0,036 & 0,022 & 0,007 & 0,002 & 0,004 & 0,004 & 0,040 & 0,016 & 0,012 & 0,024 & 0,023 & 0,025 & 0,027 & 0,013 & 0,019 & 0,027 \\
\hline Mn & - & - & - & - & 0,002 & - & - & - & - & - & - & - & - & 0,001 & 0,005 & 0,006 \\
\hline $\mathrm{Ca}$ & 0,422 & 0,458 & 0,421 & 0,405 & 0,414 & 0,433 & 0,463 & 0,390 & 0,263 & 0,359 & 0,484 & 0,449 & 0,509 & 0,469 & 0,440 & 0,335 \\
\hline $\mathrm{Ba}$ & - & 0,002 & - & - & - & - & - & - & - & - & - & - & - & - & - & - \\
\hline $\mathrm{Sr}$ & 0,016 & 0,010 & 0,023 & 0,017 & 0,013 & 0,017 & 0,009 & 0,014 & 0,009 & 0,009 & 0,015 & 0,016 & 0,016 & 0,021 & 0,012 & 0,010 \\
\hline $\mathrm{Pb}$ & - & 0,001 & - & - & 0,001 & 0,001 & - & 0,002 & 0,001 & 0,001 & - & - & - & - & - & 0,003 \\
\hline $\mathrm{P}$ & 0,748 & 0,845 & 0,873 & 0,880 & 0,878 & 0,925 & 0,932 & 0,883 & 0,795 & 0,803 & 0,795 & 0,925 & 0,880 & 0,881 & 0,739 & 0,816 \\
\hline $\mathrm{La}$ & 0,242 & 0,225 & 0,279 & 0,262 & 0,242 & 0,181 & 0,186 & 0,236 & 0,399 & 0,277 & 0,234 & 0,188 & 0,201 & 0,203 & 0,243 & 0,258 \\
\hline $\mathrm{Ce}$ & 0,470 & 0,389 & 0,324 & 0,311 & 0,345 & 0,307 & 0,305 & 0,324 & 0,332 & 0,402 & 0,385 & 0,301 & 0,302 & 0,318 & 0,519 & 0,376 \\
\hline $\operatorname{Pr}$ & 0,040 & 0,035 & 0,031 & 0,034 & 0,030 & 0,032 & 0,029 & 0,038 & 0,051 & 0,039 & 0,036 & 0,031 & 0,032 & 0,033 & 0,038 & 0,041 \\
\hline $\mathrm{Nd}$ & 0,188 & 0,169 & 0,129 & 0,122 & 0,130 & 0,132 & 0,121 & 0,147 & 0,217 & 0,164 & 0,162 & 0,145 & 0,140 & 0,138 & 0,152 & 0,162 \\
\hline Sm & - & 0,004 & 0,005 & 0,005 & 0,008 & 0,009 & - & 0,008 & - & 0,005 & 0,007 & 0,004 & 0,005 & 0,006 & - & 0,005 \\
\hline $\mathrm{Eu}$ & 0,013 & 0,012 & 0,010 & 0,008 & 0,008 & 0,010 & 0,007 & 0,011 & 0,014 & 0,010 & 0,009 & 0,009 & 0,009 & 0,010 & 0,010 & 0,009 \\
\hline $\mathrm{Gd}$ & 0,035 & 0,028 & 0,021 & 0,024 & 0,023 & 0,022 & 0,023 & 0,023 & 0,020 & 0,028 & 0,024 & 0,024 & 0,021 & 0,023 & 0,039 & 0,026 \\
\hline Dy & - & 0,001 & 0,003 & 0,003 & - & - & 0,002 & 0,001 & - & - & - & 0,001 & 0,002 & 0,002 & - & - \\
\hline Y & - & - & - & - & - & - & - & - & - & - & - & - & - & - & - & - \\
\hline Cations & 2,271 & 2,248 & 2,194 & 2,158 & 2,169 & 2,143 & 2,172 & 2,164 & 2,182 & 2,196 & 2,242 & 2,177 & 2,215 & 2,197 & 2,285 & 2,147 \\
\hline
\end{tabular}

Análises 1-16: monazita pseudomórfica. 
Análises WDS de Monazita (II).

\begin{tabular}{|c|c|c|c|c|c|c|c|c|c|c|c|c|c|c|c|c|}
\hline Rocha & Beb. & Beb. & Beb. & Beb. & Beb. & Beb. & Beb. & Beb. & Beb. & Beb. & Beb. & Beb. & Beb. & Beb. & Beb. & Beb. \\
\hline Intemp. & $\begin{array}{r}\text { Isalt. Mic. } \\
\text { Topo }\end{array}$ & $\begin{array}{r}\text { Isalt. Mic. } \\
\text { Topo }\end{array}$ & $\begin{array}{r}\text { Isalt. Mic. } \\
\text { Topo }\end{array}$ & Alot. Base & Alot. Base & Alot. Base & Alot. Base & Alot. Base & Alot. Base & Alot. Base & Alot. Base & Alot. Base & Alot. Base & Alot. Base & Alot. Base & Alot. Base \\
\hline Prof. (m) & 127,00 & 127,00 & 127,00 & 117,00 & 117,00 & 117,00 & 117,00 & 117,00 & 117,00 & 117,00 & 117,00 & 117,00 & 117,00 & 117,00 & 117,00 & 80,25 \\
\hline Análise & 17 & 18 & 19 & 20 & 21 & 22 & 23 & 24 & 25 & 26 & 27 & 28 & 29 & 30 & 31 & 32 \\
\hline $\mathrm{SiO}_{2}$ & 0,00 & 0,00 & 0,02 & 0,00 & 0,00 & 0,00 & 0,01 & 0,02 & 0,00 & 0,22 & 0,03 & 0,00 & 0,00 & 0,00 & 0,00 & 0,00 \\
\hline $\mathrm{ThO}_{2}$ & 0,17 & 0,25 & 0,51 & 0,04 & 0,05 & 0,10 & 0,01 & 0,09 & 0,00 & 0,04 & 0,03 & 0,00 & 0,00 & 0,02 & 0,01 & 0,02 \\
\hline $\mathrm{Al}_{2} \mathrm{O}_{3}$ & 0,78 & 0,98 & 0,81 & 0,20 & 0,12 & 0,16 & 0,35 & 0,12 & 0,02 & 0,11 & 0,17 & 0,53 & 0,13 & 0,06 & 0,11 & 0,05 \\
\hline $\mathrm{FeO}$ & 2,21 & 0,41 & 0,03 & 0,12 & 0,07 & 0,11 & 1,39 & 0,40 & 0,69 & 0,14 & 1,20 & 0,41 & 0,09 & 0,08 & 0,14 & 0,45 \\
\hline $\mathrm{MnO}$ & 0,00 & 0,00 & 0,00 & 0,00 & 0,00 & 0,00 & 0,00 & 0,00 & 0,00 & 0,00 & 0,00 & 0,16 & 0,00 & 0,00 & 0,00 & 0,00 \\
\hline $\mathrm{CaO}$ & 9,65 & 9,72 & 9,04 & 6,11 & 7,14 & 5,83 & 4,93 & 6,69 & 7,39 & 6,36 & 7,33 & 5,35 & 6,59 & 7,04 & 7,05 & 1,60 \\
\hline $\mathrm{BaO}$ & 0,00 & 0,00 & 0,00 & 0,00 & 0,00 & 0,00 & 0,00 & 0,00 & 0,00 & 0,00 & 0,00 & 0,00 & 0,00 & 0,00 & 0,00 & 0,00 \\
\hline $\mathrm{SrO}$ & 0,51 & 0,58 & 0,85 & 0,00 & 0,13 & 0,13 & 0,09 & 0,00 & 0,00 & 0,02 & 0,11 & 0,03 & 0,10 & 0,14 & 0,01 & 1,13 \\
\hline $\mathrm{PbO}$ & 0,01 & 0,00 & 0,00 & 0,00 & 0,00 & 0,00 & 0,00 & 0,00 & 0,00 & 0,02 & 0,14 & 0,00 & 0,03 & 0,00 & 0,00 & 0,00 \\
\hline $\mathrm{P}_{2} \mathrm{O}_{5}$ & 25,66 & 26,01 & 25,27 & 25,56 & 25,88 & 27,96 & 21,94 & 26,26 & 25,88 & 24,85 & 26,67 & 20,34 & 26,97 & 27,03 & 26,30 & 22,20 \\
\hline $\mathrm{La}_{2} \mathrm{O}_{3}$ & 14,21 & 17,45 & 19,44 & 10,74 & 17,90 & 17,55 & 5,66 & 8,98 & 15,98 & 8,32 & 15,76 & 8,96 & 8,62 & 18,56 & 7,64 & 10,33 \\
\hline $\mathrm{Ce}_{2} \mathrm{O}_{3}$ & 24,18 & 24,77 & 28,18 & 22,86 & 13,50 & 11,22 & 19,26 & 23,47 & 19,21 & 13,60 & 18,10 & 23,33 & 23,03 & 13,91 & 25,45 & 24,37 \\
\hline $\mathrm{Pr}_{2} \mathrm{O}_{3}$ & 2,21 & 2,17 & 2,33 & 2,08 & 3,32 & 3,20 & 1,31 & 1,66 & 2,18 & 1,08 & 2,22 & 1,43 & 1,74 & 2,63 & 1,76 & 3,17 \\
\hline $\mathrm{Nd}_{2} \mathrm{O}_{3}$ & 8,34 & 8,40 & 9,31 & 10,12 & 14,90 & 15,64 & 7,39 & 9,97 & 10,44 & 5,57 & 10,49 & 8,67 & 10,36 & 12,45 & 10,33 & 17,15 \\
\hline $\mathrm{Sm}_{2} \mathrm{O}_{3}$ & 0,00 & 0,13 & 0,60 & 1,04 & 1,45 & 1,83 & 0,00 & 1,26 & 0,95 & 0,42 & 0,00 & 0,82 & 1,22 & 0,82 & 1,24 & 1,70 \\
\hline $\mathrm{Eu}_{2} \mathrm{O}_{3}$ & 0,70 & 0,64 & 0,62 & 0,88 & 1,21 & 1,36 & 0,64 & 0,94 & 0,84 & 0,49 & 0,85 & 0,59 & 1,07 & 1,15 & 0,98 & 1,24 \\
\hline $\mathrm{Gd}_{2} \mathrm{O}_{3}$ & 1,71 & 1,83 & 2,11 & 2,25 & 1,56 & 1,64 & 2,11 & 2,99 & 2,11 & 1,54 & 1,82 & 2,42 & 2,73 & 1,82 & 2,73 & 2,33 \\
\hline $\mathrm{Dy}_{2} \mathrm{O}_{3}$ & 0,00 & 0,08 & 0,14 & 0,00 & 0,00 & 0,00 & 0,00 & 0,00 & 0,00 & 0,00 & 0,00 & 0,00 & 0,00 & 0,00 & 0,00 & 0,15 \\
\hline $\mathrm{Y}_{2} \mathrm{O}_{3}$ & 0,00 & 0,00 & 0,00 & 0,00 & 0,00 & 0,00 & 0,00 & 0,00 & 0,00 & 0,00 & 0,00 & 0,00 & 0,00 & 0,00 & 0,00 & 0,00 \\
\hline $\mathrm{F}$ & 1,00 & 1,11 & 1,09 & 1,17 & 0,66 & 0,28 & 1,98 & 1,14 & 0,98 & 0,82 & 1,16 & 1,12 & 0,87 & 0,90 & 1,10 & 1,23 \\
\hline $\mathrm{Cl}$ & 0,06 & 0,02 & 0,01 & 0,05 & 0,06 & 0,13 & 0,09 & 0,10 & 0,09 & 0,36 & 0,02 & 0,13 & 0,03 & 0,08 & 0,03 & 0,10 \\
\hline TOTAL & 92,16 & 95,10 & 100,91 & 89,95 & 89,40 & 90,22 & 87,50 & 84,36 & 87,21 & 64,91 & 87,05 & 90,24 & 87,25 & 88,10 & 89,54 & 87,62 \\
\hline $\mathrm{ETR}_{2} \mathrm{O}_{3}$ & 51,52 & 55,47 & 62,84 & 49,98 & 53,83 & 52,44 & 36,35 & 49,27 & 51,69 & 31,02 & 49,24 & 46,21 & 48,78 & 51,34 & 50,13 & 60,67 \\
\hline
\end{tabular}

Análises 17-32: monazita pseudomórfica. 
Análises WDS de Monazita (II) - continuação.

\begin{tabular}{|c|c|c|c|c|c|c|c|c|c|c|c|c|c|c|c|c|}
\hline Rocha & Beb. & Beb. & Beb. & Beb. & Beb. & Beb. & Beb. & Beb. & Beb. & Beb. & Beb. & Beb. & Beb. & Beb. & Beb. & Beb. \\
\hline Intemp. & $\begin{array}{r}\text { Isalt. Mic. } \\
\text { Topo }\end{array}$ & $\begin{array}{r}\text { Isalt. Mic. } \\
\text { Topo }\end{array}$ & $\begin{array}{r}\text { Isalt. Mic. } \\
\text { Topo }\end{array}$ & Alot. Base & Alot. Base & Alot. Base & Alot. Base & Alot. Base & Alot. Base & Alot. Base & Alot. Base & Alot. Base & Alot. Base & Alot. Base & Alot. Base & Alot. Base \\
\hline Prof. (m) & 127,00 & 127,00 & 127,00 & 117,00 & 117,00 & 117,00 & 117,00 & 117,00 & 117,00 & 117,00 & 117,00 & 117,00 & 117,00 & 117,00 & 117,00 & 80,25 \\
\hline Análise & 17 & 18 & 19 & 20 & 21 & 22 & 23 & 24 & 25 & 26 & 27 & 28 & 29 & 30 & 31 & 32 \\
\hline $\mathrm{Si}$ & - & - & 0,001 & - & - & - & - & 0,001 & - & 0,011 & 0,001 & - & - & - & - & - \\
\hline Th & 0,002 & 0,002 & 0,005 & - & - & 0,001 & - & 0,001 & - & - & - & - & - & - & - & - \\
\hline $\mathrm{Al}$ & 0,037 & 0,046 & 0,038 & 0,009 & 0,006 & 0,008 & 0,015 & 0,006 & 0,001 & 0,006 & 0,008 & 0,025 & 0,006 & 0,003 & 0,005 & 0,003 \\
\hline $\mathrm{Fe}^{2}$ & 0,075 & 0,014 & 0,001 & 0,004 & 0,002 & 0,004 & 0,044 & 0,015 & 0,025 & 0,006 & 0,042 & 0,013 & 0,003 & 0,003 & 0,005 & 0,018 \\
\hline Mn & - & - & - & - & - & - & - & - & - & - & - & 0,005 & - & - & - & - \\
\hline $\mathrm{Ca}$ & 0,419 & 0,414 & 0,380 & 0,262 & 0,322 & 0,251 & 0,198 & 0,311 & 0,338 & 0,341 & 0,328 & 0,227 & 0,289 & 0,313 & 0,304 & 0,081 \\
\hline $\mathrm{Ba}$ & - & - & - & - & - & - & - & - & - & - & - & - & - & - & - & - \\
\hline $\mathrm{Sr}$ & 0,012 & 0,013 & 0,019 & - & 0,003 & 0,003 & 0,002 & - & - & - & 0,003 & 0,001 & 0,002 & 0,003 & - & 0,031 \\
\hline $\mathrm{Pb}$ & - & - & - & - & - & - & - & - & - & - & 0,002 & - & - & - & - & - \\
\hline $\mathrm{P}$ & 0,881 & 0,875 & 0,840 & 0,865 & 0,922 & 0,954 & 0,695 & 0,964 & 0,936 & 1,053 & 0,944 & 0,682 & 0,936 & 0,950 & 0,897 & 0,885 \\
\hline $\mathrm{La}$ & 0,212 & 0,256 & 0,281 & 0,158 & 0,278 & 0,261 & 0,078 & 0,144 & 0,252 & 0,154 & 0,243 & 0,131 & 0,130 & 0,284 & 0,114 & 0,179 \\
\hline $\mathrm{Ce}$ & 0,359 & 0,360 & 0,405 & 0,334 & 0,208 & 0,165 & 0,264 & 0,372 & 0,300 & 0,249 & 0,277 & 0,338 & 0,346 & 0,212 & 0,375 & 0,420 \\
\hline $\operatorname{Pr}$ & 0,033 & 0,031 & 0,033 & 0,030 & 0,051 & 0,047 & 0,018 & 0,026 & 0,034 & 0,020 & 0,034 & 0,021 & 0,026 & 0,040 & 0,026 & 0,054 \\
\hline $\mathrm{Nd}$ & 0,121 & 0,119 & 0,130 & 0,144 & 0,224 & 0,225 & 0,099 & 0,154 & 0,159 & 0,100 & 0,157 & 0,123 & 0,152 & 0,185 & 0,149 & 0,288 \\
\hline Sm & - & 0,002 & 0,008 & 0,014 & 0,021 & 0,025 & - & 0,019 & 0,014 & 0,007 & - & 0,011 & 0,017 & 0,012 & 0,017 & 0,028 \\
\hline $\mathrm{Eu}$ & 0,010 & 0,009 & 0,008 & 0,012 & 0,017 & 0,019 & 0,008 & 0,014 & 0,012 & 0,008 & 0,012 & 0,008 & 0,015 & 0,016 & 0,013 & 0,020 \\
\hline $\mathrm{Gd}$ & 0,023 & 0,024 & 0,027 & 0,030 & 0,022 & 0,022 & 0,026 & 0,043 & 0,030 & 0,026 & 0,025 & 0,032 & 0,037 & 0,025 & 0,036 & 0,036 \\
\hline Dy & - & 0,001 & 0,002 & - & - & - & - & - & - & - & - & - & - & - & - & 0,002 \\
\hline Y & - & - & - & - & - & - & - & - & - & - & - & - & - & - & - & - \\
\hline Cations & 2,205 & 2,183 & 2,194 & 2,065 & 2,122 & 2,076 & 2,014 & 2,080 & 2,118 & 2,016 & 2,105 & 2,090 & 2,072 & 2,089 & 2,081 & 2,055 \\
\hline
\end{tabular}

Análises 17-32: monazita pseudomórfica. 
Análises WDS de Monazita (III).

\begin{tabular}{lrrrrrrr}
\hline Rocha & Beb. & Beb. & Beb. & Beb. & Beb. & Beb. & Beb. \\
\hline Intemp. & Alot. Base & Alot. Base & Alot. Base & Alot. Base & Alot. Base & Alot. Base & Alot. Base \\
\hline Prof. (m) & 80,25 & 80,25 & 80,25 & 80,25 & 80,25 & 80,25 & 80,25 \\
\hline Análise & 33 & 34 & 35 & 36 & 37 & 38 & 39 \\
\hline $\mathrm{SiO}_{2}$ & 0,00 & 0,00 & 0,02 & 0,08 & 0,04 & 0,00 & 0,00 \\
$\mathrm{ThO}_{2}$ & 0,01 & 0,04 & 0,31 & 4,27 & 3,55 & 4,00 & 2,07 \\
$\mathrm{Al}_{2} \mathrm{O}_{3}$ & 0,00 & 0,01 & 4,60 & 0,05 & 0,03 & 0,05 & 0,18 \\
$\mathrm{FeO}$ & 0,36 & 0,62 & 0,86 & 0,76 & 0,18 & 0,55 & 0,52 \\
$\mathrm{MnO}$ & 0,00 & 0,00 & 0,00 & 0,42 & 0,27 & 0,11 & 2,92 \\
$\mathrm{CaO}$ & 1,74 & 2,36 & 1,63 & 1,29 & 1,18 & 1,41 & 1,14 \\
$\mathrm{BaO}$ & 0,00 & 0,00 & 0,00 & 0,48 & 0,00 & 0,00 & 1,12 \\
$\mathrm{SrO}_{\mathrm{OaO}}$ & 1,06 & 1,46 & 1,13 & 1,63 & 1,82 & 1,90 & 1,55 \\
$\mathrm{PbO}$ & 0,00 & 0,00 & 0,00 & 0,00 & 0,06 & 0,00 & 0,07 \\
$\mathrm{P}_{2} \mathrm{O}_{5}$ & 22,69 & 23,81 & 21,51 & 22,22 & 23,23 & 21,29 & 20,85 \\
$\mathrm{La}_{2} \mathrm{O}_{3}$ & 10,20 & 9,81 & 17,37 & 12,92 & 11,70 & 13,06 & 14,55 \\
$\mathrm{Ce}_{2} \mathrm{O}_{3}$ & 24,52 & 24,97 & 25,59 & 23,97 & 22,43 & 23,59 & 25,55 \\
$\mathrm{Pr}_{2} \mathrm{O}_{3}$ & 3,39 & 3,20 & 2,60 & 2,40 & 2,36 & 2,23 & 2,27 \\
$\mathrm{Nd}_{2} \mathrm{O}_{3}$ & 17,27 & 17,35 & 10,20 & 10,91 & 10,22 & 10,88 & 10,00 \\
$\mathrm{Sm}_{2} \mathrm{O}_{3}$ & 2,14 & 0,00 & 0,00 & 0,72 & 0,00 & 1,10 & 0,35 \\
$\mathrm{Eu}_{2} \mathrm{O}_{3}$ & 1,36 & 1,13 & 0,76 & 0,82 & 0,72 & 0,81 & 0,66 \\
$\mathrm{Gd}_{2} \mathrm{O}_{3}$ & 2,36 & 2,43 & 2,02 & 2,14 & 2,01 & 1,94 & 1,91 \\
$\mathrm{Dy}_{2} \mathrm{O}_{3}$ & 0,11 & 0,00 & 0,00 & 0,04 & 0,00 & 0,00 & 0,34 \\
$\mathrm{Y}_{2} \mathrm{O}_{3}$ & 0,05 & 0,00 & 0,00 & 0,00 & 0,00 & 0,00 & 0,00 \\
$\mathrm{~F}$ & 1,31 & 1,47 & 1,32 & 0,88 & 0,95 & 0,87 & 1,07 \\
$\mathrm{Cl}$ & 0,06 & 0,08 & 0,03 & 0,09 & 0,10 & 0,14 & 0,09 \\
$\mathrm{TOTAL}_{\mathrm{ETR}_{2} \mathrm{O}_{3}}^{88,85}$ & 89,08 & 90,32 & 86,51 & 81,14 & 84,25 & 87,80 \\
\hline $\mathrm{nali}_{3}$ & 61,59 & 59,21 & 58,55 & 54,07 & 49,45 & 53,71 & 55,72 \\
\hline
\end{tabular}

Análises 33-39: monazita pseudomórfica. 
Análises WDS de Monazita (III) - continuação.

\begin{tabular}{lrrrrrrr}
\hline Rocha & Beb. & Beb. & Beb. & Beb. & Beb. & Beb. & Beb. \\
\hline Intemp. & Alot. Base & Alot. Base & Alot. Base & Alot. Base & Alot. Base & Alot. Base & Alot. Base \\
\hline Prof. (m) & 80,25 & 80,25 & 80,25 & 80,25 & 80,25 & 80,25 & 80,25 \\
\hline Análise & 33 & 34 & 35 & 36 & 37 & 38 & 39 \\
\hline $\mathrm{Si}$ & - & - & 0,001 & 0,004 & 0,002 & - & - \\
$\mathrm{Th}$ & - & - & 0,003 & 0,046 & 0,039 & 0,045 & 0,022 \\
$\mathrm{Al}$ & - & - & 0,237 & 0,003 & 0,002 & 0,003 & 0,010 \\
$\mathrm{Fe}^{2}$ & 0,014 & 0,023 & 0,031 & 0,030 & 0,007 & 0,023 & 0,021 \\
$\mathrm{Mn}$ & - & - & - & 0,017 & 0,011 & 0,005 & 0,118 \\
$\mathrm{Ca}$ & 0,086 & 0,114 & 0,076 & 0,066 & 0,062 & 0,074 & 0,059 \\
$\mathrm{Ba}$ & - & - & - & 0,009 & - & - & 0,021 \\
$\mathrm{Sr}$ & 0,028 & 0,038 & 0,029 & 0,045 & 0,051 & 0,054 & 0,043 \\
$\mathrm{~Pb}$ & - & - & - & - & 0,001 & - & 0,001 \\
$\mathrm{P}$ & 0,890 & 0,907 & 0,797 & 0,896 & 0,954 & 0,889 & 0,845 \\
$\mathrm{La}$ & 0,174 & 0,163 & 0,280 & 0,227 & 0,209 & 0,237 & 0,257 \\
$\mathrm{Ce}$ & 0,416 & 0,411 & 0,410 & 0,418 & 0,398 & 0,426 & 0,448 \\
$\mathrm{Pr}$ & 0,057 & 0,053 & 0,041 & 0,042 & 0,042 & 0,040 & 0,040 \\
$\mathrm{Nd}$ & 0,286 & 0,279 & 0,159 & 0,186 & 0,177 & 0,192 & 0,171 \\
$\mathrm{Sm}$ & 0,034 & - & - & 0,012 & - & 0,019 & 0,006 \\
$\mathrm{Eu}$ & 0,022 & 0,017 & 0,011 & 0,013 & 0,012 & 0,014 & 0,011 \\
$\mathrm{Gd}$ & 0,036 & 0,036 & 0,029 & 0,034 & 0,032 & 0,032 & 0,030 \\
$\mathrm{Dy}$ & 0,002 & - & - & 0,001 & - & - & 0,005 \\
$\mathrm{Y}$ & 0,001 & - & - & - & - & - & - \\
$\mathrm{Cations}$ & 2,051 & 2,048 & 2,118 & 2,060 & 2,009 & 2,062 & 2,130 \\
\hline
\end{tabular}

Análises 33-39: monazita pseudomórfica. 
Análises EDS de Monazita.

\begin{tabular}{|c|c|c|c|c|c|c|c|c|c|c|c|c|c|c|}
\hline Rocha & Carb.. & Beb. & Beb. & Beb. & Beb. & Beb. & Beb. & Beb. & Beb. & Beb. & Beb. & Beb. & Fosc. & Fosc. \\
\hline Intemp. & $\begin{array}{r}\text { Isalt. Mic. } \\
\text { Topo }\end{array}$ & $\begin{array}{r}\text { Isalt. Mic. } \\
\text { Topo }\end{array}$ & $\begin{array}{r}\text { Isalt. Mic. } \\
\text { Topo }\end{array}$ & Alot. Base & Alot. Base & Alot. Base & Alot. Base & Alot. Base & Alot. Base & Alot. Base & Alot. Base & Alot. Base & Alot. Base & Alot. Base \\
\hline Prof. (m) & 166,50 & 106,50 & 106,50 & 106,50 & 106,60 & 106,60 & 106,60 & 106,60 & 106,60 & 106,60 & 106,60 & 106,60 & 165,10 & 165,10 \\
\hline Análise & 40 & 41 & 42 & 43 & 44 & 45 & 46 & 47 & 48 & 49 & 50 & 51 & 52 & 53 \\
\hline $\mathrm{SiO}_{2}$ & 0,00 & 0,00 & 0,00 & 0,00 & 0,00 & 0,00 & 0,00 & 0,00 & 0,00 & 0,00 & 0,00 & 0,00 & 0,00 & 0,00 \\
\hline $\mathrm{ThO}_{2}$ & 0,00 & 0,00 & 0,00 & 0,00 & 0,00 & 0,00 & 0,00 & 0,00 & 0,00 & 0,00 & 0,00 & 0,00 & 0,00 & 0,00 \\
\hline $\mathrm{Al}_{2} \mathrm{O}_{3}$ & 0,00 & 0,00 & 0,00 & 0,00 & 0,00 & 0,00 & 0,00 & 0,00 & 0,00 & 0,00 & 0,00 & 0,00 & 0,00 & 0,00 \\
\hline $\mathrm{FeO}$ & 0,00 & 0,00 & 0,00 & 0,00 & 0,00 & 0,00 & 0,00 & 0,00 & 0,00 & 0,00 & 0,00 & 0,00 & 0,00 & 0,00 \\
\hline $\mathrm{MnO}$ & 0,00 & 0,00 & 0,00 & 0,00 & 0,00 & 0,00 & 0,00 & 0,00 & 0,00 & 0,00 & 0,00 & 0,00 & 0,00 & 0,00 \\
\hline $\mathrm{CaO}$ & 3,18 & 2,57 & 2,53 & 1,76 & 7,10 & 2,05 & 6,87 & 3,74 & 2,17 & 7,83 & 2,27 & 9,43 & 5,13 & 5,08 \\
\hline $\mathrm{BaO}$ & 2,71 & 0,00 & 0,00 & 0,00 & 1,07 & 0,00 & 0,00 & 0,00 & 0,00 & 0,00 & 1,61 & 0,00 & 0,00 & 0,00 \\
\hline $\mathrm{SrO}$ & 0,00 & 0,00 & 0,00 & 2,82 & 0,00 & 3,41 & 0,00 & 0,00 & 0,00 & 3,13 & 3,73 & 0,00 & 0,00 & 0,00 \\
\hline $\mathrm{PbO}$ & 0,00 & 0,00 & 0,00 & 0,00 & 0,00 & 0,00 & 0,00 & 0,00 & 0,00 & 0,00 & 0,00 & 0,00 & 0,00 & 0,00 \\
\hline $\mathrm{P}_{2} \mathrm{O}_{5}$ & 28,86 & 32,11 & 30,45 & 29,71 & 32,95 & 29,65 & 32,58 & 29,52 & 30,54 & 33,84 & 27,70 & 35,16 & 25,27 & 24,61 \\
\hline $\mathrm{La}_{2} \mathrm{O}_{3}$ & 15,01 & 17,61 & 17,04 & 18,15 & 14,47 & 16,91 & 12,37 & 16,12 & 18,73 & 14,02 & 19,11 & 12,41 & 34,75 & 29,78 \\
\hline $\mathrm{Ce}_{2} \mathrm{O}_{3}$ & 33,72 & 36,78 & 36,24 & 35,94 & 29,40 & 33,06 & 30,70 & 33,62 & 35,77 & 28,90 & 32,14 & 28,25 & 27,87 & 24,28 \\
\hline $\mathrm{Pr}_{2} \mathrm{O}_{3}$ & 0,00 & 0,00 & 3,56 & 2,65 & 2,55 & 2,44 & 3,38 & 3,30 & 2,72 & 0,00 & 2,73 & 0,00 & 0,00 & 0,00 \\
\hline $\mathrm{Nd}_{2} \mathrm{O}_{3}$ & 13,50 & 10,94 & 10,09 & 8,97 & 8,02 & 10,47 & 10,41 & 11,15 & 10,17 & 8,46 & 8,79 & 9,26 & 6,99 & 16,25 \\
\hline $\mathrm{Sm}_{2} \mathrm{O}_{3}$ & 0,00 & 0,00 & 0,00 & 0,00 & 0,16 & 0,60 & 0,90 & 1,37 & 0,00 & 0,25 & 1,20 & 1,32 & 0,00 & 0,00 \\
\hline $\mathrm{Eu}_{2} \mathrm{O}_{3}$ & 0,00 & 0,00 & 0,00 & 0,00 & 0,00 & 0,00 & 0,00 & 0,00 & 0,00 & 0,00 & 0,00 & 0,00 & 0,00 & 0,00 \\
\hline $\mathrm{Gd}_{2} \mathrm{O}_{3}$ & 0,00 & 0,00 & 0,00 & 0,00 & 0,60 & 0,67 & 0,40 & 1,32 & 0,34 & 0,32 & 0,72 & 0,37 & 0,00 & 0,00 \\
\hline $\mathrm{Dy}_{2} \mathrm{O}_{3}$ & 0,00 & 0,00 & 0,00 & 0,00 & 0,00 & 0,00 & 0,00 & 0,00 & 0,00 & 0,00 & 0,00 & 0,00 & 0,00 & 0,00 \\
\hline $\mathrm{Y}_{2} \mathrm{O}_{3}$ & 0,00 & 0,00 & 0,00 & 0,00 & 0,00 & 0,00 & 0,00 & 0,00 & 0,00 & 0,00 & 0,00 & 0,00 & 0,00 & 0,00 \\
\hline $\mathrm{F}$ & 2,03 & 0 & 0,1 & 0 & 0 & 0,74 & 0 & 0 & 0 & 0 & 0 & 0 & 0 & 0 \\
\hline $\mathrm{Cl}$ & 0 & 0 & 0 & 0 & 0 & 0 & 0 & 0 & 0 & 0 & 0 & 0 & 0 & 0 \\
\hline TOTAL & 100,00 & 100,01 & 100,01 & 100,00 & 100,00 & 100,00 & 99,99 & 100,00 & 100,44 & 100,02 & 100,00 & 100,00 & 100,01 & 100,00 \\
\hline $\mathrm{ETR}_{2} \mathrm{O}_{3}$ & 62,23 & 65,33 & 66,93 & 65,71 & 55,20 & 64,15 & 58,16 & 66,88 & 67,73 & 51,95 & 64,69 & 51,61 & 69,61 & 70,31 \\
\hline
\end{tabular}

Análise 40: monazita associada com Ba e dolomita. Análises 41-45: monazita intercúmulos no perovskita bebedourito metassomatizado por Mg-carbonatito. Análises 46-49 :

monazita substituindo pseudomorficamente calcita no bebedourito metassomatizado por Mg-carbonatito. Análises 50 e 51: monazita metassomática. 
Análises EDS de Monazita - continuação.

\begin{tabular}{|c|c|c|c|c|c|c|c|c|c|c|c|c|c|c|}
\hline Rocha & Carb.. & Beb. & Beb. & Beb. & Beb. & Beb. & Beb. & Beb. & Beb. & Beb. & Beb. & Beb. & Fosc. & Fosc. \\
\hline Intemp. & $\begin{array}{r}\text { Isalt. Mic. } \\
\text { Topo }\end{array}$ & $\begin{array}{r}\text { Isalt. Mic. } \\
\text { Topo }\end{array}$ & $\begin{array}{r}\text { Isalt. Mic. } \\
\text { Topo }\end{array}$ & Alot. Base & Alot. Base & Alot. Base & Alot. Base & Alot. Base & Alot. Base & Alot. Base & Alot. Base & Alot. Base & Alot. Base & Alot. Base \\
\hline Prof. (m) & 166,50 & 106,50 & 106,50 & 106,50 & 106,60 & 106,60 & 106,60 & 106,60 & 106,60 & 106,60 & 106,60 & 106,60 & 165,10 & 165,10 \\
\hline Análise & 40 & 41 & 42 & 43 & 44 & 45 & 46 & 47 & 48 & 49 & 50 & 51 & 52 & 53 \\
\hline $\mathrm{Si}$ & - & - & - & - & - & - & - & - & - & - & - & - & - & - \\
\hline Th & - & - & - & - & - & - & - & - & - & - & - & - & - & - \\
\hline $\mathrm{Al}$ & - & - & - & - & - & - & - & - & - & - & - & - & - & - \\
\hline $\mathrm{Fe}^{2}$ & - & - & - & - & - & - & - & - & - & - & - & - & - & - \\
\hline $\mathrm{Mn}$ & - & - & - & - & - & - & - & - & - & - & - & - & - & - \\
\hline $\mathrm{Ca}$ & 0,131 & 0,103 & 0,104 & 0,074 & 0,275 & 0,085 & 0,268 & 0,156 & 0,089 & 0,298 & 0,098 & 0,349 & 0,226 & 0,227 \\
\hline $\mathrm{Ba}$ & 0,041 & - & - & - & 0,015 & - & - & - & - & - & 0,025 & - & - & - \\
\hline $\mathrm{Sr}$ & - & - & - & 0,064 & - & 0,077 & - & - & - & 0,064 & 0,087 & - & - & - \\
\hline $\mathrm{Pb}$ & - & - & - & - & - & - & - & - & - & - & - & - & - & - \\
\hline $\mathrm{P}$ & 0,940 & 1,021 & 0,992 & 0,982 & 1,008 & 0,973 & 1,004 & 0,972 & 0,994 & 1,017 & 0,945 & 1,029 & 0,880 & 0,868 \\
\hline $\mathrm{La}$ & 0,213 & 0,244 & 0,242 & 0,261 & 0,193 & 0,242 & 0,166 & 0,231 & 0,266 & 0,184 & 0,284 & 0,158 & 0,527 & 0,457 \\
\hline $\mathrm{Ce}$ & 0,475 & 0,506 & 0,510 & 0,514 & 0,389 & 0,469 & 0,409 & 0,478 & 0,503 & 0,376 & 0,474 & 0,358 & 0,420 & 0,370 \\
\hline $\operatorname{Pr}$ & - & - & 0,050 & 0,038 & 0,034 & 0,034 & 0,045 & 0,047 & 0,038 & - & 0,040 & - & - & - \\
\hline $\mathrm{Nd}$ & 0,186 & 0,147 & 0,139 & 0,125 & 0,104 & 0,145 & 0,135 & 0,155 & 0,140 & 0,107 & 0,127 & 0,114 & 0,103 & 0,242 \\
\hline $\mathrm{Sm}$ & - & - & - & - & 0,002 & 0,008 & 0,011 & 0,018 & - & 0,003 & 0,017 & 0,016 & - & - \\
\hline $\mathrm{Eu}$ & - & - & - & - & - & - & - & - & - & - & - & - & - & - \\
\hline $\mathrm{Gd}$ & - & - & - & - & 0,007 & 0,009 & 0,005 & 0,017 & 0,004 & 0,004 & 0,010 & 0,004 & - & - \\
\hline Dy & - & - & - & - & - & - & - & - & - & - & - & - & - & - \\
\hline $\mathrm{Y}$ & - & - & - & - & - & - & - & - & - & - & - & - & - & - \\
\hline Cations & 2,015 & 2,021 & 2,036 & 2,058 & 2,222 & 2,042 & 2,174 & 2,069 & 2,034 & 2,224 & 2,107 & 2,233 & 2,155 & 2,164 \\
\hline
\end{tabular}

Análise 40: monazita associada com Ba e dolomita. Análises 41-45: monazita intercúmulos no perovskita bebedourito metassomatizado por Mg-carbonatito. Análises 46-49 : monazita substituindo pseudomorficamente calcita no bebedourito metassomatizado por Mg-carbonatito. Análises 50 e 51: monazita metassomática. 
Análises WDS de Crandalita.

\begin{tabular}{|c|c|c|c|c|c|c|c|c|c|c|c|c|}
\hline Rocha & Beb. & Beb. & Beb. & Beb. & Beb. & Beb. & Beb. & Beb. & Beb. & Beb. & Beb. & Beb. \\
\hline Intemp & Alot. Base & Alot. Base & Alot. Base & Alot. Base & Alot. Base & Alot. Base & Alot. Base & Alot. Base & Alot. Base & Alot. Base & Alot. Base & Alot. Base \\
\hline Prof. (m) & 88,80 & 88,80 & 88,80 & 88,80 & 88,80 & 80,25 & 80,25 & 80,25 & 80,25 & 80,25 & 80,25 & 80,25 \\
\hline Análise & 1 & 2 & 3 & 4 & 5 & 6 & 7 & 8 & 9 & 10 & 11 & 12 \\
\hline$\overline{\mathrm{SiO}_{2}}$ & 0,41 & n.d. & 2,11 & 0,80 & 1,04 & 6,37 & 5,71 & 4,82 & 0,16 & 2,66 & 3,57 & 2,07 \\
\hline $\mathrm{TiO}_{2}$ & 3,08 & 0,82 & n.d. & 1,32 & n.d. & 2,25 & 1,78 & 2,05 & 0,32 & 1,56 & 1,29 & 1,31 \\
\hline $\mathrm{ZrO}_{2}$ & 0,02 & 0,17 & 0,07 & n.d. & 0,01 & 0,03 & 0,23 & 0,24 & n.d. & 0,09 & 0,29 & 0,06 \\
\hline $\mathrm{ThO}_{2}$ & 0,03 & n.d. & 0,06 & n.d. & n.d. & n.d. & n.d. & 0,03 & 0,07 & n.d. & 0,06 & n.d. \\
\hline $\mathrm{Al}_{2} \mathrm{O}_{3}$ & 33,14 & 32,49 & 31,10 & 31,70 & 31,42 & 29,32 & 30,66 & 29,63 & 32,07 & 29,36 & 31,26 & 30,02 \\
\hline $\mathrm{V}_{2} \mathrm{O}_{3}$ & n.d. & n.d. & n.d. & n.d. & n.d. & n.d. & n.d. & n.d. & n.d. & n.d. & n.d. & n.d. \\
\hline $\mathrm{Cr}_{2} \mathrm{O}_{3}$ & n.d. & n.d. & n.d. & 0,04 & n.d. & 0,04 & n.d. & 0,01 & 0,01 & 0,03 & 0,01 & 0,03 \\
\hline $\mathrm{Fe}_{2} \mathrm{O}_{3}$ & 2,16 & 2,02 & 3,34 & 2,77 & 3,28 & 12,84 & 12,36 & 14,69 & 6,53 & 12,44 & 11,29 & 12,18 \\
\hline $\mathrm{MnO}$ & n.d. & n.d. & n.d. & n.d. & 0,03 & 0,11 & 0,11 & 0,05 & 0,14 & 0,20 & n.d. & 0,14 \\
\hline $\mathrm{MgO}$ & 0,02 & n.d. & n.d. & n.d. & 0,02 & 0,03 & n.d. & 0,04 & 0,03 & n.d. & n.d. & 0,04 \\
\hline $\mathrm{CaO}$ & 5,16 & 5,51 & 4,49 & 4,02 & 4,46 & 2,13 & 2,59 & 2,15 & 2,89 & 2,37 & 2,61 & 2,46 \\
\hline $\mathrm{BaO}$ & 2,96 & 2,64 & 2,85 & 3,54 & 3,39 & 2,77 & 4,48 & 3,32 & 12,32 & 2,86 & 3,11 & 3,43 \\
\hline $\mathrm{SrO}$ & 5,81 & 5,48 & 5,87 & 5,63 & 5,45 & 3,36 & 3,55 & 3,43 & 3,15 & 4,50 & 5,46 & 4,90 \\
\hline $\mathrm{PbO}$ & 0,05 & 0,02 & 0,03 & n.d. & n.d. & n.d. & n.d. & 0,05 & n.d. & n.d. & 0,03 & 0,09 \\
\hline $\mathrm{Na}_{2} \mathrm{O}$ & n.d. & n.d. & 0,01 & 0,01 & 0,05 & 0,04 & 0,02 & 0,06 & 0,08 & 0,07 & 0,01 & 0,03 \\
\hline $\mathrm{K}_{2} \mathrm{O}$ & 0,01 & 0,05 & 0,02 & 0,01 & 0,05 & 0,04 & 0,04 & n.d. & 0,02 & 0,03 & 0,05 & 0,06 \\
\hline $\mathrm{P}_{2} \mathrm{O}_{5}$ & 29,34 & 30,55 & 28,70 & 31,16 & 29,20 & 19,56 & 21,58 & 20,34 & 25,46 & 22,07 & 23,14 & 24,66 \\
\hline $\mathrm{Nb}_{2} \mathrm{O}_{5}$ & 0,07 & 0,04 & n.d. & 0,08 & n.d. & 0,15 & 0,15 & 0,12 & n.d. & 0,09 & 0,14 & 0,16 \\
\hline $\mathrm{Ta}_{2} \mathrm{O}_{5}$ & n.d. & n.d. & n.d. & n.d. & n.d. & n.d. & n.d. & n.d. & n.d. & n.d. & n.d. & n.d. \\
\hline $\mathrm{La}_{2} \mathrm{O}_{3}$ & 0,83 & 1,20 & 0,85 & 1,01 & 1,07 & 0,92 & 0,86 & 0,76 & 0,36 & 1,03 & 0,95 & 0,97 \\
\hline $\mathrm{Ce}_{2} \mathrm{O}_{3}$ & 0,81 & 0,65 & 0,94 & 1,80 & 2,00 & 1,04 & 0,74 & 1,05 & 0,69 & 1,22 & 1,17 & 1,26 \\
\hline $\mathrm{Pr}_{2} \mathrm{O}_{3}$ & 0,22 & 0,26 & 0,11 & 0,19 & 0,22 & 0,15 & 0,16 & 0,17 & 0,04 & 0,15 & 0,15 & 0,17 \\
\hline $\mathrm{Nd}_{2} \mathrm{O}_{3}$ & 0,45 & 0,57 & 0,50 & 0,89 & 0,87 & 0,38 & 0,39 & 0,51 & n.d. & 0,67 & 0,58 & 0,53 \\
\hline $\mathrm{Sm}_{2} \mathrm{O}_{3}$ & n.d. & n.d. & n.d. & n.d. & n.d. & n.d. & n.d. & n.d. & n.d. & n.d. & n.d. & n.d. \\
\hline $\mathrm{Eu}_{2} \mathrm{O}_{3}$ & 0,03 & 0,07 & 0,01 & 0,06 & 0,05 & 0,09 & n.d. & 0,08 & n.d. & 0,11 & 0,01 & 0,07 \\
\hline $\mathrm{Gd}_{2} \mathrm{O}_{3}$ & 0,02 & 0,04 & 0,05 & 0,24 & 0,21 & 0,12 & n.d. & 0,13 & n.d. & 0,18 & 0,16 & 0,13 \\
\hline $\mathrm{F}$ & 0,54 & 0,81 & 0,65 & 0,70 & 0,72 & 0,79 & 0,67 & 0,68 & 1,08 & 0,89 & 0,98 & 0,88 \\
\hline $\mathrm{Cl}$ & 0,04 & 0,02 & 0,03 & 0,09 & 0,05 & 0,08 & 0,02 & 0,04 & 0,01 & 0,03 & 0,05 & 0,08 \\
\hline $\mathrm{H}_{2} \mathrm{O}$ & 13,82 & 13,48 & 13,24 & 13,77 & 13,25 & 12,84 & 13,40 & 13,01 & 12,59 & 12,60 & 13,21 & 13,12 \\
\hline TOTAL & 99,01 & 96,89 & 95,02 & 99,85 & 96,84 & 95,46 & 99,49 & 97,43 & 98,04 & 95,18 & 99,58 & 98,83 \\
\hline $\mathrm{ETR}_{2} \mathrm{O}_{3}$ & 2,35 & 2,79 & 2,45 & 4,18 & 4,43 & 2,71 & 2,15 & 2,68 & 1,12 & 3,35 & 3,02 & 3,13 \\
\hline $\mathrm{O}=\mathrm{F}, \mathrm{Cl}$ & 0,24 & 0,35 & 0,28 & 0,31 & 0,31 & 0,35 & 0,29 & 0,30 & 0,46 & 0,38 & 0,43 & 0,39 \\
\hline Total & 98,77 & 96,54 & 94,74 & 99,54 & 96,52 & 95,11 & 99,21 & 97,13 & 97,59 & 94,80 & 99,15 & 98,45 \\
\hline
\end{tabular}


Análises WDS de Crandalita -continuação.

\begin{tabular}{|c|c|c|c|c|c|c|c|c|c|c|c|c|}
\hline Rocha & Beb. & Beb. & Beb. & Beb. & Beb. & Beb. & Beb. & Beb. & Beb. & Beb. & Beb. & Beb \\
\hline Intemp & Alot. Base & Alot. Base & Alot. Base & Alot. Base & Alot. Base & Alot. Base & Alot. Base & Alot. Base & Alot. Base & Alot. Base & Alot. Base & Alot. Base \\
\hline Prof. (m) & 88,80 & 88,80 & 88,80 & 88,80 & 88,80 & 80,25 & 80,25 & 80,25 & 80,25 & 80,25 & 80,25 & 80,25 \\
\hline Análise & 1 & 2 & 3 & 4 & 5 & 6 & 7 & 8 & 9 & 10 & 11 & 12 \\
\hline $\mathrm{Si}$ & 0,060 & 0,001 & 0,327 & 0,119 & 0,160 & 1,010 & 0,873 & 0,758 & 0,026 & 0,429 & 0,547 & 0,321 \\
\hline $\mathrm{Ti}$ & 0,346 & 0,093 & & 0,147 & - & 0,269 & 0,204 & 0,242 & 0,039 & 0,189 & 0,149 & 0,152 \\
\hline $\mathrm{Zr}$ & 0,002 & 0,012 & 0,005 & - & 0,001 & 0,002 & 0,017 & 0,018 & & 0,007 & 0,022 & 0,004 \\
\hline Th & 0,001 & - & 0,002 & - & - & - & - & 0,001 & 0,002 & - & 0,002 & 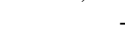 \\
\hline $\mathrm{Al}$ & 5,818 & 5,794 & 5,677 & 5,552 & 5,713 & 5,480 & 5,527 & 5,496 & 6,054 & 5,575 & 5,647 & 5,478 \\
\hline $\mathrm{V}$ & & - & - & & - & & - & & & & & \\
\hline $\mathrm{Cr}$ & - & - & - & 0,004 & - & 0,005 & - & 0,001 & 0,001 & 0,004 & 0,001 & 0,003 \\
\hline $\mathrm{Fe} 3$ & 0,243 & 0,230 & 0,390 & 0,310 & 0,381 & 1,532 & 1,423 & 1,739 & 0,787 & 1,509 & 1,303 & 1,419 \\
\hline $\mathrm{Mn}$ & & - & & - & 0,004 & 0,015 & 0,015 & 0,006 & 0,019 & 0,028 & & 0,019 \\
\hline $\mathrm{Mg}$ & 0,003 & - & 0,001 & - & 0,003 & 0,007 & - & 0,008 & 0,006 & - & 0,001 & 0,008 \\
\hline $\mathrm{Ca}$ & 0,824 & 0,893 & 0,745 & 0,640 & 0,738 & 0,362 & 0,424 & 0,362 & 0,496 & 0,408 & 0,428 & 0,408 \\
\hline $\mathrm{Ba}$ & 0,173 & 0,157 & 0,173 & 0,206 & 0,205 & 0,172 & 0,269 & 0,204 & 0,773 & 0,180 & 0,187 & 0,208 \\
\hline $\mathrm{Sr}$ & 0,502 & 0,481 & 0,528 & 0,485 & 0,487 & 0,309 & 0,315 & 0,313 & 0,292 & 0,420 & 0,486 & 0,440 \\
\hline $\mathrm{Pb}$ & 0,002 & 0,001 & 0,001 & - & - & - & - & 0,002 & - & - & 0,001 & 0,004 \\
\hline $\mathrm{Na}$ & - & - & 0,004 & 0,002 & 0,014 & 0,011 & 0,007 & 0,017 & 0,024 & 0,021 & 0,004 & 0,010 \\
\hline $\mathrm{K}$ & 0,001 & 0,009 & 0,005 & 0,002 & 0,010 & 0,008 & 0,008 & 0,001 & 0,004 & 0,005 & 0,009 & 0,012 \\
\hline $\mathrm{P}$ & 3,700 & 3,913 & 3,764 & 3,920 & 3,814 & 2,626 & 2,795 & 2,710 & 3,452 & 3,011 & 3,003 & 3,232 \\
\hline $\mathrm{Nb}$ & 0,005 & 0,002 & - & 0,005 & - & 0,011 & 0,010 & 0,009 & - & 0,007 & 0,009 & 0,011 \\
\hline $\mathrm{Ta}$ & & & - & & - & & - & - & - & - & & \\
\hline $\mathrm{La}$ & 0,045 & 0,067 & 0,048 & 0,056 & 0,061 & 0,054 & 0,048 & 0,044 & 0,021 & 0,061 & 0,054 & 0,056 \\
\hline $\mathrm{Ce}$ & 0,044 & 0,036 & 0,053 & 0,098 & 0,113 & 0,060 & 0,042 & 0,060 & 0,040 & 0,072 & 0,065 & 0,072 \\
\hline $\operatorname{Pr}$ & 0,012 & 0,015 & 0,006 & 0,010 & 0,012 & 0,009 & 0,009 & 0,010 & 0,002 & 0,009 & 0,008 & 0,009 \\
\hline $\mathrm{Nd}$ & 0,024 & 0,031 & 0,028 & 0,047 & 0,048 & 0,022 & 0,021 & 0,029 & - & 0,039 & 0,032 & 0,029 \\
\hline Sm & - & - & - & - & - & - & - & - & - & - & - & 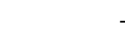 \\
\hline $\mathrm{Eu}$ & 0,001 & 0,004 & - & 0,003 & 0,003 & 0,005 & - & 0,004 & - & 0,006 & 0,001 & 0,003 \\
\hline $\mathrm{Gd}$ & 0,001 & 0,002 & 0,003 & 0,012 & 0,011 & 0,006 & - & 0,007 & - & 0,009 & 0,008 & 0,007 \\
\hline Cations & 11,807 & 11,740 & 11,759 & 11,621 & 11,778 & 11,976 & 12,006 & 12,041 & 12,041 & 11,989 & 11,965 & 11,906 \\
\hline $\bar{F}$ & 0,256 & 0,388 & 0,318 & 0,327 & 0,349 & 0,398 & 0,325 & 0,338 & 0,546 & 0,454 & 0,476 & 0,428 \\
\hline $\mathrm{Cl}$ & 0,011 & 0,005 & 0,007 & 0,023 & 0,013 & 0,020 & 0,005 & 0,011 & 0,001 & 0,007 & 0,014 & 0,020 \\
\hline $\mathrm{OH}$ & 13,733 & 13,608 & 13,675 & 13,650 & 13,638 & 13,582 & 13,669 & 13,650 & 13,452 & 13,539 & 13,510 & 13,552 \\
\hline $\mathrm{H}_{2} \mathrm{O}$ & 13,821 & 13,484 & 13,235 & 13,772 & 13,253 & 12,839 & 13,398 & 13,006 & 12,593 & 12,597 & 13,214 & 13,121 \\
\hline
\end{tabular}


Análises WDS de Perovskita.

\begin{tabular}{|c|c|c|c|c|c|c|c|c|c|c|c|c|}
\hline Rocha & Beb. & Beb. & Beb. & Beb. & Beb. & Beb. & Beb. & Beb. & Beb. & Beb. & Beb. & Beb. \\
\hline Intemp. & $\begin{array}{r}\text { Isalt. Mic. } \\
\text { Topo }\end{array}$ & $\begin{array}{r}\text { Isalt. Mic. } \\
\text { Topo }\end{array}$ & $\begin{array}{r}\text { Isalt. Mic. } \\
\text { Topo }\end{array}$ & $\begin{array}{r}\text { Isalt. Mic. } \\
\text { Topo }\end{array}$ & $\begin{array}{r}\text { Isalt. Mic. } \\
\text { Topo }\end{array}$ & $\begin{array}{r}\text { Isalt. Mic. } \\
\text { Topo }\end{array}$ & $\begin{array}{r}\text { Isalt. Mic. } \\
\text { Topo }\end{array}$ & $\begin{array}{r}\text { Isalt. Mic. } \\
\text { Topo }\end{array}$ & $\begin{array}{r}\text { Isalt. Mic. } \\
\text { Topo }\end{array}$ & $\begin{array}{r}\text { Isalt. Mic. } \\
\text { Topo }\end{array}$ & $\begin{array}{r}\text { Isalt. Mic. } \\
\text { Topo }\end{array}$ & $\begin{array}{r}\text { Isalt. Mic. } \\
\text { Topo }\end{array}$ \\
\hline Prof. (m) & 130 & 130 & 130 & 130 & 130 & 130 & 130 & 130 & 130 & 130 & 130 & 130 \\
\hline Análise & 1 & 2 & 3 & 4 & 5 & 6 & 7 & 8 & 9 & 10 & 11 & 12 \\
\hline $\mathrm{SiO}_{2}$ & n.d. & n.d. & n.d. & n.d. & 0,01 & n.d. & 0,02 & 0,01 & n.d. & 0,02 & n.d. & n.d. \\
\hline $\mathrm{TiO}_{2}$ & 57,08 & 56,76 & 56,71 & 56,95 & 57,22 & 57,09 & 56,84 & 57,29 & 56,91 & 57,05 & 55,94 & 55,96 \\
\hline $\mathrm{Al}_{2} \mathrm{O}_{3}$ & 0,06 & 0,04 & 0,04 & 0,06 & 0,09 & 0,04 & 0,08 & 0,07 & 0,09 & 0,09 & 0,03 & 0,10 \\
\hline $\mathrm{FeO}$ & 1,22 & 1,46 & 1,09 & 1,27 & 1,14 & 1,14 & 1,24 & 1,23 & 1,23 & 1,29 & 1,45 & 1,49 \\
\hline $\mathrm{MnO}$ & n.d. & n.d. & 0,03 & 0,10 & 0,11 & 0,01 & n.d. & n.d. & 0,07 & n.d. & 0,02 & 0,05 \\
\hline $\mathrm{MgO}$ & 0,04 & n.d. & n.d. & 0,02 & n.d. & 0,01 & 0,02 & 0,05 & n.d. & 0,02 & n.d. & 0,04 \\
\hline $\mathrm{CaO}$ & 39,07 & 38,19 & 38,61 & 38,86 & 39,25 & 38,65 & 38,45 & 38,33 & 38,83 & 38,51 & 38,56 & 37,90 \\
\hline $\mathrm{Na}_{2} \mathrm{O}$ & 0,24 & 0,28 & 0,27 & 0,22 & 0,21 & 0,24 & 0,33 & 0,27 & 0,33 & 0,38 & 0,40 & 0,40 \\
\hline $\mathrm{ThO}_{2}$ & n.d. & n.d. & 0,02 & 0,02 & 0,05 & 0,02 & 0,05 & 0,13 & 0,08 & 0,05 & n.d. & 0,08 \\
\hline $\mathrm{ZrO}_{2}$ & n.d. & 0,10 & 0,20 & 0,15 & n.d. & n.d. & 0,16 & 0,04 & n.d. & n.d. & 0,17 & 0,13 \\
\hline $\mathrm{SrO}$ & 0,17 & 0,18 & 0,37 & 0,09 & 0,30 & 0,35 & 0,27 & 0,16 & 0,17 & 0,10 & 0,33 & 0,42 \\
\hline $\mathrm{Nb}_{2} \mathrm{O}_{5}$ & 0,47 & 0,25 & 0,37 & 0,46 & 0,22 & 0,39 & 0,45 & 0,45 & 0,37 & 0,39 & 0,82 & 0,76 \\
\hline $\mathrm{Ta}_{2} \mathrm{O}_{5}$ & n.d. & n.d. & n.d. & n.d. & n.d. & n.d. & n.d. & n.d. & n.d. & n.d. & n.d. & n.d. \\
\hline $\mathrm{La}_{2} \mathrm{O}_{3}$ & 0,57 & 0,58 & 0,58 & 0,50 & 0,49 & 0,48 & 0,58 & 0,56 & 0,47 & 0,59 & 0,79 & 0,73 \\
\hline $\mathrm{Ce}_{2} \mathrm{O}_{3}$ & 0,84 & 0,90 & 1,08 & 0,98 & 1,11 & 1,02 & 0,98 & 0,84 & 0,87 & 0,82 & 1,36 & 1,32 \\
\hline $\mathrm{Pr}_{2} \mathrm{O}_{3}$ & 0,11 & 0,10 & 0,17 & 0,08 & 0,05 & 0,07 & 0,08 & 0,07 & 0,07 & 0,10 & 0,11 & 0,12 \\
\hline $\mathrm{Nd}_{2} \mathrm{O}_{3}$ & 0,45 & 0,57 & 0,61 & 0,46 & 0,58 & 0,72 & 0,45 & 0,39 & 0,46 & 0,44 & 0,59 & 0,63 \\
\hline $\mathrm{Y}_{2} \mathrm{O}_{3}$ & n.d. & n.d. & n.d. & n.d. & n.d. & n.d. & n.d. & n.d. & n.d. & n.d. & n.d. & n.d. \\
\hline Total & 100,31 & 99,40 & 100,13 & 100,20 & 100,81 & 100,21 & 99,99 & 99,85 & 99,95 & 99,83 & 100,58 & 100,11 \\
\hline
\end{tabular}


Análises WDS de Perovskita - continuação.

\begin{tabular}{|c|c|c|c|c|c|c|c|c|c|c|c|c|}
\hline Rocha & Beb. & Beb. & Beb. & Beb. & Beb. & Beb. & Beb. & Beb. & Beb. & Beb. & Beb. & Beb. \\
\hline Intemp. & $\begin{array}{r}\text { Isalt. Mic. } \\
\text { Topo }\end{array}$ & $\begin{array}{r}\text { Isalt. Mic. } \\
\text { Topo }\end{array}$ & $\begin{array}{r}\text { Isalt. Mic. } \\
\text { Topo }\end{array}$ & $\begin{array}{r}\text { Isalt. Mic. } \\
\text { Topo }\end{array}$ & $\begin{array}{r}\text { Isalt. Mic. } \\
\text { Topo }\end{array}$ & $\begin{array}{r}\text { Isalt. Mic. } \\
\text { Topo }\end{array}$ & $\begin{array}{r}\text { Isalt. Mic. } \\
\text { Topo }\end{array}$ & $\begin{array}{r}\text { Isalt. Mic. } \\
\text { Topo }\end{array}$ & $\begin{array}{r}\text { Isalt. Mic. } \\
\text { Topo }\end{array}$ & $\begin{array}{r}\text { Isalt. Mic. } \\
\text { Topo }\end{array}$ & $\begin{array}{r}\text { Isalt. Mic. } \\
\text { Topo }\end{array}$ & $\begin{array}{r}\text { Isalt. Mic. } \\
\text { Topo }\end{array}$ \\
\hline Prof. (m) & 130 & 130 & 130 & 130 & 130 & 130 & 130 & 130 & 130 & 130 & 130 & 130 \\
\hline Análise & 1 & 2 & 3 & 4 & 5 & 6 & 7 & 8 & 9 & 10 & 11 & 12 \\
\hline $\mathrm{Si}$ & - & - & - & - & - & - & - & - & - & - & - & - \\
\hline $\mathrm{Al}$ & 0,976 & 0,978 & 0,977 & 0,975 & 0,976 & 0,979 & 0,977 & 0,981 & 0,976 & 0,978 & 0,960 & 0,967 \\
\hline $\mathrm{Ti}$ & 0,002 & 0,001 & 0,001 & 0,002 & 0,002 & 0,001 & 0,002 & 0,002 & 0,002 & 0,002 & 0,001 & 0,003 \\
\hline $\mathrm{Fe}^{3}$ & 0,021 & 0,025 & 0,019 & 0,022 & 0,020 & 0,019 & 0,021 & 0,021 & 0,021 & 0,022 & 0,025 & 0,026 \\
\hline Mn & - & - & - & 0,002 & 0,002 & - & - & - & 0,001 & - & - & 0,001 \\
\hline $\mathrm{Mg}$ & 0,001 & - & - & 0,001 & - & - & 0,001 & 0,002 & - & 0,001 & - & 0,001 \\
\hline $\mathrm{Ca}$ & 0,952 & 0,937 & 0,947 & 0,947 & 0,954 & 0,944 & 0,942 & 0,935 & 0,948 & 0,941 & 0,942 & 0,933 \\
\hline $\mathrm{Na}$ & 0,010 & 0,012 & 0,012 & 0,009 & 0,009 & 0,011 & 0,015 & 0,012 & 0,015 & 0,017 & 0,018 & 0,018 \\
\hline Th & - & - & - & - & - & - & - & 0,001 & - & - & - & - \\
\hline $\mathrm{Zr}$ & - & 0,001 & 0,002 & 0,002 & - & - & 0,002 & - & - & - & 0,002 & 0,001 \\
\hline $\mathrm{Sr}$ & 0,002 & 0,002 & 0,005 & 0,001 & 0,004 & 0,005 & 0,004 & 0,002 & 0,002 & 0,001 & 0,004 & 0,006 \\
\hline $\mathrm{Nb}$ & 0,005 & 0,003 & 0,004 & 0,005 & 0,002 & 0,004 & 0,005 & 0,005 & 0,004 & 0,004 & 0,008 & 0,008 \\
\hline $\mathrm{Ta}$ & - & - & - & - & - & - & - & - & - & - & - & - \\
\hline $\mathrm{La}$ & 0,005 & 0,005 & 0,005 & 0,004 & 0,004 & 0,004 & 0,005 & 0,005 & 0,004 & 0,005 & 0,007 & 0,006 \\
\hline $\mathrm{Ce}$ & 0,007 & 0,008 & 0,009 & 0,008 & 0,009 & 0,008 & 0,008 & 0,007 & 0,007 & 0,007 & 0,011 & 0,011 \\
\hline $\operatorname{Pr}$ & 0,001 & 0,001 & 0,001 & 0,001 & - & 0,001 & 0,001 & 0,001 & 0,001 & 0,001 & 0,001 & 0,001 \\
\hline $\mathrm{Nd}$ & 0,004 & 0,005 & 0,005 & 0,004 & 0,005 & 0,006 & 0,004 & 0,003 & 0,004 & 0,004 & 0,005 & 0,005 \\
\hline Y & - & - & - & - & - & - & - & - & - & - & - & - \\
\hline Cátions & 1,985 & 1,978 & 1,987 & 1,982 & 1,988 & 1,983 & 1,986 & 1,975 & 1,985 & 1,983 & 1,984 & 1,988 \\
\hline
\end{tabular}


Análises WDS de Anatásio (I).

\begin{tabular}{|c|c|c|c|c|c|c|c|c|c|c|c|c|c|c|c|c|}
\hline Rocha & Beb. & Beb. & Beb. & Beb. & Beb. & Beb. & Beb. & Beb. & Beb. & Beb. & Beb. & Beb. & Beb. & Beb. & Beb. & Beb. \\
\hline Intemp & $\begin{array}{l}\text { Isalt. Mic. } \\
\text { Topo. }\end{array}$ & Alot Base & Alot. Base & Alot Base & Alot Base & Alot Base & Alot Base & Alot Base & Alot Base & Alot Base & Alot Base & Alot Base & Alot Base & Alot Base & Alot Base & Alot Base \\
\hline Prof. (m) & 130,0 & 117,0 & 117,0 & 117,0 & 117,0 & 117,0 & 117,0 & 117,0 & 117,0 & 117,0 & 117,0 & 117,0 & 117,0 & 117,0 & 117,0 & 117,0 \\
\hline Análise & 50 & 61 & 63 & 64 & 89 & 91 & 100 & 108 & 66 & 67 & 69 & 77 & 79 & 80 & 85 & 86 \\
\hline $\mathrm{SiO}_{2}$ & 0,98 & 0,02 & 0,05 & 0,09 & 0,05 & 0,02 & 0,03 & 0,07 & 0,02 & 0,04 & 0,04 & 0,04 & 0,07 & 0,02 & 0,05 & 0,08 \\
\hline $\mathrm{TiO}_{2}$ & 94,98 & 82,11 & 83,82 & 80,97 & 86,05 & 78,53 & 83,75 & 81,54 & 88,70 & 75,61 & 86,11 & 83,88 & 82,25 & 88,42 & 79,67 & 89,72 \\
\hline $\mathrm{ZrO}_{2}$ & 0,05 & 0,34 & 0,19 & 0,27 & n.d. & 0,22 & 0,36 & 0,04 & 0,17 & 0,23 & 0,08 & 0,11 & 0,24 & 0,31 & 0,21 & 0,39 \\
\hline $\mathrm{ThO}_{2}$ & n.d. & 0,06 & 0,08 & 0,11 & 0,02 & 0,11 & 0,06 & 0,02 & n.d. & 0,05 & 0,05 & 0,06 & 0,09 & 0,06 & 0,09 & 0,14 \\
\hline $\mathrm{Al}_{2} \mathrm{O}_{3}$ & 0,03 & 1,47 & 2,04 & 1,71 & 1,85 & 1,22 & 1,60 & 1,90 & 1,47 & 1,75 & 1,61 & 1,81 & 1,71 & 1,79 & 1,72 & 1,86 \\
\hline $\mathrm{V}_{2} \mathrm{O}_{3}$ & 0,85 & 0,83 & 0,83 & 0,76 & 0,70 & 0,82 & 0,71 & 0,59 & 0,88 & 0,62 & 0,85 & 0,85 & 0,76 & 0,80 & 0,83 & 1,14 \\
\hline $\mathrm{Cr}_{2} \mathrm{O}_{3}$ & n.d. & n.d. & n.d. & n.d. & n.d. & 0,04 & 0,03 & 0,07 & n.d. & n.d. & n.d. & 0,04 & 0,02 & n.d. & n.d. & 0,02 \\
\hline $\mathrm{Fe}_{2} \mathrm{O}_{3}$ & 0,87 & 4,43 & 3,21 & 5,07 & 3,05 & 2,06 & 3,21 & 3,25 & 3,90 & 1,94 & 2,56 & 2,22 & 2,37 & 2,18 & 3,71 & 3,01 \\
\hline $\mathrm{MnO}$ & 0,02 & 1,41 & 0,47 & 0,92 & 0,73 & 0,52 & 1,24 & 1,58 & 0,58 & 1,30 & 0,96 & 2,03 & 1,94 & 0,66 & 0,79 & 0,41 \\
\hline $\mathrm{MgO}$ & 0,10 & n.d. & n.d. & n.d. & 0,02 & n.d. & n.d. & 0,04 & n.d. & n.d. & n.d. & n.d. & n.d. & n.d. & 0,01 & n.d. \\
\hline $\mathrm{CaO}$ & 0,32 & 0,17 & 0,05 & 0,13 & 0,07 & 0,90 & 0,16 & 0,19 & 0,05 & 0,90 & 0,16 & 0,09 & 0,28 & 0,04 & 0,23 & 0,05 \\
\hline $\mathrm{BaO}$ & 0,51 & 0,25 & 0,48 & 0,21 & 0,27 & 0,01 & 0,22 & 0,36 & 0,51 & 0,11 & 0,12 & 0,17 & 0,35 & 0,30 & 0,22 & 0,38 \\
\hline $\mathrm{SrO}$ & 0,13 & 0,23 & 0,10 & 0,10 & 0,02 & 0,10 & 0,01 & 0,16 & 0,02 & n.d. & n.d. & n.d. & 0,03 & 0,02 & 0,12 & 0,06 \\
\hline $\mathrm{Na}_{2} \mathrm{O}$ & 0,01 & 0,05 & 0,05 & 0,05 & 0,04 & n.d. & 0,01 & 0,06 & 0,03 & 0,01 & 0,02 & n.d. & 0,04 & 0,06 & 0,14 & 0,10 \\
\hline $\mathrm{K}_{2} \mathrm{O}$ & 0,04 & 0,06 & 0,04 & 0,01 & n.d. & 0,03 & 0,03 & n.d. & 0,03 & 0,03 & 0,03 & 0,02 & 0,04 & n.d. & 0,01 & 0,02 \\
\hline $\mathrm{P}_{2} \mathrm{O}_{5}$ & 0,08 & 2,72 & 2,39 & 3,01 & 2,31 & 5,68 & 2,23 & 2,29 & 1,89 & 6,50 & 1,84 & 2,42 & 3,05 & 2,09 & 3,41 & 1,74 \\
\hline $\mathrm{Nb}_{2} \mathrm{O}_{5}$ & 1,18 & 1,21 & 1,25 & 1,08 & 1,05 & 1,09 & 1,22 & 1,26 & 1,21 & 0,76 & 1,17 & 0,66 & 0,51 & 1,35 & 1,22 & 1,18 \\
\hline $\mathrm{La}_{2} \mathrm{O}_{3}$ & n.d. & 1,27 & n.d. & 0,11 & 0,01 & 1,89 & 0,06 & 0,74 & n.d. & 1,49 & 1,35 & 0,30 & 0,33 & n.d. & 0,72 & 0,01 \\
\hline $\mathrm{Ce}_{2} \mathrm{O}_{3}$ & n.d. & 2,29 & n.d. & 0,14 & n.d. & 1,80 & n.d. & 2,41 & n.d. & 3,23 & 1,84 & 0,64 & 0,79 & n.d. & 1,31 & n.d. \\
\hline $\mathrm{Pr}_{2} \mathrm{O}_{3}$ & 0,05 & 0,32 & n.d. & n.d. & n.d. & 0,38 & n.d. & 0,11 & 0,02 & 0,28 & 0,24 & 0,03 & 0,04 & 0,07 & 0,15 & 0,03 \\
\hline $\mathrm{Nd}_{2} \mathrm{O}_{3}$ & n.d. & 1,58 & n.d. & 0,37 & 0,08 & 1,80 & 0,17 & 0,82 & n.d. & 1,51 & 1,07 & 0,30 & 0,32 & n.d. & 0,89 & n.d. \\
\hline $\mathrm{Y}_{2} \mathrm{O}_{3}$ & n.d. & n.d. & n.d. & n.d. & n.d. & n.d. & n.d. & n.d. & n.d. & n.d. & n.d. & n.d. & n.d. & n.d. & n.d. & n.d. \\
\hline TOTAL & 100,21 & 100,82 & 95,04 & 95,12 & 96,33 & 97,24 & 95,10 & 97,49 & 99,49 & 96,34 & 100,11 & 95,66 & 95,23 & 98,16 & 95,49 & 100,32 \\
\hline
\end{tabular}


Análises WDS de Anatásio (I) - continuação.

\begin{tabular}{|c|c|c|c|c|c|c|c|c|c|c|c|c|c|c|c|c|}
\hline Rocha & Beb. & Beb. & Beb. & Beb. & Beb. & Beb. & Beb. & Beb. & Beb. & Beb. & Beb. & Beb. & Beb. & Beb. & Beb. & Beb. \\
\hline Intemp & $\begin{array}{r}\text { Isalt. Mic. } \\
\text { Topo. }\end{array}$ & Alot Base & Alot. Base & Alot Base & Alot Base & Alot Base & Alot Base & Alot Base & Alot Base & Alot Base & Alot Base & Alot Base & Alot Base & Alot Base & Alot Base & Alot Base \\
\hline Prof. (m) & 130,0 & 117,0 & 117,0 & 117,0 & 117,0 & 117,0 & 117,0 & 117,0 & 117,0 & 117,0 & 117,0 & 117,0 & 117,0 & 117,0 & 117,0 & 117,0 \\
\hline Análise & 50 & 61 & 63 & 64 & 89 & 91 & 100 & 108 & 66 & 67 & 69 & 77 & 79 & 80 & 85 & 86 \\
\hline $\mathrm{Si}$ & 0,013 & - & 0,001 & 0,001 & 0,001 & - & - & 0,001 & - & 0,001 & - & 0,001 & 0,001 & - & 0,001 & 0,001 \\
\hline $\mathrm{Ti}$ & 0,957 & 0,855 & 0,888 & 0,863 & 0,898 & 0,830 & 0,890 & 0,868 & 0,902 & 0,809 & 0,890 & 0,890 & 0,878 & 0,906 & 0,856 & 0,903 \\
\hline $\mathrm{Zr}$ & - & 0,002 & 0,001 & 0,002 & - & 0,002 & 0,002 & - & 0,001 & 0,002 & 0,001 & 0,001 & 0,002 & 0,002 & 0,001 & 0,003 \\
\hline Th & - & - & - & - & - & - & - & - & - & - & - & - & - & - & - & - \\
\hline $\mathrm{Al}$ & - & 0,024 & 0,034 & 0,029 & 0,030 & 0,020 & 0,027 & 0,032 & 0,023 & 0,029 & 0,026 & 0,030 & 0,029 & 0,029 & 0,029 & 0,029 \\
\hline V & 0,009 & 0,009 & 0,009 & 0,009 & 0,008 & 0,009 & 0,008 & 0,007 & 0,010 & 0,007 & 0,009 & 0,010 & 0,009 & 0,009 & 0,010 & 0,012 \\
\hline $\mathrm{Cr}$ & - & - & - & - & - & - & - & 0,001 & - & - & - & - & - & - & - & - \\
\hline $\mathrm{Fe}^{3}$ & 0,009 & 0,046 & 0,034 & 0,054 & 0,032 & 0,022 & 0,034 & 0,035 & 0,040 & 0,021 & 0,026 & 0,024 & 0,025 & 0,022 & 0,040 & 0,030 \\
\hline Mn & - & 0,016 & 0,006 & 0,011 & 0,009 & 0,006 & 0,015 & 0,019 & 0,007 & 0,016 & 0,011 & 0,024 & 0,023 & 0,008 & 0,010 & 0,005 \\
\hline Mg & 0,002 & - & - & - & - & - & - & 0,001 & - & - & - & - & - & - & - & - \\
\hline $\mathrm{Ca}$ & 0,005 & 0,002 & 0,001 & 0,002 & 0,001 & 0,014 & 0,002 & 0,003 & 0,001 & 0,014 & 0,002 & 0,001 & 0,004 & 0,001 & 0,004 & 0,001 \\
\hline $\mathrm{Ba}$ & 0,003 & 0,001 & 0,003 & 0,001 & 0,001 & - & 0,001 & 0,002 & 0,003 & 0,001 & 0,001 & 0,001 & 0,002 & 0,002 & 0,001 & 0,002 \\
\hline $\mathrm{Sr}$ & 0,001 & 0,002 & 0,001 & 0,001 & - & 0,001 & - & 0,001 & - & - & - & - & - & - & 0,001 & - \\
\hline $\mathrm{Na}$ & - & 0,001 & 0,001 & 0,001 & 0,001 & - & - & 0,002 & 0,001 & - & 0,001 & - & 0,001 & 0,002 & 0,004 & 0,003 \\
\hline K & 0,001 & 0,001 & 0,001 & - & - & 0,001 & - & - & - & - & 0,001 & - & 0,001 & - & - & - \\
\hline $\mathrm{P}$ & 0,001 & 0,032 & 0,028 & 0,036 & 0,027 & 0,068 & 0,027 & 0,027 & 0,022 & 0,078 & 0,021 & 0,029 & 0,037 & 0,024 & 0,041 & 0,020 \\
\hline $\mathrm{Nb}$ & 0,007 & 0,008 & 0,008 & 0,007 & 0,007 & 0,007 & 0,008 & 0,008 & 0,007 & 0,005 & 0,007 & 0,004 & 0,003 & 0,008 & 0,008 & 0,007 \\
\hline $\mathrm{La}$ & - & 0,006 & - & 0,001 & - & 0,010 & - & 0,004 & - & 0,008 & 0,007 & 0,002 & 0,002 & - & 0,004 & - \\
\hline $\mathrm{Ce}$ & - & 0,012 & - & 0,001 & - & 0,009 & - & 0,012 & - & 0,017 & 0,009 & 0,003 & 0,004 & - & 0,007 & - \\
\hline $\operatorname{Pr}$ & - & 0,002 & - & - & - & 0,002 & - & 0,001 & - & 0,001 & 0,001 & - & - & - & 0,001 & - \\
\hline $\mathrm{Nd}$ & - & 0,008 & - & 0,002 & - & 0,009 & 0,001 & 0,004 & - & 0,008 & 0,005 & 0,002 & 0,002 & - & 0,005 & - \\
\hline Y & - & - & - & - & - & - & - & - & - & - & - & - & - & - & - & - \\
\hline Cations & 1,009 & 1,030 & 1,016 & 1,021 & 1,016 & 1,013 & 1,018 & 1,029 & 1,017 & 1,018 & 1,022 & 1,023 & 1,024 & 1,013 & 1,022 & 1,017 \\
\hline
\end{tabular}


Análises WDS de Anatásio (II).

\begin{tabular}{|c|c|c|c|c|c|c|c|c|c|c|c|c|c|c|c|c|}
\hline Rocha & Beb. & Beb. & Beb. & Beb. & Beb. & Beb. & Beb. & Beb. & Beb. & Beb. & Beb. & Beb. & Beb. & Beb. & Beb. & Beb. \\
\hline Intemp. & Alot Base & Alot Base & Alot. Base & Alot Base & Alot Base & Alot Base & Alot Base & Alot Base & Alot Base & Alot Base & Alot Base & Alot Base & Alot Base & Alot Base & Alot Base & Alot Base \\
\hline Prof. (m) & 117,0 & 88,8 & 88,8 & 88,8 & 88,8 & 88,8 & 88,8 & 88,8 & 88,8 & 88,8 & 88,8 & 88,8 & 88,8 & 88,8 & 88,8 & 88,8 \\
\hline Análise & 88 & 4 & 34 & 35 & 36 & 37 & 39 & 40 & 41 & 42 & 13 & 18 & 19 & 21 & 22 & 23 \\
\hline $\mathrm{SiO}_{2}$ & 0,07 & 0,18 & 0,22 & 0,48 & 0,21 & 0,16 & 0,61 & 0,14 & 0,14 & 0,09 & 0,17 & 0,38 & 0,41 & 0,08 & 0,15 & 0,09 \\
\hline $\mathrm{TiO}_{2}$ & 87,09 & 86,22 & 88,02 & 87,13 & 83,09 & 83,87 & 84,99 & 83,91 & 86,08 & 86,67 & 79,75 & 87,80 & 89,08 & 81,16 & 83,30 & 76,57 \\
\hline $\mathrm{ZrO}_{2}$ & 0,15 & 0,02 & 0,26 & 0,24 & 0,28 & 0,44 & n.d. & 0,09 & 0,39 & 0,15 & 0,25 & 0,07 & 0,19 & 0,34 & 0,26 & 0,11 \\
\hline $\mathrm{ThO}_{2}$ & 0,09 & 0,07 & n.d. & 0,01 & 0,08 & 0,01 & 0,12 & 0,04 & 0,03 & n.d. & n.d. & 0,03 & n.d. & 0,12 & 0,01 & 0,09 \\
\hline $\mathrm{Al}_{2} \mathrm{O}_{3}$ & 1,59 & 3,39 & 2,19 & 3,53 & 3,50 & 4,79 & 3,53 & 4,17 & 3,64 & 3,30 & 3,17 & 1,85 & 1,90 & 4,63 & 4,88 & 7,63 \\
\hline $\mathrm{V}_{2} \mathrm{O}_{3}$ & 0,89 & 0,76 & 0,89 & 0,76 & 0,78 & 0,84 & 0,74 & 0,74 & 0,91 & 0,63 & 0,73 & 0,89 & 0,86 & 0,68 & 0,72 & 0,70 \\
\hline $\mathrm{Cr}_{2} \mathrm{O}_{3}$ & n.d. & n.d. & 0,02 & n.d. & 0,07 & 0,10 & n.d. & n.d. & n.d. & n.d. & 0,05 & 0,05 & 0,04 & n.d. & 0,05 & 0,05 \\
\hline $\mathrm{Fe}_{2} \mathrm{O}_{3}$ & 3,90 & 4,38 & 2,88 & 3,66 & 4,86 & 2,56 & 4,01 & 4,64 & 3,48 & 3,31 & 6,68 & 2,83 & 2,50 & 4,07 & 2,63 & 3,06 \\
\hline $\mathrm{MnO}$ & 0,48 & 0,17 & 0,17 & 0,07 & 0,10 & 0,37 & 0,10 & 0,26 & 0,34 & 0,17 & 0,47 & 0,48 & 0,67 & 0,03 & 0,09 & 0,08 \\
\hline $\mathrm{MgO}$ & n.d. & 0,02 & n.d. & 0,04 & 0,03 & n.d. & 0,03 & 0,01 & n.d. & n.d. & n.d. & 0,02 & 0,03 & 0,02 & 0,03 & n.d. \\
\hline $\mathrm{CaO}$ & 0,14 & 0,12 & 0,07 & 0,08 & 0,04 & 0,06 & 0,19 & 0,09 & 0,07 & 0,13 & 0,13 & 0,11 & 0,08 & 0,06 & 0,44 & 0,65 \\
\hline $\mathrm{BaO}$ & 0,62 & 0,37 & 0,30 & 0,26 & 0,34 & 0,20 & 0,22 & 0,29 & 0,21 & 0,38 & 0,57 & 0,38 & 0,32 & 0,39 & 0,36 & 0,44 \\
\hline $\mathrm{SrO}$ & n.d. & n.d. & 0,07 & 0,04 & n.d. & 0,13 & n.d. & n.d. & n.d. & n.d. & 0,09 & n.d. & n.d. & n.d. & 0,02 & 0,26 \\
\hline $\mathrm{Na}_{2} \mathrm{O}$ & 0,01 & 0,11 & n.d. & 0,10 & 0,06 & 0,17 & 0,05 & 0,14 & 0,04 & 0,10 & 0,12 & 0,09 & 0,07 & 0,08 & 0,03 & 0,01 \\
\hline $\mathrm{K}_{2} \mathrm{O}$ & 0,02 & n.d. & n.d. & 0,02 & n.d. & n.d. & 0,02 & 0,04 & 0,01 & 0,01 & 0,01 & 0,01 & 0,02 & 0,02 & 0,03 & 0,06 \\
\hline $\mathrm{P}_{2} \mathrm{O}_{5}$ & 2,29 & 2,60 & 1,72 & 2,66 & 2,74 & 3,34 & 2,93 & 3,30 & 2,91 & 2,23 & 3,20 & 1,91 & 1,58 & 3,20 & 3,76 & 5,59 \\
\hline $\mathrm{Nb}_{2} \mathrm{O}_{5}$ & 1,07 & 0,54 & 1,16 & 0,79 & 0,90 & 0,98 & 0,56 & 0,47 & 1,16 & 1,27 & 0,81 & 1,21 & 1,43 & 1,31 & 0,75 & 0,95 \\
\hline $\mathrm{La}_{2} \mathrm{O}_{3}$ & 0,22 & 0,11 & 0,01 & n.d. & n.d. & 0,01 & n.d. & n.d. & n.d. & n.d. & n.d. & 0,07 & n.d. & n.d. & 0,43 & 0,12 \\
\hline $\mathrm{Ce}_{2} \mathrm{O}_{3}$ & 0,05 & n.d. & n.d. & n.d. & n.d. & n.d. & n.d. & n.d. & n.d. & n.d. & n.d. & 0,75 & 0,66 & n.d. & 0,96 & 0,04 \\
\hline $\mathrm{Pr}_{2} \mathrm{O}_{3}$ & 0,06 & n.d. & n.d. & n.d. & n.d. & 0,02 & 0,04 & 0,06 & 0,01 & 0,04 & n.d. & 0,01 & n.d. & n.d. & 0,21 & n.d. \\
\hline $\mathrm{Nd}_{2} \mathrm{O}_{3}$ & 0,31 & 0,02 & 0,03 & n.d. & n.d. & n.d. & n.d. & n.d. & n.d. & n.d. & 0,09 & 0,16 & n.d. & n.d. & 0,41 & 0,16 \\
\hline $\mathrm{Y}_{2} \mathrm{O}_{3}$ & n.d. & n.d. & n.d. & n.d. & n.d. & n.d. & n.d. & n.d. & n.d. & n.d. & n.d. & n.d. & n.d. & n.d. & n.d. & n.d. \\
\hline TOTAL & 99,03 & 99,07 & 97,98 & 99,85 & 97,05 & 98,05 & 98,14 & 98,37 & 99,41 & 98,48 & 96,29 & 99,10 & 99,81 & 96,20 & 99,51 & 96,63 \\
\hline
\end{tabular}


Análises WDS de Anatásio (II) - continuação.

\begin{tabular}{|c|c|c|c|c|c|c|c|c|c|c|c|c|c|c|c|c|}
\hline Rocha & Beb. & Beb. & Beb. & Beb. & Beb. & Beb. & Beb. & Beb. & Beb. & Beb. & Beb. & Beb. & Beb. & Beb. & Beb. & Beb. \\
\hline Intemp. & Alot Base & Alot Base & Alot. Base & Alot Base & Alot Base & Alot Base & Alot Base & Alot Base & Alot Base & Alot Base & Alot Base & Alot Base & Alot Base & Alot Base & Alot Base & Alot Base \\
\hline Prof. (m) & 117,0 & 88,8 & 88,8 & 88,8 & 88,8 & 88,8 & 88,8 & 88,8 & 88,8 & 88,8 & 88,8 & 88,8 & 88,8 & 88,8 & 88,8 & 88,8 \\
\hline Análise & 88 & 4 & 34 & 35 & 36 & 37 & 39 & 40 & 41 & 42 & 13 & 18 & 19 & 21 & 22 & 23 \\
\hline $\mathrm{Si}$ & 0,001 & 0,002 & 0,003 & 0,006 & 0,003 & 0,002 & 0,008 & 0,002 & 0,002 & 0,001 & 0,002 & 0,005 & 0,005 & 0,001 & 0,002 & 0,001 \\
\hline $\mathrm{Ti}$ & 0,892 & 0,872 & 0,903 & 0,870 & 0,858 & 0,850 & 0,863 & 0,851 & 0,865 & 0,882 & 0,837 & 0,896 & 0,902 & 0,842 & 0,840 & 0,780 \\
\hline $\mathrm{Zr}$ & 0,001 & - & 0,002 & 0,002 & 0,002 & 0,003 & - & 0,001 & 0,003 & 0,001 & 0,002 & - & 0,001 & 0,002 & 0,002 & 0,001 \\
\hline Th & - & - & - & - & - & - & - & - & - & - & - & - & - & - & - & - \\
\hline $\mathrm{Al}$ & 0,026 & 0,054 & 0,035 & 0,055 & 0,057 & 0,076 & 0,056 & 0,066 & 0,057 & 0,053 & 0,052 & 0,030 & 0,030 & 0,075 & 0,077 & 0,122 \\
\hline V & 0,010 & 0,008 & 0,010 & 0,008 & 0,009 & 0,009 & 0,008 & 0,008 & 0,010 & 0,007 & 0,008 & 0,010 & 0,009 & 0,007 & 0,008 & 0,008 \\
\hline $\mathrm{Cr}$ & - & - & - & - & 0,001 & 0,001 & - & - & - & - & 0,001 & 0,001 & - & - & 0,001 & 0,001 \\
\hline $\mathrm{Fe}^{3}$ & 0,040 & 0,044 & 0,030 & 0,037 & 0,050 & 0,026 & 0,041 & 0,047 & 0,035 & 0,034 & 0,070 & 0,029 & 0,025 & 0,042 & 0,027 & 0,031 \\
\hline Mn & 0,005 & 0,002 & 0,002 & 0,001 & 0,001 & 0,004 & 0,001 & 0,003 & 0,004 & 0,002 & 0,006 & 0,005 & 0,008 & - & 0,001 & 0,001 \\
\hline $\mathrm{Mg}$ & - & - & - & 0,001 & 0,001 & - & 0,001 & - & - & - & - & - & 0,001 & - & 0,001 & - \\
\hline $\mathrm{Ca}$ & 0,002 & 0,002 & 0,001 & 0,001 & 0,001 & 0,001 & 0,003 & 0,001 & 0,001 & 0,002 & 0,002 & 0,002 & 0,001 & 0,001 & 0,006 & 0,009 \\
\hline $\mathrm{Ba}$ & 0,003 & 0,002 & 0,002 & 0,001 & 0,002 & 0,001 & 0,001 & 0,002 & 0,001 & 0,002 & 0,003 & 0,002 & 0,002 & 0,002 & 0,002 & 0,002 \\
\hline $\mathrm{Sr}$ & - & - & 0,001 & - & - & 0,001 & - & - & - & - & 0,001 & - & - & - & - & 0,002 \\
\hline $\mathrm{Na}$ & - & 0,003 & - & 0,003 & 0,002 & 0,004 & 0,001 & 0,004 & 0,001 & 0,003 & 0,003 & 0,002 & 0,002 & 0,002 & 0,001 & - \\
\hline $\mathrm{K}$ & - & - & - & - & - & - & - & 0,001 & - & - & - & - & - & - & - & 0,001 \\
\hline $\mathrm{P}$ & 0,026 & 0,030 & 0,020 & 0,030 & 0,032 & 0,038 & 0,034 & 0,038 & 0,033 & 0,026 & 0,038 & 0,022 & 0,018 & 0,037 & 0,043 & 0,064 \\
\hline $\mathrm{Nb}$ & 0,007 & 0,003 & 0,007 & 0,005 & 0,006 & 0,006 & 0,003 & 0,003 & 0,007 & 0,008 & 0,005 & 0,007 & 0,009 & 0,008 & 0,005 & 0,006 \\
\hline $\mathrm{La}$ & 0,001 & 0,001 & - & - & - & - & - & - & - & - & - & - & - & - & 0,002 & 0,001 \\
\hline $\mathrm{Ce}$ & - & - & - & - & - & - & - & - & - & - & - & 0,004 & 0,003 & - & 0,005 & - \\
\hline $\operatorname{Pr}$ & - & - & - & - & - & - & - & - & - & - & - & - & - & - & 0,001 & - \\
\hline $\mathrm{Nd}$ & 0,002 & - & - & - & - & - & - & - & - & - & - & 0,001 & - & - & 0,002 & 0,001 \\
\hline $\mathrm{Y}$ & - & - & - & - & - & - & - & - & - & - & - & - & - & - & - & - \\
\hline Cations & 1,017 & 1,023 & 1,015 & 1,021 & 1,023 & 1,024 & 1,021 & 1,026 & 1,019 & 1,020 & 1,030 & 1,018 & 1,018 & 1,022 & 1,025 & 1,031 \\
\hline
\end{tabular}


Análises WDS de Anatásio (III).

\begin{tabular}{|c|c|c|c|c|c|c|c|c|c|c|c|c|c|c|}
\hline Rocha & Beb. & Beb. & Beb. & Beb. & Beb. & Beb. & Beb. & Beb. & Beb. & Beb. & Beb. & Beb. & Beb. & Beb. \\
\hline Intemp. & Alot Base & Alot Base & Alot. Base & Alot Base & Alot Base & Alot Base & Alot Base & Alot Base & Alot Base & Alot Base & Alot Base & Alot Base & Alot Base & Alot Base \\
\hline Prof. (m) & 88,8 & 88,8 & 88,8 & 88,8 & 88,8 & 88,8 & 80,3 & 80,3 & 80,3 & 80,3 & 80,3 & 80,3 & 80,3 & 80,3 \\
\hline Análise & 24 & 29 & 30 & 31 & 32 & 33 & 118 & 120 & 121 & 142 & 143 & 146 & 147 & 148 \\
\hline $\mathrm{SiO}_{2}$ & 0,08 & 0,15 & 0,12 & 0,42 & 0,07 & 0,08 & 0,32 & 0,58 & 0,29 & 0,79 & 0,51 & 0,38 & 0,35 & 0,34 \\
\hline $\mathrm{TiO}_{2}$ & 83,22 & 78,79 & 82,41 & 82,73 & 71,57 & 87,86 & 87,75 & 86,21 & 86,01 & 91,43 & 93,68 & 87,05 & 90,22 & 93,07 \\
\hline $\mathrm{ZrO}_{2}$ & 0,43 & 0,10 & 0,40 & 0,11 & 0,15 & 0,10 & 0,19 & 0,25 & 0,07 & 0,08 & 0,11 & 0,14 & 0,18 & 0,28 \\
\hline $\mathrm{ThO}_{2}$ & 0,08 & n.d. & 0,02 & 0,04 & 0,06 & 0,09 & 0,01 & n.d. & 0,06 & 0,02 & n.d. & 0,02 & 0,07 & 0,05 \\
\hline $\mathrm{Al}_{2} \mathrm{O}_{3}$ & 4,88 & 6,31 & 4,82 & 2,38 & 9,91 & 4,08 & 1,97 & 1,18 & 1,70 & 0,08 & 0,07 & 1,85 & 0,53 & 0,36 \\
\hline $\mathrm{V}_{2} \mathrm{O}_{3}$ & 0,83 & 0,71 & 0,76 & 0,78 & 0,68 & 0,84 & 0,84 & 0,92 & 0,93 & 0,93 & 0,83 & 0,96 & 0,87 & 0,80 \\
\hline $\mathrm{Cr}_{2} \mathrm{O}_{3}$ & n.d. & 0,05 & n.d. & 0,02 & n.d. & n.d. & n.d. & 0,02 & 0,04 & n.d. & 0,04 & 0,04 & 0,03 & 0,04 \\
\hline $\mathrm{Fe}_{2} \mathrm{O}_{3}$ & 2,32 & 3,53 & 2,50 & 8,59 & 2,78 & 2,97 & 4,46 & 5,24 & 4,77 & 3,16 & 2,97 & 4,42 & 3,73 & 3,66 \\
\hline $\mathrm{MnO}$ & 0,07 & 0,24 & 0,42 & 0,21 & 0,14 & 0,07 & 0,07 & 0,10 & n.d. & 0,07 & 0,07 & 0,02 & 0,04 & 0,08 \\
\hline $\mathrm{MgO}$ & 0,01 & 0,05 & n.d. & 0,06 & 0,02 & 0,01 & n.d. & 0,01 & 0,01 & n.d. & 0,01 & n.d. & 0,04 & n.d. \\
\hline $\mathrm{CaO}$ & 0,14 & 0,42 & 0,19 & 0,18 & 1,08 & 0,07 & 0,07 & 0,04 & 0,05 & 0,12 & 0,13 & 0,05 & 0,05 & 0,09 \\
\hline $\mathrm{BaO}$ & 0,29 & 0,26 & 0,38 & 0,20 & 0,57 & 0,34 & 0,36 & 0,22 & 0,44 & 0,38 & 0,49 & 0,48 & 0,53 & 0,38 \\
\hline $\mathrm{SrO}$ & n.d. & 0,20 & n.d. & n.d. & 1,12 & 0,01 & 0,02 & n.d. & n.d. & 0,09 & n.d. & n.d. & n.d. & 0,07 \\
\hline $\mathrm{Na}_{2} \mathrm{O}$ & 0,11 & 0,07 & 0,09 & 0,09 & 0,03 & 0,13 & 0,04 & 0,09 & 0,04 & n.d. & n.d. & 0,01 & n.d. & 0,08 \\
\hline $\mathrm{K}_{2} \mathrm{O}$ & 0,01 & n.d. & n.d. & 0,01 & n.d. & 0,02 & 0,02 & n.d. & n.d. & 0,01 & n.d. & 0,02 & 0,01 & n.d. \\
\hline $\mathrm{P}_{2} \mathrm{O}_{5}$ & 3,07 & 5,02 & 3,15 & 2,74 & 9,16 & 2,60 & 1,89 & 1,13 & 1,91 & 0,01 & 0,13 & 1,78 & 0,56 & 0,38 \\
\hline $\mathrm{Nb}_{2} \mathrm{O}_{5}$ & 0,94 & 1,07 & 1,10 & 1,06 & 0,43 & 0,58 & 1,07 & 1,15 & 0,85 & 1,77 & 1,59 & 0,98 & 1,08 & 1,30 \\
\hline $\mathrm{La}_{2} \mathrm{O}_{3}$ & n.d. & 0,04 & 0,09 & n.d. & 0,01 & n.d. & n.d. & n.d. & n.d. & n.d. & 0,04 & n.d. & n.d. & n.d. \\
\hline $\mathrm{Ce}_{2} \mathrm{O}_{3}$ & 0,16 & 0,02 & 0,02 & n.d. & 0,20 & n.d. & n.d. & n.d. & n.d. & n.d. & 0,24 & n.d. & n.d. & n.d. \\
\hline $\mathrm{Pr}_{2} \mathrm{O}_{3}$ & n.d. & n.d. & 0,01 & 0,01 & 0,05 & n.d. & n.d. & 0,03 & n.d. & 0,05 & n.d. & 0,02 & n.d. & n.d. \\
\hline $\mathrm{Nd}_{2} \mathrm{O}_{3}$ & 0,08 & 0,01 & 0,02 & 0,08 & 0,26 & 0,05 & n.d. & n.d. & 0,05 & n.d. & n.d. & 0,01 & n.d. & n.d. \\
\hline $\mathrm{Y}_{2} \mathrm{O}_{3}$ & n.d. & n.d. & n.d. & n.d. & n.d. & n.d. & n.d. & n.d. & n.d. & n.d. & n.d. & n.d. & n.d. & n.d. \\
\hline TOTAL & 96,71 & 97,04 & 96,50 & 99,71 & 98,30 & 99,87 & 99,06 & 97,16 & 97,21 & 98,99 & 100,90 & 98,23 & 98,29 & 100,95 \\
\hline
\end{tabular}


Análises WDS de Anatásio (III) - continuação.

\begin{tabular}{|c|c|c|c|c|c|c|c|c|c|c|c|c|c|c|}
\hline Rocha & Beb. & Beb. & Beb. & Beb. & Beb. & Beb. & Beb. & Beb. & Beb. & Beb. & Beb. & Beb. & Beb. & Beb. \\
\hline Intemp. & Alot Base & Alot Base & Alot. Base & Alot Base & Alot Base & Alot Base & Alot Base & Alot Base & Alot Base & Alot Base & Alot Base & Alot Base & Alot Base & Alot Base \\
\hline Prof. (m) & 88,8 & 88,8 & 88,8 & 88,8 & 88,8 & 88,8 & 80,3 & 80,3 & 80,3 & 80,3 & 80,3 & 80,3 & 80,3 & 80,3 \\
\hline Análise & 24 & 29 & 30 & 31 & 32 & 33 & 118 & 120 & 121 & 142 & 143 & 146 & 147 & 148 \\
\hline $\mathrm{Si}$ & 0,001 & 0,002 & 0,002 & 0,006 & 0,001 & 0,001 & 0,004 & 0,008 & 0,004 & 0,011 & 0,007 & 0,005 & 0,005 & 0,004 \\
\hline $\mathrm{Ti}$ & 0,856 & 0,801 & 0,851 & 0,841 & 0,709 & 0,877 & 0,893 & 0,899 & 0,893 & 0,939 & 0,944 & 0,894 & 0,932 & 0,937 \\
\hline $\mathrm{Zr}$ & 0,003 & 0,001 & 0,003 & 0,001 & 0,001 & 0,001 & 0,001 & 0,002 & - & 0,001 & 0,001 & 0,001 & 0,001 & 0,002 \\
\hline Th & - & - & - & - & - & - & - & - & - & - & - & - & - & - \\
\hline $\mathrm{Al}$ & 0,079 & 0,101 & 0,078 & 0,038 & 0,154 & 0,064 & 0,031 & 0,019 & 0,028 & 0,001 & 0,001 & 0,030 & 0,009 & 0,006 \\
\hline V & 0,009 & 0,008 & 0,008 & 0,008 & 0,007 & 0,009 & 0,009 & 0,010 & 0,010 & 0,010 & 0,009 & 0,010 & 0,010 & 0,009 \\
\hline $\mathrm{Cr}$ & - & 0,001 & - & - & - & - & - & - & - & - & - & - & - & - \\
\hline $\mathrm{Fe}^{3}$ & 0,024 & 0,036 & 0,026 & 0,087 & 0,028 & 0,030 & 0,045 & 0,055 & 0,050 & 0,032 & 0,030 & 0,045 & 0,039 & 0,037 \\
\hline Mn & 0,001 & 0,003 & 0,005 & 0,002 & 0,002 & 0,001 & 0,001 & 0,001 & - & 0,001 & 0,001 & - & - & 0,001 \\
\hline $\mathrm{Mg}$ & - & 0,001 & - & 0,001 & - & - & - & - & - & - & - & - & 0,001 & - \\
\hline $\mathrm{Ca}$ & 0,002 & 0,006 & 0,003 & 0,003 & 0,015 & 0,001 & 0,001 & 0,001 & 0,001 & 0,002 & 0,002 & 0,001 & 0,001 & 0,001 \\
\hline $\mathrm{Ba}$ & 0,002 & 0,001 & 0,002 & 0,001 & 0,003 & 0,002 & 0,002 & 0,001 & 0,002 & 0,002 & 0,003 & 0,003 & 0,003 & 0,002 \\
\hline $\mathrm{Sr}$ & - & 0,002 & - & - & 0,009 & - & - & - & - & 0,001 & - & - & - & 0,001 \\
\hline $\mathrm{Na}$ & 0,003 & 0,002 & 0,002 & 0,002 & 0,001 & 0,003 & 0,001 & 0,002 & 0,001 & - & - & - & - & 0,002 \\
\hline $\mathrm{K}$ & - & - & - & - & - & - & - & - & - & - & - & - & - & - \\
\hline $\mathrm{P}$ & 0,036 & 0,057 & 0,037 & 0,031 & 0,102 & 0,029 & 0,022 & 0,013 & 0,022 & - & 0,001 & 0,021 & 0,007 & 0,004 \\
\hline $\mathrm{Nb}$ & 0,006 & 0,007 & 0,007 & 0,006 & 0,003 & 0,003 & 0,007 & 0,007 & 0,005 & 0,011 & 0,010 & 0,006 & 0,007 & 0,008 \\
\hline $\mathrm{La}$ & - & - & - & - & - & - & - & - & - & - & - & - & - & - \\
\hline $\mathrm{Ce}$ & 0,001 & - & - & - & 0,001 & - & - & - & - & - & 0,001 & - & - & - \\
\hline $\operatorname{Pr}$ & - & - & - & - & - & - & - & - & - & - & - & - & - & - \\
\hline $\mathrm{Nd}$ & - & - & - & - & 0,001 & - & - & - & - & - & - & - & - & - \\
\hline Y & - & - & - & - & - & - & - & - & - & - & - & - & - & - \\
\hline Cations & 1,022 & 1,028 & 1,024 & 1,029 & 1,037 & 1,022 & 1,017 & 1,019 & 1,017 & 1,011 & 1,010 & 1,017 & 1,013 & 1,014 \\
\hline
\end{tabular}

